UNIVERSIDADE DE SÃO PAULO

MUSEU DE ARQUEOLOGIA E ETNOLOGIA

PROGRAMA DE PÓS-GRADUAÇÃO EM ARQUEOLOGIA

Laércio Loiola Brochier

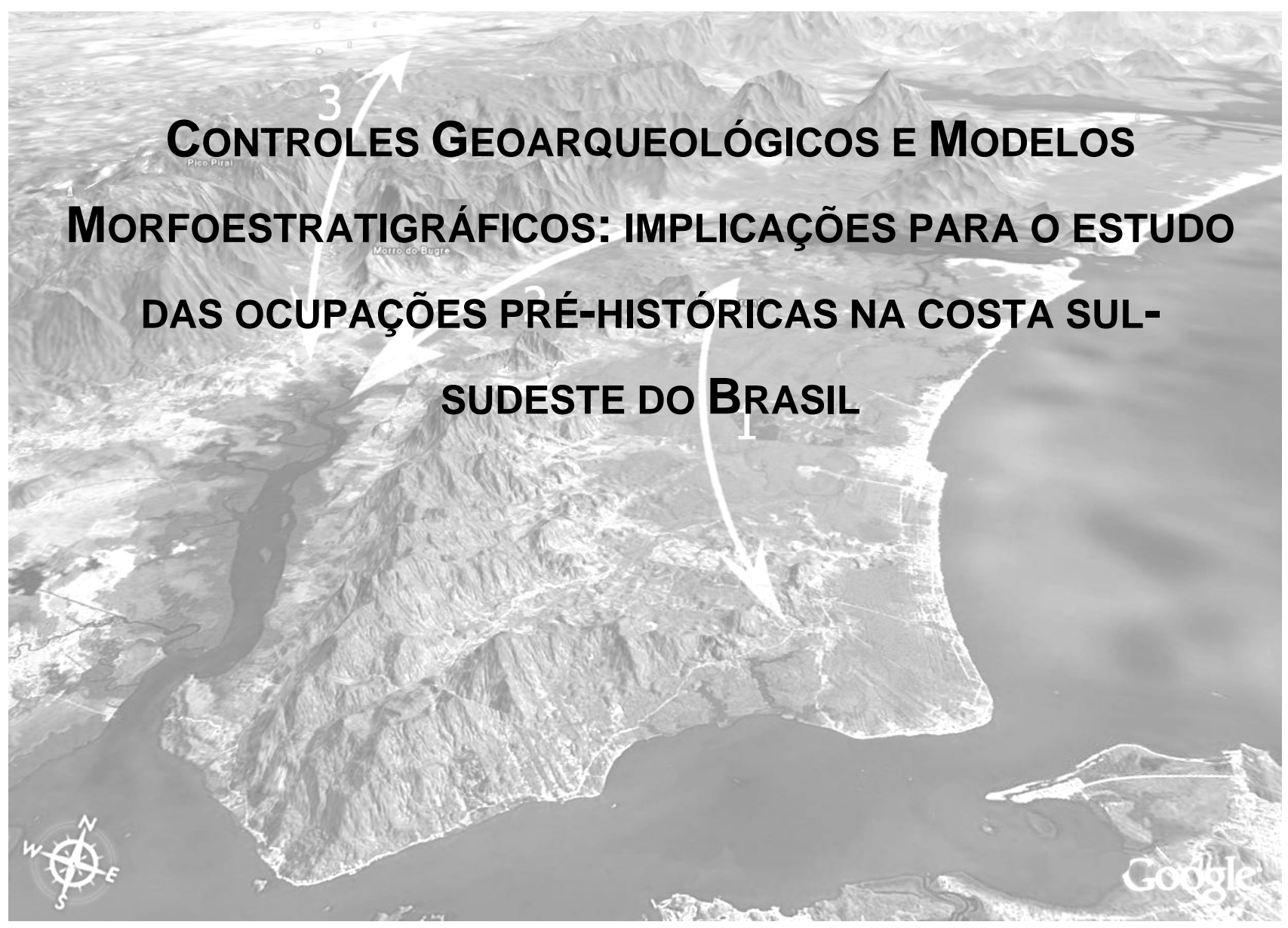

São Paulo 
UNIVERSIDADE DE SÃO PAULO

MUSEU DE ARQUEOLOGIA E ETNOLOGIA

PROGRAMA DE PÓS-GRADUAÇÃO EM ARQUEOLOGIA

\title{
CONTROLES GEOARQUEOLÓGICOS E MODELOS MORFOESTRATIGRÁFICOS: IMPLICAÇÕES PARA O ESTUDO DAS OCUPAÇÕES PRÉ-HISTÓRICAS NA COSTA SUL-SUDESTE DO BRASIL
}

\begin{abstract}
Tese apresentada ao Programa de PósGraduação em Arqueologia do Museu de Arqueologia e Etnologia da Universidade de São Paulo (MAE-USP), para obtenção do título de Doutor em Arqueologia.
\end{abstract}

Orientador: Prof ${ }^{\mathrm{a}}$. Dr ${ }^{\mathrm{a}}$. Marisa Coutinho Afonso

Linha de Pesquisa: Processos de formação do registro arqueológico

São Paulo 


\title{
Controles geoarqueológicos e modelos morfoestratigráficos: implicações para o estudo das ocupações pré-históricas na costa sul-sudeste do Brasil
}

\author{
Tese apresentada ao Programa de Pós- \\ Graduação em Arqueologia do Museu de \\ Arqueologia e Etnologia da Universidade de São \\ Paulo (MAE-USP), para obtenção do título de \\ Doutor em Arqueologia.
}

Aprovado em:

BANCA EXAMINADORA

Prof. Dr.

Instituição Ass.:

Prof. Dr.

Instituição Ass.:

Prof. Dr. Instituição Ass.:

Prof. Dr. Instituição Ass.:

Prof. Dr. Instituição Ass.: 
DEDICATÓRIA

Dedico este trabalbo primeiramente a Luana, minha filba, tão pequena ainda... mas capaz de mudar a maneira como vejo o mundo! À Tatiana, àquela pessoa que sempre esteve de braços abertos naqueles dias ensolarados e de manbãs de praia, e de braços afáveis naqueles dias nublados e de tardes vazias. Ao Tiburtius e a Brisa, companbeiros peludos nas madrugadas, seus paupites (miados) e criticas (arranbaram vários artigos) nunca foram desprezados. 


\section{AGRADECIMENTOS}

Durante o período de elaboração deste trabalho, tenho a agradecer a todos aqueles que direta ou indiretamente participaram desta caminhada representada não apenas pela tese, mas também pelas inúmeras vivências e convivências durante esta etapa. Certamente não será possível nomear todas as pessoas que me deram apoio e sugestões nas mais diferentes situações. Assim, neste contexto, destaco apenas genericamente os meus familiares, os amigos próximos e distantes,

Registro agora, os agradecimentos especiais a algumas pessoas e instituições que contribuíram decisivamente para a estruturação, continuidade e finalização desta pesquisa.

O primeiro reconhecimento e agradecimento direciona-se à $\operatorname{Prof}^{a}$. Dr ${ }^{a}$. Marisa Coutinho Afonso, orientadora desta tese, pelo suporte intelectual e pronto atendimento em todas as fases da tese. Pela excepcional capacidade de compreensão e versatilidade diante dos percalços e indecisões de um orientando pouco exemplar.

Gostaria de citar com destaque os professores doutores, Astolfo G.M.Araújo, Renato Kipnis e Paulo C. F. Giannini pelas importantes sugestões e apoio nos poucos contatos que tivemos. Ao prof Giannini agradeço ainda ao suporte técnico oferecido junto ao Laboratório de Sedimentologia do Instituto de Geociências-USP.

Ao Prof. Dr. Paulo César Soares, pelo pronto atendimento e disponibilidade do seu tempo no final do ano para ajustes e esclarecimentos sobre os métodos de análise de incertezas aplicados na tese. Também pela gentileza em ceder o uso dos programas em Turbo-basic Anfavim e Belim para as análises de probabilidade condicional e combinação de evidências.

Agradeço as arqueólogas Dra. Solange Caldarelli e Ms. Lucia Juliani e Ms. Maria do Carmo M Santos, pela possibilidade de realização dos estudos de diagnóstico e prospecção de sítios profundos junto a UTGCA-Petrobrás na planície costeira de Caraguatatuba. Agradeço ao apoio às hipóteses e propostas apresentadas naquela pesquisa, bem como, a todo a suporte técnico, logístico e financeiro, viabilizado através das empresas SCIENTIA e ALASCA.

Ao Museu de Arqueologia e Etnologia da Universidade de São Paulo, principalmente aos professores, pessoal da Secretaria Acadêmica, bibliotecários e funcionários, destacando-se em especial Vanusa S. Gregório, Geraldo S. Miranda, Eleuza Gouveia, Hélio Rosa Miranda. Especial agradecimento aos amigos Samuel Alves, Rafael Pedott, Paula Toth, Fernando e Daniella, Daniela Amaral, Rucirene Miguel, Ricardo Momma, Leandro e Lorena, Gilmar, Lucas Pires, 
Aos meus pais, Darci e Jurema, que estiveram presentes durante a fase final da tese, dando seu apoio incondicional e prestando ajuda e suporte nas várias demandas surgidas.

A Petrobrás S.A pela disponibilizarão das informações geradas nos projetos arqueológicos realizados na área da futura Unidade de Tratamento de Gás de Caraguatatuba (UTGCA) Ao Conselho Nacional de Desenvolvimento Científico e Tecnológico (CNPq) pela bolsa de doutorado, que muito contribuiu 


\section{RESUMO}

BROCHIER, L.L. Controles geoarqueológicos e modelos morfoestratigráficos: implicações para o estudo das ocupações pré-históricas na costa sul-sudeste do Brasil. 2009. 147p. Tese (Doutorado) - Museu de Arqueologia e Etnologia, Universidade de São Paulo, São Paulo, 2009.

A presente tese refere-se a uma proposta de abordagem geoarqueológica voltada ao estudo de sítios arqueológicos costeiros, enfocando pressupostos teóricos e metodológicos ligados à uma aproximação entre a Arqueologia, Geociências e Ciências da Informação. Objetivou em um primeiro momento, inserir questões e problemáticas relativas a necessidade de inclusão da incerteza no raciocínio e práticas arqueológicas, vislumbrando as possibilidades de seu tratamento. Neste sentido, a percepção do "problema da não informação" constituiu o argumento conceitual para a elaboração de um modelo de raciocínio dialético sobre a aquisição, geração, seleção e transmissão de informações na disciplina. Nessa perspectiva, sobreveio a necessidade da interação constante entre Teorias de Formação e de Recuperação, como passo essencial ao controle das perdas e ganhos informacionais e, ao tratamento das imperfeições, incompletudes, imprecisões e ambiguidades ligadas aos fenômenos arqueológicos e seu registro científico. Um dos aspectos explorados refere-se à percepção das incertezas e vieses envolvidos na interpretação das ocupações costeiras, notadamente quanto às problemáticas de origem e migração das primeiras populações nessas áreas. Em um modelo atual dicotômico entre o interior e o litoral, onde mesmo os sítios mais antigos (somente sambaquis) acham-se dispostos sobre a superfície dos terrenos, a percepção da dinâmica e complexidade dos sistemas costeiros, fica restrita ao enquadramento desses sítios em sucessões de "cenários" geomórficos e paeogeográficos. Deste modo, pouca atenção é dada às conseqüências de agentes dinâmicos sobre a configuração e seleção de sítios na atual paisagem costeira, bem como, à possibilidade de ocorrência e detecção de diferentes classes de sítios, que foram preservados em profundidade por meio de processos de capeamento sedimentar. Assim, em um segundo 
momento, foi proposto à utilização do conceito de "Controles Geoarquelógicos" (CG) no estudo e explicitação dos condicionantes naturais e analíticos envolvidos em uma pesquisa de caráter regional, cujo enfoque está nas relações informacionais estabelecidas entre sítios arqueológicos e meio (natural e analítico), e cujo resultado (síntese dialética) compreenderia a noção de evento arqueológico. Diante da explicitação da variabilidade envolvida na caracterização do Registro Arqueológico Regional (RAR), bem como, dos condicionantes complexos derivados da estrutura, dinâmica e evolução da paisagem, o evento arqueológico considerado na tese, compreendeu a investigação da probabilidade de preservação de sítios costeiros antigos (teoria de formação) e do seu potencial de detecção (teoria de recuperação). Neste sentido foi utilizado o raciocínio abdutivo para gerar hipóteses sobre a preservação ou não de sítios encobertos, tendo por base os modelos sedimentares e morfoestratigraficos produzidos para a costa sul-sudeste. Por sua vez, a busca de indicadores nas planícies costeiras de Guaratuba-PR e de Caraguatatuba -SP, possibilitou apontar condicionantes (variáveis) favoráveis a geração de um modelo de trapeamento de sítios (capeamento e preservação sedimentar) para a região da Baía de Guaratuba. Por fim, foi testado o raciocínio probabilístico Bayesiano e a Teoria de Evidências (Dempster-Shafer) para a inclusão e representação da incerteza na pesquisa de sambaquis, visualizando um método de tratamento das evidências e inferências geradas em sistemas baseados em conhecimento. Esses mesmos métodos também permitiram determinar os pesos para os diferentes indicadores, e as condições de necessidade, suficiência e ambigüidade das variáveis na geração de mapas aplicados à predição da favorabilidade e suscetibilidade de sítios arqueológicos enterrados na planície costeira de Guaratuba.

\section{PALAVRAS-CHAVE}

Geoarqueologia Costeira - Informação e Incerteza - Probabilidade Bayesiana - Modelos Morfoestratigráficos - Modelagem Preditiva - Sítios Arqueológicos enterrados 


\section{ABSTRACT}

BROCHIER, L.L. Geoarchaeological Controls and Morphostratigraphic Models: implications for the study of prehistoric occupation on the south-southeast coast Brazil. 2009. 147 f. Thesis (Doctor) - Museu de Arqueologia e Etnologia, Universidade de São Paulo, São Paulo, 2009.

This thesis refers to a proposal for a geoarchaeological approach focused on the study of coastal archaeological sites, concentrating on theoretical and methodological assumptions related to a closeness between the archeology, the Information Sciences and Geosciences. It aimed in a first moment, to insert issues and problems concerning the need for inclusion of uncertainty in archaeological reasoning and practice, foreseeing the possibilities of their treatment. In this sense, the perception of the "no information problem" was the argument for the conceptual development of a model of dialectical thinking about the acquisition, generation, selection and transmission of information in the discipline. Accordingly, the need for constant interaction between Formation and Recovery Theories became an essential step to the control of informational losses and gains, and the treatment of imperfections, incompleteness, inaccuracies and ambiguities relating to archaeological phenomena and their scientific record. One of the aspects exploited, is the perception of slants and uncertainties involved in the interpretation of coastal activities, notably on issues of origin and migration of the first people in those areas. In a current dichotomic model between the interior and the coast, where even the oldest sites (only sambaquis) are found placed on the surface of the land, the perception of the complexity and dynamics of the coastal systems, is restricted to the framework of these sites in a succession of geomorphic and paleogeographics "scenarios". Thus, little attention is given to the dynamic agents consequences on the configuration and selection of sites in the coastal landscape, and the possibility of occurrence and detection of different classes of sites, which were preserved indepth by a sedimental capstone process. Therefore, in a second moment, it was proposed to use the concept of "geoarchaeological control " (GC) in the study and explanation of natural and analytical conditions involved in a research of regional manner, whose focus is on the informational relations established between archaeological sites and the environment (natural and analytical), whose result (dialectical synthesis) understand the concept of the archaeological event. Given the explicit characterization of the variability involved in the Regional Archaeological Record (RAR), as well as the complex condition agent derived from the structure, dynamics and evolution of the landscape, the archaeological event considered in the thesis, understand the research of the probability of preservation of ancient coastal sites (formation theory) and its potential for detection (recovery theory). In this sense 
abdutive reasoning was used to generate hypotheses about the preservation or not of covered sites, based on the sedimentary and morphostratigraphic models produced for the south-southeast coast. In turn, the search for indicators in the coastal plains of GuaratubaPR and Caraguatatuba-SP, it made possible to point constraints (variables) favorable to the generation of a trap model for sites (sedimental capstone and preservation) for the region of Guaratuba Bay. Finally it was tested the probabilistic bayesian reasoning and Evidence Theory (Dempster-Shafer) for the inclusion and representation of uncertainty in the research of sambaquis foreseeing a method of treatment of the evidence and inferences generated by knowledge-based systems. These methods also allowed to determine the weights for different indicators, and the conditions of necessity, sufficiency and ambiguity of the variables in the generation of maps applied to the prediction of favorability and susceptibility of buried archaeological sites in the coastal plain of Guaratuba.

\section{KEY WORDS}

Coastal Geoarchaeology - Information and Uncertainty - Bayesian Probability Morphostratigraphic Models - Predictive modelling - Buried Archaeological Sites 


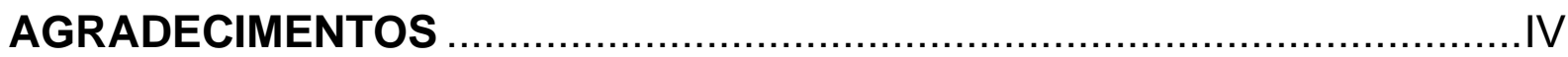

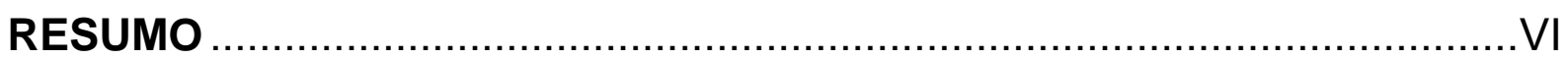

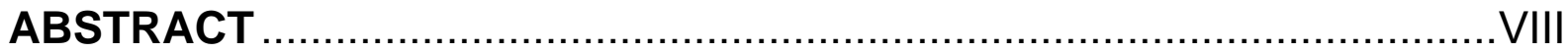

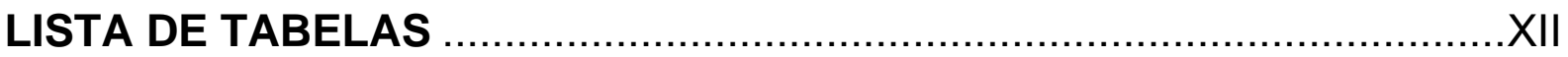

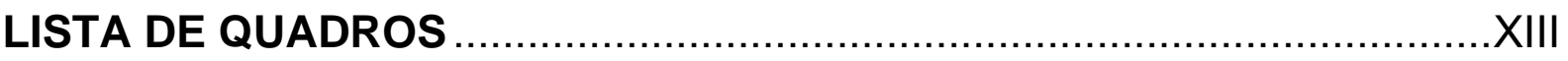

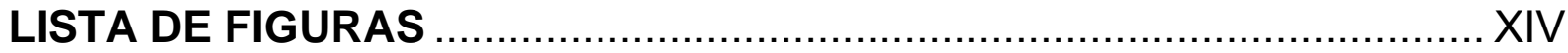

1 INTRODUÇÃO: DISCUSSÃO PRELIMINAR DOS ELEMENTOS

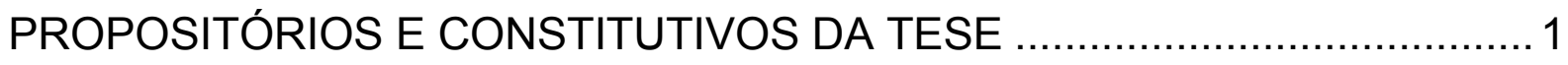

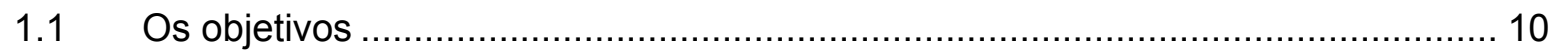

2 PRESSUPOSTOS PARA A ANÁLISE E TRATAMENTO DAS FONTES DE INFORMAÇÃO E INCERTEZA NO RACIOCÍNIO E PRÁTICAS

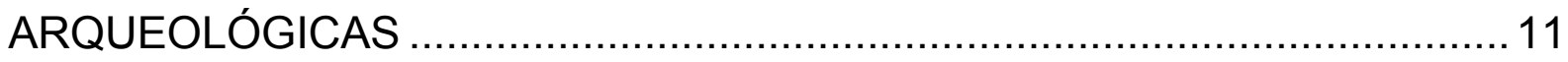

2.1 Incerteza e redundância em métodos científicos: bases para o entendimento dos processos informacionais ligados à produção de conhecimento.

2.2 A percepção da Teoria Informacional no pensamento e inferências arqueológicas 26

2.3 O problema da "Não-Informação": Proposta para a análise e tratamento da incerteza em Arqueologia

2.3.1 Relações formais entre evidências e inferências: os condicionantes do raciocínio probabilístico na análise de incerteza

3 INFORMAÇÃO E INCERTEZA NOS MODELOS DE INFERÊNCIA SOBRE A OCUPAÇÃO COSTEIRA NO BRASIL

4 CONTROLES GEOARQUEOLÓGICOS: UMA PROPOSTA PARA O REGISTRO ARQUEOLÓGICO REGIONAL ......................................... 53

4.1 Controles Geoarqueológicos: Conceito e Modelo geral

5.1 Área da Baía de Guaratuba: controles e corredores no estudo da espacialidade de sambaquis. 
5.2 Aspectos gerais e o levantamento de sambaquis na Baia de Guaratuba 79

5.2.1 Histórico das principais pesquisas de enfoque geoarqueológico e geológicoevolutivos; 79

5.3 A dinâmica sedimentar e evolutiva em Caraguatatuba: Um caso de controle em zonas de trapeamento

5.3.1 A Pesquisa de processos evolutivos e sítios profundos em Caraguatatuba ..... 85

6 A MODELAGEM DA INFORMAÇÃO E INCERTEZA NA GERAÇÃO DE UM MODELO DE FAVORABILIDADE DE SÍTIOS PROFUNDOS NA PLANÍCIE COSTEIRA DE GUARATUBA. 98

6.1 A aplicação do raciocínio probabilistico Bayesiano na geração de um modelo de favorabilidade de sítios encobertos na planície costeira de Guaratuba. 101

6.1.1 Pressupostos e descrição do Método .................................................... 101

6.1.2 Técnicas utilizadas e seleção dos indicadores .......................................... 105

6.1.3 Determinação dos pesos e aplicação do modelo probabilístico ...................... 111

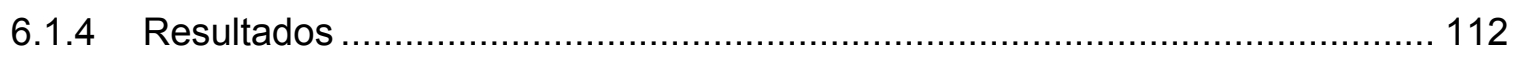

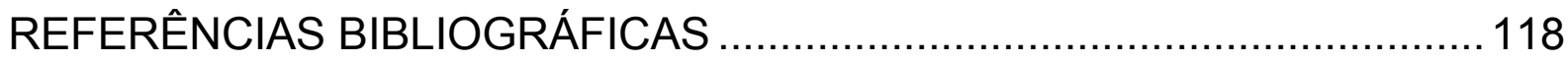

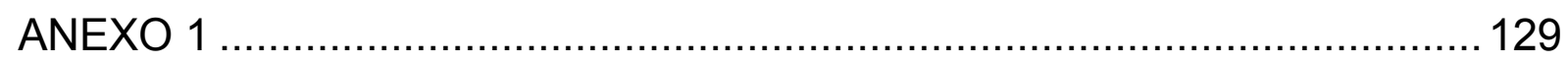

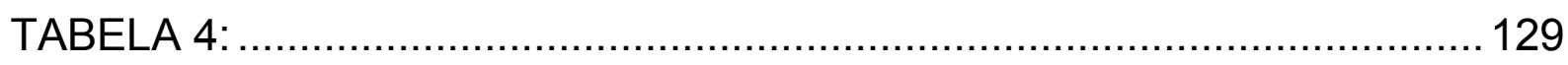




\section{LISTA DE TABELAS}

Tabela 1: Exemplo de tabela contendo o diagnóstico de casos conhecidos ou desconhecidos por cela, com quatro colunas; a quarta é se a ocorrência (o evento

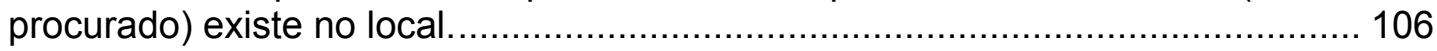

Tabela 2: Exemplo da construção da segunda planilha contendo o diagnóstico espacial dos diferentes indicadores por cela 107

Tabela 3.

Tabela 4: 


\section{LISTA DE QUADROS}

Quadro 1: Alternativas de ênfase à questão "Por que Adão comeu a maçã?" em uma análise vinculada ao modelo pragmático de explicação (adaptado de Dutra, 2003:127): ... 17

Quadro 2: Representação das 9 premissas (Regras) entre $\mathrm{S}$ e $\mathrm{P}$ e as avaliações de confiabilidade (c), negação (n)e ambigüidade (a) da Relação tipo "S então P" (constituindo 27 premissas menores)

Quadro 3: Datações de sambaquis no Litoral Paranaense

Quadro 4: Dados relativos a datações de C14 na Planície Costeira de Caraguatatuba...... 90

Quadro 5: Definições gerais e exemplos das condições de necessidade e suficiência da variáveis (fonte: Soares et al., 2002, adaptado)

Quadro 6 


\section{LISTA DE FIGURAS}

Figura 1: Aspecto da faixa de depleção do reservatório do Capivari-Cachoeira, no Estado do Paraná. A prospecção em suas margens traz consigo inúmeros condicionantes que podem alterar a interpretação sobre a distribuição dos vestígios encontrados em suas margens (fonte: Google Earth)............................................................. 5

Figura 2: Freqüências das letras na língua portuguesa, cujas seqüências não são completamente aleatórias, tendo portanto, uma estrutura estatística. (retirado de FERNANDES e AZEVEDO, 2006:5)

Figura 3: Diagrama representando os diferentes níveis de informação do registro arqueológico e suas relações gerais de perdas e ganhos informacionais (fonte: Araújo,1999, adaptado de Sullivan, 1978)......

Figura 4: Esquema proposto para o enquadramento dos processos de transmissão de informações no raciocínio arqueológico

Figura 5: Possíveis relações entre evidência e objeto (proposição) e condicionamentos de raciocínio por silogismo, conforme Soares (2000, adaptado). No diagrama Venn acima: quadrado = espaço probabilístico; circunferência cinza = espaço onde o objeto está presente $(P)$ e; cincunferência hachurada= espaço onde a evidência está presente.

Figura 6: Área de ocorrência de sítios costeiros incluindo as barreiras representadas pelas serras e, os vales ou áreas interioranas onde foram identicados zoólitos fora dos sambaquis (fonte: PROUS, 1992)

Figura 7: Principais fatores ligados a estrutura, dinâmica e evolução das paisagens geoecológicas envolvidos na determinação de Controles Geoarqueológicos.

Figura 8: Principais relações informacionais investigadas no estudo dos processos geológicos-sedimentares ligados à caracterização do registro arqueológico em ambientes dinâmicos.

Figura 9:Disposição das baías de Babitonga, Guaratuba e Paranaguá, entre o estado do Paraná e norte de Santa Catarina (fonte: Google, 2005).

Figura 10:Tipos de substratos e posicionamento de sambaquis indicados para a costa sul sudeste brasileira (fonte: Fairbridge, 1976, modificado por Suguio et al., 2005)..... 68

Figura 11:Mapa simplificado da planície costeira ente a Baía de Guaratuba e a Baía da Babitonga, com ênfase nas possível rota do Eixo São João/Palmital para o deslocamento de populações sambaquianas em os respectivos complexos estuarinos (retirado de OLIVEIRA e HORN FILHO, 2001, p.69).

Figura 12: À esquerda: modelo da configuração paleogeográfica da planície costeira de Itapoá durante o máximo da transgressão holocênica - (1) rochas do embasamento e depósitos continentais indiferenciados; (2) terraços pleistocênicos; (3) barreira transgressiva e esporões holocênicos 4 - estuários e lagunas. À direita e detalhe à esquerda: Mapa geológico - (1) terraço marinho, praias e dunas holocênicos; (2) planícies paleoestuarinas e mangues holocênicos; (3) terraços pleistocênicos; (4) leques, terraços e planícies aluviais, colúvios; (5) sedimentos terciários (Mina Velha); (6) embasamento cristalino; (conforme (SOUZA et al., 2001, adaptado) ... 71 
Figura 13:Visualização das alternativas de rotas de deslocamento costeiro entre as baías da Guaratuba e Babitonga. 1) Corredor de Itapoá; 2) Eixo São João-Palmital e 3) Corredor Garuva.

Figura 14:Bloco diagrama ilustrando cinco contextos ambientais e deposicionais associados a sítios arqueológicos hipotéticos em um sistema de barreira-laguna na área costeira de Delaware (conforme KRAFT et al, 1983). Neste esquema, os triangulos de 1 a 5 correspondem a sítios dispostos em diferentes locais fisiográficos. Os triângulos de 1' a 5', por sua vez, representam os mesmos locais em subsuperficie, com a posição dos sítios após a elevação do n.r.m, em associação com a dinâmica erosivo-deposicional costeira.

Figura 15:Comparação do modelo de identificação de sítios arqueológicos em paleocanais capeados (Waters, 1992) e do perfil estratigráfico transversal ao eixo do estuário de Paranaguá (Lessa et al. Apud Soares et al, 1997, adaptado). Esta área parece apresentar condições propícias à detecção de sítios submersos e capeados. 75

Figura 16: Correlação entre perfis batimétricos da plataforma costeira sul e sudeste com a curva de variações dos paleoníveis marinhos. (fonte CORRÊA, 1996, adaptado de figuras apresentadas por SUGUIO et al, 2005).

Figura 17:Disposição de leques e cones aluviais ao longo do litoral do Paraná (fonte BESSA, 1997)

Figura 18:Disposição do leque aluvial do rio Cubatão e o posicionamento de sambaquis georreferenciados na área da baía de Guaratuba.

Figura 19: Abrangência do leque aluvial do Cubatão e seus diferentes ciclos de migração de meandros.

Figura 20

Figura 21: Mapa de distribuição dos depósitos quaternários na planície costeira do estado de São Paulo e a localização da planície costeira de Caraguatatuba, no local previsto para a futura instalação da UTGCA/Petrobrás.

Figura 22: Mapa de Iso-espessura do depósito da corrida de detritos de 1967, na área da planície de Caraguatatuba, em local previsto para a instalação da UTGCA/Petrobrás (área 4A) (fonte: IPT, 2006, adaptado).

Figura 23: Modelo de perfil morfoestratigráfico elaborado por MARTIN; SUGUIO (1978), tendo por base aquele produzido por FÚLFARO et al. (1976)

Figura 24: Proposta de prospecção subsuperficial. Sondagens de $4 \mathrm{~m}$ de profundidade (faixa de entorno); sondagens de $7 \mathrm{~m}$ de distribuídas na área útil (com atenção para as faixas "a" e "b" de entorno do aterro); e as sondagens de $20 \mathrm{~m}$ de profundidade (faixa mais escura). (Fonte: Scientia, 2007)

Figura 25:Modelo em forma de bloco diagrama indicando as diferentes situações estimadas para a localização de sítios encobertos na Baía de Guaratuba

Figura 26:Área piloto onde será desenvolvido o modelo preditivo com a numeração das celas de observação $(1 \mathrm{~km} \times 1 \mathrm{~km})$ 
Figura 27:Área piloto onde será desenvolvido o modelo preditivo com a numeração das celas de observação $(1 \mathrm{~km} \times 1 \mathrm{~km})$

Figura 28:Área piloto onde será desenvolvido o modelo preditivo com a numeração das celas de observação $(1 \mathrm{~km} \times 1 \mathrm{~km})$

Figura 29:Representação empírica das condições de necessidade (a) e suficiência (b), com os símbolos representando os eventos e áreas rachuradas a distribuição da variável (indicador) considerada 111

Figura 30 116

Figura 31 117 


\section{INTRODUÇÃO: DISCUSSÃO PRELIMINAR DOS ELEMENTOS PROPOSITÓRIOS E CONSTITUTIVOS DA TESE}

As perspectivas iniciais desenvolvidas no âmbito da presente tese compreenderam questões levantadas em alguns estudos anteriormente realizados pelo autor, cujas propostas permearam problemas metodológicos e interpretativos associados ao que poderia ser chamado de princípios de "abordagem informacional" em Arqueologia. Esses estudos inserem-se em problemáticas ligadas à geração e análise de informações e evidências arqueológicas em escalas amplas (regionais a subregionais), em ambientes de grande diversidade compartimental (aspectos fisiográficos, ambientais, uso do solo, etc) e, cujas paisagens foram e estão sendo afetadas por processos morfodinâmicos, evolutivos e tecnogênicos (ação humana).

No contexto acima estavam, por exemplo, os trabalhos ligados ao diagnóstico arqueológico para Planos de Manejo em Unidades de Conservação - UCs (tais como, Parques Nacionais, Áreas de Proteção Ambiental, Reservas, etc), tema de mestrado do autor (BROCHIER, 2004), onde foram apontadas algumas perspectivas metodológicas para o uso de métodos oportunísticos de análise. Destaca-se a percepção sobre os problemas de tendências (vieses) informacionais ligadas a este tipo de estratégia em um levantamento regional, que conforme SCHIFFER (1987, p. 236) recaem especialmente sobre dois componentes associados à probabilidade de descoberta de artefatos ou sítios: a visibilidade e a acessibilidade. Apesar desses métodos serem por vezes considerados "methodologically unlovely" (SCHIFFER et al., 1978, p. 2), foi proposto o uso de controles sobre os fatores geradores de tendência no registro e diagnóstico de áreas e sítios, de modo que as feições de visibilidade e acessibilidade foram utilizadas explicitamente para responder a problemas específicos (indicar as principais fragilidades e potencialidades arqueológicas) ${ }^{1}$, em

\footnotetext{
${ }^{1}$ Conforme Brochier, op cit, p.39: “(...) ambos os termos podem se inter-relacionar quando enfocados numa proposta metodológica que tenha por base a inclusão explicita desses componentes no levantamento arqueológico. Ou seja, que uniria estratégias técnicas de visibilidade (determinando o "alcance ou capacidade de observação") e estratégias logísticas de acessibilidade (determinando as formas de "mobilidade ou intercurso do observador"). Desta forma admite-se que a visibilidade e a acessibilidade são fatores interdependentes, que interagem freqüentemente entre o observador e o observado em um levantamento regional, notadamente quando se usam técnicas oportunísticas de detecção. A influência desses componentes pode ser negativa, quando não identificada ou não explicitada no âmbito dos trabalhos, gerando conseqüentemente tendências no RAR. Entretanto também poderá ser positiva, desde que seja explicitamente incluída como elemento de análise prospectiva, gerando controle sobre esses fatores no RAR. Por exemplo, um sítio identificado em um barranco de estrada remete a condições de acesso e observação apropriadas para um futuro uso educativo ou turístico. Por sua vez, o fato de estar visível e perturbado por um processo antrópico (a construção da estrada), determina condições de risco e medidas específicas de gestão. Se o objetivo
} 
contextos específicos (propósitos de criação das UCs, diretivas de manejo, preeminência de ações conservacionistas e públicas). Naquela situação, portanto, os estudos não objetivavam necessariamente a geração de parâmetros interpretativos regionais:

O uso de controles sobre fatores geradores de tendências também foi vislumbrada em Avaliações de Impacto Ambiental (AIA), onde devido à eminência de perda de bens e informações culturais, exige-se que os levantamentos tenham a capacidade de "identificar e amostrar todas as categorias de recursos arqueológicos de uma área determinada" (CALDARELLI; SANTOS M., 1999-2000, p. 59).

Assim, no caso dos levantamentos das Estações de Tratamento de Matinhos e Pontal no Litoral Paranaense (LACTEC/CEHPAR, 2001) esboçou-se uma tentativa de aliar os métodos sistemáticos e oportunísticos, selecionando alguns fatores de visibilidade e acessibilidade como elementos de "amostragem" arqueológica, o que permitiu uma análise com certa cobertura estatística, reduzindo os vieses no diagnóstico (levantamento, prospecção, avaliação) e nas interpretações (verificação de ocorrências/padrões, significâncias e potencialidades). Neste sentido foram detalhadas todas as feições de exposição de solos existentes (indicando extensão, direção, variações de profundidade, compartimento paisagístico, etc), escolhendo aquelas que propiciassem melhor cobertura, e analisando sua influência e capacidade de incorporação na varredura sistemática de modo a diagnosticar "presenças" e "ausências". Entretanto, ficou clara a dificuldade de integração e tratamento dos dados gerados por ambos os métodos quando o objetivo é a geração de parâmetros representativos e comparativos para o Registro Arqueológico Regional (RAR).

Algumas das problemáticas associadas aos estudos acima foram novamente verificadas no levantamento arqueológico para o Zoneamento Ecológico-Econômico e Plano de Manejo na Baía de Guaratuba (APA GUARATUBA, 2002). Nesta pesquisa foram avaliados 73 sítios arqueológicos (a maior parte sambaquis), sob critérios exclusivamente oportunísticos, levantando aspectos de fragilidades e potencialidades associadas ao registro. A percepção da incidência de fatores morfodinâmicos sobre sítios, verificados em um ambiente tido como "de baixa energia", propiciou indagar sobre algumas incertezas derivadas da relação sítios versus meio e desta relação com o domínio investigativo (espaço amostral ou probabilístico delimitado de forma explícita ou não, pelas ferramentas analíticas e inferenciais).

No primeiro caso (sítio versus meio) a identificação de processos erosivos e deposicionais afetando sítios antigos e recentes (sambaquis, históricos, etc) suscitaram questionamentos sobre incidência desses processos no passado e sua influência na interpretação das

da pesquisa é de levantar esses tipos de potencialidades e fragilidades, o melhor método deve basear-se na visibilidade e acessibilidade dos recursos." 
presenças e ausências indicativas de "padrões" ou "preferências". Como exemplo, processos deposicionais associados à presença de um extenso leque aluvial na área interna da baia de Guaratuba, implicou no capeamento sedimentar de um dos sambaquis detectados; por sua vez, neste mesmo compartimento foi verificada a incidência de processos erosivos significativos associados a migrações de meandros e canais de maré, Ou seja, a ocorrência de fenômenos similares no passado (sem considerar ainda, as variações no nível relativo do mar) certamente teria afetado determinados estratos ambientais e os sítios neles inseridos, criando certos condicionantes geológicos subjacente aos fatores culturais envolvidos.

No segundo caso (sítios-meio versus domínio de investigação) certos condicionantes e incertezas na interpretação das evidências são geradas pela própria delimitação de um espaço amostral e de uma escala de investigação independentemente dos fatores culturais associados a formação do sítios, ou do método prospectivo. Assim, a averiguação do alcance dos métodos oportunísticos em levantamentos regionais levou também a uma maior percepção das limitações dos métodos ditos "mais científicos" ou de base estatística, já que os mesmos também estão sujeitos a condicionamentos geradores de tendências e incertezas. Assim, não basta à adoção de métodos densos de cobertura, se não forem observados, por exemplo, os processos subjacentes à formação de sítios em áreas dinâmicas, mas também, os processos ligados recuperação das informações diante de diferentes contextos. Neste sentido, a adoção de um limite qualquer, natural ou artificial, estabelecido como área de investigação, irá condicionar determinadas inferências, como na caracterização das representatividades espaciais, temporais e contextuais dos compartimentos ambientais versus registro. A influência do entorno e dos limites estabelecidos pela pesquisa, ainda que evidente em muitos casos, raramente é considerada como capaz de agregar incertezas e vieses informacionais, e prejudicar a consistência das evidências e das inferências estabelecidas no processo analítico.

Sem o conhecimento das relações contextuais e informativas subjacentes à análise de nossa "malha investigativa", não temos como saber se alguns dos padrões observados ou inferidos (incluindo aqueles gerados por técnicas avançadas de mineração de dados) resultam da ação humana, ou de condicionantes derivados de fatores naturais ou tecnogênicos. Como exemplo, não podemos advogar uma maior representatividade de sítios líticos em topos de colinas e cerâmicos em terraços fluviais, se não tivermos uma noção da representatividade espacial e cronológica dessas feições, ou ainda, se na evolução geomórfica da paisagem tais feições responderam de forma seletiva na preservação e configuração de sítios. A interconexão entre sítios-meio-domínio também é evidente quando verificamos as diferentes formas de interpretação de um sítio lítico, por exemplo, quando variamos as possíveis opções de disponibilidade (incluindo ausência) e as distâncias das 
fontes de matéria prima lítica do entorno (dentro e fora do domínio amostral). Se o meio é essencial à interpretação do sítio, e se o sítio é considerado um elemento de inferência, conceitualmente este não poderia ser tratado ou delimitado de forma dicotômica em relação a aquele.

Uma situação comum em levantamentos arqueológicos regionais onde se verifica a complexidade da inter-relação informacional entre sítios, limites investigativos e entorno, refere-se à perspectiva metodológica de implantação de transects. A proposição geral considera este método de investigação como capaz de cobrir "estratos paisagísticos diferenciados" esperando que a variabilidade de ambientes percorridos se traduza em uma avaliação amostral da variabilidade dos sítios e dos padrões locacionais existentes. Entretanto, estratos paisagísticos diferenciados podem apresentar condições de exposição ou capeamento de solos diferenciados, o que poderá traduzir-se em uma maior percepção de certas áreas em relação a outras. Por sua vez, a não explicitação de qual a porcentagem de estratos paisagísticos percorridos implica na geração de outro tipo de viés na recuperação de informações, e que poderá impossibilitar a comparação com outros transects ou levantamentos "areais" realizados nas proximidades. Por fim, estratos considerados homogêneos em uma escala de análise podem não apresentar homogeneidade interna nem similaridade com outros estratos, quando observados sob contextos mais amplos (de menor resolução) ou mais restritos (de maior resolução) que a escala considerada.

Outro exemplo que ilustra as problemáticas existentes na recuperação, análise e tratamento de informações arqueológicas em contexto espacial e dinâmico específico, compreende alguns estudos prospectivos realizados sobre faixas de depleção de reservatórios artificiais (BROCHIER e MIGUEL, 2001; SCIENTIA, 2004). Os levantamentos neste tipo particular de ambiente (como no reservatório do Capivari-Cachoeira-PR, visualizado na Figura 1), apesar de revelarem grande número de vestígios e sítios arqueológicos, mostraram-se extremamente complexos quando observados em termos da aplicação de abordagens analíticas e interpretativas sobre o RAR. 


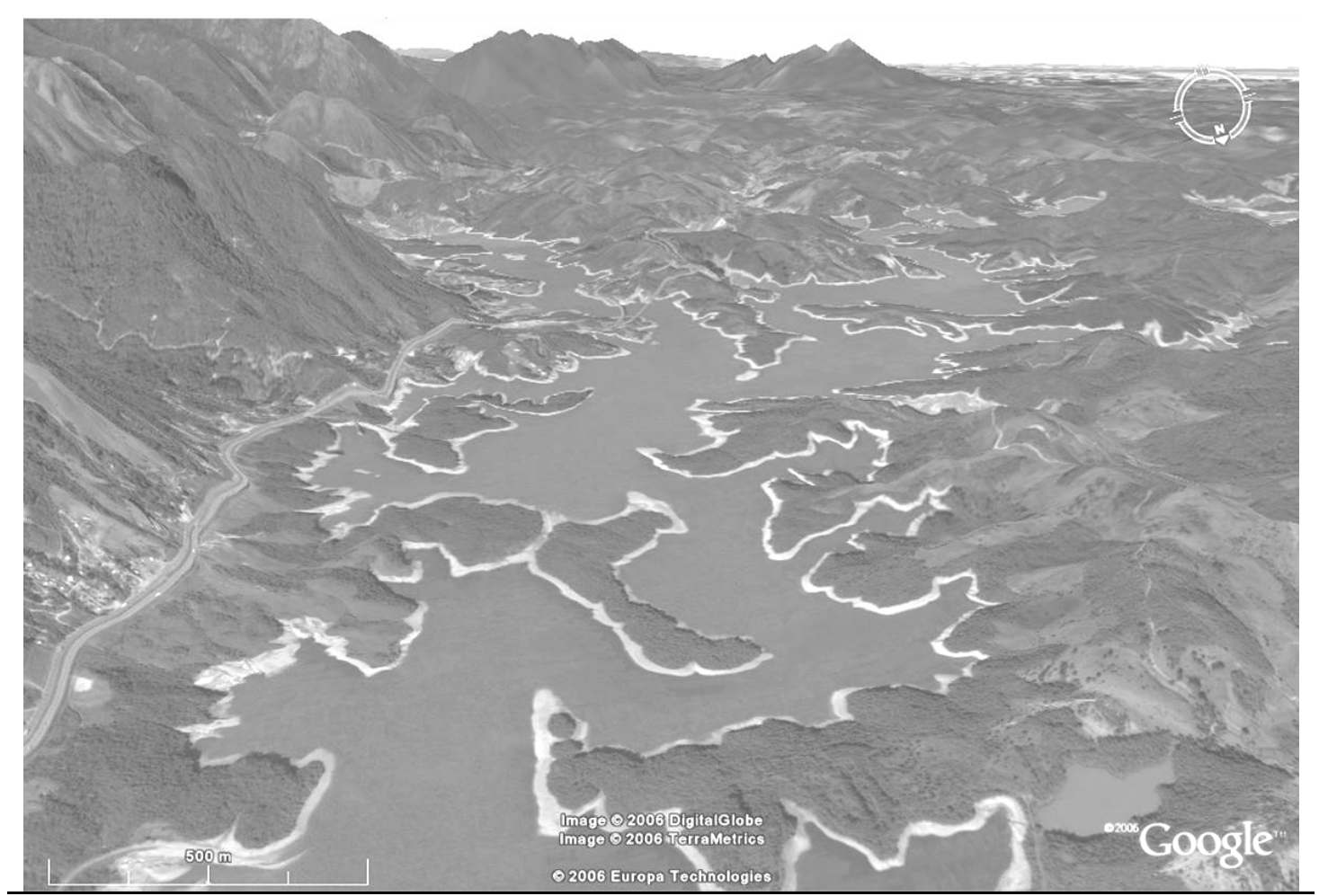

Figura 1: Aspecto da faixa de depleção do reservatório do Capivari-Cachoeira, no Estado do Paraná. A prospecção em suas margens traz consigo inúmeros condicionantes que podem alterar a interpretação sobre a distribuição dos vestígios encontrados em suas margens (fonte: Google Earth).

As técnicas tradicionais probabilísticas ou oportunísticas não poderiam ser utilizadas sem um rigoroso estudo dos componentes estruturais e processos dinâmicos existentes, já que os mesmos traziam consigo inúmeras variáveis, a começar pela "escolha de uma faixa altimétrica" de investigação (diferente, portanto, dos levantamentos areais ou tipo transect). Como neste tipo de estudo as tendências ligadas à visibilidade e acessibilidade puderam ser praticamente desprezadas (em geral as margens estão bem expostas e de fácil acesso por embarcação), o enfoque recaiu principalmente sobre outras questões que pudessem interferir na interpretação do registro e na identificação de parâmetros regionais de ocupação. Algumas das variáveis identificadas foram as seguintes:

- A área de prospecção e estudo corresponde a uma faixa de prospecção variável, situada entre cotas altimétricas delimitadas pela variação do nível d'água (deplecionamento) nas margens de reservatórios. Assim, dependendo das condições pluviométricas anuais e das condicionantes de operação do reservatório (taxas de vazões), as áreas ou os perímetros marginais a serem pesquisados sofrerão alterações, conforme o período estipulado para a realização dos trabalhos.

- As dimensões do represamento de jusante à montante alteram a relação de distâncias entre suas margens, bem como a altura relativa com o antigo nível de base (no caso, a calha dos principais rios formadores da represa). Desta forma, e genericamente, sítios arqueológicos identificados à jusante situam-se em posições 
geralmente mais distantes do rio principal, tanto horizontalmente quanto verticalmente. Por sua vez, sítios identificados nas margens à montante estarão mais próximos (horizontal e verticalmente) desse nível de base. Esta relação também é alterada pelas características do relevo pré-existente, que condiciona a própria forma do reservatório ("corpo" e "braços").

- A ocorrência de uma maior percentagem de ambientes de vertentes nas margens expostas pode produzir um viés na representatividade geral dos registros. Da mesma maneira, qualquer variação na escala de análise seja em termos restritos (ex. análise de feições mínimas de relevo ${ }^{2}$ ) seja em termos mais amplos (contexto da paisagem de entorno em ambas as margens) introduz novos componentes com potencial para gerar novas interpretações sobre a representatividade do registro;

- Para o caso de uma abordagem sistemática, esta compreenderia, por exemplo, a delimitação percentual e distribuição regular de faixas perimetrais ao longo do reservatório. Entretanto, uma mesma extensão linear de margens prospectadas, em geral, não corresponde a uma igualdade de áreas percorridas $\left(\mathrm{m}^{2}\right)$. As diferenças de declividade nas encostas alteram substancialmente a extensão lateral (largura) da faixa de depleção, o que altera a relação percentual do levantamento.

- O método de prospecção em faixa de depleção também não apresenta correspondência com abordagens do tipo transect, pois estas têm caráter linear e são estabelecidas de forma a percorrer áreas com diversidade topográfica. No caso das margens de represas, as faixas de pesquisa poderão ser lineares, convexas ou côncavas, e sua variabilidade altimétrica está restrita apenas às cotas de deplecionamento dos reservatórios (equivalendo a um levantamento efetuado em determinada variação de curva de nível). A diversidade topográfica e ambiental compreende a segmentação de diferentes contextos de encostas, interflúvios e fundos de vales em uma mesma bacia hidrográfica, com variações de altura em relação aos antigos níveis de base locais;

- Os materiais arqueológicos estão sujeitos a processos subaquáticos e subaéreos contínuos, que podem alterar a qualidade e a quantidade de vestígios e estruturas, bem como a própria distribuição espacial de ocorrências na área. Alguns fenômenos gerais apresentam conseqüências diretas sobre registros arqueológicos situados na faixa de depleção, tais como a supressão da vegetação e a denudação dos horizontes pedológicos superficiais; a aceleração da meteorização ou intemperismo devido à

\footnotetext{
${ }^{2}$ Conforme COLANGELO $(1989 ; 1986)$
} 
variação no nível d'água; a ação de agentes bióticos; processos físico-químicos e climáticos (orografia, variação térmica, evaporação, condensação, diminuição de coeficiente de atrito, permeabilidade, compactação, etc); a ação cinética pluvial (formação de crosta, escoamento laminar e linear) e suas feições erosivas (sulcos, calhas, ravinas, voçorocas); os movimentos gravitacionais (rastejamentos, fluxos, escorregamentos translacionais e rotacionais, queda de blocos e detritos, etc.); os processos fluviais/eólicos (correntes, formação de ondas, reentalhe de leitos, erosão remontante, transporte, abrasão) e antrópicos (marolas de embarcações, pisoteamento, criação de gado, trapiches, etc.), entre outros;

Uma das questões a serem consideradas nos casos acima, refere-se ao desconhecimento do grau de interconexão e da variabilidade das relações sítio-meio-domínio investigativo, bem como, daqueles indicadores capazes de permitir inferências mais seguras sobre o RAR. Por sua vez, mesmo conhecendo todas variáveis envolvidas em seu domínio de investigação, a falta de explicitação dessas variáveis pode inviabilizar a correlação dos padrões observados com outras áreas, principalmente se ocorrem variações nos métodos de investigação. Quanto ocorre a explicitação, temos como verificar quais as informações foram selecionadas em um rol de informações possíveis, e então, verificar "o que foi deixado".

Para finalizar esta primeira linha propositória, temos o problema da existência de fontes inerentes de incerteza, visto que a arqueologia é uma ciência que lida com conjuntos de informações fragmentadas do passado, contidas ou interceptadas por conjuntos de informações selecionadas no presente, e ambas, compondo subconjuntos de um determinado espaço amostral cujo universo é desconhecido. Outro aspecto refere-se ao fato de que os tipos de problemas a serem respondidos em Arqueologia necessitam de "contextos" para serem plenamente elucidados, e contextos nada mais são que relações informacionais, que dependem de associações/correlações circunstanciais segundo uma estrutura de raciocínio. Fica claro que certas conclusões (fatos, inferências) em Arqueologia são válidas apenas para determinados contextos e escalas (STEIN, 1993), havendo situações inerentes de ambiguidade e conflito entre as evidências e proposições.

Os exemplos e conjecturas apontadas acima suportam o pressuposto defendido nesta tese, de que devemos considerar e incorporar as complexidades e incertezas inerentes ao tipo de informação que utilizamos, e não simplesmente ignorá-las já que tal exclusão (proposital ou não) nos leva inevitavelmente ao aceite indiscriminado de sua irrelevância e a possibilidade clara do erro. Porém, se não podemos dar conta de todas as incertezas envolvidas, necessitamos ao menos de certos "controles informacionais" capazes de explicitar as relações entre variáveis independentes (processos), variáveis dependentes (respostas) e 
variáveis aleatórias ou estocásticas (eventos) envolvidas no universo de escolhas possíveis; no processo gerador das escolhas, e nas próprias escolhas em si.

O segundo elemento de proposição incide sobre as possibilidades do uso de controles e tratamento das informações em estudos de caráter geoarqueológico voltados à ambientes costeiros. Do ponto de vista arqueológico, a paisagem costeira é muitas vezes vista sob o ângulo da homogeneidade e estabilidade. Assim, no estudo da ocupação humana as áreas costeiras parecem fornecer condições climáticas mais estáveis que áreas interioranas (Fladmark 1979), apresentando ambientes mais uniformes ao longo de sua extensão, e condicionados por limites espaciais bem definidos (a presença do mar e, em algumas áreas, alinhamentos serranos). Esta caracterização aparentemente contrasta com os estudos geocosteiros, onde os ambientes costeiros são reconhecidamente complexos e dinâmicos, e cujos limites podem ter variado significativamente ao longo de sua evolução paisagística e climática.

No dizer de Ab'Sáber,

(...) na sua aparente simplicidade paisagística e na sua dinâmica habitual, exigem considerações similares, ou até mais complexas às dos espaços interiores, já que eles envolvem sérias questões relacionadas com as variações do nível do mar, paleoclimas e história vegetacional. Ou seja, o litoral, tal como outras áreas dotadas de paisagem ecológicas, pode ser considerado sempre como um herança de processos anteriores, remodelados pela dinâmica costeira hoje prevalecente. (...) Nesse contexto de metodologia e visualização pede-se afiançar que os litorais constituem-se em zonas de contato tríplices: terra, mar e dinâmica climática. (AB'SÁBER, 2006:80)

Deste modo, sob uma perspectiva de interrelação entre Arqueologia e estudos geocosteiros, a pesquisa aqui delineada irá se concentrar no estudo do Registro Arqueológico Regional de áreas costeiras, a partir do ângulo da heterogeneidade de dinâmica dos seus ambientes. Por sua vez, ao considerar a estrutura dos ambientes costeiros como uma herança de processos complexos morfodinâmicos, eustáticos, tectônicos, morfogenéticos, etc., verificase a incidência de problemáticas relativas à capacidade desses processos de produzir incertezas e viés interpretativo.

Das resoluções teóricas e analíticas a serem investigadas neste tipo de pesquisa, estão os seguintes pontos:

1) Necessidade de compreensão da variabilidade dos processos naturais de transformação atuantes em ambientes costeiros e sua influência sobre os processos de formação do registro arqueológico regional; 
2) A busca pelo entendimento das possíveis relações informacionais existentes na determinação e recuperação de "contextos arqueológicos" e qual o papel dos "contextos não-arqueológicos", no processo de seleção das informações utilizadas;

3) Como estabelecer "controles geoarqueológicos" visando à recuperação do Registro Arqueológico Regional em áreas costeiras, considerando a inserção da incerteza no processo de geração e modelagem de evidências e inferências.

O primeiro ponto insere-se nas pesquisas geoarqueológicas vinculada à compreensão dos processos de formação natural de sítios arqueológicos, tema este, vinculado a chamada Teoria de Formação ou Transformação (Schiffer, 1987, entre outros).

O segundo ponto refere-se à investigação dos processos de recuperação (Teoria de Recuperação) verificado nas relações informacionais entre sitio e meio (componentes naturais e analíticos). Este ponto cria um aparente contra-senso: a possibilidade de uma informação considerada não relevante (no sentido daquilo sem significado arqueológico e que, portanto, não foi selecionada como elemento de evidência e inferência arqueológica) de "carregar" informação "latente" relevante para a própria evidência/inferência em questão.

Este raciocínio gerou uma proposta conceitual que será chamada aqui de "Problema da Não-Informação", termo que também por si só poderia ser visto como outro contra-senso, já que em sentido amplo, não existiria algo que possa não ser informativo. Talvez uma das respostas seja que, quando ainda não estamos cientes desse algo, ele não é informativo, mas à medida que tomamos ciência dele, de uma de suas frações, o mesmo torna-se informativo ou "parcialmente" informativo. Daí decorre o pressuposto de que a informação é sempre situacional e circunstancial (BUCKLAND, 1991), e que irá depender das perguntas que serão feitas e dos contextos considerados.

Entretanto, na perspectiva aqui tratada, a Não-Informação deve ser vista (e como será posteriormente definida com maior clareza) sob o ângulo da abordagem dialética, de modo que não há um contra-senso, mas sim relações de contraste (contradição) e movimento que Ihe são inerentes. Neste ponto de vista, não informação é vista dentro de um processo situacional tese-antítese e, portanto, essencial à síntese e a seqüência do próprio movimento. Neste enquadramento, a não informação pode gerar uma base teórica e metodológica apropriada aos estudos geoarqueológicos, de modo a prover uma estrutura conceitual capaz de interagir com outros campos teóricos da arqueologia.

O terceiro ponto refere-se à elaboração de um método para o tratamento das fontes de informação e incerteza nos estudos geoarqueológicos de áreas costeiras. Neste caso é proposto o uso de Controles Geoarqueológicos como ferramenta de análise preditiva e retroditiva, permitindo a investigação de áreas complexas e onde não se dispõe de um 
banco de informações com significado estatístico ao qual se possam inferir as diferentes probabilidades para as diversas evidências.

\subsection{OS OBJETIVOS}

Podem ser enumerados os seguintes objetivos gerais e específicos da presente tese, que irão nortear o desenvolvimento dos capítulos, estabelecendo o enquadramento dos temas e problemáticas e, a organização dos produtos e resultados. São eles:

1. Fazer uma aproximação analógica entre a arqueologia e a ciência da Informação, verificando os problemas e soluções encontrados em ambas as ciências para as questões de informação, contexto e incerteza, permitindo elaborar e definir conceitos úteis para as teorias arqueológicas, bem como, na proposição de métodos de abordagem capazes de lidar com aspectos de complexidade no estudo da relação entre fenômenos culturais e naturais;

2. Propor um modelo de controle e tratamento de informações e incertezas no registro arqueológico regional, tendo por base a interação das teorias de formação e recuperação com a aplicação no campo da geoarqueologia e, notadamente, na geoarqueologia costeira no Brasil;

3. Definir e aplicar o conceito de "controles geoarqueológicos" em um estudo comparativo entre as áreas costeiras de Guaratuba-PR e Caraguatatuba-SP, permitindo testar hipóteses sobre a ocupação antiga nessas áreas.

4. Investigar o potencial de métodos derivados da Ciência da Informação na geração de modelos sobre ocorrência, preservação e detecção de sítios costeiros antigos, tendo por base modelos geomórficos, sedimentares e morfoestratigraficos produzidos para a costa sul-sudeste. 


\section{PRESSUPOSTOS PARA A ANÁLISE E TRATAMENTO DAS FONTES DE INFORMAÇÃO E INCERTEZA NO RACIOCÍNIO E PRÁTICAS ARQUEOLÓGICAS}

Compreender alguns dos principais mecanismos teóricos e metodológicos relacionados à produção de conhecimento científico torna-se o primeiro passo para a verificação do papel dos processos informacionais incidentes sobre esta forma peculiar de raciocínio. Por outro lado, permite delinear um campo preliminar, com limites ainda difusos, mas capaz de atender aos propósitos preliminares deste trabalho indicando ainda, alguns dos suportes conceituais que serão utilizados na seqüência do texto. Naturalmente um enfoque sobre "conhecimento" inevitavelmente recai nas possíveis fontes de certezas e incertezas que decorrem da busca pela apreensão dos fenômenos associados à chamada "realidade factual". Para a arqueologia esta busca é ainda mais difícil, pois muitos dos fenômenos a serem compreendidos não têm correspondência em fatos observados. Nossa "realidade factual" está nos artefatos, que nada mais são que "vestígios" arqueológicos, onde "quer se queira ou não, são apenas amostras de universos nunca completamente reconstituíveis "(GALLAY, 1986).

O aspecto fragmentado dessa realidade, apesar de impor limites à produção de evidências e inferências, não está fechado em si mesmo, visto que qualquer processo informacional visa à geração e à transmissão de conhecimentos. Para isso torna-se necessário avançar níveis cada vez mais abstratos e menos descritivos, onde novas correlações serão feitas. Esta espécie de aprimoramento ou escalada tem por base pressupostos genéticos e acumulativos, ou seja, só a partir de conhecimentos pré-existentes será possível reconhecer as informações pertinentes, as informações ausentes, ou ainda, aquelas informações novas. Considera-se que é nesta relação entre aspectos redundantes e o desconhecido (ou seja, a incerteza) que acham-se focados os métodos científicos capazes de produzir conhecimento nas diferentes ciências.

Mas qual será o método mais adequado ao tratamento das relações informacionais em arqueologia afim de produzir conhecimentos?. Neste capítulo pretende-se prescutar as diferentes possibilidades de métodos, indicando aquele considerado válido para as proposições e objetivos da presente tese.

\subsection{INCERTEZA E REDUNDÂNCIA EM MÉtOdOS CIENTÍFICOS: BASES PARA O ENTENDIMENTO DOS PROCESSOS INFORMACIONAIS LIGADOS À PRODUÇÃO DE CONHECIMENTO}


Se o papel do conhecimento consiste "em explicar o visível complexo pelo invisível simples" (MORIN, 2000 p.45, citando Jean Perrin), boa parte da aquisição do saber científico se dá por meio de processos inferenciais e interpretativos que buscam o desconhecido (explicans), ou seja, o fenômeno não observado. Porém, de forma geral, as abordagens dedutivas e indutivas, através de suas relações de conceituação, seleção e organização lógica tendem inevitavelmente a suprimir o caráter de ambigüidade, incompletude e incerteza relacionada aos fatos e idéias enquanto representantes daqueles fenômenos que são por essência, imprecisos e complexos.

Ao analisarmos questões sobre as formas de raciocínio científico, bem como a da aplicação das teorias científicas verificam-se ainda problemas como a da circularidade entre teoria e fato, já que conforme SOARES (2000, p.73): "Tem sido admitido que a melhor construção científica, modelo ou teoria, é aquela que explica melhor as observações e faz as melhores predições. Mas como se 'é a teoria que decide o que observamos'?" (citando Einsten, apud Heisenberg, $1971^{3}$ )

Por outro lado, se é esta inter-relação constante entre teoria e fato que caracteriza o desenvolvimento da ciência, como se dá a inserção do "não observável", do preditivo, no método científico? Afinal, é a capacidade de "transcendência" dos fatos, inferindo o que pode haver por trás e além deles, que permite à ciência ampliar e reformular conhecimentos. Assim, ao inquirir como são as coisas, para que servem e quais as razões para aceitá-las como fato, buscam-se não apenas a explicação daquilo que é conhecido, mas também formular conjecturas e hipóteses sobre aquilo que se procura compreender, ou seja, o fato desconhecido.

Este aspecto eminentemente epistemológico (ou seja, como são produzidas as explicações científicas, suas implicações e alcances frente ao problema do conhecimento) é importante, já que incide por um lado, na percepção e entendimento prévio de cada pesquisador sobre as relações sujeito/objeto, sujeito/teoria e teoria/objeto que irá guiar muitos dos seus procedimentos na resolução dos problemas. Por outro, em sua adequação a limites pretensamente bem demarcados do raciocínio e linguagem científica, cujas afirmações e confirmações são construídas a partir de regras vinculadas, entre outros, à lógica e à sintaxe (SOARES, 2000). Neste sentido, segundo OLIVA (2003) quando buscamos a elucidação da racionalidade científica, muito contribuí dissecá-la em termos de seus componentes sintáticos, semânticos e pragmáticos:

\footnotetext{
${ }^{3}$ Heisenberg, W. Physics and Beyond. New York: Harper \& How, 1971. 228p.
} 
O discurso científico bem construído, sobretudo quando tem pretensões cognitivas, deve ser: 1) formalmente impecável (requisito sintático); 2) referir-se de maneira unívoca a estados da realidade (requisito semântico). Só assim pode se habilitar a 3) convencer (requisito pragmático) a comunidade de pesquisadores do valor explicativo das teses defendidas. (OLIVA, op cit. p.13)

Conforme LAKATOS e MARCONI, (2004, p.20) o que se entende por conhecimento científico apresenta em sua essência, características inerentes de contingência (sua veracidade ou falsidade pode ser conhecida por meio da experimentação, do acaso, da descoberta e não apenas pela razão); sistematicidade (ordenação de um saber, de forma lógica, formando um sistema de idéias); verificabilidade (as afirmações precisão ser confirmadas) e; de faliabilidade (não é definitivo, ou seja, é aproximadamente exato).

A ciência, tida como conhecimento estruturado, teria por objeto uma hipotética realidade universal ou factual, visto que se fundamenta essencialmente nas evidências empíricas para construir modelos que reflitam ou expliquem o funcionamento dessa realidade, ou de suas frações particulares. No sentido desta definição preliminar, o conhecimento científico objetivo está vinculado ao "real" ou ainda, ao factual, expressado pelos fenômenos que são adquiridos através de qualquer "forma de existência que se manifesta de algum modo" (TRUJILLO FERRARI, 1974, p.14).

Entretanto, conforme Popper (1992) os modelos baseados na experiência sensível não podem ser logicamente confirmados, mas apenas refutados quando da ocorrência de casos que contradigam o modelo. Considerando que boa parte das conjecturas científicas se dá por processos indutivos (pela observação de casos particulares), não haveria meios de confirmar sua verdade, mas apenas uma aproximação desta, obtida através de argüições lógicas e constantes contrastações empíricas.

Sobressai nas questões acima, o papel da teoria enquanto princípio de seleção e sistematização de fatos e conceitos,

(...) a teoria refere-se a relações entre fatos ou, em outras palavras, à ordenação significativa desses fatos, consistindo em conceitos, classificações, correlações, generalizações, princípios, leis, regras, teoremas, axiomas, etc. (...) Não existe teoria sem ser baseada em fatos; por sua vez, a compilação de fatos ao acaso, sem um princípio de classificação (teoria), não produziria a ciência - ter-se-ia um acúmulo de fatos não sistematizados, não relacionados, mas amorfos e dispersos, impossíveis de serem interligados e explicados. (...) A teoria serve como sistema de conceitualização e de classificação de fatos - um fato não é somente uma observação prática ao acaso, mas também uma afirmativa empiricamente verificada sobre o fenômeno em pauta: desta forma, engloba tanto as observações científicas quanto um quadro de referência teórico 
conhecido, no qual essas observações se enquadram. No universo, a variedade de fenômenos passíveis de estudo é infinita; entretanto, a ciência seleciona aqueles que deseja estudar e, além disso, os abstrai da realidade, escolhendo alguns aspectos do fenômeno (massa, velocidade, graus de socialização, etc.), não estudando, portanto, todo o fenômeno. Constitui, assim, um ato de abstração separar qualquer fenômeno de tudo aquilo com que está relacionado. (LAKATOS e MARCONI, 2004:99-101) [grifo nosso]

Em uma visão oposta de ciência, alicerçada sobre os problemas da significação, seleção e abstração, pode-se considerar similarmente a KANT (1999), que o próprio mundo dos fenômenos (palavra que etimologicamente significa "o que aparece"), só existe na medida em que 'aparece' para nós e, portanto, de certa forma participamos de sua construção. Ainda nesse sentido, as atividades de geração de evidências empíricas podem refletir uma total dependência em relação às teorias que nelas são empregadas, o que implica em dúvidas sobre sua capacidade de confirmação, refutação, etc, ou ainda, pode resultar simplesmente em uma demarcação paradigmática, tendo por base as realizações ditadas por tradições científicas (KUHN, 1970)

Deve-se considerar finalmente, que a forma como são percebidos, registrados e explicados os fatos decorre não somente da mente racional, mas também da mente emocional, já que segundo SOARES (2000:78): "É impossível retirar a subjetividade, a base teórica e a experiência prévia na percepção do objeto ou fenômeno, como proposta idealizada pela investigação científica". Para Souza Santos (19894, apud PACHECO, 1992:40) um dos debates mais significativos da ciência moderna está, desde Bacon e Descartes, em identificar o papel do sujeito e do objeto, da teoria e dos fatos, ou ainda, dos conceitos e da observação na criação do conhecimento ${ }^{5}$. No entanto, para o autor, não há como negar a diferença entre objetos de conhecimento e os seus referentes na realidade material, não significando com isso, que não haja relações entre eles.

Outra questão de caráter mais metodológico derivado da ligação entre teoria e fato é a concepção da capacidade da primeira, enquanto apoiada pelo segundo, de permitir predições sobre os fenômenos, muitos dos quais, inobserváveis. Este pressuposto permitirá, em um sentido geral, a elaboração de modelos explicativos sobre os acontecimentos e compreendê-los em sua sucessão, tais como aqueles propostos por Hempel (nomológico-dedutivo) ou W. Salmon (modelo da relevância estatística). Ainda, conforme DUTRA (op cit. p. 23), a crítica aos próprios pressupostos explicativos, como

\footnotetext{
${ }^{4}$ Souza Santos, B. Introdução a uma ciência pós-moderna. Porto: Afrontamento, 1989.

${ }^{5}$ Neste debate histórico, polarizam-se as correntes objetivistas, naturalistas e empiristas (que privilegiam os objetos, fatos e observação) em contraposição às correntes racionalistas, idealistas e subjetivistas (que privilegiam o sujeito, a teoria e os conceitos).
} 
relacionados entre outros, à capacidade de apontar uma causa específica para determinado fato (este tomado como o efeito) resulta em propostas alternativas, tais como a do modelo pragmático de Bas van Fraassen ${ }^{6}$ que considera a explicação como uma relação de três termos: teoria, fato e contexto.

Por sua vez, a percepção de lacunas e incertezas no conhecimento (sejam relacionadas às teorias, fatos ou contextos), expressadas através das problemáticas encontradas na pesquisa, podem fazer com que o pesquisador formule algumas conjecturas ou hipóteses, mesmo que não tenha uma base segura de evidências. Esta espécie de "explicação previa" conduz à dedução de determinadas conseqüências, que poderão ser confirmadas pela a busca de novos dados. Para evitar a circularidade (procurar nos dados apenas a confirmação da hipótese), a utilização do chamado de método hipotético-dedutivo (Popper) permite o falseamento da hipótese, que nada mais é que a extração de implicações empíricas da hipótese, permitindo a busca de evidências capazes de derrubá-la. Quando não se consegue falsear a hipótese, tem-se a sua corroboração, que jamais deve ultrapassar o nível do provisório já que a qualquer momento poderá surgir um fato que a invalide.

Na mesma linha de percepção de lacunas e incertezas está o método abdutivo, mas que na realidade, conforme PEIRCE (1975), vem a se constituir no próprio processo de formulação de hipóteses em ciência. Entretanto, pode-se ressaltar que diferentemente do método hipotético-dedutivo, o raciocínio abdutivo (ou ainda, de inferência hipotética, retrodução), coloca a possibilidade de uma maior liberdade na forma de condução do processo inferencial. De modo simplificado, conforme CHIBENI (1996)

(...) o esquema geral dos argumentos abdutivos, tais quais aparecem nas discussões contemporâneas, consiste no enunciado de uma evidência (um fato ou conjunto de fatos), de hipóteses alternativas para explicar tal evidência, e de uma apreciação do valor dessas explicações. A conclusão é a de que a melhor explicação provavelmente é verdadeira se, além de comparativamente superior às demais, for boa em algum sentido absoluto (CHIBENI, 1996:45)

O raciocínio abdutivo, também considerado como raciocínio das descobertas científicas, pode-se aproximar do "método" dialético, na medida em que este, diferentemente da explicação causal, consiste em um modo esquemático de explicação dos fenômenos a partir de oposições, tensões e choques entre situações diversas ou contraditórias. Ou seja, o

\footnotetext{
${ }^{6}$ VAN FRAASSEN, B.C. The Scientific Image. Oxford, Clarendon Press, 1980.
} 
método dialético procuraria a contextualização dos fenômenos, na busca por elementos conflitantes entre dois ou mais fatos para explicar uma nova situação decorrente desse conflito (Demo, 2000).

Neste ponto, deve-se retomar a análise do poder explicativo das teorias, dos modelos ou métodos que podem ser utilizados nesta tarefa. Assim, à semelhança das argumentações colocadas por DUTRA (2003), serão a princípio explicitados os modelos nomológicodedutivo, de Hempel, e o da relevância estatística, de Salmon, considerados os mais conhecidos, em contraponto ao modelo pragmático de VAN FRAASSEN $(1980,2007)$, considerado aquele que parece atender melhor a algumas das problemáticas apresentadas nesta tese, e portanto mais apto a lidar com os fenômenos arqueológicos.

No modelo nomológico-dedutivo ou D-N, um explicação é dada por "um argumento dedutivo cuja conclusão é uma descrição do fenômeno a ser explicado (o explanandum) e cujas premissas (ou conjunto de premissas) são de dois tipos: (a) enunciados que fazem afirmações sobre fatos particulares relacionados com o fenômeno a ser explicado, e (b) aquelas que descrevem uniformidades, expressas por meio de leis gerais" (DUTRA, 2003; LAKATOS e MARCONI, 2004) (o explanans, que podem ser não apenas de base dedutiva, mas também estatístico-indutiva). Assim, se o que foi narrado nas premissas é verdadeiro então o fato a ser explicado ocorrerá necessariamente, podendo-se prever a ocorrência de um fenômeno tendo-se apenas as premissas. Entretanto, neste modelo, exige-se a veracidade dos fatos e enunciados gerais (leis) o que implica em requisitos de verificabilidade, que para as ciências interpretativas e históricas, como a geologia (FRODEMAN, 1995) e a arqueologia, pode se constituir um problema, já que nestas "a relação entre os fatos e conclusões são tanto concorrentes como conflitantes, impedindo que se alcance uma conclusão dedutiva irrefutável" (SOARES, 2000, p.73)

No modelo de relevância estatística ou S-R, a explicação seria dada pelo "conjunto de sentenças que fornece uma base para inferir o fato a ser explicado ou, melhor dizendo, com que probabilidade podemos esperar que tal fato ocorra" (DUTRA, 2003:122). Embora este modelo também considere que as leis são necessárias à explicação, a diferença recai na percepção que um conjunto de sentenças não se refere a premissas colocadas em apoio a uma conclusão (argumento de verdade) e sim a regularidades probabilísticas entre classes e sentenças em um dado conjunto. A aceitação de uma explicação tipo S-R considera, entre outros, que o conjunto de fatores colocados como explicação deva ser estatisticamente relevante. (ibidem, p.123). Porém, a impossibilidade de observar e medir o comportamento de inúmeras variáveis em diferentes processos e sistemas (como no geológico e no arqueológico) aponta para as problemáticas relacionadas às insuficiências (fatos insuficientes) e tendências (representatividade dos fatos) na determinação das parcelas (amostras) e dos universos (populações) considerados. 
Por fim, o modelo pragmático de van Fraassen contrasta com os acima, no sentido que naqueles, a explicação estaria na relação de dois termos, como leis gerais e fatos (Hempel), seja sentenças relevantes e fatos (Salmon). Para van Fraassen existiria um terceiro termo, o contexto, que pode interferir no poder explicativo de uma lei, fato ou conjunto de fatores relevantes. Deste modo, uma teoria científica capaz de dar boas explicações em determinados contextos pode não permiti-las em outros. Essa idéia implica em relativisar (contextualizar) o problema da determinação das causas de um evento. Em seu modelo, a explicação também é uma resposta a uma questão "por que", mas que admite interpretações com base em fatores como (1) "classe-de-contraste", (2) "tópico" e (3) "relação de relevância". A primeira corresponde ao contraste entre um elemento de uma classe de possibilidades e os outros; o segundo é o assunto em questão, representado por um dos membros da classe de contraste; o terceiro refere-se "aquilo a respeito de quê se pede uma razão, aquilo que conta como um fator explicativo" (DUTRA. 2003:128).

Como exemplo colocado pelo autor citado (ibidem, p.127), tem-se que na questão "Por que Adão comeu a maçã?, a existência de diferentes alternativas de ênfase (Quadro 1) cada qual com diferentes tipos de respostas.

Quadro 1: Alternativas de ênfase à questão "Por que Adão comeu a maçã?" em uma análise vinculada ao modelo pragmático de explicação (adaptado de Dutra, 2003:127):

\begin{tabular}{|c|c|c|c|}
\hline $\begin{array}{c}\text { ENFASE } \\
\text { (INTERPRETAÇÃO) }\end{array}$ & AO AUTOR DA AÇÃO & $\begin{array}{l}\text { AO OBJETO QUE } \\
\text { SOFREU A AÇÃO }\end{array}$ & $\begin{array}{c}\text { A AÇÃO ESPECÍFICA } \\
\text { REALIZADA }\end{array}$ \\
\hline Questão (n) & $\begin{array}{l}\text { (1) Por que foi Adão que } \\
\text { comeu a maçã? }\end{array}$ & $\begin{array}{l}\text { (2) Por que foi a maçã } \\
\text { que Adão comeu? }\end{array}$ & $\begin{array}{l}\text { (3) Por que Adão comeu a } \\
\text { maça? }\end{array}$ \\
\hline Questão (n') & $\begin{array}{l}\text { (1') Por que foi Adão e } \\
\text { não Eva? }\end{array}$ & $\begin{array}{l}\text { (2') Por que foi a maçã e } \\
\text { não um morango? }\end{array}$ & $\begin{array}{l}\text { (3') Por que Adão comeu } \\
\text { a maçã, e não a deu a } \\
\text { Eva? }\end{array}$ \\
\hline $\begin{array}{l}\text { Classe de contraste } \\
(X)\end{array}$ & Adão, Eva, Caim, Abel, & Maçã, morango, banana, & $\begin{array}{l}\text { Comer, dar a alguém, } \\
\text { jogar fora }\end{array}$ \\
\hline Tópico & Adão & Maçã & Comer \\
\hline $\begin{array}{l}\text { Relação } \\
\text { relevância }\end{array}$ & $\begin{array}{l}\text { Proximidade ou } \\
\text { distância com a maçã }\end{array}$ & $\begin{array}{l}\text { A Presença ou ausência } \\
\text { de outras frutas }\end{array}$ & $\begin{array}{l}\text { Adão estava ou não com } \\
\text { fome? }\end{array}$ \\
\hline $\begin{array}{l}\text { Possíveis respostas } \\
\text { para questão por que }\end{array}$ & $\begin{array}{l}\text { Foi Adão que comeu a } \\
\text { maçã, e não outra } \\
\text { pessoa, porque apenas } \\
\text { estava próximo dela; }\end{array}$ & $\begin{array}{l}\text { Foi a maçã que Adão } \\
\text { comeu porque não havia } \\
\text { outras frutas no jardim } \\
\text { do Éden; }\end{array}$ & $\begin{array}{l}\text { Adão comeu a maçã, ao } \\
\text { invés de dá-la a Eva, } \\
\text { porque estava com fome; }\end{array}$ \\
\hline
\end{tabular}

Segundo FRASSEN (1980, p.129), para a identificação de quais as classes-de-contraste mais adequadas e, conseqüentemente, qual das possíveis respostas à questão acima daria uma explicação para o fato em questão, somente pode ser determinada pelos contextos. Portanto sem um contexto qualquer não haveria como determinar a classe-de-contraste e 
também, que fatores podem ser considerados mais relevantes ${ }^{7}$. Outro aspecto importante, dentro desta "teoria pragmática", é que ela delega aos contextos aquilo que pode nos dizer em que circunstâncias um de dois eventos inter-relacionados poderia ser a causa ou fator explicativo para o outro. (DUTRA, op cit: 131).

Deduz-se da teoria pragmática de Frassenn que se os contextos são condicionamentos importantes na explicação de fenômenos, fatos ou eventos, e estes por sua vez, também poderiam ser determinados por relações de contraste, tópico e relevância.

Mas, quando não conhecemos completamente os contextos e suas relações? Ou ainda, quais os tipos de relações contextuais envolvidos em uma determinada explanação científica?

Na primeira pergunta, podemos verificar no Quadro 2, que as possíveis respostas para a questão "por que" se enquadram perfeitamente no conceito de inferências abdutivas, ou seja, referem-se basicamente a hipóteses geradas a partir dos fatores considerados. Assim, também é possível delimitar os contextos a partir da formulação de hipóteses contrastantes sobre os fenômenos, fatos ou eventos.

Para a segunda pergunta, torna-se útil considerar conforme Eugene Meehan (1968, apud DUNNELL, 1971:19), as duas classes de explanação ou metas em ciência:

“(1) predição - uma declaração (afirmação) estatística da probabilidade de um determinado evento como o resultado de uma seqüência conhecida de eventos anteriores; e (2) controle - uma declaração da relação de um determinado evento a outros eventos e conjuntos de eventos os quais permitiria um (deles) modificar o resultado de uma seqüência para um resultado específico, alterando um ou mais dos fatores relacionados".

Se associarmos predição e controle à perspectiva de Frassenn torna-se então necessário determinar, por um lado, qual o contexto existente nas declarações de relação e de seqüência entre eventos (ou conjuntos de eventos) que tenham como propósito predizê-los e/ou controlá-los. Da mesma forma, o raciocínio abdutivo pode ser solicitado, onde hipóteses alternativas poderiam ser formuladas visando explicar a relação entre evidências e inferências e, de uma apreciação do valor dessas explicações (necessária para selecionar a melhor hipótese).

\footnotetext{
${ }^{7}$ Como um exemplo, temos o problema da causa morte de um motociclista em um acidente, onde para o guarda de transito foi à alta velocidade, para o borracheiro foram os pneus desgastados, para o técnico de segurança foi à falta de capacete e para o médico, foi o traumatismo craniano.
} 
Decorre daí a proposição nesta tese de que estes "contextos relacionais" sejam compreendidos, analisados, previstos e controlados, a partir dos processos informacionais subjacentes aos métodos de aquisição e transmissão de informações e conhecimentos, visto que um caráter da informação é que ela é sempre situacional (BUCKLAND, 1991). Neste sentido as relações de contraste ou classes de contraste apresentam forte correspondência com o aspecto seletivo quantitativo da informação (enquanto fonte de variabilidade seletiva). Por sua vez, a relevância relaciona-se ao seu aspecto seletivo qualitativo (enquanto informação já selecionada e direcionada a outros níveis de análise e comunicação).

Neste aspecto podemos buscar relações analógicas com termos da Ciência da Informação (Cl) que apresentam conceitos profundamente atrelados aos aspectos seletivos, contextuais, interpretativos e comunicativos.

Capurro e Hjorland $\left(2003^{8}\right.$ apud AZEVEDO, 2004) consideram que embora os diferentes conceitos de informação existentes na $\mathrm{Cl}$ reflitam tensões entre visões subjetivistas e objetivistas, sugerem que o seu entendimento seja compreendido a partir dos processos interpretativos ligados aos mecanismos de processamento e liberação da informação.

Ainda conforme E. Morin, a informação,

(...) não é nem uma coisa nem um conceito puramente formalizador. A informação é um conceito físico relacional; é neste sentido que ela tem dimensão zero. O erro ontológico é de localizar a informação no signo que a inscreve ou no sinal que a veicula. A grande virtude da teoria shannoniana é de ter definido a informação como uma relação factual em situação. Ela passa a existir na relação emissor/receptor no momento do ato de recepção (...) A informação é, portanto, sempre ativamente relacionada e relacionante." (MORIN, 2005:413)

Assim, por exemplo, as palavras dados e informação embora sejam intercambiáveis em muitos contextos, não são sinônimos. Para campos mais práticos da ciência, como na tecnologia dos Sistemas de Informação Geo-referenciadas (SIGs), a sua principal diferença é que a primeira corresponde a um conjunto de valores numéricos ou não, que se pretende à descrição qualitativa e/ou quantitativa de fatos do mundo real, e teriam como característica principal a sua reprodutividade, na medida que fossem satisfeitas as mesmas condições

\footnotetext{
${ }^{8}$ CAPURRO, Rafael.; HJORLAND, Birger. The concept of information. In: WILLIANS M. E. (Ed.). Annual review of information science and technology, Medford, NJ: Information Today, 2003. v. 37.
} 
de coleta (SILVA,1999). Enquanto a informação comporia um conjunto de dados que possui um determinado significado, ou seja, foi agregado ao dado um componente adicional, a interpretação. "Quando se agrega valores intelectuais, subjetivos, aos dados estes se transformam em informações. (...) Quando as informações são utilizadas e praticadas pelos seres humanos, estas se constituem no chamado conhecimento, (...)"(SILVA, op cit. p.21).

Por sua vez, o campo disciplinar encarregado de compreender e aplicar o conceito de informação refere-se à Ciência da Informação $(\mathrm{Cl})$, cujas origens decorrem do próprio crescimento exponencial da informação partir da década de 1930 (PINHEIRO e LOUREIRO, 1995), mas que a partir da segunda metade da década seguinte passou por importantes mudanças no referencial teórico-metodológico. Conforme AZEVEDO (op cit:127),

\begin{abstract}
Essa mudança foi desencadeada pela "teoria da informação" (Shannon e Weaver) e a cibernética (Wiener), na medida que, por sua vez, estimularam a chamada cibernética de segunda ordem (Foerster, Maturana e Luhmann) que, juntamente com a semiótica (Pierce), influenciaram a discussão epistemológica da Cl."
\end{abstract}

Das primeiras definições mais amplas de $\mathrm{Cl}$ está aquela que investiga

\begin{abstract}
"as propriedades e o comportamento da informação, as forças que governam o fluxo da informação e os meios de processamento para acesso e uso otimizados. Ela diz respeito àquele corpo de conhecimento ligado à origem, coleta, organização, armazenagem, recuperação, interpretação, transmissão, transformação e utilização da informação“" (Borko, 1968 apud PINHEIRO e LOUREIRO, 1995)
\end{abstract}

Para a melhor compreensão das proposições ligadas a esta primeira corrente de pensamento faz-se necessário o entendimento de alguns de seus princípios básicos derivados da teoria informacional shannoniana, que podem ser sintetizados, nas problemáticas ligadas aos conceitos de informação e redundância.

Conforme FIDALGO (2004), informação e redundância são dois termos fundamentais da Teoria Matemática da Comunicação ${ }^{9}$, e são definidos a partir do conceito filosófico amplo de certeza (ou ainda, incerteza). É preciso considerar que tal teoria fundamenta-se

\footnotetext{
${ }^{9}$ Aqui cabe uma ressalva, segundo COELHO NETTO (2003:121). "há uma tendência no sentido de encarar a Teoria da Informação como um estudo da estruturação da mensagem formalmente considerada e a Teoria da Comunicação como o estudo do relacionamento mensagem-fonte receptor; [Ou ainda] (...) a Teoria da Informação trata do sistema (conjunto de elementos e suas normas de combinação) do qual a Comunicação é o processo (seqüência de atos espaçotemporalmente localizados)" Para o caso da presente tese, no entanto, os dois termos serão utilizados segundo um mesmo sentido, que englobaria o alcance de ambas as definições acima.
} 
essencialmente nas relações de quantidade ou medida de informação veiculada por um canal, não havendo neste caso correspondência entre informação e significado. Em um sentido similar, não interessaria à análise informacional o que está sendo transmitido em uma mensagem, mas sim quanto, seja em termos da intensidade das mudanças por ela promovidas, ou ainda, de quantas dúvidas ela elimina. (COELHO NETTO, 2003:120).

Em FIDALGO (op cit: 17), citando Shannon \& Weaver ${ }^{10}$, o termo informação "não respeita tanto ao que de facto se diz, mas como ao que poderia ser dito. Isto é, informação é uma medida da liberdade de escolha quando se seleciona uma mensagem", ou ainda conforme Umberto Eco, "representa a liberdade de escolha disponível para a possível selecção de um evento, constituindo, pois, uma propriedade estatística da fonte" (ECO, 1991) [grifo nosso].

Neste último sentido, a característica eminentemente probabilística da informação remete a percepção de que sua unidade básica (ou informação mínima) não está na mensagem ou percepção de um fato, mas sim na escolha entre pelo menos duas mensagens possíveis. Conforme o mesmo autor, a teoria informacional estabelece que "informação dada é inversamente proporcional a sua probabilidade, ou seja, que a informação é uma propriedade estatística de um signo ou de uma mensagem" (FIDALGO, op cit: 15). Esta intelecção pressupõe que quanto maior a probabilidade de um signo, menor sua informação, ligando informação à incerteza e redundância à certeza ("se houvesse apenas uma mensagem então não haveria qualquer informação na medida em que não haveria qualquer incerteza")

A relação acima, à primeira vista, se contrapõe ao modelo clássico de conhecimento, onde o processo de "adquirir certezas" é considerado um processo informativo. No entanto, neste mesmo modelo "cartesiano" conhecer é tornar o que é desconhecido em conhecido e, portanto, a incerteza é condição de novos conhecimentos. Mas cabe lembrar que não haveria possibilidades de associação prévia entre os dois modelos, visto que na abordagem tradicional a certeza é substantiva (conteúdo), ou seja, carregada de significados.

Quantificar informação também equivale a medir o número de escolhas possíveis dentro de um quadro probabilístico o que remete à noção de que em um conjunto de escolhas possíveis, poderão existir ainda aquelas com maior ou menor probabilidade de serem selecionadas. Estas relações podem ser traduzidas pela percepção de que a quantidade de informação também está vinculada ao grau de "novidade" de uma informação, ou seja, quanto mais um dado for diferente daqueles que o rodeiam (no espaço/tempo), maior

${ }^{10}$ SHANNON, C. \& WEAVER, W. The mathematical theory of communication. Urbana, Univ. of Illinois Press, 1949. 
quantidade de informação; e quanto mais um dado estiver distribuído aleatoriamente, mais baixa é sua informação.

Outro ponto é que em uma seqüência consecutiva de escolhas, o grau de liberdade poderá diminuir progressivamente, já que as escolhas seguintes estão limitadas e condicionadas às escolhas prévias. O grau de liberdade de escolha está relacionado ao conceito de entropia na Teoria Matemática da Comunicação, de tal forma que um maior grau de liberdade equivale a uma maior entropia do sistema (menos ordenado) e a uma maior informação contida (tendo por referência a fonte de informação).

A definição acima, portanto, difere das abordagens que consideram a informação como entropia negativa (neguentropia), ou seja, relacionada ao grau de ordem ou organização de um sistema. Nesta segunda visão, a entropia é entendida de forma análoga a uma medida de probabilidade termodinâmica, sendo que aonde existe um elevado grau de aleatoriedade (maior entropia $=$ maior desordem) dos elementos de um sistema, sua distribuição será igualmente provável e tenderá a uniformidade, representando baixa informação. Por sua vez, uma distribuição orientada, selecionada ou original de elementos aponta para uma organização "improvável" cujo grau de ordem ou excepcionalidade remete a uma maior informação no sistema.

Entretanto, como se verá adiante a contraposição entre os dois modelos ocorre apenas devido a uma mudança de referencial. Na primeira acepção, a referência é a fonte de informação, ou seja, refere-se uma propriedade estatística da fonte; na segunda, a referência é a informação selecionada, relevante, que faz sentido em um determinado processo comunicacional.

Voltando a percepção shanonianna, a entropia máxima remete à existência de uma total equi-probabilidade entre as possibilidades de escolhas, sendo um dos casos onde informação máxima e mínima se equivalem (considerando que apesar da elevada quantidade de informação na fonte, o receptor não tem parâmetros de seleção e transmissão). Por sua vez, uma entropia efetiva deriva da percepção daqueles condicionamentos ou limitações de seleção, seqüência de escolhas prévias, etc. sendo que esta é determinada pela relação entre a entropia máxima (máxima liberdade) e a entropia relativa da fonte (grau de liberdade restante, retirando-se as restrições de seleção da fonte). Por sua vez, a diferença existente entre entropia máxima e relativa equivale à chamada redundância de um sistema ou mensagem.

Este último termo designa a fração da estrutura da mensagem que não é determinada pela livre escolha do emissor, mas que ao mesmo tempo equivaleria em um sentido, a uma espécie de informação recorrente, e até certo ponto desnecessária, assemelhando-se a um ruído que não interfere no processo comunicacional. 
Como exemplo, FERNANDES e AZEVEDO (2006:5), ao considerarem a transmissão de textos em português, verificaram que existem diferentes freqüências nas letras utilizadas, mas também que sua seqüência não se apresenta completamente aleatória tendo, portanto, uma estrutura estatística "na fonte" (Figura 2). Esta característica estrutural pode ser considerada um exemplo dos condicionantes informacionais envolvidos em uma análise de redundância. Assim, calculando a probabilidade de ocorrência da letra "i" no português (0,056 - valor para 3.500 .000 letras), os autores chegaram a uma entropia relativa de $84,4 \%$ o que remete a uma redundância da ordem de 15\% (para apenas uma letra), valor este que poderia ser eximido do texto em questão sem qualquer prejuízo de sua mensagem (princípio da compactação em informática).

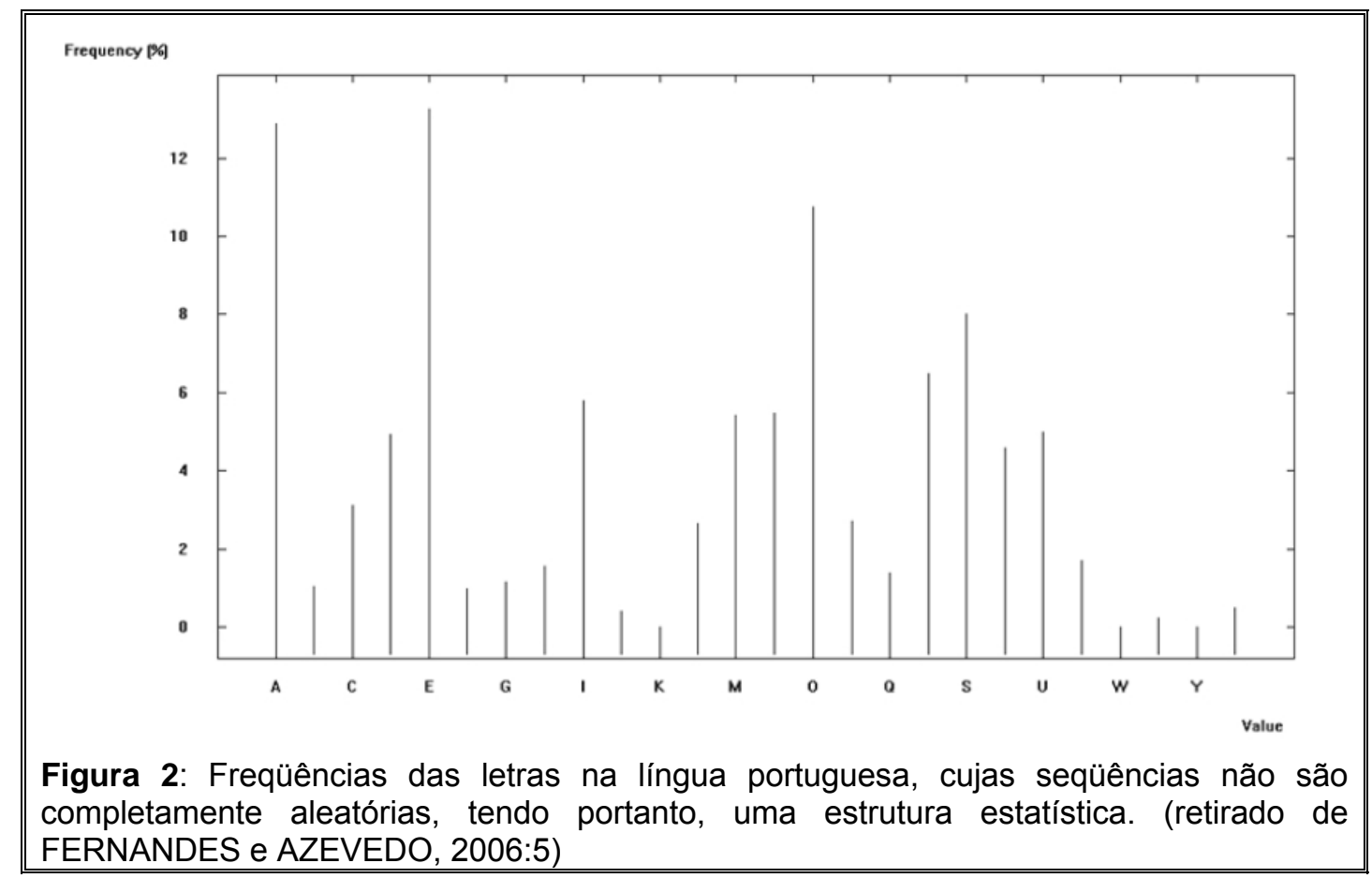

Entretanto, conforme FIDALGO (op cit. p. 23) torna-se imperativo distinguir entre os elementos imprescindíveis que são estruturantes da própria mensagem, e os elementos prescindíveis em um processo de comunicação entre emissor e receptor:

Seguindo o próprio modelo comunicacional de Shannon - fonte de informação, transmissor, sinal emitido, canal, sinal recebido, receptor, destinatário -, é condição fundamental de uma comunicação efectiva que a codificação da mensagem seja bem feita. O código constitui aqui um elemento essencial que deve ser partilhado por ambos os lados do processo comunicativo. Ora é justamente essa partilha, esse ponto comum, que constitui a redundância necessária subjacente à comunicação. Ou seja, apesar da redundância não representar qualquer informação, ela é fundamental para a exactidão da mensagem e mesmo para sua ocorrência (ibidem, p. 24) [grifo nosso] 
Outro aspecto refere-se à necessidade de definição do universo representado pelo conjunto das escolhas possíveis, que constitui a condição de seleção e, portanto a sua redundância implícita. Para Fidalgo só teria sentido falar de incerteza probabilística dentro de um quadro finito de possibilidades, quadro este escolhido por razões de conteúdo (ou estratégia) e que seriam, então, não probabilísticas. Deste modo, "a incerteza informativa e probabilística tem como condição a certeza substantiva enquanto quadro de incerteza" (ibidem, p. 17, grifo nosso) o que revelaria segundo ele, o sentido essencial de redundância. Em Santos et al. (2003, s/n) podemos verificar como a redundância é necessária para a identificação de padrões necessários a extração das informações:

\begin{abstract}
A redundância de uma informação é o inverso da entropia relativa. Sendo a entropia relativa a proporção de entropia presente em relação à máxima quantidade possível de entropia. A redundância é a proporção de o quanto uma situação é previsível, em outras palavras, o grau de certeza da informação. Através da redundância se consegue gerar o grau de previsibilidade de uma dada situação. Um dos processos de extração de informações é a classificação, que abrange um conjunto de técnicas, que podem ser matemáticas ou estatísticas, que visam reconhecer padrões e objetos homogêneos. As técnicas de classificar informações, consistem, basicamente, em separá-los colocando-os em grupos previamente definidos. Ao se agrupar as informações em características similares (classificação), se utiliza o critério baseado na redundância destas informações. Ao se agrupar as informações, se reduz a entropia. Em sistemas altamente entrópicos, cada informação é única, mas ao serem agrupados, por sua redundância inerente ao tipo de informação que se deseja obter, diminui-se a entropia e o número de informações, e consequentemente, reduz-se a incerteza.
\end{abstract}

Conforme MORIN (2005 p.366) a idéia de redundância aparece como "um excedente inútil sob o ângulo da economia, mas que no aspecto da fiabilidade da transmissão, representaria uma condição de prevenção contra os riscos de ambigüidade e de erro na recepção." Ainda segundo Fiske ${ }^{11}$, citado por FIDALGO (2004 p. 24), "Shannon e Weaver mostram como a redundância facilita a exactidão da descodificaçao e fornece um teste que permite identificar erros. Só me é possível identificar um erro ortográfico devido à redundância da linguagem. Numa língua não redundante, mudar uma letra significaria mudar a palavra",

Por outro lado, Morin faz críticas à informação Shannoniana pela sua incapacidade de gerar novas informações, apontando que ela é sempre pré-gerada e sempre degenerativa (só tende a decrescer da emissão à recepção) e obedece, portanto, ao princípio da entropia

\footnotetext{
${ }^{11}$ Introdução ao Estudo da Comunicação, Lisboa:Edições Asa, 1993, p.25.
} 
crescente, embora se possa retardar o "efeito inelutável do ruído" através de um bom uso da redundância. Considera ainda que haja um problema-chave "que não apenas a teoria, mas também a lógica do entendimento clássico impede de compreender: como é que a informação, para ser gerada, precisa necessariamente da não informação, ou seja, da redundância e do ruído?" (MORIN, 2005 p.380)

No entanto é possível que seja nesta contraposição e na dependência da informação (como incerteza) com as entropias negativas (enentropia = ordem) que possam haver ganhos informacionais. A enentropia, ao representar a negação da uma negação (a entropia), faz eclodir sua positividade, visto que "não anula aquilo que nega, ela transforma-o, forma-se e deforma-se nele" (MORIN, 2005 p. 361).

É neste sentido que pode existir uma aproximação da Teoria da Informação com a dialética hegeliana, da unidade dos contrários. Segundo Simondon (1964 apud GARCIA dos SANTOS, 2007),

"A informação é essa aptidão de relacionar que fornece uma resolução, uma integração; é a singularidade real através da qual uma energia potencial se atualiza, através da qual uma incompatibilidade é superada; a informação é a instituição de uma comunicação que contém uma quantidade energética e uma qualidade estrutural; "é aquilo através do qual a incompatibilidade do sistema não resolvido torna-se dimensão organizadora na resolução." (Simondon, 1964:15 ${ }^{12}$ )

De forma a resumir as diferentes visões sobre o papel da informação na produção de incertezas ou de conhecimento organizado serão são apresentados os seguintes referenciais utilizados nas diferentes definições do seu conceito, ou ainda, no posicionamento do que se entende por informação quanto relacionada a objetos, representações, fontes potenciais ou probabilísticas, regularidades, etc. Os dois primeiros pontos são retirados de CORREIA (2005):

1) significa uma propriedade estatística da fonte, ou seja designa a quantidade de informação que poderá ser transmitida, mas ainda está retida na fonte emisora. Refere-se, portanto a uma espécie de informação potencial agregada ao maior ou menor grau de escolha/seleção, mas também as probabilidades envolvidas nessas escolhas.

2) significa uma quantidade de informação já selecionada, que foi de fato transmitida e recebida. Neste caso, a informação não estaria desatrelada do significado, já que ela implica

\footnotetext{
${ }^{12}$ Simondon, G. L'Individu et as Génèse Physico-Biologique. Épiméthée. Paris: Presses Universitaires de France, 1964.
} 
em imposições de ordenamento prévio. A informação é percebida como algo que possui uma regularidade, uma localização, um domínio definido, um estereótipo determinado pelo qual a informação se distingue do acaso puro. Por esta via, a entropia pode ser vista como a medida negativa do significado de uma mensagem.

Adicionalmente, e conforme BUCKLAND (1991), existem ainda outros três sentidos de informação, a saber: 3) Informação como processo (ex. como aquele que envolve a relação entre evidência e proposições); 4) Informação como conhecimento (ex. a identificação de uma regularidade implica em elevado grau de predição e controle) e, 5) Informação como "coisa" ou objeto (como no caso dos "artefatos" arqueológicos). E, deste último significado retira-se ainda, outra forma de compreensão: 6) a informação como representação ou como abstração da coisa ou objeto (o conceito de "lesma" em arqueologia).

Por fim, cabe um parêntese sobre a artificialidade das divisões adotadas, visto que qualquer análise deste tipo retira as questões de interconexão, complexidade e incerteza associada ao processo informacional. No entanto, foram utilizadas aqui com a finalidade de clarear algumas das relações e diferentes percepções envolvidas, com o propósito da formatação de modelo conceitual sobre os processos de transmissão de informações no raciocínio arqueológico (explicitado no item 2.2). A seguinte citação explora um caráter subjacente aos itens acima e demonstra um pouco da complexidade envolvidas em qualquer relação informacional

\footnotetext{
"Um objeto material determina suas qualidades relativas ao espaço, ao tempo, ao movimento e à sua organização - qualidade esta que se manifesta como entropia negativa, isto é, informação. Se a massa mensura os efeitos da gravitação e da força de inércia e a energia mensura o movimento, a informação, em sentido quantitativo, mensura a organização do objeto material. A matéria está ligada não só às características referentes a espaço, tempo e movimento, mas também à característica da organização. Matéria, espaço, tempo, movimento e organização estão em conexão recíproca." (Araújo, 1995 p.4 $)^{13}$
}

\subsection{A PERCEPÇÃo DA TEORIA INFORMACIONAL NO PENSAMENTO E INFERÊNCIAS ARQUEOLÓGICAS}

Do ponto de vista do histórico do raciocínio arqueológico, a perspectiva sobre o papel da informação nos processos de formulação de interpretações, explicações, hipóteses, etc.,

\footnotetext{
${ }^{13}$ Araújo, 1995 p.4 (Ciência da Informação) Vol 24 no1 - Artigos (site pdf)
} 
dependeu, sobretudo, da posição teórica adotada, seja esta de forma consciente ou inconsciente. Conforme M. Gándara podemos entender uma posição teórica através do conjunto de opções particulares tomada por membros de uma comunidade científica quanto à ontologia (tipo e característica das unidades de que falam suas teorias); a epistemologia (quanto à forma em que se posicionam frente ao problema do conhecimento e da relação realidade-consciência); a metodologia (relacionada a natureza e objetivos da prática científica, assim como os procedimentos de avaliação de hipóteses e teorias, entre outros); e as técnicas (que incluem os protocolos de observação e instrumentação e o conjunto específico de procedimentos práticos de obtenção e manipulação de dados). Por fim estas opções precisam ainda associar-se às propostas de teorias substantivas voltadas à solução de problemas específicos (GÁNDARA, 1981, p.61).

Considerando, no entanto, que a análise de todos os componentes vinculados às diferentes posições teóricas adotadas pela Arqueologia demandaria um trabalho que se distancia dos propósitos deste estudo, apenas serão apontados alguns aspectos comparativos para uma análise informacional.

Sob o ponto de vista da abordagem histórico-cultural nos Estados Unidos, deflagrada em especial por Franz Boas, que ao se opor ao evolucionismo cultural, argumentava entre outros, que as culturas são entidades únicas, entendidas sob seus próprios termos, não existindo padrões universais comparativos entre distintas culturas (TRIGGER, 2004). Tendo por base os pressupostos do relativismo cultural e do particularismo histórico, a abordagem histórico-cultural na Arqueologia teve por objetivo a observação das "normas" e do desenvolvimento histórico das culturas nativas. As mudanças, neste caso, foram vistas como produto de contatos ou influências entre culturas, (ou entre centros culturais e áreas periféricas) sendo explicadas a partir de conceitos como difusão e migração.

Assim, "contatos", "influências" e, notadamente "normas", estavam imbuídas da noção que a cultura consiste de "idéias" e, portanto, é um fenômeno mental. A invenção e a mudança eram percebidas como situações raras e a variabilidade cultural sendo produto principalmente de idéias transmitidas ou compartilhadas.

Por sua vez, à semelhança das descrições etnográficas da época, as culturas arqueológicas podiam ser definidas por conjuntos repetidos de tipos singulares, cujas similitudes e diferenças foram organizadas espacialmente por áreas geográficas (áreas culturais) e temporalmente, pelos períodos em que determinados "tipos diagnósticos" seriam compartilhados. Em resumo, caberia ao arqueólogo ordenar e comparar classificações e tipologias cujo objetivo final seria a "interpretação" da variabilidade organizada temporal e geograficamente. O problema de circularidade entre a seleção e organização de dados e a teoria que os explicava de antemão (migração, difusão, etc), bem como posições filosóficas que viam a própria teoria com desconfiança (priorizando, conforme Gándara, op cit. p.65, a 
recopilação de dados em campo), impedia uma perspectiva epistemológica sobre o assunto, ficando a discussão teórica focada quase que exclusivamente sobre a tipologia:

Desde el problema de lograr resultados replicables, y estandarización de la nomenclatura (cf. Mc Kern 1936), hasta la polémica en torno a la existência "real" de los tipos, o su status como "meros instrumentos" (cv. Ford Y su polémica con Spaulding) (GÁNDARA, op cit. p. 66)

Outras opções teóricas disponíveis à época pareciam estar reduzidas a formas ligadas à "Ecologia Cultural" de Steward $\left(1955^{14}\right)$ e ao "Materialismo Cultural" de White $\left(1959^{15}\right)$, cujas diferenças nas propostas explicativas sobre a questão da variabilidade cultural foram utilizadas por Binford para o desenvolvimento dos postulados da New Archaeology. Se ambos concordavam que as explicações requereriam leis gerais, Steward, ao contrário de White, creditava ao reporte das regularidades empíricas a capacidade de determinar tais leis. O ataque de Binford a esta posição "indutiva estreita" de Steward e a apreensão da concepção sistêmica de cultura de White remeteram o autor à adoção do modelo hempeliano de explicação e a aplicação do método hipotético-dedutivo na formulação e contrastação de hipóteses.

Ainda neste aspecto, dois pontos devem ser ressaltados dos postulados estabelecidos pela New Archaeology Americana. Um refere-se à percepção do registro como um fenômeno contemporâneo que preserva coisas do passado (embora como em BINFORD, 1983 p. 33, assinale que nosso conhecimento do passado não pode estar limitado pelo conhecimento do presente). Outro ponto é que tendo um referente no passado, este tipo de cultura material articula-se com um "sistema cultural total", de tal forma que teria condições de manter consigo informações sobre a operação de outros subsistemas.

A natureza pretensamente organizada (sistêmica) e intocada (fossilizada) deste registro implicou a princípio, no rechaço de toda e qualquer limitação informativa do material arqueológico havendo, no entanto, a necessidade de controlar aspectos de representatividade, certeza e significados feitos sobre este registro.

Esta argumentação contrasta radicalmente com as percepções da arqueologia tradicional sobre as limitações do registro arqueológico, que conforme Binford, em decorrência de uma concepção normativa de cultura (que criava uma dicotomia entre cultura-material e cultura espiritual ou não material) e de uma estratégia indutiva estreita, limitaria as possibilidades de conhecimento do passado àquelas classes de dados que conseguiram sobreviver. Assim

\footnotetext{
${ }^{14}$ Steward. J.. Theory of culture change. University of illinois Press. Urbana, 1955.

${ }^{15}$ White, L. The evolution of culture. McGraw-Hill. New York, 1959.
} 
tornam-se freqüentes os argumentos sobre a impossibilidade de conhecer o que falta no registro e, deste modo, jamais avaliar corretamente o que está presente, ou ainda, de como saber se uma generalização empírica está correta, quanto poderia haver evidências contrárias que podem ter sido perdidas? (ex. BINFORD, 1964, 1968). Esta limitação informativa está na base da recusa da arqueologia tradicional em fornecer explicações.

Por sua vez, Binford assinala que "os dados não falam por si mesmos" (BINFORD, 1968), e que mesmo que todos os pisos ocupacionais pudessem ter sido preservados, nada falariam sobre processos culturais e formas de vida passadas, a menos que fossem feitas as perguntas adequadas. Para ele, as limitações estariam associadas a pouca sofisticação metodológica e à carência no desenvolvimento de princípios capazes de determinar a relevância dos materiais arqueológicos como proposição explicativa. Sua visão de cultura como "conduta adaptativa" que serve como "meio extra-somático de adaptação de uma sociedade ao seu ambiente físico e social" (BINFORD, 1962, p. 218) implica que tal explicação se dê em termos de processos, compreendidos como "operação e modificação estrutural de sistemas" e, portanto, voltados à explicação das mudanças culturais. Propõe um conceito importante que permitira o uso de materiais arqueológicos para a contrastação de hipóteses ${ }^{16}$ sobre dinâmica cultural: a "estrutura arqueológica":

The formal structure of artifact assemblages together with the between element contextual relationships should and do present a systematic and understandable picture of the total extinct cultural system. (BINFORD, 1962, p. 219)

Em essência, a estrutura arqueológica reteria parte da organização do sistema cultural extinto e sua detecção ou isolamento se daria através da demonstração de associações e correlações consistentes intra e co-variações mútuas entre classes. A identificação de sua não aleatoriedade na distribuição de artefatos (identificada por meio de mecanismos estatísticos e requisitos específicos quanto à forma de obtenção) e suas associações conduziria à resultante do entendimento de atividades comportamentais específicas.

A estrutura arqueológica para Binford seria composta de três tipos de artefatos e suas associações, a saber: os itens ou objetos culturais (cultural items); os elementos ou feições culturais (cultural features) e os ecofatos (ecofacts). Cada qual compõe, em sentido estatístico, uma população com diferentes problemáticas de amostragem. Os objetos culturais comporiam entidades discretas e transportáveis, suscetíveis de serem estudadas,

\footnotetext{
${ }^{16}$ Outra proposição refere-se ao uso de analogias etnográficas como abordagem heurística, servindo não como fonte de conhecimento, mas sim fonte de hipóteses, cujo valor científico se daria apenas quando submetido a cuidadosa contrastação.
} 
independentemente da informação sobre sua proveniência, ou seja, de sua associação com a matriz deposicional. Por sua vez, as feições culturais representam unidades limitadas, isoladas qualitativamente, que exprimem relações entre dois ou mais objetos e tipos de matrizes, sendo a princípio, não transportáveis ${ }^{17}$ e não analisáveis formalmente. Por fim, os ecofatos representariam a classe dos materiais não culturais relevantes à compreensão da articulação entre cultura e ambiente. São de natureza composta, cujas distintas classes apresentam problemáticas próprias de amostragem e interpretação. Devido às inúmeras variáveis de observação e amostragem das estruturas arqueológicas, tornava-se necessário a adequação das estratégias e escalas de investigação,

Ya que lãs unidades de observación tienen una estructura jerárquica, (objetos, elementos, sitios, regiones), y que la mayoria de los problemas antropologicamente relevantes, tienen una escala superior a la de un sítio, Binford insiste en la necessida de adoptar como unidad de investigacion la región, para cuya delimitación establece criterios (GÁNDARA, op cit:76)

Finalmente, para demonstrar a presença de padrões de distribuição e organização no estudo da estrutura arqueológica, torna-se necessário a existência de controles sobre a representatividade da informação de forma a justificar o uso de estatística inferencial (controle de amostras) e de técnicas para a contratação das hipóteses (amostra aleatória e representativa da população estudada).

Esta perspectiva analítica da New Archaeology, conforme GÁNDARA (op cit p.80), tem se nutrido da compilação do trabalho de CLARKE (1968), cuja base de raciocínio advinha em parte da "Nova Geografia". Porém Clarke, apesar de adotar maciçamente o uso de modelos sistêmicos, afasta-se da New Archaeology, quando explicitamente rechaça o modelo de explicação binfordiano (CLARKE, 1972).

Por sua vez, CLARKE $(1972,1973)$ e DANIELS (1972) introduzem a perspectiva sobre as possibilidades de abordar os problemas de processamento de informação e classificação através do aprimoramento de uma Teoria de Informação Arqueológica. O enfoque estaria vinculado aos tipos de classes de informação que os métodos arqueológicos poderiam fornecer sobre o passado, e ainda, as limitações e obscuridades impostas pela natureza do registro e por expressões de linguagem. Clarke situa esta teoria no campo da "epistemologia arqueológica", que em conjunto com as teorias metafísicas (conceituais) e de raciocínio lógico, estariam dispostas em um nível mais abstrato que os conjuntos teóricos ligados às

\footnotetext{
${ }^{17}$ Esta característica emprestaria as feições culturais maior confiabilidade do que os objetos, pois não estariam tão suscetíveis a movimentações pós-deposicionais (sic).
} 
chamadas "teorias gerais", a saber, predepositional and depositional theory; postdepositional theory; retrieval theory; analitical theory; intepretative theory.

Uma proposta semelhante, que objetivou refinar e suplementar o modelo acima se refere ao enquadramento teórico de SULLIVAN (1978). Para ele, a construção de um modelo que especifique "como a informação do passado pode ser transmitida ao presente por meio dos vestígios materiais" (SULLIVAN, 1978 p.192) indica a preeminência dos seguintes tópicos:

(a) specify those past circumstances surrounding how and where information is likely to be mapped (that is, become represented) onto items, surfaces, and their relations; (b) specify the circumstances affecting the likelihood that the mapped information will be encountered in an archaeological situation; and (c) provide the conceptual tools to partition the properties of material remains in terms of the factors responsible for their production. (SULLIVAN, op cit. p.192-3)

Assim, similarmente a Clarke, coloca o modelo teórico de "transmissão de informação do passado" em um nível hierárquico capaz de conter três componentes teóricos da Arqueologia, que chamou de Formation Theory, Recovery Theory e Analytic Theory. No entanto, o ponto de discordância com os modelos de Clarke (1973) e Daniels (1972) situa-se na visão sobre as limitações do registro arqueológico como fonte de informações e na classe de informação capaz de ser transmitida.

Para Sullivan, ambos os autores limitam-se a considerar as sucessivas perdas informacionais sofridas pelo registro arqueológico ao longo do tempo, desde sua fase deposicional até a fase interpretativa do registro. Por sua vez, Daniels consideraria os objetos como elo entre passado e presente enquanto para Clarke seriam os "traços" observados nos vestígios materiais, as propriedades informacionais capazes de serem transmitidas de forma não ambígua. O autor então considera que não existem apenas perdas de informação no registro arqueológico, mas ganhos também (como quanto dos indicadores paleoambientais agregados ao registro sedimentar) (Figura 3), e que arqueólogos não estão limitados a pouca ou nenhuma informação, e muito mais, por uma abundância de informações. Por fim, apesar de considerar os traços como elementos importantes capazes de conter informações do passado, estes apresentam inúmeras fontes de ambigüidades e que deveriam ser tratadas através dos contextos associados à produção dos traços (interative context, depositional context, discard context; archaeological context) e os fatores que podem afetar estes contextos. 
Níveis de Informação

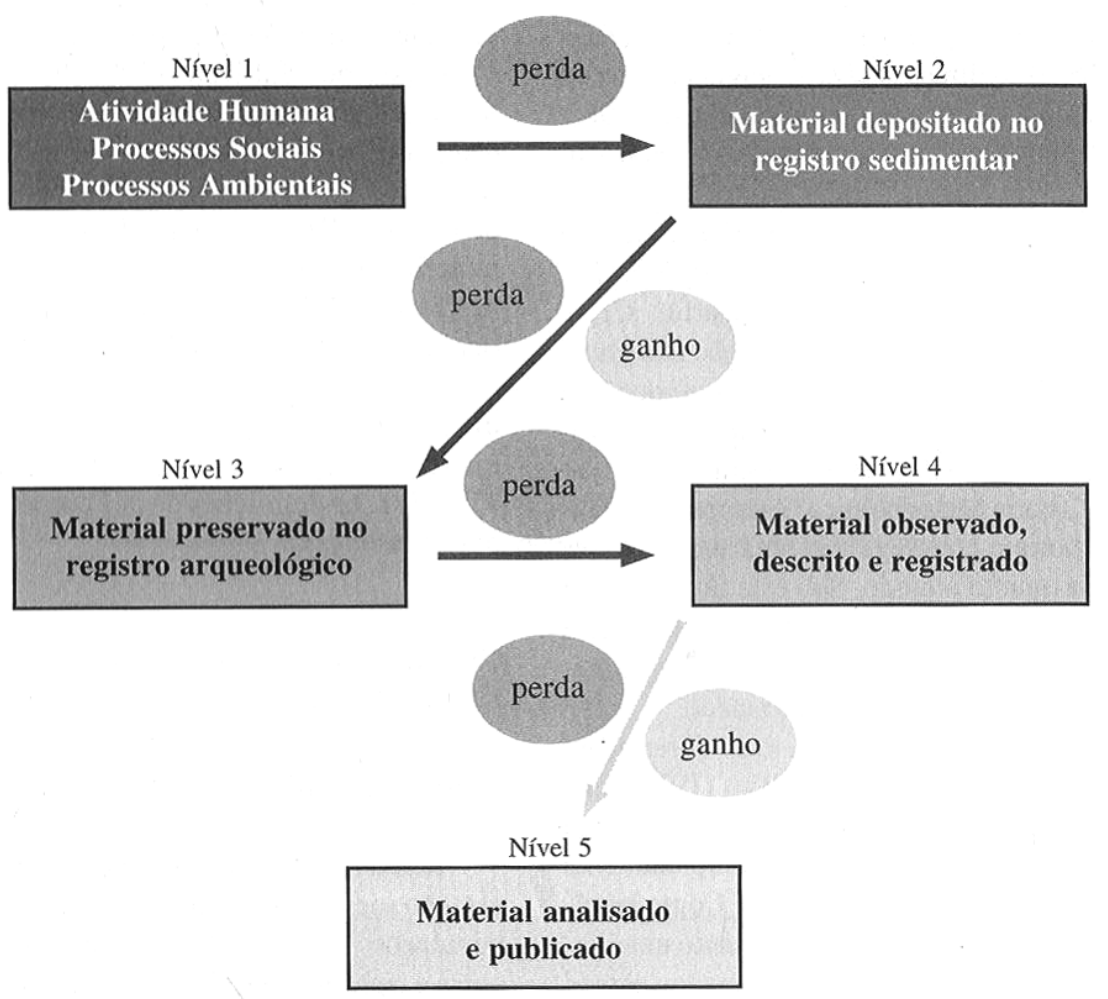

Figura 3: Diagrama representando os diferentes níveis de informação do registro arqueológico e suas relações gerais de perdas e ganhos informacionais (fonte: Araújo,1999, adaptado de Sullivan, 1978)

\subsection{O PROBlema dA "NÃo-INFORMAÇÃO": PROPOSTA PARA A ANÁlise E tRATAMENTO DA INCERTEZA EM ARQUEOLOGIA}

A perspectiva da aplicação de uma Teoria de Informação Arqueológica (CLARKE, 1973) inclui a elaboração de um modelo que especifique "como a informação do passado pode ser transmitida ao presente por meio dos vestígios materiais" (SULLIVAN, 1978). Entretanto, como pode ser visto no item introdutório do capítulo, a resposta a esta questão remete às diferentes percepções sobre o que é uma informação, qual seu papel e onde estaria contida, entre outros, o que incide sobre as necessidades de demarcação e ênfase no presente trabalho. Como um dos objetivos centrais desta tese está na análise e tratamento das fontes de informação e incerteza no raciocínio e práticas arqueológicas, não há como se deter apenas no tipo de informação supostamente "contida" nos vestígios materiais (informação como coisa, objeto), mas deve abranger também o potencial informativo e as redundâncias presentes na fonte (informação como emissor); os processos de ganhos e perdas informacionais (informação como processo), as características da informação selecionada e decodificada (informação como receptor) e, finalmente os processos de comunicação ligados aos propósitos e contextos de transmissão (determinando a informação como conhecimento). 
Outro ponto, a considerar refere-se à questão do que pode ou não ser informativo que remete ao pressuposto de que a informação é relacional (MORIN, 2005), situacional ou circunstancial (BUCKLAND, 1991), dependendo inclusive da disponibilidade de métodos e técnicas de coleta, registro e tratamento analítico (como exemplo, o caso de carvões arqueológicos antes e depois da inserção de métodos radiométricos de datação). Assim, para uma correta análise torna-se necessário determinar um sentido de contexto (CHADWICK, 2007), o que remete às questões e problemáticas a serem respondidas, o substrato teórico-metodológico inicialmente envolvido (perspectivas de método, proposições, hipóteses, etc) e que tipo de entidades e relação de entidades serão tratadas ou observadas.

Assim, para este tópico pretende-se analisar a questão das informações e incertezas advindas da relação entre sítios arqueológicos e meio natural, vistas não sob o ângulo dicotômico, mas sim, sob a perspectiva dialética. Neste sentido as relações de contraposição entre a tese (meio natural) e a antítese (sítios) irá corresponder a noção de evento ou conjunto de eventos (síntese). Quando observamos o registro arqueológico como evento dialético, podemos identificar uma problemática aqui denominada por "Problema da Não Informação", que como indicado no capítulo introdutório, refere-se à possibilidade de informações não relevantes (no sentido daquilo que não foi selecionado como dado ou evidência nos processos de inferência ou interpretação arqueológica), de conter fatores interferentes atuando sobre as informações selecionadas produzindo imprecisões e distorções no registro arqueológico.

Neste sentido, a Não-Informação (ou N-Info) é vista aqui como um problema de incertezas, derivado não apenas das características de formação do registro arqueológico, mas também das relações informacionais existentes nas sucessivas passagens entre níveis de informação (Figura 3) nos distintos campos teóricos da disciplina. Este ponto é importante, pois parte dos autores que tratam da estrutura teórica em Arqueologia acaba por focar cada campo (teoria formativa, teoria de recuperação, etc) de forma separada, dando menor ênfase às teorias de ligação entre esses campos. Assim, ao se concentrar no problema da $\mathrm{N}$-Info pretende-se prescutar alguns elementos, fatores e processos associados a esta "teoria de ligação" e que possibilite a inclusão da incerteza nos modelos inferenciais adotados em Arqueologia.

Quanto ao substrato teórico-metodológico, este procura o respaldo em modelos explicativos e interpretativos como da teoria pragmática de van Frassenn; nas teorias e métodos derivados da Ciência da Informação; das abordagens inferenciais vinculadas ao raciocínio abdutivo (que simularia o processo dialético nas ciências naturais, permitindo o estudo das mudanças) e por fim nas proposições de enfoque da Geoarqueologia, cujo 
campo de estudo é considerado propício à investigação do problema da $\mathrm{N}$-info entre sítios e meio natural, e nas possibilidades de seu tratamento.

Por fim, quanto ao tipo de entidades ou relação de entidades abordadas, ao conjunto de evidências, proposições e inferências, cujas relações lógicas perpassam um modelo sobre processos de transmissão de informações no raciocínio arqueológico. A fim de esclarecer a amplitude de significados associados ao termo "não-informação", e sua influência no processo de geração e transmissão de informações necessitamos de uma caracterização mais precisa do termo.

A idéia de uma não-informação em Arqueologia geralmente está associada, entre outros, às seguintes percepções: a) características de "ausência" de elementos ou estruturas, mas que são utilizadas no processo interpretativo (portanto, são informações); b) relativo às perdas informacionais derivadas de processos de deterioração físico-químico-biótica, procedimentos não apropriados de registro, escavação, etc, c) viés informacional decorrente de problemas de consistência, insuficiência, representatividade amostral, etc.; d) informação com nenhum significado arqueológico imediato, valor acessório, sem relevância, resíduoruído, etc.; e) informação-incerteza potencial associado a sistemas não acessíveis ou despercebidos, ou ainda; f) relações complexas, não organizadas (aleatoriedade), não preditivas, não comunicáveis.

Por sua vez, CLARKE (1984) pontua outra característica do que considera "não informação". Esta seria produto da seleção não intencional de atributos e que permanece como algo "agregado" aos dados e informações relevantes, mas cuja influência poderia ser eliminada com adequado tratamento estatístico:

\footnotetext{
"algunos atributos fueran regular y cuidadosamente seleccionados por algún motivo, y éstos nos aportan uma infomación y dados arqueológicos; otros no fueron normal ni intencionalmente seleccionados y producen uma "interferência parasita" o uma "noinformación". La separación entre estas dos clases de atributos depende fundamental y arbitrariamente de las suposiciones del observador, pero el término "regular e intencionalmente" selecionado apunta un posible recurso a la estadística para el tratamiento de agregados de artefactos similares." (Clarke, 1984, p. 12) [grifo nosso]
}

Considerando as diferentes percepções acima, no presente trabalho a não-informação será vista a partir da ótica dialética e posicionada em três momentos (ou "eventos"): I) como elemento relacional inerente ao reconhecimento do novo e na seleção das informações ou contextos considerados relevantes atuando, portanto, como tese, classe de contraste universo de escolhas, ou mesmo redundância; II) na conversão da síntese ou unidade de contrários, a positividade da informação relevante (transformadora, antítese) emerge como negação da negação, pois "não anula aquilo que nega, ela transforma-o, forma-se e 
deforma-se nele" (MORIN, 2005 p. 361), ou seja, à informação relevante, ao ser "transmitida" ao nível de síntese, traz consigo a redundância da fonte (ou seja, ao aceitar aquilo que foi negado, a síntese nega o que foi negado); III) como o movimento anterior não desaparece, o descuido comum está no uso das informações selecionadas, considerando que as informações não selecionadas têm caráter apenas de "redundância" e "ruído" e portanto dispensáveis nas análises subseqüentes. No entanto, deve-se ter em mente que a redundância na teoria informativa contém tanto (a) elementos prescindíveis (que não afetam a efetividade da comunicação nem a decodificação da mensagem) quanto (b) elementos imprescindíveis (estruturantes, códigos, conhecimentos prévios), ou seja, necessários para a exatidão da mensagem e mesmo para sua ocorrência. E finalmente, seja na redundância prescindível quanto na imprescindível, poderão existir informações ou (c) elementos agregados, "interferências"que representam as incertezas trazidas do processo anterior (tese-antítese), capazes, portanto de continuar a interagir no processo informacional, mesmo não sendo informação processada.

A percepção da existência desta informação agregada, co-participante dos eventos I, II e III, é chamada aqui, portanto de Não-Informação ou N-info. A N-info quando identificada e tratada apenas reduz os vieses informacionais, jamais desaparece por completo.

Dito de outro modo, a $\mathrm{N}$-Info corresponderia a qualquer conjunto de informações que de algum modo tenha co-participado do processo inicial de geração/seleção de informações relevantes (ou seja, faziam parte da condição de seleção) mas que, na passagem para diferentes níveis analíticos/generalizantes, não foram reconhecidos como significante e, portanto, tratados com "ruído" no processo informativo-comunicacional, muito embora contenham ainda variáveis agregadas capazes de interferir nas característica da informação selecionada.

Como exemplo, em uma pesquisa sobre padrão de assentamento foi detectado uma concentração de sítios líticos associados a caçadores coletores (proposição, conceitos) em determinado compartimento ambiental (topos de colinas) existente na área de pesquisa. Esta constatação (evidência) foi dada a partir de prospecção sistemática, ou seja, inferência probabilística. Com base nisto chega-se a seguinte hipótese: Existe uma preferência de grupos caçadores-coletores por topos de colinas na área de pesquisa e esta preferência representa um padrão a ser considerado. Esta inferência hipotética, carrega consigo redundâncias da fonte, ou seja, (a) elementos prescindíveis (portanto, que aparentemente não afetariam a efetividade da comunicação), como a relação percentual entre as colinas e outros compartimentos; áreas onde não ocorrem sítios líticos; representatividade da amostragem em termos de espaçamento e profundidade das sondagens (tida como conhecida de antemão); fatores de uso do solo; dinâmica da paisagem; etc ; (b) elementos imprescindíveis (estruturantes, conhecimentos prévios), 
definição de sítios líticos associados a caçadores coletores; relação de ocorrências com outros sítios líticos e não líticos fora da área onde foi identificada a concentração; etc e; (c) elementos agregados (variabilidades, ambigüidades, imprecisões, distorções, incompletudes e incertezas trazidas no processo de síntese): tais como, outras concentrações líticas que podem estar dispostas nas planícies fluviais sob sedimentação; erosão pronunciada em topo de colinas pode ter favorecido descoberta de sítios neste compartimento; alcance e margem de erro associada à amostragem; o universo considerado não é representativo; assim a concentração pode ser anômala e não indicativa de padrão de assentamento ou ainda, variações na distribuição de topos de colinas e outras variáveis, a cronologia dos sítios é ambígua em termos de advogar contemporaneidade ou não dos sítios, etc.

A idéia do conceito de $\mathrm{N}$-info justifica-se pelos seguintes pontos:

- Forma de inserir a incerteza e complexidade nas estruturas de raciocínio utilizadas na arqueologia, visualizando os processos de organização da informação como processos dialéticos. Assim, seja através de inferências dedutivas, indutivas ou abdutivas existirá uma seleção e ordenamento que suprime a complexidade dos fenômenos, mas que parte desta complexidade ficará agregada às informações selecionadas, na forma de imprecisões, vieses, incertezas e ambigüidades;

- demonstrar o caráter essencialmente contraditório e relacional das informações tratadas em arqueologia, e que parte das incertezas agregadas jamais serão eliminadas, mas apenas tratadas por "controles" Infomacionais. Por sua vez, as ambigüidades só poderão ser controladas pela explicitação máxima dos contextos considerados.

- possibilita ir nas "causas" de algumas das incertezas através da retrodição dos processos analíticos/generalizante já efetuados (tese-antítese=síntese/tese...), em busca das variabilidades associadas às condições e contextos de seleção.

Ao considerar o conceito de $\mathrm{N}$-Info acima propõe-se o seguinte modelo dos processos de transmissão de informações no raciocínio arqueológico (Figura 4), que toma por base as relações informacionais-dialéticas envolvidas na própria percepção e seleção do fenômeno (portanto, também contraposto a um "não fenômeno"). As relações entre informação e não informação (no sentido de selecionada e não-secionada) ocorrerão a partir da apreensão ou abstração do fenômeno, seja como descrição-dado (informação como coisa) ou como definição-conceito (informação como representação). Por sua vez, tais relações seriam mais expressivas (e com maior redundância) na passagem dos dados e conceitos para evidências e inferências (vinculadas às informações como fonte ou como processo). A resultante dessas relações, entremeada por um contexto de transmissão (canal e 
receptor), determinará a informação selecionada à "ação", desencadeando um processo de comunicação (Informação como conhecimento).

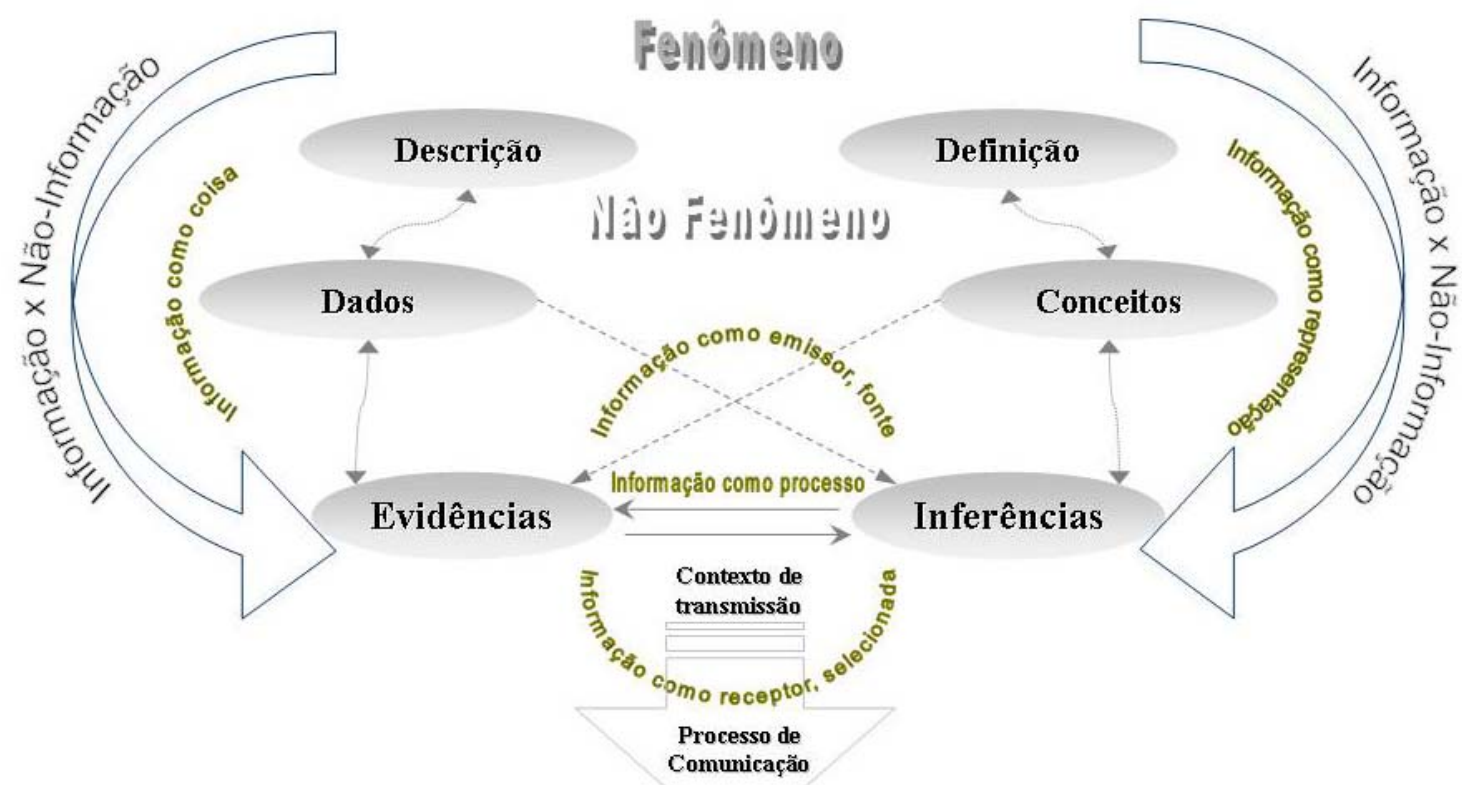

Informaçăo como conhecimento

Figura 4: Esquema proposto para o enquadramento dos processos de transmissão de informações no raciocínio arqueológico

Neste modelo, tanto as evidências e inferências, quanto a relação entre evidências e inferências, carregam consigo $\mathrm{N}$-info associada principalmente a dois tipos de fatores: 1) INCERTEZAS DA FONTE e; 2) INCERTEZAS DO PROCESSO

Quanto aos métodos de tratamento dessas incertezas, será dado especial interesse aos modelos de representação e tratamento das incertezas de processo, ou seja, onde serão definidas a informações de interesse direto na resolução de problemas. Esses métodos são derivados da Ciência da Informação e relacionam-se a sistemas baseados em conhecimento. Conforme Uchoa et al.(1998:1),

\footnotetext{
Existem vários modelos formais disponíveis para o tratamento de incertezas; apesar disso, muitas vezes o tratamento da incerteza em sistemas baseados em conhecimento tem sido feito através de abordagens ad hoc, baseadas em representações e combinações de regras que não estão subsidiadas por uma teoria bem fundamentada e tampouco têm o respaldo de uma semântica bem definida.
}

Para Santos et al (2003, sn) a incerteza, é gerada pela imperfeição da informação (imprecisão, conflito, ignorânica parcial ou total, etc) sobre a qual se tem que basear para uso ou tomada de decisão em uma determinada situação. Assim a qualidade das decisões ou usos dependerão inicialmente da própria informação fornecida ou recuperada. Neste 
sentido a qualidade da informação utilizada poderá variar de perfeita (traduz exatamente o que queremos saber) a completamente imperfeita. Por sua vez, a qualidade da decisão também dependerá do modelo de representação ou tratamento dado à informação disponível, onde para cada tipo existirá possivelmente um modelo formal mais adequado.

Ainda segundo Uchoa et al (op cit p.):, dos modelos mais conhecidos de tratamento de incertezas, encontram-se:

- $\quad$ regra de Bayes (Pearl,1982) ${ }^{18}$

- $\quad$ regra de Bayes modificada (Duda et al.,1976) ${ }^{19}$

- fator de certeza (Gordon \& Shortliffe,1984) ${ }^{20}$, baseada em teoria da confirmação

- teoria de Dempster-Shafer (Dempster, 1967 21 ; Shafer, 1976 ${ }^{22}$ )

- teoria da possibilidade (Zadeh, 1978) ${ }^{23}$

- raciocínio default (Reiter, 1980) ${ }^{24}$

- $\quad$ teoria de endorsements (Cohen,1985) ${ }^{25}$

- teoria de conjuntos aproximados (Pawlak, 1982) ${ }^{26}$

Assim, para uma informação de cunho probabilista será mais adequado a utilização de modelos que lidem com estas características, como a teoria de probabilidade condicional (Bayes) ou de combinação de evidências (Dempster-Shafer); no caso de informações vagas ou imprecisas será considerado, por teorias de conjuntos nebulosos ou conjuntos de aproximação; informações possibilista, por teoria das possibilidades, etc. Entretanto, determinadas informações (ex. as incertas, inconsistentes, incompletas, etc) podem se utilizar de diferentes modelos formais para seu tratamento, como probabilidades, possibilidade e evidência (Santos et al, op cit).

Tais abordagens têm sido amplamente utilizadas em diferentes campos científicos como na geologia (ex. ROSTIROLLA et al., 1998; ROSTIROLLA, 1999; SOARES \& PERDONCINI, 1999;

\footnotetext{
${ }^{18}$ Pearl, J. Reverend Bayes on inference engines: a distributed hierarchical approach. In: Proceedings of the Second National Conference on Artificial Intelligence, Pittsburgh, PA, 1982, p. 133-136.

19 Duda, R. O.; Hart, P. E.\& Nilsson, N. J. . Subjective bayesian methods for rule-based inference systems. In: AFIPS Conference Proceedings, N.Y., June 1976, p. 1075-1082.

${ }^{20}$ Gordon, J. \& Shortliffe, E. H. The Dempster-Shafer Theory of Evidence. In: Rule-based expert systems. New York, Addison-Wesley, 1984.p. 272-292.

${ }_{21}$ Dempster, A. P. Upper and Lower Probabilities Induced by a Multivalued Mapping. Annals Mathematics Statistics, 38, 1967, p. 325-339.

${ }^{22}$ Shafer, G. A mathemathical theory of evidence. Princeton, Princeton University Press, 1976.

${ }^{23}$ Zadeh, L. A. Fuzzy Sets as a Basis for a Theory of Possibility. In: Fuzzy Sets and Systems 1, 1978, p 3-28.

${ }^{24}$ Reiter, R. A Logic for Default Reasoning. Artificial Intelligence 13, 1980, pp. 81-132.

${ }^{25}$ Cohen P.R. 1985. Heuristic reasoning about uncertainty: an artificial intelligence approach. Boston, Pitman Advanced Publishing.

${ }^{26}$ Pawlak, Z. Rough sets. International Journal of Computer and Information Sciences , 11(5), 1982, p. 341-356.
} 
SOARES ET AL, 2002) em SIG e cartografia (ex. MALPICA ET AL., 2002; MALPICA ET AL., 2007), ecologia (ex. ANGELINI, 2002), entre outros. No entanto, conforme Santos et al (2003) a decisão pelo melhor método irá depender do modelo e sua capacidade em tratar a informação disponível, onde para cada tipo de informação, existirá um modelo formal mais adequado.

Tendo em vista as proposições da presente tese o modelo que aparenta uma melhor adequação ao tipo de informação a ser utilizada, as limitações informacionais e os resultados pretendidos, refere-se ao teorema de Bayes (probabilidade condicional) e sua derivação mais conhecida, a teoria Dempster-Shafer (esta também conhecida por teoria da evidência).

Ambos os modelos, conforme Nassar, (2007 p.4) são traduzidos por métodos numéricos de representação da incerteza, onde no teorema de Bayes é utilizada uma estrutura rigorosa de representação de eventos aleatórios, aonde a probabilidade de um evento ocorrer assume valores de 0 a 1 , valor este alcançado por funções de distribuição de probabilidade. Representa a incerteza por aleatoriedade, não sendo possível prever totalmente o que acontecerá num novo caso, mesmo diante do conhecimento estocástico de casos anteriores do domínio de aplicação. Por sua vez, a teoria da evidência (Dempster-Schafer) apesar de representar a incerteza de forma semelhante ao teorema de Bayes, seu raciocínio é feito com medidas de crença, obtidas por meio de funções de crença por regras de combinação de evidências ou corpos de evidência, de modo a gerar uma única função de crença.

Quanto ao método bayesiano, este é capaz de computar a probabilidade de um dado evento, dado um conjunto de observações, onde:

$\mathbf{P}\left(\mathrm{H}_{\mathrm{i}} \mid \mathbf{E}\right)$ a probabilidade que a hipótese ou evento $\mathrm{H}_{\mathrm{i}}$ seja verdadeira dada a evidência $\mathrm{E}$.

$\mathbf{P}\left(\mathbf{E} \mid \mathbf{H}_{\mathrm{i}}\right)$ a probabilidade que a evidência $E$ será observada se a hipótese $\mathrm{H}_{\mathrm{i}}$ for verdadeira.

P $\left(\mathbf{H}_{\mathrm{i}}\right)$ a probabilidade "a priori" que a hipótese $\mathrm{H}_{\mathrm{i}}$ é verdadeira na ausência de qualquer evidência específica.

k o número de hipóteses possíveis.

O teorema de Bayes é formulado como:

$$
P\left(H_{i} \mid E\right) \equiv \frac{P\left(E \mid H_{i}\right) P\left(H_{i}\right)}{\sum_{J=1}^{k} P\left(E \mid H_{i}\right) P\left(H_{J}\right)}
$$

Uma modificação desta regra é a possibilidade de inclusão de novas evidências $\left(E_{n}\right)$ e evidência anteriores $\left(E_{a}\right)$, em relação a um dado momento do processo (GORDON, J. \& SHORTLIFFE, 1984): 


$$
P\left(H_{i} \mid E_{n} \cup E_{a}\right)=\frac{P\left(E_{n} \mid H_{i} \wedge E_{a}\right) P\left(H_{i} \mid E_{a}\right)}{\sum_{J=1}^{k} P\left(E_{n} \mid H_{j} \wedge E_{a}\right) P\left(H_{j} \mid E_{a}\right)}
$$

Em ambos os sentidos, esta regra admite que a ocorrência de uma evidência ( $E)$ modifica a probabilidade prévia de ocorrer um evento, num espaço determinado, por um fator igual à probabilidade da existência de E dada à ocorrência do evento (Soares, 2002:62)

Através da probabilidade a priori, se permite incorporar o conhecimento prévio na forma de imagens de probabilidade, permitindo que esta varie de um local para outro.

Por sua vez, algoritmos ou relações estatísticas entre evidências e eventos já conhecidos podem inserir probabilidades a posteriori a partir da entrada de um padrão $\mathbf{X}$, ou da verificação das relações a partir de um modelo conhecido (Giacinto et al., 2000).

O resultado de uma determinada coleta de informações é a elaboração de uma distribuição de probabilidades que expressa relações condicionantes entre conhecimentos prévios e a posteriori, permitindo a incorporação de dados gerados a partir de métodos analítico/estatísticos (como média, desvio padrão, etc) e do conhecimento prévio do analista/ especialista da área de estudo. Todavia, tão importante quanto indicar a probabilidade de uma informação resultante de sistemas baseados em conhecimento, é conhecer o grau de certeza e incerteza associada a essa informação.

Quanto ao método de Dempster-Shafer a informação derivada de uma fonte de conhecimento a respeito do valor real de uma variável $x$ definida no universo da proposição ou discurso $\mathrm{X}$, é tratada como um corpo de evidência sobre $\mathrm{X}$ :

"Um corpo de evidência é caracterizado por um par $(F, m)$, onde $F$ é uma família de subconjuntos de $\mathrm{X}$ (isto é, $\mathrm{F} \subseteq 2^{\mathrm{X}}$ ), e a função de alocação de massa $\mathrm{m}$ é uma aplicação de $2^{x}$ no intervalo [0,1], tal que $m(A)>0$ se e somente se e $A \in F$. Cada elemento é chamado elemento focal, e $m(A)$ se refere à evidência relativa a $A$ unicamente (e não aos subconjuntos de $A$ ). Nesta teoria, a incerteza ligada ao evento $A \in 2^{x}$ é medida através de duas funções Bel: $2^{\mathrm{X}} \rightarrow[0,1]$ e Pl: $2^{\mathrm{X}} \rightarrow[0,1]$, definidas por:

$$
\begin{aligned}
& \operatorname{Bel}(A)=\sum_{B \subseteq A} m(B) \\
& P l(A)=\sum_{B \cap A \neq \phi} m(B)
\end{aligned}
$$

A função de credibilidade Bel mede a que ponto as informações fornecidas por uma fonte sustentam A. A função de plausibilidade PI mede a que ponto as informações dadas por uma fonte não contradizem $A$. As funções de credibilidade e plausibilidade estão ligadas pela relação: 
$\operatorname{Bel}(\mathrm{A})=1-\mathrm{Pl}(\mathrm{A})$

Neste situação "a confiança representa o total a ser suportado pela hipótese, e será tirada da determinação da probabilidade básica (DPB) de todos os subconjunto que podem ser formados a partir deste a hipótese, isto é: $\operatorname{Bel}(A)=\Sigma_{m}(B)$ onde $B \subseteq A$ "

Isto equivale a dizer que quanto mais se aumenta à evidência sobre uma hipótese, menor se torna à plausibilidade da hipótese contrária. Por sua vez, a plausabilidade demonstra o grau que uma dada hipótese não pode ser descartada." (Santos et.al. (2003 s/p.) :

No conjunto, tais métodos estão voltados à atribuição de probabilidade básica (basic probability assignement) e ao tratamento dado à combinação de evidências. Conforme Soares \& Perdoncini (1999) este método pode ser adequado para casos onde não se dispõe de um banco de informações com significado estatístico ao qual se possam inferir as diferentes probabilidades para as diversas evidências.

Entretanto, considerando cada evidência e sua relação observacional lógica ou genética com a proposição, num domínio conceitual, baseado em informações já consolidadas na literatura, torna-se possível atribuir valores para o poder da evidência como confiança na relação entre a evidência e a proposição. Este valor numérico alocado à incerteza é relativo a uma situação particular e é obtido por uma análise cuidadosa da situação, das semelhanças e diferenças existentes entre diferentes casos, e não com base em uma análise de distribuição de freqüência (Soares \& Perdoncini, 1999:309).

Mas especificamente sobre a Teoria de Dempster-Shafer (TDS) conforme Gordon \& Shortliffe (1984), sua formulação foi motivada principalmente devido a problemas encontrados na modelagem da incerteza usando métodos puramente probabilísticos. Sua vantagem está na habilidade de modelar o "afunilamento" de hipóteses à medida que se acumulam evidências refletindo, por exemplo, o raciocínio utilizado em diagnósticos. Conforme Uchoa et al, (op cit),

Uma vez que a TDS atribui valores de crença a subconjuntos e a cada elemento do conjunto de hipóteses, essa teoria tem condições de refletir mais precisamente o processo de acúmulo de evidências. Além disso, a TDS permite que funções de crença possam ser combinadas, produzindo novas funções de crença num procedimento que independe da ordem na qual as evidências surgem, mas que, entretanto, exige que as hipóteses primitivas sendo consideradas sejam mutuamente exclusivas e exaustivas. A partir destas hipóteses primitivas (também denominadas singletons, ou unidades, por serem conjuntos unitários), é possível construir hipóteses mais elaboradas que não são mutuamente exclusivas ou exaustivas. (...) A partir de uma única coleção de evidências, usando a TDS, vários conjuntos alternativos de hipóteses podem ser derivados. A cada um desses conjuntos está associado um intervalo de confiança chamado de intervalo de crença. A 
TDS permite que, quando da determinação da validade de uma determinada hipótese, possam ser consideradas todas as informações disponíveis. (Uchoa et al, op cit, p.4).

Devido à robustez desses métodos e sua aplicações cada vez mais pertinentes em estudos de diagnósticos, exploratórios, levantamentos geológicos e ecológicos, mostra-se como ferramenta importante para a pesquisa em arqueologia, e mais especificamente, em geoarqueologia. Contudo antes de apresentar a sua aplicabilidade em abordagens geoarqueológicas convém explicitar que tipo de relações lógico-formais podem surgir entre evidências e proposições (inferências) a fim de discriminar os principais condicionantes de raciocínio probabilístico envolvidos na análise de incertezas e na determinação de alvos (modelagem exploratória, por exemplo).

\subsubsection{Relações formais entre evidências e inferências: os condicionantes do raciocínio probabilístico na análise de incerteza}

Para Soares (2000), que trata do problema das incertezas no raciocínio geológico, na derivação de um conhecimento científico novo [equivalente à informação processada e selecionada] pode-se trabalhar com três tipos fundamentais de relações lógicas entre uma base conceitual prévia e um conjunto de dados ou fatos.

i. inferência abdutiva - Dado um conjunto de evidências (S) indicadoras de algumas proposições ( $P$ - objeto indefinido pertencente a um conjunto finito de objetos possíveis) busca-se qual destas é mais esperada como verdadeira (ex. diante de uma concentração de sítios arqueológicos (S), qual a hipótese detém a maior probabilidade de explicar o padrão (P) observado). Ou seja, verifica quais das proposições permitidas ou potenciais tem mais probabilidade ou maior grau de atendimento aos pré-requisitos-condições necessárias (discriminada em relação a um grupo de preposições onde há um menor grau de atendimento). Neste tipo de inferência é possível avaliar a probabilidade de cada proposição, sendo que as evidências se constituem as condições necessárias para seu maior ou menor atendimento;

ii. Inferência dedutiva - Dada uma determinada proposição $(P)$ busca-se em um conjunto de evidências, qual a expectativa de confirmar a proposição como verdade (ex. diante de uma determinado tradição arqueológica $(P)$, busca-se em um conjunto de vestígios (S), qual a expectativa dos mesmos em pertencer a essa tradição). Este procedimento procura verificar o quão suficientes podem ser essas evidências como indicadoras de verdade da proposição. O raciocínio permitiria também avaliar a incerteza ou a ambigüidade da conclusão, principalmente através da inclusão de novas variáveis (evidências-informações); 
iii. Inferência indutiva - Dada uma série de observações particulares procura a generalização da relação entre uma dada evidência $(E)$ e uma proposição $(P)$. O raciocínio se utiliza das observações particulares em que a proposição se verifica, como critério de identificação da verdade da relação, para o caso em geral (ex. diante da constatação de inúmeros sítios bem preservados $(\mathrm{P})$ em cavernas, toda a caverna (E) é um indicativo da ocorrência de sítios bem preservados). Nesta situação, dada a Evidência $(E)$ esta é necessária e suficiente para a proposição se verificar.

Os exemplos arqueológicos associados a esses raciocínios já permitem verificar que em todos eles poderão ocorrer as primeiras incertezas ou dúvidas quanto à própria existência de $E, S$, ou $P$, ou seja, a possibilidade de algum elemento não existir ou ser falso (como em "i", a possibilidade da concentração (S) não existir; ou em "ii" de ser falso o conceito de tradição arqueológica $(P)$; ou em "iii" que a relação direta entre cavernas $(E)$ e sítios preservados (P) não exista). Ou ainda, poderão existir condições excludentes do tipo "para todo $S$ tem-se -P" (todo o $S$ não é $P$ ) ou negativas do tipo "para todo $-S$, tem-se P" (todo não $S$ é $P)$.

Por sua vez, pode-se depreender dos diagramas de Venn apresentados por Soares (op cit, p. 82), (Figura 5), que se considerarmos um espaço probabilístico onde o objeto (proposição) está presente como subconjunto $(P)$ e a evidência está presente como outro subconjunto (S), a validade (V) ou não (-V) da relação entre os subconjuntos obedecerá a determinados condicionamentos de raciocínio (por silogismo). Tais estruturas, no entanto, também não dão conta das incertezas, tais como aquelas derivadas da presença de evidências contraditórias ou ambíguas em relação à validade ou não de $P$, ou ainda, da imprecisão associada à determinação dos limites de $\mathrm{S}$ ou $\mathrm{P}$.

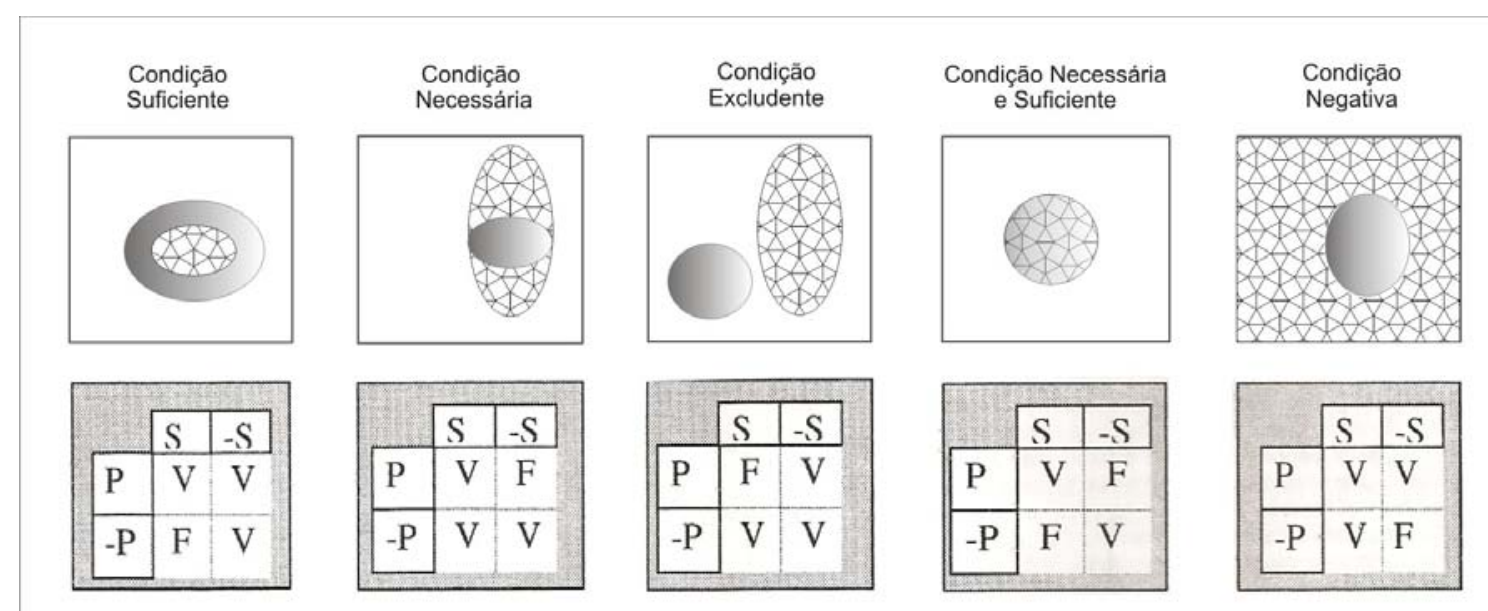

Figura 5: Possíveis relações entre evidência e objeto (proposição) e condicionamentos de raciocínio por silogismo, conforme Soares (2000, adaptado). No diagrama Venn acima: quadrado = espaço probabilístico; circunferência cinza $=$ espaço onde o objeto está presente $(P)$ e; cincunferência hachurada= espaço onde a evidência está presente. 
Em Soares e Perdoncini (1999:307) "Tanto a descrição de fatos observacionais (p. ex. a observação de uma propriedade descritiva) ou dados (p. ex. uma determinação analítica), como os conceitos ( $p$. ex. falha, granito, calcita) são imprecisos e incompletos". Da mesma forma, os argumentos voltados ao diagnóstico ou a determinação de uma proposição ou outra, não são inequívocos ou não ambíguos. Assim, na aplicação de conceitos, na predição de objetos como estratégia de busca (ex. recursos minerais), na previsão de eventos, análise de risco, etc, trabalha-se com diversas fontes de incerteza.

Torna-se necessário, então, abrir espaço nas estruturas de raciocínio para considerar ao menos, três tipos de incerteza: 1) aquela associada à evidência ( $E$ ou $S$ ); 2) associada à proposição ou hipótese $(\mathrm{P}$ ou $\mathrm{H})$; 3) associada à relação entre evidência e proposição (Soares, op cit, p. 86).

Sobre o primeiro tipo considera que quando há uma incerteza em determinada observação ou experimentação que revele uma evidência, poderá haver uma confiança (c) em nossa discriminação, uma imprecisão (i) na observação e ainda uma possibilidade (n) de que esta evidência não exista.

Quanto à incerteza conceitual associada a uma proposição (ou inferência), as imprecisões referem-se ao conteúdo estabelecido pela definição do conceito ( $P c=P$, onde c é a confiabilidade no conceito), feita com maior ou menor clareza, com certo campo de aplicação e certa identidade descritiva ou genética. Assim, também se admite que a perda de identidade descritiva de um conceito pode implicar em dúvida sobre se a realidade pertence ou não pertence ao conceito ( $P a=P,-P$, ou seja $P$ ambíguo) ou ainda, a possibilidade de estar incerta a definição adotada $(P n=-P$, onde $n$ é possibilidade que ela não exista).

Finalmente, outra fonte de incerteza (a incerteza relacional) refere-se "aquela associada a validação da relação entre um estado da evidência e um estado da proposição, podendo-se admitir as seguinte avaliações:

"1) a validade ou confiabilidade (c) nas premissas maiores, representadas pelos argumento de que a evidência observada $S$ é verdadeira e implica que $P$ seja verdade ( $S$ confirma $P$ ) ou que P seja incerto (S implica P ou - P) ou que P seja falso (S implica em -P);

2) a negação (n) nas premissas maiores representada pelos argumento de que se $\mathbf{S}$ é falso, e $P$ é verdadeiro (- $S$ imlica em $P$ ), ou $P$ pode ser falso ou verdadeiro ( $-S$ implica em $(P,-P)$ ou ainda $P$ é falso (-S implica em $-P$ ).

3) o complemento de $\mathrm{C}+\mathrm{N}$, a ambigüidade (a) nas premissas maiores representada pelo argumentos de que tanto existindo ou não a evidência, a proposição é verdadeira ( $S$, -S, implica em $P$ ), sendo neste caso $P$ independente de $S$, ou a proposição é indefinida ((S,-S) implica em $(P,-P)$ ou ainda a proposição é falsa ((S, $-S)$ implica em $-P)$. 
A representação da estrutura de raciocínio para as quais podemos avaliar a confiabilidade na afirmação (c), na negação (n) e na ambigüidade (a) fica constituída de 9 premissas maiores ou regras "R" (Quadro 2).

Quadro 2: Representação das 9 premissas (Regras) entre $S$ e $P$ e as avaliações de confiabilidade (c), negação (n)e ambigüidade (a) da Relação tipo "S então P" (constituindo 27 premissas menores)

\begin{tabular}{|c|c|c|c|c|c|}
\hline & & & \multicolumn{3}{|c|}{ Imprecisão na Evidência } \\
\hline & & & S & S,-S & $-S$ \\
\hline \multirow{3}{*}{\multicolumn{2}{|c|}{ 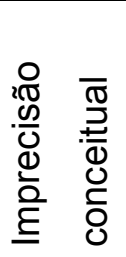 }} & $P$ & $\mathrm{R}(\mathrm{c}, \mathrm{a}, \mathrm{n})$ & $R(c, a, n)$ & $R(c, a, n)$ \\
\hline & & $P,-P$ & $\mathrm{R}(\mathrm{c}, \mathrm{a}, \mathrm{n})$ & $\mathrm{R}(\mathrm{c}, \mathrm{a}, \mathrm{n})$ & $\mathrm{R}(\mathrm{c}, \mathrm{a}, \mathrm{n})$ \\
\hline & & $-\mathrm{P}$ & $\mathrm{R}(\mathrm{c}, \mathrm{a}, \mathrm{n})$ & $\mathrm{R}(\mathrm{c}, \mathrm{a}, \mathrm{n})$ & $R(c, a, n)$ \\
\hline
\end{tabular}

As incertezas nas premissas maiores podem ser expressas em termos de probabilidades condicionais conforme o Teorema de Bayes, já que este método é capaz de computar a probabilidade de um dado evento $(P)$, dado um conjunto de observações $(E)$. Neste sentido temos:

PROBABILIDADE DE P DADO E:.....

PROBABILIDADE DE P DADO $\mathrm{nE}: . . .$.

PROBABILIDADE DE P DADO E,nE:..

PROBABILIDADE DE nP DADO E: ...

PROBABILIDADE DE nP DADO E,nE:.

PROBABILIDADE DE nP DADO nE: ..

PROBABILIDADE DE P,nP DADO E:..

PROBABILIDADE DE P,nP DADO E,nE:

PROBABILIDADE DE P,nP DADO nE:. 


\section{INFORMAÇÃO E INCERTEZA NOS MODELOS DE INFERÊNCIA SOBRE A OCUPAÇÃO COSTEIRA NO BRASIL}

Para o litoral brasileiro inúmeros foram os autores que, entre as décadas de 50 e 80 , focaram seus estudos sobre as diferenças e semelhanças encontradas na cultura material dos sambaquis, procurando o entendimento de possíveis agrupamentos regionais e da reconstituição dos movimentos migratórios ocorridos ao longo da costa (TENÓRIO, 2004:169). Cabe citar que no final deste período, conforme Lima (1999-2000) inicia-se os trabalhos mais profundamente atrelados a visões adapatacionistas, que correlacionavam a cultura sambaquieira com a evolução do ambiente. Neste sentido o próprio deslocamento dessas populações estaria profundamente influenciado por condicionantes fisiográficos, biogeográficos e climatológicos. Autores como COUTO (1968) e MENDES (1970) já esmiuçavam o fato de determinados compartimentos por exemplo, atuarem como incentivo às migrações populacionais e outros, que deveriam constituir como barreiras quase intransponíveis.

No entanto, apesar da busca pelo estabelecimento de unidades culturais e sua dispersão a questão da origem do povoamento costeiro raramente foi debatida. Certamente um dos pontos para isso referia-se as próprias limitações de acesso aos sítios mais antigos, pois como verificado em Serrano (1963), já havia a noção de que sítios disposto em faixas entre 6.000 e 10.000 , se preservados, estariam dispostos em sedimentos abaixo do nível do mar.

Apenas Annette Laming Emperaire vinha se preocupando com o tema, já que almejava testar a proposição de Paul Rivet "sobre a existência de uma rota alternativa por mar usada por grupos que, há muito tempo, já estariam adaptados à vida marinha", o que sugere a perspectiva de uma origem única, vinda de fora (TENÓRIO, op cit.:170).

Neste mesmo período A. BECK verificou a inexistência de trabalhos voltados a compreensão dos processos de povoamento do Litoral e do relacionamento entre grupos litorâneos e grupos do planalto à época da construção dos sambaquis, indicando a necessidade do esclarecimento de aspectos obscuros existentes,

O relacionamento existente entre grupos litorâneos e os grupos do planalto, no período em que durou a construção dos sambaquis. Até o momento não existem trabalhos feitos em sentido comparativo de forma a podermos entender como se processou o povoamento do Litoral. De onde teriam vindo os grupos litorâneos e para onde teriam ido. Quais as rotas de migração utilizadas. O esclarecimento dessas perguntas permitiria entender outros problemas que se colocam na investigação dos sambaquis (BECK, 2007:60). 
Posterioremente, outros autores discutem o problema da identidade dos grupos sambaquianos procurando, através do estudo da distribuição e variabilidade da cultura material, bem como, da diversidade de sítios e acampamentos litorâneos, evidências de diferenciação cultural (DIAS, 1969, 1992; PROUS, 1992; MENDONÇA DE SOUZA, 1981; entre outros). Assim, o questionamento das mudanças adaptativas verificadas nos sítios substitui o foco da delimitação de unidades ou sistemas sócio-culturais (TENÓRIO, op cit, p. 171). Também neste escopo se enquadram propostas de origens variadas para alguns grupos costeiros, como o caso dos sítios da Tradição Itaipu, que poderiam representar populações não ligadas necessariamente a uma adaptação de sambaquianos, embora apresentem vínculos culturais com tais sociedades. Conforme DIAS JR e CARVALHO (1990:160), esses sítios estariam relacionados, a "caçadores, coletores e pescadores diversificados que desenvolveram uma sociedade complexa, paralela aos coletores especializados".

No escopo das proposições acima, LIMA (1991) também compartilha a visão da necessidade de estudo dos sambaquis a partir de uma ótica de diversidade de sistemas sócio-culturais, regidos por particularidades internas próprias, mas cuja origem atribui ao interior. Assim, a autora propõe um modelo hipotético de povoamento da costa brasileira, baseado em modelos de pressão populacional (Osborn) e aproveitamento oportunista (Perlman) indicando ainda o papel da hipotética "barreira" montanhosa da Serra do Mar no processo de fixação desses grupos à costa:

\footnotetext{
"Grupos provenientes do interior teriam alcançado o litoral empurrados por stress populacional em algum ponto do planalto e alcançaram à costa: ao encontrarem ambientes extremamente favoráveis ao seu estabelecimento, teriam se especializado na explotação dos abundantes recursos disponíveis em determinados ecossistemas não só por ação oportunista, mas ainda pela dificuldade de transpor a barreira montanhosa da Serra do Mar" (LIMA, 1991:33)
}

Para TENÓRIO (op cit:172) este modelo traz algumas implicações e problemas, derivados da aparente "falta" de elementos culturais interioranos no litoral: a necessidade de uma rápida mudança de costumes dos grupos interioranos ao meio litorâneo, criando e reproduzindo um arsenal tecnológico totalmente adaptado à exploração de recursos costeiros, ou então, talvez a possibilidade de terem sido "absorvidos culturalmente" por populações pré-existentes e já bem adaptadas ao meio.

No entanto, em publicação mais recente LIMA (1999-2000) também parece concordar que tais movimentos como no caso de grupos ligados aos sambaquis fluviais do Ribeira, teriam ocorrido, sobretudo no sentido litoral-interior, 
Os sambaquis fluviais encontrados ao longo dos cursos desses rios - onde foram recuperados restos de animais marinhos e vestígios culturais tipicamente litorâneos parecem corresponder mais a grupos bem estabelecidos em ambientes costeiros se interiorizando que a caçadores coletores do interior explorando recursos fluviais, a caminho do mar (LIMA, 1999-2000:279)

Esta última proposição está ligada à perspectiva da existência de uma "cultura sambaquiana" de longa data, porém não alheia a um processo de miscigenação contínua, mas que favoreceria a manutenção dessa "cultura" litorânea ou marítma. Na visão de uma unidade sócio-cultural das ocupações sambaquianas do litoral brasileiro, se enquadra o modelo de GASPAR (1991), que se baseia na associação constante de elementos como cultura material, alimentação, padrões de assentamento e enterramento, etc. A autora liga tais sociedades a uma cosmologia própria, com elementos estruturais capazes de manter a coesão do grupo frente a uma ameaça constante da introdução de elementos novos. Esta perspectiva de relativa baixa diversidade cultural para os sambaquis é apoiada também pela aparente ausência de evidências do processo adaptativo interior-litoral entre os sítios estudados.

"Somando-se os pontos convergentes dos modelos construídos por Dias, Andrade Lima e Gaspar ao que foi apresentado, propomos um modelo interpretativo para explicar o povoamento do litoral brasileiro, no qual se parte do princípio de que teria existido uma "cultura sambaquiana" muito antiga formada por grupos marítimos, caracterizados por possuírem um profundo conhecimento de técnicas necessárias à exploração do meio aquático marinho. Esta suposição está apoiada nas similaridades observadas na cultura material, no padrão de assentamento, no fato observado por Gaspar (1991) sobre a constância do hábito de enterrar os mortos em locais que se destacam na paisagem e na ausência de sítios de transição que reunissem elementos do interior e do litoral. (Tenório, 2004:176) [grifo nosso]

Conforme este modelo, os novos costumes trazidos por grupos interioranos não alteraram a "supremacia" desta "cultura sambaquiana" até a chegada dos ceramistas, já que detinham um conhecimento tecnológico bem adaptado e "uma cosmologia bem estruturada constantemente reforçada em rituais que envolviam concentração de pessoas" ${ }^{27}$

${ }^{27}$ Ibidem. 
Esta perspectiva explanatória decorre de raciocínios como o de Yesner $\left(1986^{28}\right.$ apud Tenório, 1995: 46) segundo o qual as áreas litorâneas não só são extremamente ricas em recursos protéicos, mas oferecem alimentos capazes de influenciar a mobilidade e a densidade populacional de grupos humanos, já que a coleta acrescida de produtos marinhos garantiria um alto grau de previsibilidade alimentar. Conforme o autor, os locais escolhidos para assentamento tendem a ser próximos a correntes ascendentes ou estuários, devido a sua elevada produtividade. A presença de moluscos garantiria ganhos protéicos concentrados, de fácil coleta por diferentes segmentos humanos e baixo gasto energético. Por sua vez tanto os moluscos quanto mamíferos marinhos suportariam melhor as explorações intensas, devido a sua capacidade de reabilitação. Assim, considera que grupos costeiros tendem a ocupar áreas capazes de proporcionar nichos ecológicos variados, adotando locais estrategicamente colocados (acampamentos centrais) onde seria possível uma exploração produtiva sem grande mobilidade. Ou seja, estes locais de zonas ecológicas próximas, com maior concentração de recursos tenderiam a ser mais permanentes que outros, podendo incentivar um processo de sedentarização. Esta perspectiva é corroborada por muitos estudos que parecem indicar que tais sítios ocorrem em concentrações, "ocupando áreas centrais a diversos micro-ambientes, cuja exploração simultânea pode suprir as necessidades alimentares dos grupos, sem que haja a necessidade de uma maior movimentação" (GASPAR, 1991).

Um exemplo desses estudos refere-se proposição de DE MASI (2002), que procura demonstrar que em lugares de alta produtividade primária, como é o caso da llha de Santa Catarina, a mobilidade de grupos caçadores-coletores pré-históricos na costa é baixa. Sua análise baseia-se principalmente em avaliações sobre o padrão de assentamento e em medidas de sazonalidade a partir de isótopos estáveis. Estes resultados contradizem o modelo geral proposto por BINFORD (1980), que indicaria uma alta mobilidade de caçadores em áreas tropicais, mobilidade esta que varia inversamente a latitude, temperatura efetiva, duração da estação de crescimento das plantas e distribuição espaçotemporal dos recursos. Segundo MASI (op cit) as populações pré-históricas na Lagoa Conceição (Florianópolis), embora se adaptando a um ambiente variável, teriam subsistido inteiramente na costa, se alimentando principalmente de recursos marinhos, com predomínio do peixe. Tal contexto muda com a chegada de grupos horticultores por volta de 910 A.P. A análise do colágeno também indicou que, de 1735 A.P. até 1210 A.P.,

\footnotetext{
${ }^{28}$ Yesner, David R. Live in the garden of éden: causes and consquences of the adoption of marine diets by human society. In - Food and evolution. New York, 1986
} 
caçadores-coletores das terras altas possuíam uma dieta baseada em recursos terrestres, com cultivo de milho a partir de 1182 A.P., e sem uso de recursos litorâneos.

Por sua vez Tenório baseia-se na posição de autores que confirmam etnograficamente a relação da estabilidade dos recursos litorâneos à tendência ao sedentarismo e ao aumento populacional. Propõe que "para a manutenção desses locais privilegiados seria fundamental um assentamento permanente, o que evitaria que fossem ocupados simultaneamente por outros grupos. Esta necessidade de fixação inviabilizaria uma movimentação constante pela costa, descartando a hipótese de uma ocupação sazonal costeira" (TENÓRIO, 1995 p. 47). Por sua vez, com maior índice demográfico do que o aceito para grupos de alta mobilidade, existiriam elementos para sugerir a hipótese da existência de disputas por esses territórios.

\footnotetext{
"Observando a costa brasileira, podemos verificar que apesar de sua grande extensão, são poucos os locais que apresentam essa junção de vários nichos ecológicos e, ao mesmo tempo, podemos constatar que são exatamente nesses pontos onde estão localizadas as concentrações de sítios arqueológicos. A disputa por esses locais (intersecções ambientais) implicaria na existência de pontos estratégicos de assentamentos que poderiam funcionar como marcas territoriais e diferenciações intergrupais." (TENÓRIO, 1995, p. 47)
}

No entanto, posteriormente TENÓRIO (2004:172) não aposta na mesma perspectiva de "disputa" dos sambaquianos com grupos interioranos, já que a despeito de evidência de entrada de grupos caçadores coletores no litoral (NEVES, 1988), predominaria "a grande similaridade nos elementos mais expressivos em termos quantitativos, fato também constatado por Gaspar (1991), parece indicar a existência de uma cultura sambaquiana agregadora de populações ainda não adaptadas ao litoral." Ainda, para a autora (op cit, p.172), as proposições surgidas sobre a possível existência de rotas migratórias interiorlitoral advêm do fato da ocorrência de grandes concentrações de sítios costeiros, situados próximos aos vales de grandes rios que cortam as serras (tais como Cananéia, Iguape, Baía de Paranaguá, Baixada Santista, etc).

Assim, alguns autores consideram a existência de eixos de comunicação por vias fluviais (ex. NEVES, 1988; LIMA, 1999-2000) e têm indicado como trechos favoráveis as áreas dos vales dos rios Ribeira de Iguape (SP), Itajaí (SC) e Jacuí (RS) e norte do Rio de Janeiro (TENÓRIO, 2004:172). A suposição desses eixos ou corredores também está apoiada em alguns aspectos da cultura material identificada nos sambaquis; da presença de sítios típicos do interior em diversos pontos da costa e; de elementos diagnósticos (zoólitos e pontas de projétil líticas, por exemplo) que evidenciariam, ao menos, relações de trocas existentes entre o litoral e áreas interioranas. 
Uma análise inicial dos dados disponíveis sobre a cultura material encontrada no litoral brasileiro sugere a existência de pelo menos três rotas de entrada. Pelo norte, através do norte do estado do Rio de Janeiro; outra por São Paulo e, talvez, mais de uma pelo sul, por caminhos onde também são encontrados os Cerritos, percorridos por populações associadas aos zoólitos, que também poderiam ter vindo do Uruguai. No sul, parece ter ocorrido um fluxo maior de pessoas relacionadas a diferentes tradições culturais, o que se percebe na diversidade da indústria lítica encontrada em Santa Catarina. (TENÓRIO, 2004:172)

Se para os modelos de origem interiorana de sambaquianos o apontamento desses "caminhos" é apenas esboçado; para os modelos que consideram "cultura sambaquiana antiga", as rotas se restringem muitas vezes, as possíveis movimentações internas entre sambaquis ao longo da costa, sendo a questão das origens pouco tratada, possivelmente devido à exigüidade e problemas de acessibilidade aos sítios do período mais antigo. Para autores como SCHMITZ $(1981,1984)$ e PROUS (1992), a Serra do Mar (Figura 6) também teria papel determinante na circulação de grupos litorâneos, favorecendo movimentos perpendiculares à costa

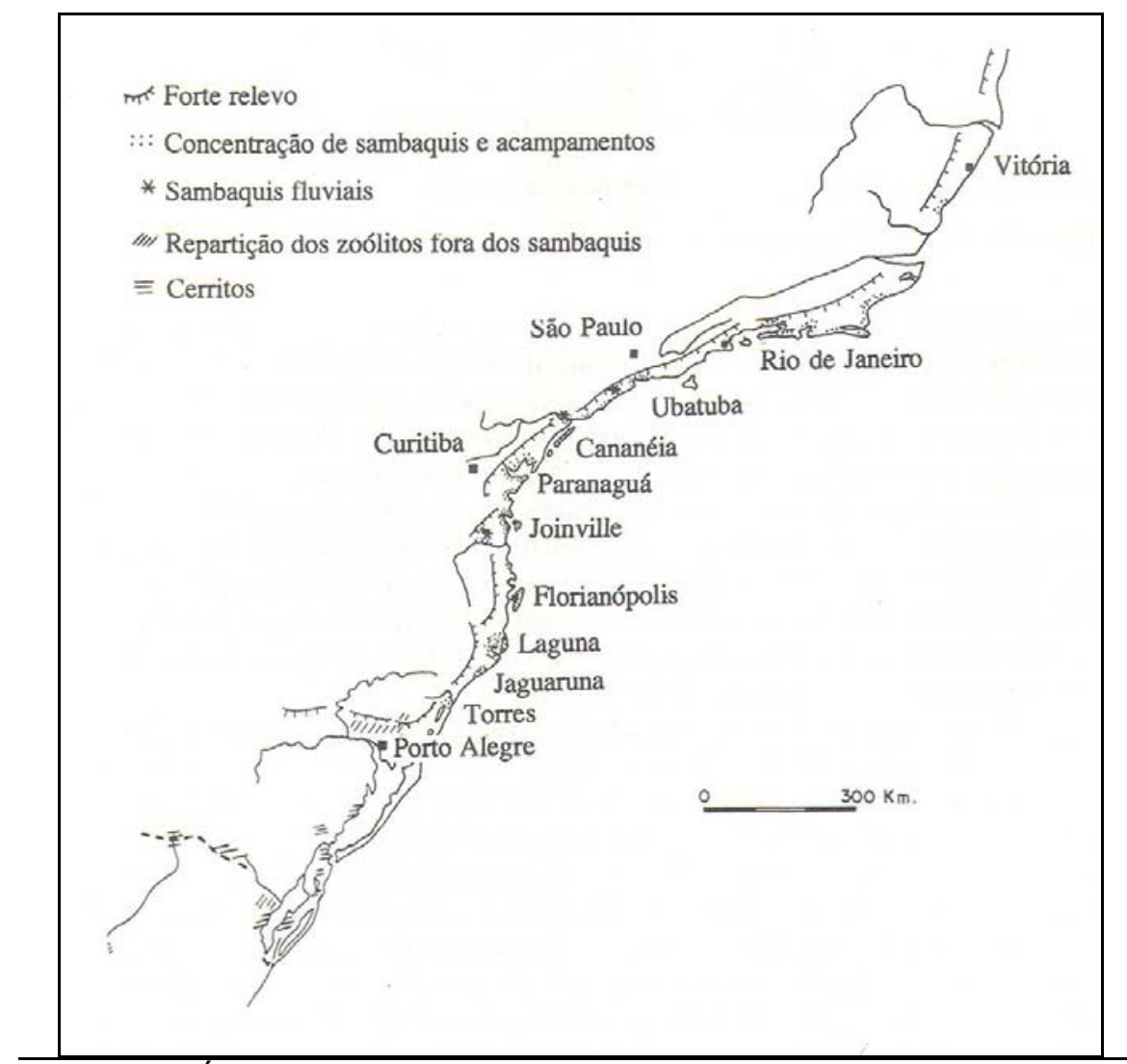

Figura 6: Área de ocorrência de sítios costeiros incluindo as barreiras representadas pelas serras e, os vales ou áreas interioranas onde foram identicados zoólitos fora dos sambaquis (fonte: PROUS, 1992)

Deste modo, apesar do debate e das diferenças de visão quanto à origem e o grau de interrelação-interdependência interior-litoral, o tema das rotas migratórias não apresenta 
ainda bases exploratórias seguras, o que gera inferências e interpretações de pouca consistência

Conforme A. Dias (2003), os dados arqueológicos disponíveis na costa do RGS e que atestam à exploração de recursos litorâneos por grupos caçadores coletores da Tradição Umbu, sugerem que estas adaptações costeiras estariam relacionadas à estabilização progressiva e recente da linha de costa do litoral sul brasileiro. No entanto a autora ressalta que,

"esta possibilidade não deve ser descartada para períodos mais recuados, podendo os sítios derivados destas ocupações costeiras antigas terem sido destruídos pelo vários episódios de transgressão-regressão marinha que caracterizam o Holoceno como um todo" (2003:106)

A maior parte dos autores citados concorda com a possibilidade de destruição ou soterramento de sítios antigos por efeito da elevação do nível dos oceanos, fazendo com que os registros dispostos sobre antigas linhas de costa (rebaixadas em mais de 100 metros, devido à formação e acúmulo de geleiras sobre os continentes no último período glacial), fossem atingidos pela força dos agentes de remodelação costeira.

Em termos globais, e embora haja o reconhecimento do elevado potencial arqueológico existente nas plataformas costeiras do Globo, como já aventado desde Charles Lyell (1872) este enfoque tem sido sistematicamente ignorado por arqueólogos, apesar do crescimento exponencial da pesquisas subaquáticas envolvendo localização, identificação e escavarão de embarcações naufragadas. Para sítios pré-históricos entretanto, salvo raras exceções (COLES, 1998; FLEMMING, 1998), o potencial de sua exploração em ambientes submersos e a importância para os modelos migratórios permanece em grande parte, em uma linhas especulativas. Estudos mais recentes têm retomado a questão do papel dos ambientes costeiros no entendimento e formulação de modelos sobre a ocupação das Américas, notadamente em termos da dispersão de seres humanos pelas zonas costeiras (Westley \& Dix, 2006). Esta temática inevitavelmente traz como implicação a questão não apenas da potencialidade dessas áreas para sítios de idades recuadas (como Pleistocênica ou do Holoceno inferior), mas também a problemática da acessibilidade a esses registros e da limitação de evidências que tornam a inferência sobre o processo de colonização uma tarefa complexa. 


\section{CONTROLES GEOARQUEOLÓGICOS: UMA PROPOSTA PARA O REGISTRO ARQUEOLÓGICO REGIONAL}

Como visto no item 2.2, a perspectiva de análise das fontes de informação e incerteza nos procedimentos arqueológicos teve como proposição à elaboração de um esquema hipotético que pudesse integrar os diferentes tipos de informação e seus processos de transmissão, notadamente nas etapas seqüenciais de análise-sintese envolvidas na geração de evidências e inferências (Figura 4). Por outro lado, esse esquema em conjunto com o conceito de Não-Informação ( $\mathrm{N}$-info) pretende se constituir, nesta proposta, em um instrumento voltado á representação da incerteza e ao controle das perdas e ganhos informacionais relacionados à passagem dos variados níveis de informação. Certamente, devido ao amplo escopo de variabilidades, complexidades e incertezas envolvidas numa compreensão mais aprofundada de cada um dos domínios teóricos da Arqueologia, necessitamos demarcar um campo de observação mais restrito onde existam condições apropriadas para a aplicação das propostas até aqui apenas delineadas.

Para isso, considera-se como já dito anteriormente, que as proposições da Geoarqueologia podem constituir-se um campo propício à investigação do problema da $\mathrm{N}$-info e das possibilidades de seu tratamento. Esta afirmação baseia-se em três suposições: i) de que a geoarqueologia, ao tratar de forma enfática sobre o contexto natural onde se inserem sítios, enfoca a parcela "não cultural" dos mesmos, o que por si só já é uma espécie de "contraponto informativo" necessário à compreensão do próprio fenômeno cultural; ii) a geoarqueologia, por sua capacidade de se integrar a diferentes etapas de pesquisa e participação ativa nos processo inferenciais e interpretativos, pode constituir-se em campo para o desenvolvimento de conceitos e metodologias capazes de unir teorias de recuperação e teorias de formação do registro; iii) as relações entre evidências e inferências no contexto natural, embora também contenham problemas de incerteza (FRODEMAN, 1995; SOARES, 2000), apresentam maior previsibilidade e controle, podendo ser tratadas com base em relações sistêmicas ${ }^{29}$.

\footnotetext{
${ }^{29}$ Neste sentido, remete-se a teoria pragmática de van Fraassen ao considerar explicitamente que a "teoria de sistemas" seja capaz de dar boas explicações em determinados contextos, mas pode não permiti-las em outros (como por exemplo, nos contextos culturais e sociais). Segundo COLANGELO, (1990 p.27): “ A perspectiva sistêmica proposta por Van Bertalanfly (op. cit) para as ciências físicas e
} 
Outro aspecto importante a ser definido ou delimitado refere-se a relação de enfoque e a escala de relação que deverão ser adotadas como domínio preliminar neste trabalho. A primeira relação prioriza a transformação do contexto arqueológico e a dinâmica do contexto físico de entorno e, a segunda enquadra-o nas mudanças associadas à escalas analíticas e interpretativas do Registro Arqueológico Regonal (RAR). A referência dialética dessas relações estaria, em primeira instância, na contraposição entre sítio e meio (natural e análitico) cuja síntese pode ser equiparada à noção de evento geo-arqueológico. Esta perspectiva permitirá desenvolver o conhecimento sobre as relações de movimento e transformação inerentes aos fenômenos e sistemas dinâmicos, delimitado por um domínio investigativo, no qual o registro arqueológico pode ser entendido como um evento ou conjunto de eventos a eles integrado ${ }^{30}$.

Por sua vez, ao considerarmos a paisagem como o resultado de processos e produtos físicos, químicos e bióticos em contínua mudança, necessitamos de mecanismos de observação, recuperação, seleção e tratamento de informações que considerem formação

biológicas estabelece que: um objeto de estudo pode ser visto como "... um todo composto por elementos que se interrelacionam segundo uma certa organização e operação..." Nesse sentido, toda investigação de caráter sistêmico supõe a procura da estrutura organizacional e do complexo operacional de seu objeto de estudo. A estrutura da organização é dada por um certo número de relações e correlações entre os diversos elementos do sistema, ao passo que, a operação subentende uma dinâmica interna entre os mesmos."

${ }^{30}$ Busca-se nesse sentido uma aproximação com as teorias de probabilidade definidas no cap. 2. Em teoria das probabilidades, um evento equivale a um conjunto de resultados (um subconjunto do espaço amostral) ao qual é associado um valor de probabilidade. Quando o espaço amostral é finito (domínio de investigação- $\mathrm{Di}$ ), qualquer subconjunto desse espaço é considerado um evento nele contido (denotação $A \subseteq B$ ). Quanto o espaço amostral é infinito, pode-se definir um espaço de probabilidade, sendo muitas vezes necessário excluir certos subconjuntos do espaço amostral da associação de eventos (definindo numericamente, por exemplo, por limites superiores e inferiores).

Os eventos também são equivalentes a conjuntos (notação entre chavetas \{ \}) e podem ser representados graficamente por diagramas de Venn. Nesses diagramas as probabilidades e condições dos eventos pode ser identificada pela razão entre áreas de eventos e do espaço de probabilidade.

Um evento em sentido mais amplo, pode ser visto como qualquer subconjunto do espaço amostral, incluindo qualquer elemento singular ou o conjunto de todos os elementos (variáveis), o próprio conjunto vazio (probabilidade 0 ) e o espaço amostral inteiro (probabilidade 1). Finalmente, outros eventos são potenciais pois decorrem das possíveis relações estabelecidas entre os múltiplos elementos (variáveis) e sua probabilidade condicional. 
do registro arqueológico sobre um meio dinâmico. São inúmeros os estudos que demonstram esta necessidade, remetendo a preeminência de uma acurada interpretação dos padrões observados na atualidade, regularidades estas que podem refletir tanto a distribuição de atividades humanas, quanto tendências do meio.

Conforme aponta GLADFELTER $(1977 ;$ 1981) embora a abordagem geoarqueológica esteja preocupada inicialmente com o contexto físico no qual os restos arqueológicos são achados, sua atuação deve estar envolvida em todos os níveis de investigação arqueológica, o que inclui perspectivas interpretativas e explanatórias sobre as questões culturais, históricas e sociais. Neste sentido, autores como ARAÚJO (1999, p.43) defendem que a geoarqueologia não deve ser vista como uma sub-disciplina pois, em essência, representaria uma "arqueologia bem feita e amadurecida do ponto de vista teórico e de métodos". Esta acepção, entretanto, não prescinde da necessidade de formulação de uma base conceitual própria, alicerçada por especificidades teórico-metodológicas, e que almejaria um papel ativo nos processos de inferência cultural (BUTZER, 1977:126).

O desenvolvimento da abordagem geoarqueológica e as implicações das chamadas "ciências da terra", em teoria e métodos arqueológicos foram abordados por vários autores, dentre os quais RAPP (1975), HASSAN (1978, 1979); GLADFELTER, (1977, 1981), BUTZER, (1977), WATERS (1992) e RAPP \& HILL (1998).

Neste sentido, ARAÚJO (1999) também destaca o papel dos estudos geoarqueológicos na própria estrutura teórica da arqueologia. A partir dos modelos formulados por CLARKE (1973) e SULLIVAN (1978), o autor propôs uma organização da divisão de cinco conjuntos teóricos interconectados: Teoria Explanatória; Teoria Formativa; Teoria Formal ou Sistemática; Teoria de Recuperação e Teoria Inferencial. Na sua concepção, a geoarqueologia estaria associada à Teoria Formativa, relativa aos processos de formação do registro, e também, faria parte essencial da Teoria de Recuperação, "que abrange as relações entre o observado e o existente no registro arqueológico, permitindo que o arqueólogo tome decisões compatíveis com as questões a serem respondidas, antes e durante a manipulação de vestígios" (ARAÚJO, op cit. p.41). Por fim, também estaria ligada à Teoria Inferencial, que compreenderia a junção de todos os corpos teóricos e aos processos envolvidos na síntese das diversas linhas de evidência, com o objetivo de produzir inferências sobre o registro arqueológico (ARAÚJO, op cit, p. 43).

A possível inter-relação dos aspectos de formação do registro arqueológico (Teoria Formativa), suas conseqüências sobre os métodos de recuperação e produção de evidências (Teoria de Recuperação) e a produção de inferências (Teoria Inferencial) ou interpretações (Teria Explanatória) tem sido esboçada por diferentes autores (ASCHER, 1968; COWGILL, 1970; COLLINS, 1975; SCHIFFER, 1972, 1976; entre outros). Por sua vez, SCHIFFER $(1983,1987)$ procura sintetizar tais relações sob enfoque dos chamados 
processos de formação de registro arqueológico que, segundo ele, necessitam ser compreendidos em termos de sua natureza e operação, dos efeitos ou influências sobre as evidências do passado e, dos depósitos específicos a ele relacionados (SCHIFFER, 1983, p. 676) Adota então, uma perspectiva de transformação (transformation view) do registro arqueológico desde seu contexto sistêmico (systemic context) até seu contexto arqueológico (archaeological context), e cujos vieses poderiam ser tratados através de leis ou princípios de regularidades gerais conhecidas por c-transforms (transformações culturais) e $n$ transforms (transformações não culturais ou naturais). Conforme este "modelo de transformação", os processos de formação introduzem variabilidade no registro arqueológico: "patterns are destroyed or modified, new patterns are created; materials are destroyed or modified, new materials are added" ${ }^{31}$, e assim, "as a prerequisite for making virtually archaeological inferences, the archaeologist must identify the processes that gave rise to the specific deposits that are to supply relevant evidence"32.

Deste modo, embora reconheça as grandes limitações do registro na produção de inferências arqueológicas, Schiffer denota duas "vantagens" deste modelo sobre a visão entrópica tradicional (ex. ASCHER, 1968, que considera a passagem do tempo, como fator principal na redução sucessiva da quantidade e qualidade das evidências): a percepção de que processos de formação não apenas produzem perdas, mas também introduzem certos padrões (e portanto, "ganhos") e; que ao exibir padrões que lhe são inerentes, the distortions can be rectified by using appropriate analytic and inferential tools built upon our knowledge of the laws governing these process (e.g., Schiffer 1976:12) ${ }^{33 " .}$

O modelo de Schiffer parece representar aquele que mais se aproxima de uma perspectiva conceitual capaz de ligar as informações processadas nos diferentes campos teóricos da Arqueologia. No entanto, seu enfoque metodológico recai quase que exclusivamente sobre a variabilidade dos "processos de formação" como fonte de incertezas, distorções e viés. Mesmo neste sentido, pretende tratá-las a partir de suas regularidades ou padrões, que seriam conhecidas por meio dos princípios e "leis" que governariam esses processos. Como vimos no Capítulo 2, a ligação entre teorias gerais e fatos pode ser ambígua e circular, quando geradas e tratadas por métodos puramente dedutivos e indutivos ${ }^{34}$, visto que poderia ordenar e direcionar as observações e seleções, suprimindo exatamente o caráter essencialmente impreciso e complexo dos fenômenos naturais e culturais. Por sua vez, existem outras fontes de incerteza e tendências que interceptam e extrapolam os "processos

\footnotetext{
${ }^{31}$ SCHIFFER, op cit, p. 678.

32 Ibidem

33 Schiffer, op cit, p.677.

34 Adotando-se neste caso, a possibilidade de que as atividades de geração de evidências empíricas podem refletir uma total dependência em relação às teorias que nelas são empregadas.
} 
de formação" e que poderiam ser mais bem compreendidas em termo da análise dos "processos de informação" subjacentes. É o caso por exemplo, dos processos de recuperação e análise, que como enfatizado por SULLIVAN (1978) e GALLAY (1986), entre outros que, também introduzem variabilidade no registro arqueológico e, se não tratados, produzirão viés interpretativo sobre as próprias inferências feitas sobre os processos de formação.

No trabalho de SCHIFFER (1987), a falta de uma análise mais detalhada sobre a ligação entre teoria de formação e teoria de recuperação, pode ser percebido na descrição dos "Processos de Formação Ambiental" (Environmental Formation Processes) para a escala do Registro Arqueológico Regional (RAR) ${ }^{35}$. Embora o autor considere que existem inúmeras conseqüências da ação dos processos ambientais regionais sobre o comportamento cultural e sobre sítios arqueológicos, acabar por destacar os efeitos da visibilidade e acessibilidade em artefatos e sítios. Assim, por exemplo, sedimentos e vegetação são fatores que alterariam "the extent to which an observer can detect the presence of archaeological materials at or below a given place" (visibilidade) bem como, as características do terreno, biota, estradas, etc, afetariam o "efort required to reach any particular place" $(\text { acessibilidade) })^{36}$. Complementa ainda que tais fatores,

\begin{abstract}
Along with the obtrusiveness of archaeological materials [e.g. ecofacts] and survey techniques, influence what is found on archaeological survey. Survey data, of course, are the bases for inference of settlement systems and regional and interregional cultural processes. (...) Too often, however, elaborate models of cultural processes gave been built on a base of biased evidence; the discovery of new evidence - the existence of which could have been foreseen if regional processes had been considered - overturns these models and new ones must be built. Reconstructions can be made less vulnerable to 'hidden evidence' by properly designing new regional investigations and by taking into account regional formation processes when using data from previous studies. (SCHIFFER, op cit, p. 236)
\end{abstract}

Deste modo, embora existam inúmeros discernimentos sobre o uso dos termos visibilidade e acessibilidade (BROCHIER, 2004, p.38) ${ }^{37}$ para Schiffer, estes estariam ligados

35 Op.cit., p.235-262

${ }_{36}^{36}$ Op.cit., p.236

37 "Para o caso da visibilidade, por exemplo, muitos autores variam suas concepções entre considerála um atributo dos próprios sítios ou materiais arqueológicos, como é o caso de grandes sambaquis, considerados de "alta visibilidade", ou ainda, de atributos específicos do ambiente ("a baixa visibilidade dos ambientes florestados"). Neste ultimo aspecto, pode-se compreendê-la como uma capacidade do meio em expor vestígios culturais (ex. feições de exposição de solos, processos erosivos); ou então, como uma interferência do ambiente na possibilidade de observação (ex. 
essencialmente à influência das condições ambientais [e antrópicas atuais] na "observação" ou no acesso do "observador" ao RAR, o que remete a aspectos de observação/detecção/registro ${ }^{38}$ e não necessariamente a processos de formação natural do registro arqueológico. Ao mesmo tempo, tais fatores têm sua expressão material própria na paisagem (vegetação, sedimentos, feições erosivas, estradas, etc) e, portanto, são elementos (fenômenos) do contexto físico "não arqueológico". Assim, embora não sejam parâmetros abstratos ou técnicos de recuperação, e não necessariamente estejam compartilhados com determinados contextos arqueológicos, podem ainda ser capazes de produzir tendências e incertezas nas interpretações sobre o RAR.

Ao considerar o enquadramento da presente pesquisa com o estudo do RAR pretende-se demonstrar, sobretudo, a necessidade de compreender as perdas e ganhos informacionais associadas a eventos arqueológicos (relação sítios e meio), sob a ótica não apenas a uma "Teoria de Formação", mas também de sua passagem para outros campos teóricos da Arqueologia, notadamente o da "Teoria da Recuperação" (ARAÚJO, 1999). Por sua vez, o enfoque sobre o contexto físico-natural associado ao RAR, apresenta problemáticas de recuperação próprias (SCHIFFER, 1987, p.339-64 aborda rapidamente a questão), notadamente quando relacionadas com ambientes dinâmicos e cuja evolução geosistêmica introduz variabilidades de informação contidas nesse "registro arqueológico" em "escala regional". Assim, considera-se o "olhar" geoarqueológico como o mais adequado a este tipo de abordagem de recuperação.

Dentre os estudos eminentemente geoarqueológicos voltados à caracterização das perdas e ganhos de informação no Registro Arqueológico Regional, determinando diferenças entre o preservado e o existente, pode-se destacar àqueles relacionados aos efeitos dos processos erosivos em ambientes costeiros e fluviais (WATERS, 1992; BLUM ET AL., 1992; KELLOGG, 1995; WATERS \& KUEHN, 1996; BROOKS ET AL., 1996; RICKLIS \& BLUM, 1997; FAUGHT \& DONOGHUE, 1997; BROWN, 1997; GUCCIONE ET AL., 1998; WATERS

cobertura vegetal, camadas sedimentares). Por fim, pode-se associá-la aos métodos e técnicas de prospecção, que em síntese nada mais são que a escolha do tipo de "observador" que queremos, ou ainda, qual o alcance de "observação" pretendido, condições essas que podem alterar a visibilidade de uma área ou registro" (Brochier, op cit, p.38)..

${ }^{38}$ conforme Fogaça (1995) "a localização de diferentes classes de sítios em uma determinada região: ela depende, dentre vários fatores, daquilo que os arqueólogos anglo-saxões denominam obtrussivenes ( SCHIFFER; SULLIVAN; KLINGER, 1979): uma determinada metodologia de levantamento e prospeç̧ão leva à descoberta de uma determinada classe de sítio. (É necessário entretanto ressaltar que, para os arqueólogos dedicados a estudos de arqueologia regional, a descoberta de sítios à céu-aberto enterrados e o controle de tais amostras permanecem um problema maior [CALDARELLI: seminários realizados no IGPA/UCG durante o Projeto de Pesquisa Arqueológica das UHEs Serra da Mesa e Cana Brava, 1989- 1990]);". 
ET AL., 1999; LEWIS, 2000; entre outros). Por exemplo, WATERS \& KUEHN (1996) enfocam as problemáticas envolvidas na evolução dos processos erosivos em áreas arqueológicas, considerando que em alguns eventos erosionais regionais removem completamente sedimentos antigos e solos que podem conter sítios arqueológicos: "quanto maior o número, duração e intensidade dos eventos erosivos maior a destruição" (WATERS \& KUEHN, op cit, p. 484). Para os autores torna-se necessário determinar a estrutura da seqüência geológica da paisagem, caracterizada através do estudo da magnitude, número, duração, extensão em área e, ajustamento dos períodos de deposição, erosão e estabilização. "Estes fatores controlam como muitas unidades sedimentares, paleosolos, e superfícies erosivas estão presentes, sua distribuição e seqüência, e a quantidade de tempo que representam" (op cit., p. 485, grifo nosso).

No entanto ao considerarmos a inserção de sítios arqueológicos na paisagem, também necessitamos de controles sob sobre os fatores interpretativos e analíticos de investigação, que perpassam a dois tipos de escalas informacionais. A definição do termo escala é adotada aqui como próxima ao conceito de "resolução" (associado ao nível de detalhamento ou precisão da informação) e não necessariamente no sentido de "tamanho" (conceito comparativo entre pequeno/grande, curto/longo). Resolução para SCHUMM (1991) é parte do conceito de espaço (campo tridimensional onde os fenômenos investigados ocorrem, conforme o campo de observação do investigador). O tamanho ou resolução no qual um objeto ou fenômeno é medido ou observado insere-se no espaço como campo tridimensional situacional. Assim é também possível associar escala a informação.

É preciso tem em mente que em geral, conforme STEIN (1993:3) durante uma pesquisa existem pelo menos dois tipos de escala: 1) a escala onde objetos são observados e medidos, durante a aquisição de dados, e 2) as escalas espaciais e temporais utilizadas durante a fase de interpretação. As escalas utilizadas durante a aquisição ou observação de dados (escala analítica), em geral, são escalas ligadas a questão de tamanho (size) e que envolvem o processo descritivo. Para as escalas interpretativas entretanto, a questão é mais complexa, já que existe um vínculo maior com as perguntas e questões a serem respondidas e a escala dos objetos de análise interpretativa (como exemplo: arqueólogos, geógrafos e geólogos podem observar o mesmo afloramento e chegar a diferentes interpretações). Outro aspecto refere-se ao uso do conceito de tempo, muito mais utilizado nas escalas interpretativas. Embora unidades estratigráficas estejam atreladas a escalas tipo "analítica" (agrupamento natural, observável), o tempo envolvido neste tipo de agrupamento é uma construção interpretativa, não observável. Portanto, as escalas de tempo a serem utilizadas em uma determinada pesquisa são construídas durante a fase de interpretação (STEIN, op. cit, p. 4). 
Ainda para a autora, as escalas preferidas para interpretação envolvem o conceito de resolução, em parte porque a arqueologia e as geociências são ciências históricas que envolvem longos períodos de tempo, áreas amplas e muitos sistemas nos quais não existem analogias modernas. Por sua vez

"(...) The nature of historical evidence es that the older the event investigated, the more fragmentary the record. This fragmentation does not prohibit reconstruction of the event. It just forces the resolution at which interpretations are made to shift to a larger scale. The geológical time escale is vivided into smaller increments for the Cenozoic than it is for the Paleozoic, because more of the Earth's Cenozoic record is preserved and accessible. Archaeological culture histories are the same; more detailed for the last millennium, with exponentially less detail for each millennium further in the past .(...) This destruction affects the precision an, therefore, the resolution at which interpretation can be made (Stein, 1993:3-4)

As incertezas em escalas ocorrem quanto a observação/registro de dados ou a interpretação de evidências/inferências são feitas em escalas não compatíveis com o tamanho do objeto ou a resolução de uma evidência. Esta incerteza também ocorre quanto são utilizadas escalas adequadas para a aquisição de dados, mas escalas inadequadas na interpretação..

Do ponto de vista das escalas o interpretativas em estudos de escala regional, a Arqueologia procuraria resolver problemáticas como origem, diversidade biológica e movimentos migratórios, mobilidade dos grupos, demografia, patologia, evidências de disputas, territorialidade, padrões gerais de assentamentos de macrobandos e economia pré-histórica, variabilidade tecnológica, entre outros. Em outro nível de resolução interpretativa, tomando por conta os atributos exclusivos dos sítios (dispersão, concentração ou aleatoriedade) e das variáveis ambientais, os pontos de interesse cultural compreenderiam: 1) articulação espacial, temporal e funcional dos sítios em âmbito regional e local;2) identificação de sistemas de assentamento e sistemas sócio-culturais; 3) inferências ambientais e paleoambientais;

Por fim, em termos dos tipos de resoluções analíticas relativas ao RAR, e para os quais temos mais condições de estabecer controles refere-se aos aspectos de ocorrência de sítios (preservação-destruição / observado - não observado); distribuição (relações espaciais com o meio); cronologias (continuidades e descontinuidades temporais envolvidas nessas relações); contexto relacional (associações e correlações, estruturas e contextos); ordenamentos de seqüência (coexistências e sucessões de eventos); ordenamentos de geometria (ordenamentos espaço-relacionais); de magnitude (número, duração, intensidade, extensão em área, etc.); ou de hierarquia (níveis de organização). 


\subsection{Controles GeoArqueológicos: Conceito e Modelo geral}

Se os contextos estrutural, dinâmico, evolutivo das paisagens naturais e tecnogênicas podem interferir na geração e recuperação de dados ou informações utilizados nas inferências arqueológicas, torna-se imprescindível a concepção de conceitos, métodos e técnicas específicas que permitam avaliar não apenas o potencial das fontes informativas, seus processos de transmissão/seleção, mas também as fontes de incertezas e vieses agregados.

Em contrapartida ao problema da $\mathrm{N}$-info, o tratamento informacional por controles permitiria predições mais confiáveis ao processar as inúmeras fontes de variabilidade de escolhas e identificando aquelas de maior probabilidade de seleção. Assim, por exemplo, compreender os processos-produtos envolvidos na atuação de fatores erosivos, deposicionais e pedogenéticos permite prever determinantes de preservação, transformação, destruição, capeamento e exposição de depósitos arqueológicos nos diferentes compartimentos ambientais abordados. Algumas dessas percepções são bastante utilizadas em levantamentos arqueológicos de meios específicos, como turfeiras ou áreas cársticas, cujos condicionantes geológicos e físico-quimicos de preservação, atuam de forma seletiva previsível sobre determinados vestígios materiais e sua informação contida.

Do mesmo modo, tais condicionamentos também sugerem a existência de outros fatores naturais preditivos capazes de controlar a ocorrência e distribuição de determinados registros arqueológicos em uma escala regional, independentemente dos processos culturais envolvidos em sua formação. Sob esse enfoque, tais fatores aproximam-se do conceito de controles utilizado em geociências, ou seja, aspectos que regeriam (pelo menos em parte) a presença ou ausência de depósitos minerais, o posicionamento de camadas ou feições geológicas de interesse, determinações estruturais ou tectônicas na paisagem, padrões e orientação de drenagens, etc. Os controles geológicos também estão por trás da modelagem e detecção de armadilhas ("trapps") de petróleo e gás em bacias sedimentares profundas.

$\mathrm{Na}$ Arqueologia, o termo controle geralmente remete a idéia de domínio e sistemática na recuperação de dados em matriz sedimentar, como é o caso do uso de controles estratigráficos nas escavações. No entanto, em termos teóricos, GOLD (1990) ao justificar a necessidade básica do uso controles em teoria arqueológica como ferramenta essencialmente científica de análise, aponta que seu conceito é ainda bastante negligenciado pelos arqueólogos:

The relationship of controls to archaeological theory has been strangely neglected, despite the implicit importance of controls whenever archaeological theory is discussed or used. 
This is almost a definitional matter, since one cannot speak of science in any sense without invoking controls at every level of analysis. Most failures in archaeological inference can be traced to inadequate controls, often in the form of assumptions that were overlooked and were, therefore, incontrolled. Clarke is silent on the matter of controls in archaeological analysis, although his discussion presupposes a controlled approach. Schiffer's (1987) treatment of formation processes in the archaeological record can be read as a review of controls that are necessary in archaeological inference, even though he is rarely explicit about this. By distinguishing between the behavioral context, in which materials actively circulate within the cultural system, and the archaeological context, wherein materials pass out of the cultural system and into some kind of natural context of deposition. Schiffer affords archaeologists the opportunity to apply controls effectively when attempting archaeological inferences. Hodder's (1986) views notwithstanding, archaeologists cannot expect to read the past or presume to infer symbolic components of past cultures without first controlling for natural processes that affect the archaeological record upon which these inferences must be based. (GOLD, 1990, p.18)

Por sua vez, a utilização de controles em estudos arqueológicos pode basear-se em conceitos derivados de Ciência da Informação e da Cibernética ${ }^{39}$, considerando que tais campos tratam essencialmente das relações de ganhos e perdas informacionais (entropia positiva e negativa). Também se vinculam a diferentes teorias de incertezas (teoria das evidências, teoria dos conjuntos nebulosos, dos conjuntos de aproximação, lógica difusa, etc) ou ainda, das formas de representação e tratamento das imperfeições ou imprecisões da informação (perfeita, imprecisa, incerta, vaga, probabilistica, possibilista, inconsistente, incompleta, etc.).

Esta aproximação teórica com as ciências da informação compreende, para o caso deste trabalho, o desenvolvimento de abordagens direcionadas à modelagem informacional de sistemas naturais e o controle de informações geoarqueológicas em escala regional. Assim, no presente estudo foi utilizado o conceito de Controles Geoarqueológicos (BROCHIER, 2001) cuja amplitude de enfoque, como visto anteriormente, pretende atender não apenas a perspectiva de estudo dos processos de formação de sítios (site formation processes), mas também, a base informacional (processos de informação) associada à aquisição e manipulação de dados e; seus efeitos sobre as inferências arqueológicas resultantes.

\footnotetext{
${ }^{39}$ A própria palavra Cibernética tem sua origem no grego, significando timoneiro, ou seja, sugere a metáfora sobre as estratégias estabelecidas pelo timoneiro para o deslocamento e governo de embarcações sobre um meio dinâmico. A palavra pode ser entendida como controle da informação em sistemas complexos. Porém, não se importa com a estrutura específica ou organização intrínseca dos sistemas, mas com a extensão com que estão sujeitos a fatores de determinação e controle.
} 
Assim, os Controles Geoarqueológicos (CG) consideram os fatores de origem natural e analíticos incidentes sobre diferentes níveis de informação arqueológica (geração, recuperação, tratamento, inferência e interpretação), como capazes de interferir, influenciar, condicionar ou determinar as características do Registro Arqueológico Regional (RAR). Deste modo os CG podem ser modelados a partir das relações estruturais, dinâmicas e evolutivas da paisagem, permitindo caracterizar ou antever controles sobre aspectos informacionais e contextuais entre sítios e o meio (natural e analítico).

A variabilidade a ser considerada na determinação dos CG abrange amplo espectro de fatores (Figura 7), que por sua vez, são controlados pela duração e intensidades (magnitude) de processos-eventos, pelas variáveis de energia, pelo grau de organização/desorganização dos sistemas e suas relações hierárquicas, fatores geoecológicos, entre outros.

FATORES SUCESSIONAIS INTERVENIENTES

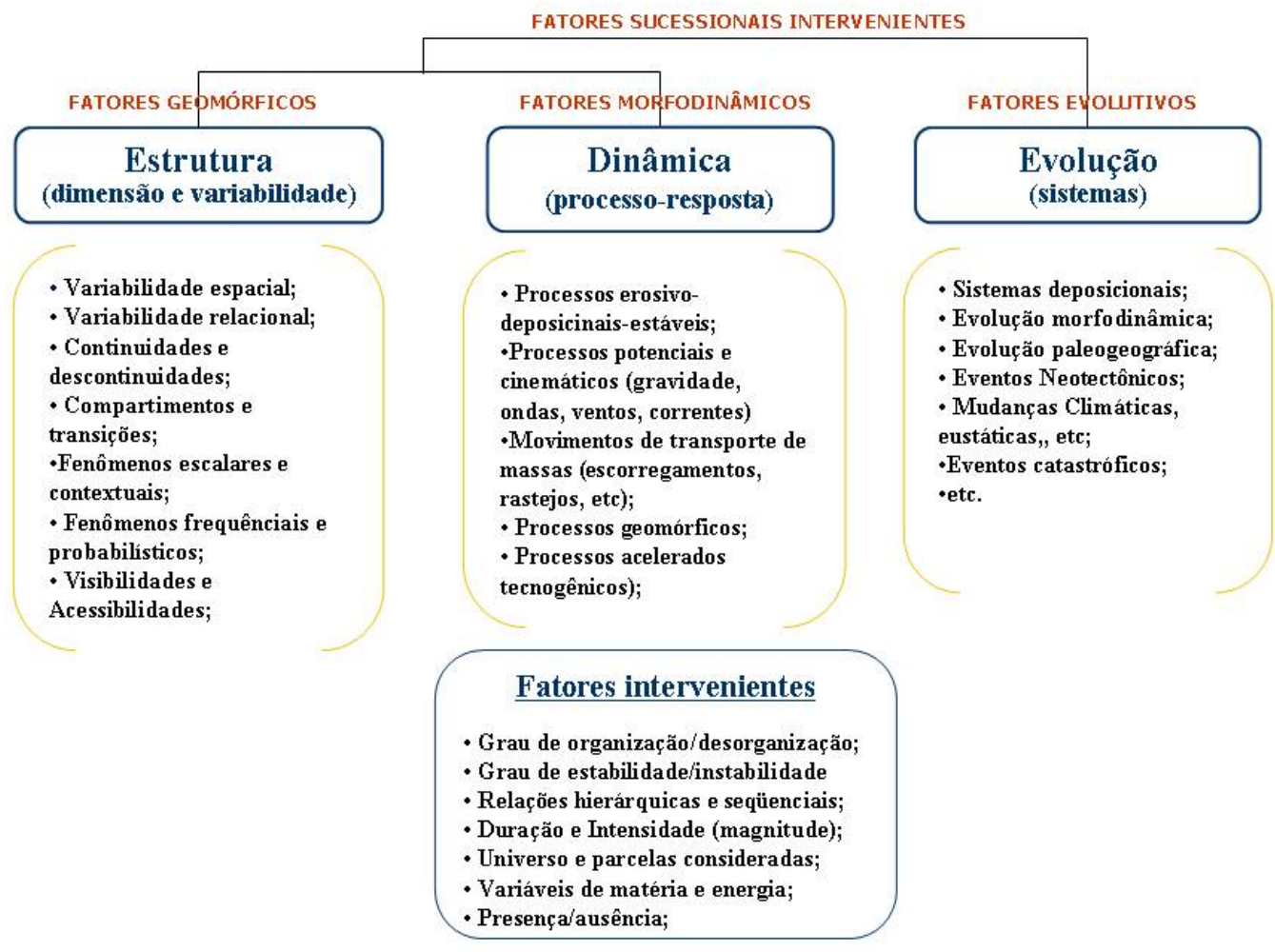

Figura 7: Principais fatores ligados a estrutura, dinâmica e evolução das paisagens geoecológicas envolvidos na determinação de Controles Geoarqueológicos.

Apenas pela enumeração dos diferentes fatores geomórficos, morfodinâmicos e evolutivos acima, já emerge a complexidade da tarefa de determinar controles geoarqueológicos que atendam a todas essas dimensões, processos e sistemas. Como exemplo de uma análise neste sentido, temos nos processos erosivo-deposicionais-estáveis (esquematicamente contido nos fatores morfodinâmicos) algumas relações de formação e informação desses 
fatores morfodinâmicos com o RAR (Figura 8). Nela, os fatores de deposição, estabilização, intemperismo, erosão e transporte determinam não apenas as características físicas ligadas ao registro arqueológico (contexto primário, capeamento, contexto secundário, etc), mas também nas relações informacionais voltadas à determinação das evidências e inferências arqueológicas.

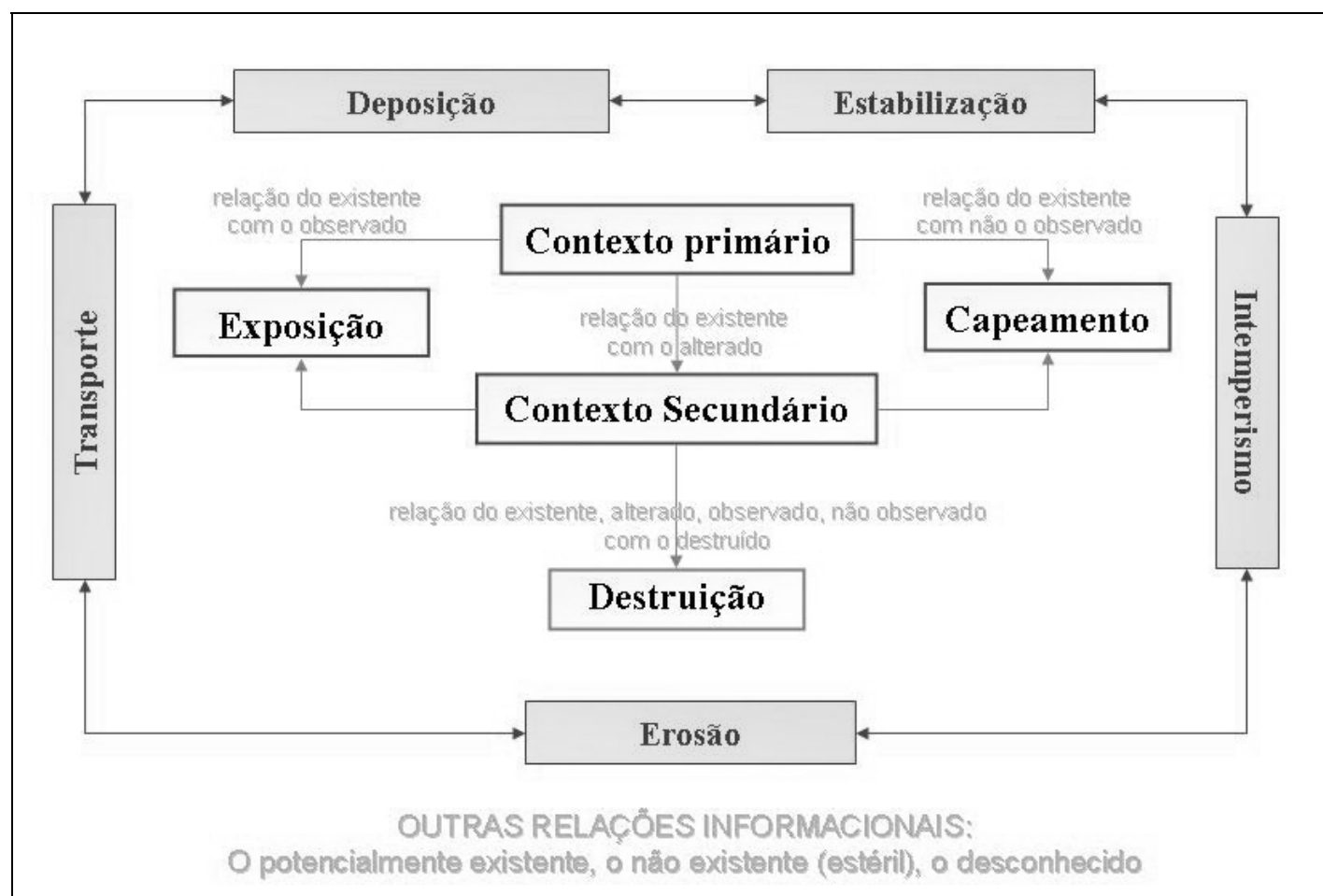

Figura 8: Principais relações informacionais investigadas no estudo dos processos geológicossedimentares ligados à caracterização do registro arqueológico em ambientes dinâmicos.

Ou seja, a idéia de Controles Geoarqueológicos permeia teorias ligadas não apenas a relação dos processos de formação do registro arqueológico (Teoria de Formação ou Transformação) mas também aos processos de recuperação (Teoria de Recuperação). Os primeiros estariam centrados na relação entre "geoderminantes" (erosão, transporte, deposição, etc.) e "arqueodeterminantes" (contexto primário, secundário, destruído); e os segundos, envolveriam os tipos de relações informacionais consideradas (existente com o observado, existente com o alterado, potencialmente existente, etc.). 


\section{CONSIDERAÇÕES SOBRE CONTROLES GEOARQUEOLÓGICOS NAS ÁREAS COSTEIRAS DE GUARATUBA-PR E CARAGUATATUBA-SP}

\section{1 Área da Baía de Guaratuba: controles e corredores no estudo dA ESPACIALIDADE DE SAMBAQUIS}

A área da Baia de Guaratuba apresenta características fisiográficas e compartimentais peculiares que a diferencia das demais áreas da extensa costa sul-sudeste. Neste litoral de "planícies costeiras e estuários" (MUEHE, 1998), a Serra do Mar encontra-se mais interiorizada possibilitando a formação de extensas planícies (de cordões litorâneos) cobertas por restingas e, a presença de baías, como as de Babitonga, Guaratuba e Paranaguá (Figura 9), onde predominam manguezais, planícies de maré, canais e e fundos rasos, etc. Quanto às características da linha de costa, ocorrem algumas diferenças entre o estado de Santa Catarina, de aspecto mais recortado e o do Paraná, o qual apresenta a formação de extensos arcos praiais. Para o estado paranaense, ANGULO e ARAÚJO (1996) propuseram uma tipologia da linha de costa, tendo por base sua dinâmica atual, e que também poderia ser extrapolada para a área norte de Santa Catarina: a) Costa Oceânica com presença de praias arenosas e dinâmica dominada por ondas e correntes de deriva litorânea; b) Costas Estuarinas, com amplas planícies de maré e dinâmica dominada por marés e correntes de maré e; c) Costas com Influência das Desembocaduras, com dinâmica mais complexa envolvendo a interação de ondas, correntes de deriva litorânea e correntes de maré.

As caracterizações acima são importantes, na medida em que representam variáveis de energia que incidem sobre os diferentes compartimentos geomórficos costeiros, determinando a ação de processos dinâmicos ou estabilizadores da paisagem. Para o caso da baía de Guaratuba, por exemplo, os levantamentos e estudos realizados para a presente discussão enfocam a investigação dos processos de formação natural e de transformação pós-deposicional do registro arqueológico em escala regional. Esses estudos voltam-se aos processos geológicos e fatores naturais que controlariam a preservação, remobilização ou destruição de sítios arqueológicos, considerando o papel da estrutura, dinâmica e evolução dos ambientes costeiros. 


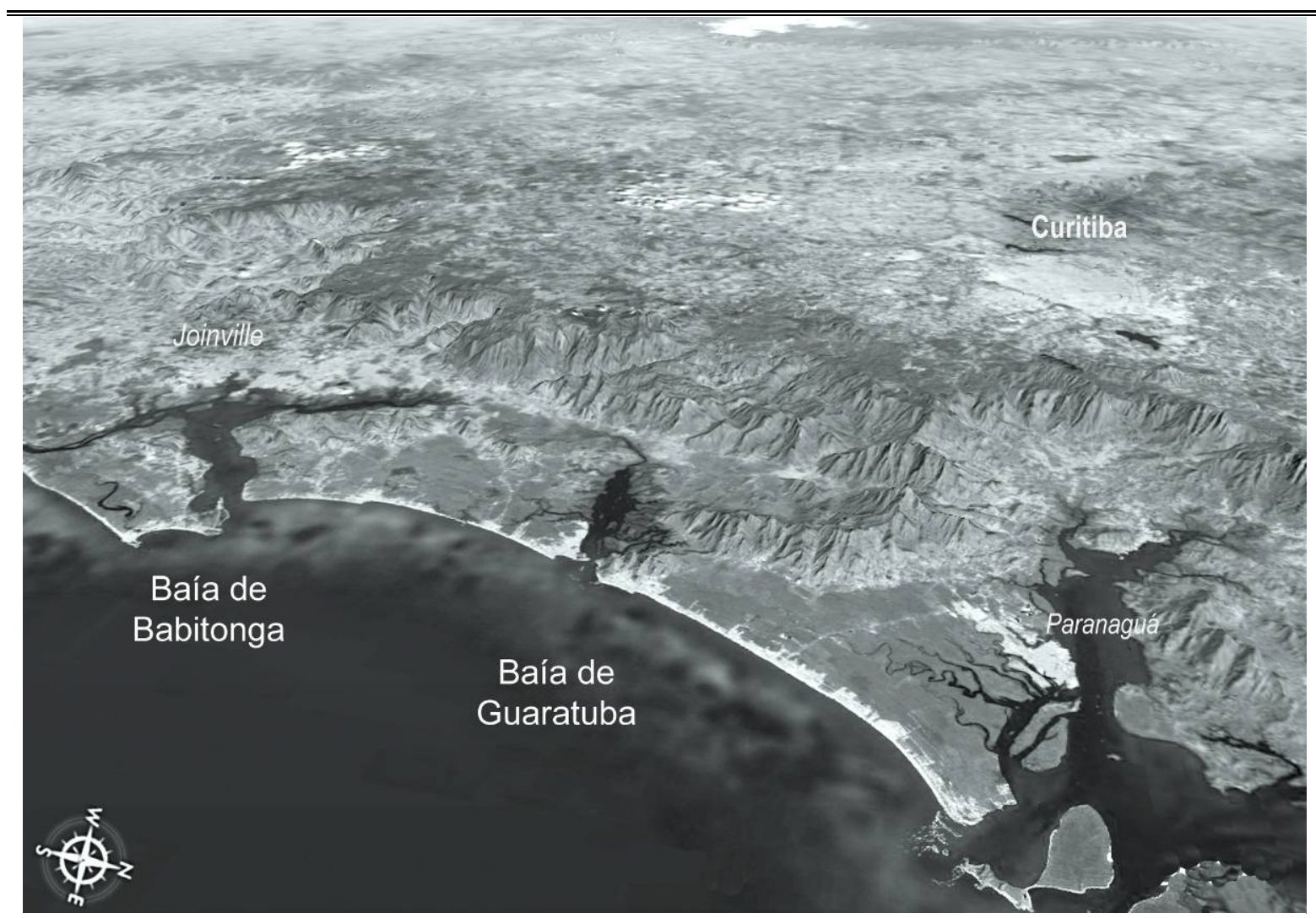

Figura 9:Disposição das baías de Babitonga, Guaratuba e Paranaguá, entre o estado do Paraná e norte de Santa Catarina (fonte: Google, 2005).

Tal proposição remete também à preeminência de uma acurada interpretação dos padrões de sítios observados na atualidade, regularidades estas que podem refletir tanto uma distribuição de atividades humanas quanto possíveis tendências (vieses) geradas por fatores geológicos ou por insuficiências nos métodos de levantamento.

Neste sentido, um dos pontos em discussão compreende a necessidade de rever algumas das percepções amplamente adotadas em estudos arqueológicos geocosteiros, que podem carregar consigo algumas dessas tendências e insuficiências:

1 - Os sambaquis seriam os únicos indicadores pré-históricos úteis em estudos costeiros, notadamente em termos da pesquisa de paleoníveis marinhos e paleolinhas de costa. Esta asserção desconsidera o potencial de informações pertinentes a outros tipos de sítios localizados ao longo da costa brasileira, notadamente, àqueles dispostos em subsuperfície. Assim, sítios com camadas arqueológicas discretas e associados à atividades especificas, podem apresentar melhor resolução espacial e cronológica para problemáticas geocosteiras. Muitos desses registros, por estarem imersos em matriz sedimentar e pedológica, carregam em seu contexto de deposição, ecofatos e geofatos que ampliam sua capacidade informativa. A quase ausência de pesquisas subsuperficiais tem levado arqueólogos a desconsiderar, por exemplo, a existência de sítios líticos (de economias do tipo caçador coletor) em períodos contemporâneos às ocupações sambaquieiras mais 
antigas. No entanto, no litoral do Paraná, os únicos dois sítios líticos com pontas de projétil encontrados em contexto estratigráfico estão em profundidades de difícil detecção em ambientes costeiros. Um dos sítios foi encontrado por Bigarella (Bigarella, Bigarella e Jost, 1975) no sopé do Morro Escalvado, a 1,1 km do sambaqui de Matinhos. Seus vestígios incluem resíduos de lascamento e pontas líticas pedunculadas com aletas e estavam dispostos em um paleosolo exumado a cerca de 1 metro de profundidade, sob sedimentos arenosos. Chmyz et al. (2003) realizaram as primeiras intervenções arqueológicas neste sítio (denominado PR P 41 - Leonel) que o datou em $2750 \pm 250$ A.P (LACIVID-USP). O outro sítio, PR P 31- Ribeirão (Chmyz, 1975), foi encontrado nas proximidades de Paranaguá (Alexandra), está disposto em meio a camadas arenosas, com estratificações paralelas e cruzadas, em plena barreira pleistocênica (conforme mapa geológico de Angulo, 1992). Os vestígios estavam posicionados nas porções medianas da camada 4 até a base da camada 2, entre 130 e $190 \mathrm{~cm}$ de profundidade, juntamente com esparsos fragmentos de carvão (Chmyz et al, 2003). A base deste sítio está sobre uma camada arenosa, bem compacta, de cor marrom tendendo para o preto (piçarra?). Considerando as datas mais antigas obtidas para esses sítios líticos no leste do estado do Paraná (entre 755 e 3750 A.P, citada por Chmyz et al. 2003), a sua ocorrência nessa posição sugere uma deposição de 2 metros de sedimentos holocênicos sobre barreira pleistocênica.

2 - Os sambaquis são vistos como "entidades" praticamente não afetadas por processos de evolução morfodinâmica e sedimentar, estando em geral posicionados superficialmente aos substratos geológicos, e portanto, nunca inseridos ou interdigitados a camadas, fácies e sistemas deposicionais. Tal situação é facilmente constatada nos modelos clássicos de classificação dos tipos de substratos e posicionamento de sambaquis na costa sul-sudeste brasileira (Bigarella, 1954, Fairbridge, 1976), esquemas esses amplamente seguidos por arqueólogos e geológos costeiros (Martin et al., 1984; Suguio et al, 2005). Nesses modelos(Figura 10), os sambaquis acham-se dispostos apenas na superfície dos substratos costeiros, não participando dos eventos deposicionais ou erosivos, mas apenas acompanhando seus elementos geomórficos, de implicações paleogeográficas. A percepção de depósitos arqueológicos indiferentes aos processos geológicos e pedológicos atuantes por pelo menos 5.000 anos não encontra paralelo nos sítios registrados em áreas continentais, mesmo em locais abrigados e geologicamente estáveis. 


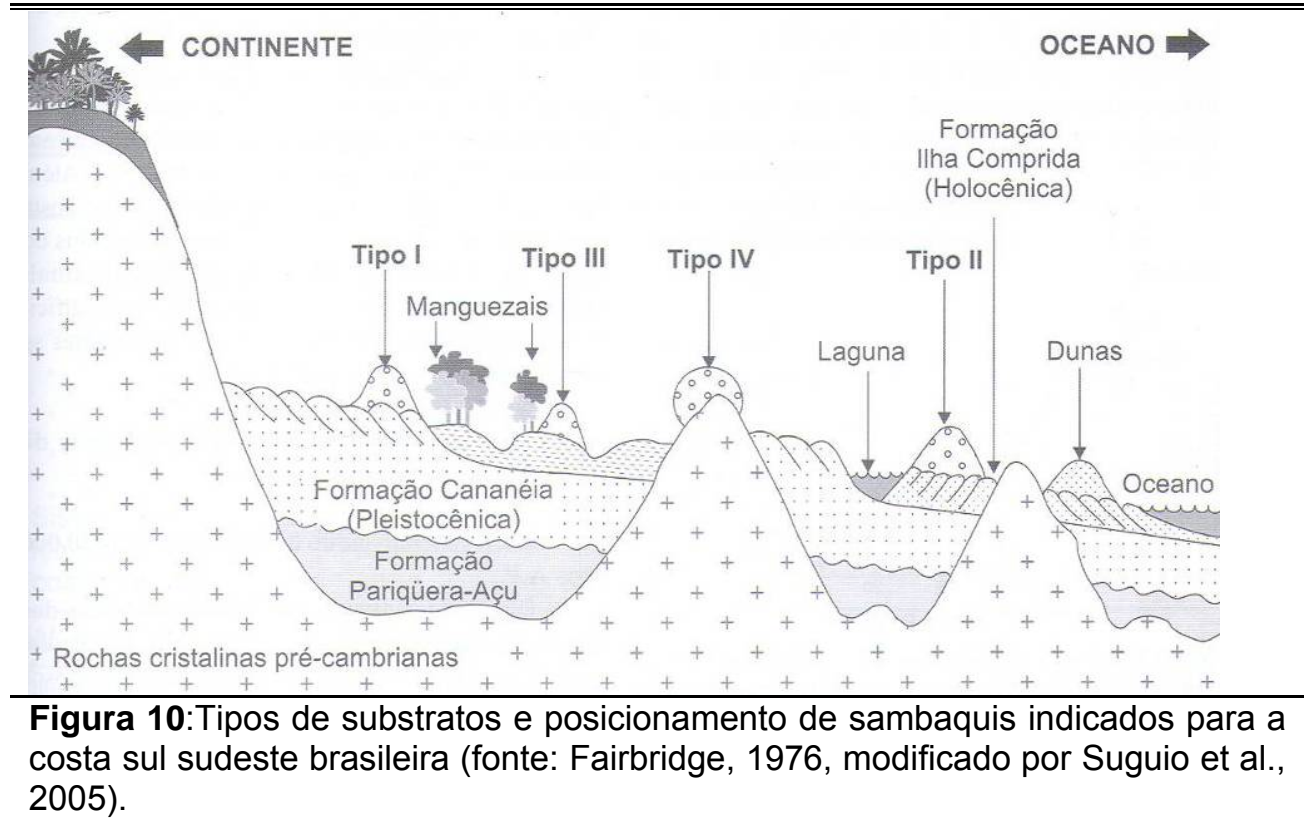

Por sua vez, as inúmeras evidências de processos de erosão/abrasão, de retrabalhamento ou presença de feições submersas junto a sambaquis (Oliveira, 2000; Brochier, 2004; Calippo, 2004); da constatação da profundidade de sítios líticos e cerâmicos encontrados no litoral (Chmyz, 1975, 2002; Chmyz et al, 2003); bem como, dos estudos sobre a dinâmica de recuos e progradações atuais da linha de costa (ex. Angulo, 1993; Soares et al., 1997; Souza et al, 2005) indicam a necessidade de repensar tais modelos e suas implicações sobre aspectos de interpretação arqueológica e geocosteira. Esta perspectiva também deve ser considerada nas hipóteses atuais sobre a demografia e complexidade social dos construtores dos grandes sambaquis da costa catarinense (DeBlasis et al. 1998), cuja comprovação implica na detecção de sítios habitacionais ou de atividades específicas no entorno.

Outras proposições para a região da baia de Guaratuba inserem-se no contexto das rotas ou de deslocamento, onde é possível visualizar a integração de modelos sobre a espacialidade de sambaquianos no litoral norte catarinense (OLIVEIRA, 2000; OLIVEIRA e HORN FILHO, 2001) com a perspectiva de capeamento sedimentar de sítios e identificação de corredores geoecológicos de ligação entre as baías citadas e áreas interioranas adjacentes (BROCHIER, 2001).

Neste aspecto, poucas pesquisas têm sido realizadas no litoral paranaense, a despeito da significativa importância que esta porção do território brasileiro representaria para estudos de caráter macro regional. Um dos fatores refere-se à problemática das origens, mobilidade e dispersão de grupos construtores de sambaquis ao longo da costa brasileira. Por exemplo, Kneip (1997, 1998 apud OLIVEIRA, 2000:28) e GASPAR (1996; 2000), tendo por base principalmente as informações geradas pelas datações radiocarbônicas inferem modelos de ocupação de pescadores-coletores-caçadores no litoral sul-sudeste, identificando um 
provável centro dispersor no atual estado do Paraná, há aproximadamente 6.500 anos AP. Para os autores, o deslocamento desses grupos para outros estados teria se dado de forma relativamente rápida, alcançando o Rio de Janeiro por volta de 5.500 anos AP.

Nesta perspectiva exploratória, OLIVEIRA (2000, 2001) propôs um modelo sobre a espacialidade dos sambaquianos e suas rotas de deslocamento, considerando o estudo geológico-evolutivo das possíveis ligações físicas entre antigas planícies fluvio-marinhas interiorizadas. O autor propõe que a região entre o rio São João (PR) e o canal do Palmital (SC) tenha sido uma área emissora inicial de expansão de grupos sambaquianos, oferecendo ainda condicionantes fisiográficos e ecológicos favoráveis ao deslocamento das primeiras populações sambaquianas entre as baías de Guaratuba e Babitonga (Figura 11). Supõe-se que em decorrência do rebaixamento do n.r.m. após 5.100 A.P, e da ativação da sedimentação fluvial, teriam se desenvolvido áreas propícias à contínua formação de baixios e bancos de moluscos, no sentido geral da regressão marinha. Atenta ainda para a existência de corredores naturais (como as bacias do Itapocu e Pirai) importantes para o entendimento da "integração e antecipação espacial" de grupos do litoral e interior, embora considere que "as características morfoclimáticas atuantes após o "ótimo climático" possam não ter permitido a preservação da cultura material nestas vias de ligação entre a planície e planalto" (op.cit. p. 39). 


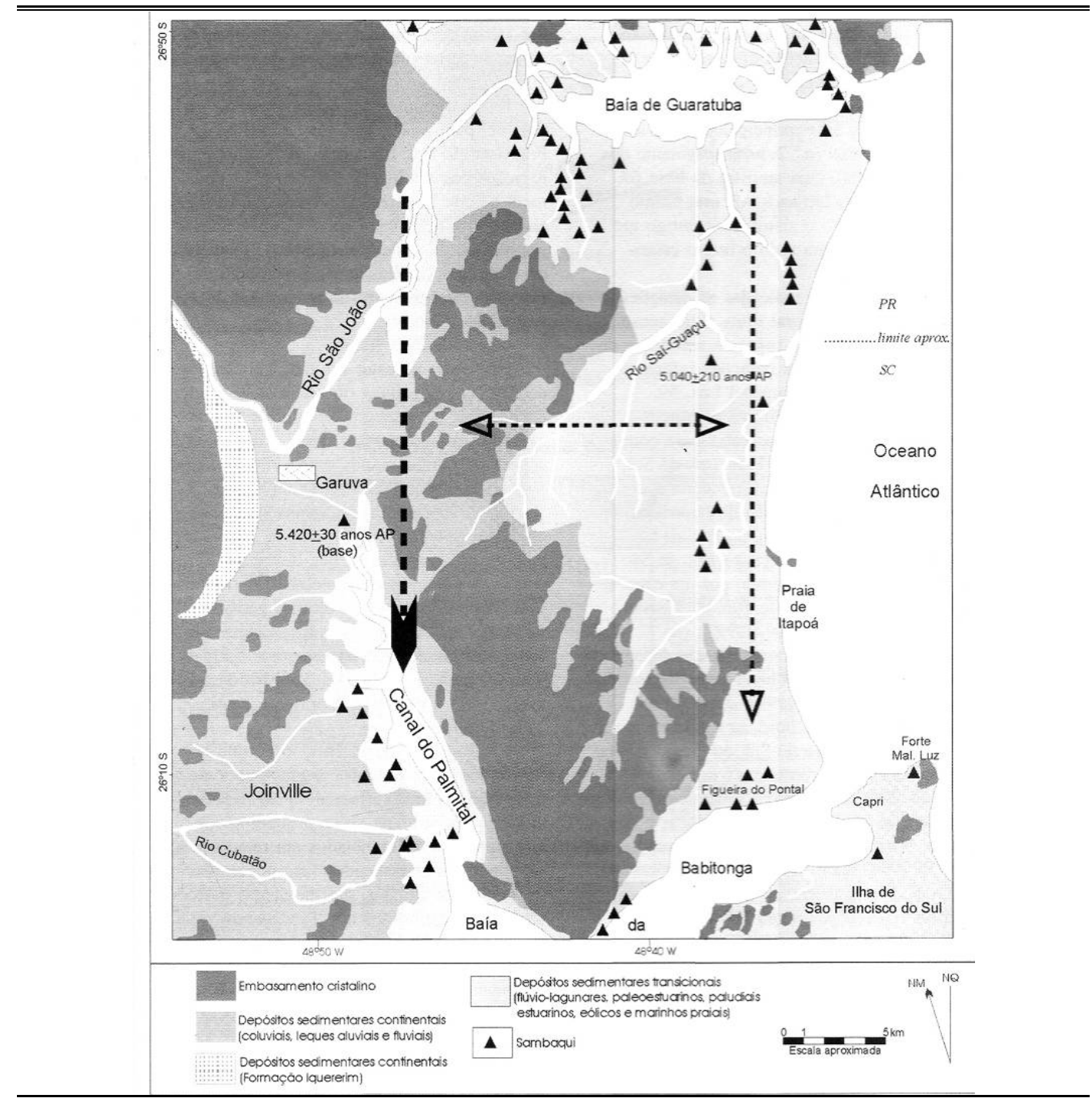

Figura 11:Mapa simplificado da planície costeira ente a Baía de Guaratuba e a Baía da Babitonga, com ênfase nas possível rota do Eixo São João/Palmital para o deslocamento de populações sambaquianas em os respectivos complexos estuarinos (retirado de OLIVEIRA e HORN FILHO, 2001, p.69)

Por sua vez, tendo por base estudos geocosteiros sobre a evolução paleogeográfica da planície costeira de Itapoá (SOUZA et all., 2001) é possível identificar outra alternativa ao eixo São João/Palmital, que pode ser chamado de eixo ou corredor geoecológico Itapoá. Conforme a configuração paleogeográfica desta planície durante o máximo da transgressão holocênica (Figura 12), a presença de extensos terraços do Pleistoceno, bem como, paleolagunas à retaguarda dos mesmos, permitiram inferir a existência de ilhas-barreira transgressivas (e, posteriormente cordões arenosos regressivos) que propiciaram a formação e a preservação do corpo lagunar e dos terraços antigos. Os depósitos paleoestuarinos desta antiga laguna se interceptam a norte, com depósitos similares existentes ao sul da baia de Guaratuba. No seu conjunto formariam, portanto, uma unidade geo-ecológica similar, com estuários e lagunas entremeados a terraços pleistocênicos. $\mathrm{O}$ padrão linear e a dissecação observada nesses terraços, que parece remeter aos antigos 
níveis marinhos do pleistoceno terminal, permitem supor condicionantes para detecção de sambaquis superficiais em seu entorno e a interceptação de sítios mais antigos, em subsuperfície.

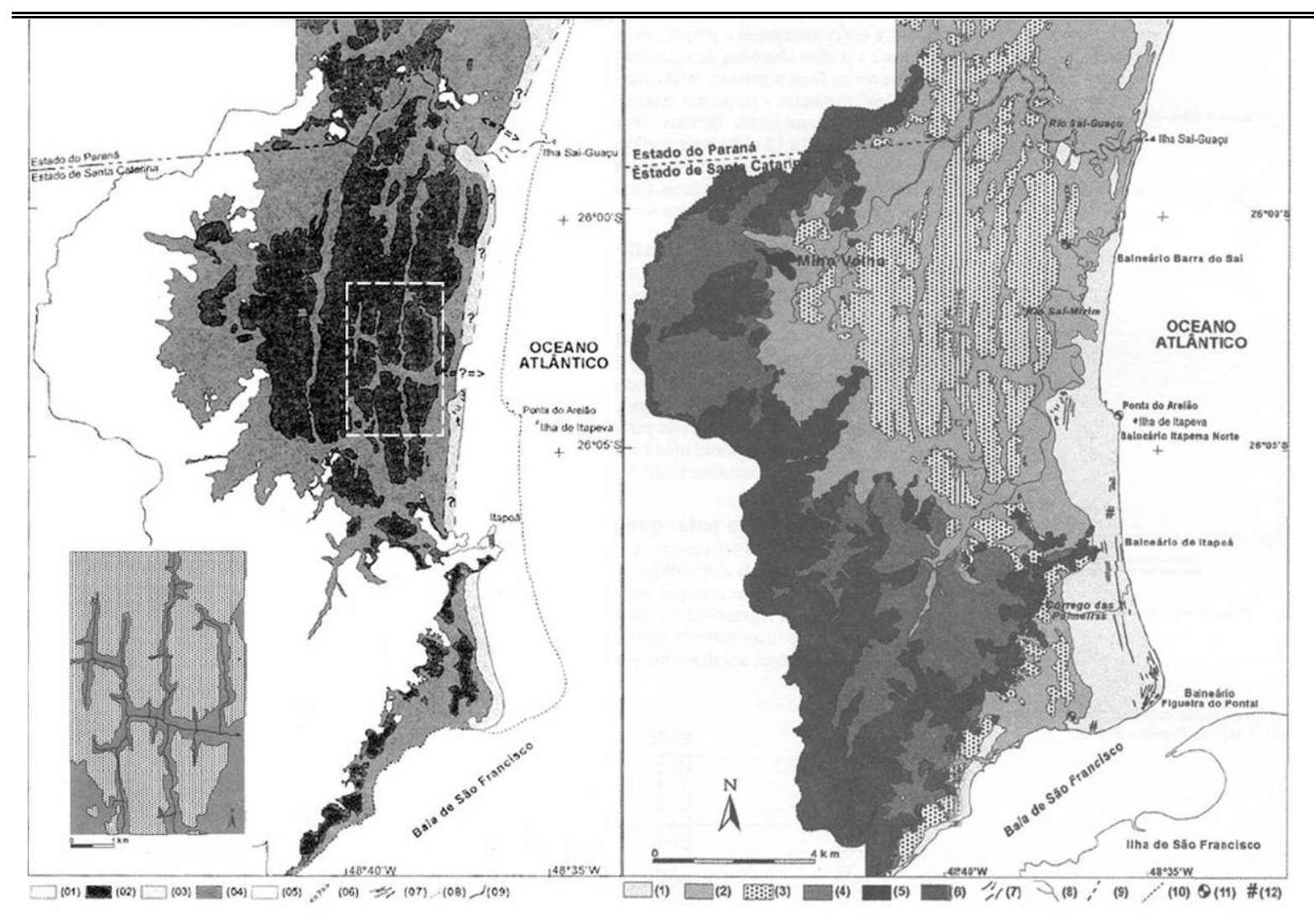

Figura 12: À esquerda: modelo da configuração paleogeográfica da planície costeira de Itapoá durante o máximo da transgressão holocênica - (1) rochas do embasamento e depósitos continentais indiferenciados; (2) terraços pleistocênicos; (3) barreira transgressiva e esporões holocênicos 4 - estuários e lagunas. À direita e detalhe à esquerda: Mapa geológico - (1) terraço marinho, praias e dunas holocênicos; (2) planícies paleoestuarinas e mangues holocênicos; (3) terraços pleistocênicos; (4) leques, terraços e planícies aluviais, colúvios; (5) sedimentos terciários (Mina Velha); (6) embasamento cristalino; (conforme (SOUZA et al., 2001, adaptado)

Finalmente, outro condicionante geoecológico da paisagem nesta região refere-se ao que poderia ser chamado de Corredor Garuva, que interliga as áreas costeiras com o planalto curitibano. Este corredor é representado pelo vale encaixado do rio São João que a partir de Tijucas do Sul, corta as vertentes da Serra do Mar, constituindo-se em uma das poucas áreas com boa acessibilidade e presença de terraços fluvial capazes de propiciar modelos para a detecção de antigas rotas entre o planalto e o litoral, ou vice-versa.

Assim a área costeira e sub-costeira entre as baías da Babitonga e de Guaratuba, apresenta, sob o ponto de vista da determinação de eixos e corredores, três importantes áreas de investigação (Figura 13). 


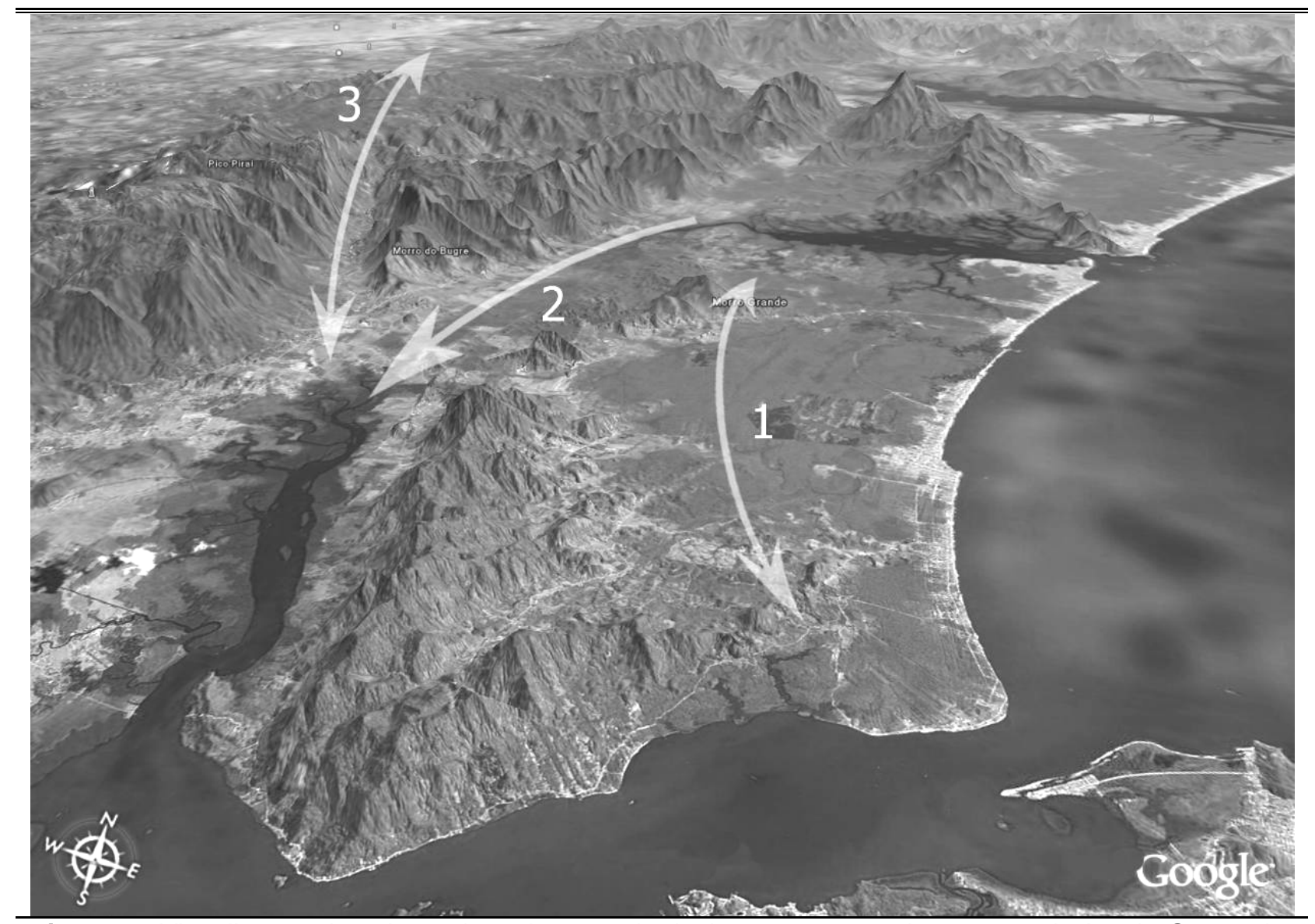

Figura 13:Visualização das alternativas de rotas de deslocamento costeiro entre as baías da Guaratuba e Babitonga. 1) Corredor de Itapoá; 2) Eixo São João-Palmital e 3) Corredor Garuva.

Considerando as problemáticas e perspectivas exploratórias indicadas acima é possível verificar o grande potencial para uso de controles geoarqueológicos na baía de Guaratuba, focados sobre as relações

A possibilidade de apontar áreas de preservação e interceptação de sítios costeiros em "armadilhas" (traps) geomórficas e sedimentares vem sendo debatida por Brochier (2001) para determinados sistemas costeiros ou subcosteiros (áreas continentais adjacentes à costa) na baía de Guaratuba (PR). Para os sítios mais antigos, estas armadilhas poderiam situar-se em cotas inferiores a -10 metros sob a atual planície costeira, dispondo-se, sobretudo, ao longo de antigos vales que foram profundamente dissecados durante o rebaixamento dos níveis de base no $L G M$ e, nas margens continentais de sistemas estuarinos formados por ocasião da elevação do n.r.m nos últimos 9.000 anos. Condicionantes geomórficos e morfodinâmicos específicos atuantes durante os ajustes no aporte e balanço sedimentar entre sistemas continentais e litorâneos, controlados por variações climáticas e pelas mudanças e velocidade de variação do nível relativo do mar, poderiam ter favorecido a preservação de fácies sedimentares transgressivas e regressivas, capazes de conter evidências arqueológicas. 
Modelos similares sobre potencial de preservação e descoberta de sítios costeiros antigos, vêm sendo considerados por diferentes autores (ver principalmente MASTERS; FLEMMING, 1983), embora grande parte deles enfoque as áreas atualmente submersas da plataforma continental e zonas de face litorânea e costa afora (nearshore - off-shore). $\mathrm{O}$ modelo conceitual mais significativo para a proposta de trapeamento de sítios, no entanto, é o apresentado por KRAFT et al. $(1983,109)$ para área da plataforma continental atlântica da costa de Delaware (Estados Unidos), cuja preocupação está na otimização dos dados sobre áreas submersas mais suscetíveis às migrações costeiras ao longo de antigos sistemas estuarinos. No bloco diagrama que ilustra o modelo dos autores (Figura 14) são apontadas cinco situações favoráveis à ocorrência de sítios em superfície e sua provável relação estratigráfica quando preservados em subsuperfície (devido à elevação do n.r.m). As setas escuras apontam para os pontos preferenciais para a procura de sítios submersos, que estejam no contato do substrato pré-holocênico com depósitos estuarinos, e que ao mesmo tempo, não estejam encobertos por espessas camadas de sedimentos (devido à proximidade com a superfície de erosão).

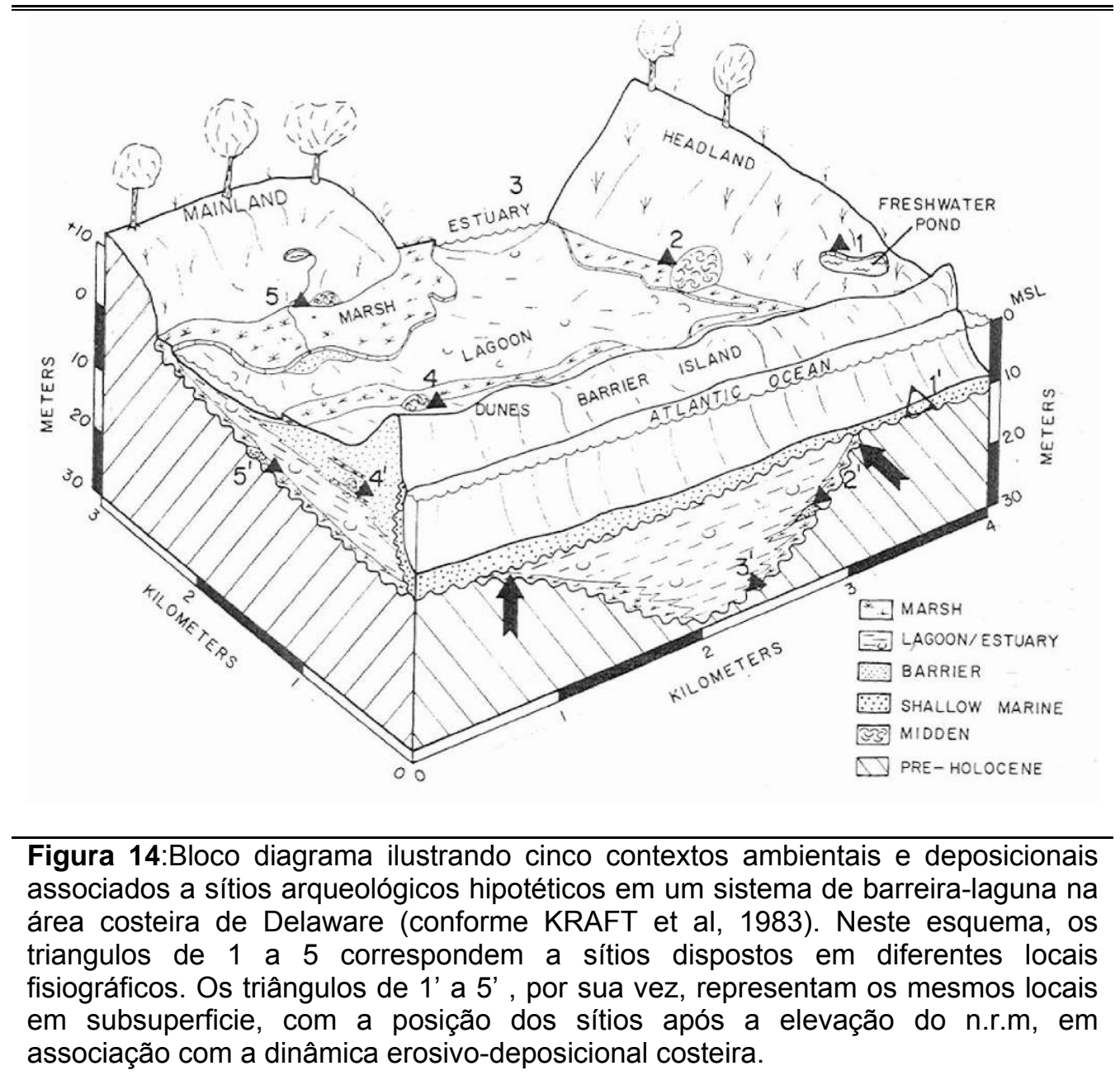


A possibilidade de uso do modelo acima em situações de ambientes e evolução morfodinâmica similares no litoral brasileiro compreende adaptações tais como, das diferenças nas curvas de variações do n.r.m; das características dos compartimentos geológico-geomorfológicos e, da evolução climática associada aos sistemas costeiros e subcosteiros. Assim, poderiam ser inseridos, os depósitos paleoestuarinos decorrentes das fases transgressivas e regressivas holocênicas, das relações com a dinâmica dos sistemas de encostas associados as vertentes da Serra do Mar e as possíveis variações climáticas capazes de alterar a relação entre aporte sedimentar e variações eustáticas, entre outros.

Neste sentido, pode-se verificar para a Costa Sudeste, situações específicas a serem testadas o que inclui a previsão da detecção de sítios costeiros em a) áreas submersas em pontos de antigos sistemas estuarinos; b) sob espessos depósitos sedimentares da planície costeira, atingindo por vez mais de 30 metros de espessura e; c) sob depósitos continentais de leques aluviais e coluvio-aluvionares.

No primeiros caso, a identificação de áreas favoráveis ao trapeamento de sítios remete a necessidade de estudos sobre coletas de sedimentos, sondagens com Jet Probe e vibrotestemunhadores, registros sísmicos e seções estratigráficas associadas a estuários potenciais ao longo da costa. Um exemplo neste sentido refere-se à seqüência de perfis estratigráficos transversais ao eixo do estuário de Paranaguá (Lessa et al. Apud SOARES et al, 1997). A preservação de camadas de lama trangressiva sobre um antigo vale fluvial indica, conforme o modelo apresentado por WATERS (1992), situações potenciais para a ocorrência de sítios com até 8.000 anos (Figura 15). 


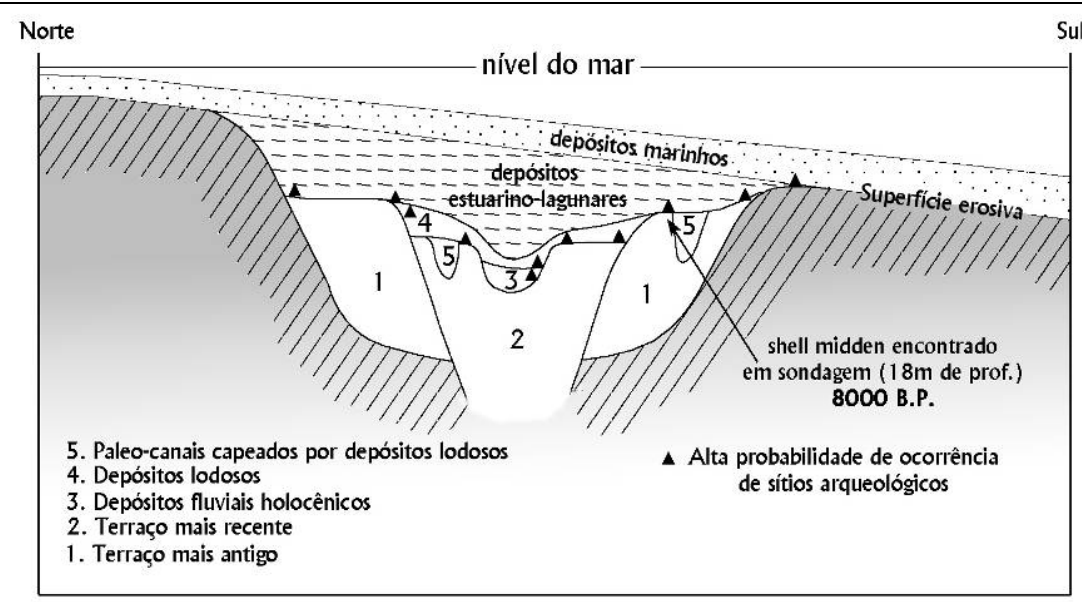

Modelo baseado em estudos da porção submergida do Sabine River Valley, costa de Lousiana.

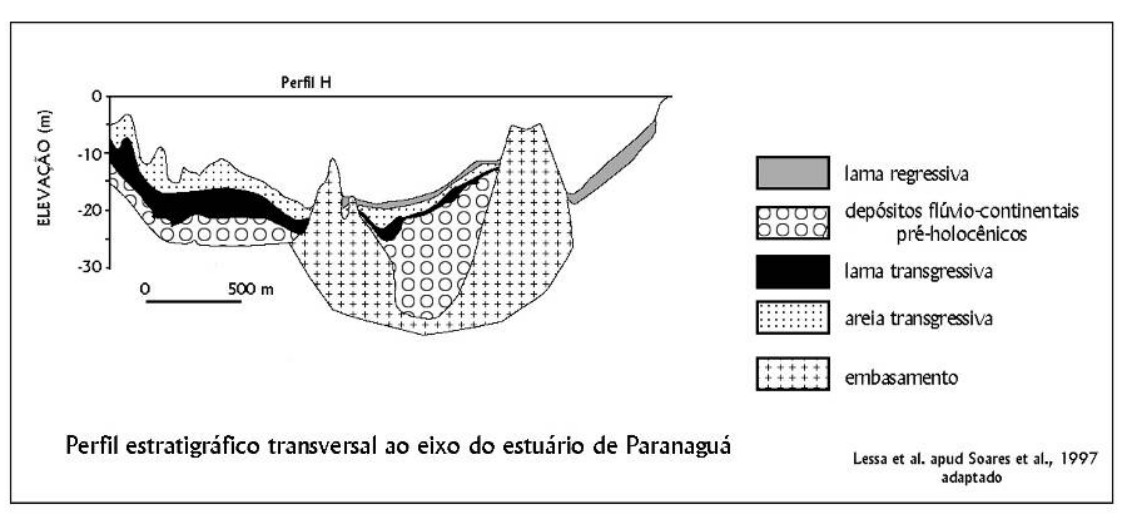

\begin{abstract}
Figura 15:Comparação do modelo de identificação de sítios arqueológicos em paleocanais capeados (Waters, 1992) e do perfil estratigráfico transversal ao eixo do estuário de Paranaguá (Lessa et al. Apud Soares et al, 1997, adaptado). Esta área parece apresentar condições propícias à detecção de sítios submersos e capeados.
\end{abstract}

O segundo ponto refere-se à possibilidade de detecção de sambaquis sob sedimentos profundos, na atual planície costeira. Conforme as correlações apresentadas na Figura 16, a presença de antigos sistemas estuarinos formados em vales encaixados, sob níveis marinhos de cota entre -20 e $-40 \mathrm{~m}$, e que adentrassem por grandes extensões no continente $^{40}$ (em distâncias entre 3 e 30 km do mar aberto, dependendo da configuração da plataforma), poderiam ter seus sedimentos dispostos sob a planície costeira atual, com potencial de interceptação de sítios de idades entre 8 e 9000 anos AP. Esta proposta também está ancorada nos modelos evolutivos (paleogeográficos) e estratigráficos para as áreas costeiras do Paraná e norte de Santa Catarina (LESSA \& ANGULO, 1995; SOUZA ET

\footnotetext{
${ }^{40}$ A exemplo dos atuais estuários brasileiros que adentram quilômetros para o interior das planícies costeiras, muito embora estejam em um contexto de costa regressiva,ou seja, ligados ao estabelecimento de um largo processo progadacional (LESSA, 2005).
} 
AL, 2001), datações de depósitos sedimentares costeiros e leques aluviais holocênicos (BESSA et al, 1997) ) e também em estudos paleoecológicos, que indicam incursões marinhas em vales intercordões durante o Holoceno inferior (BEHLING \& NEGRELLE, 2001).

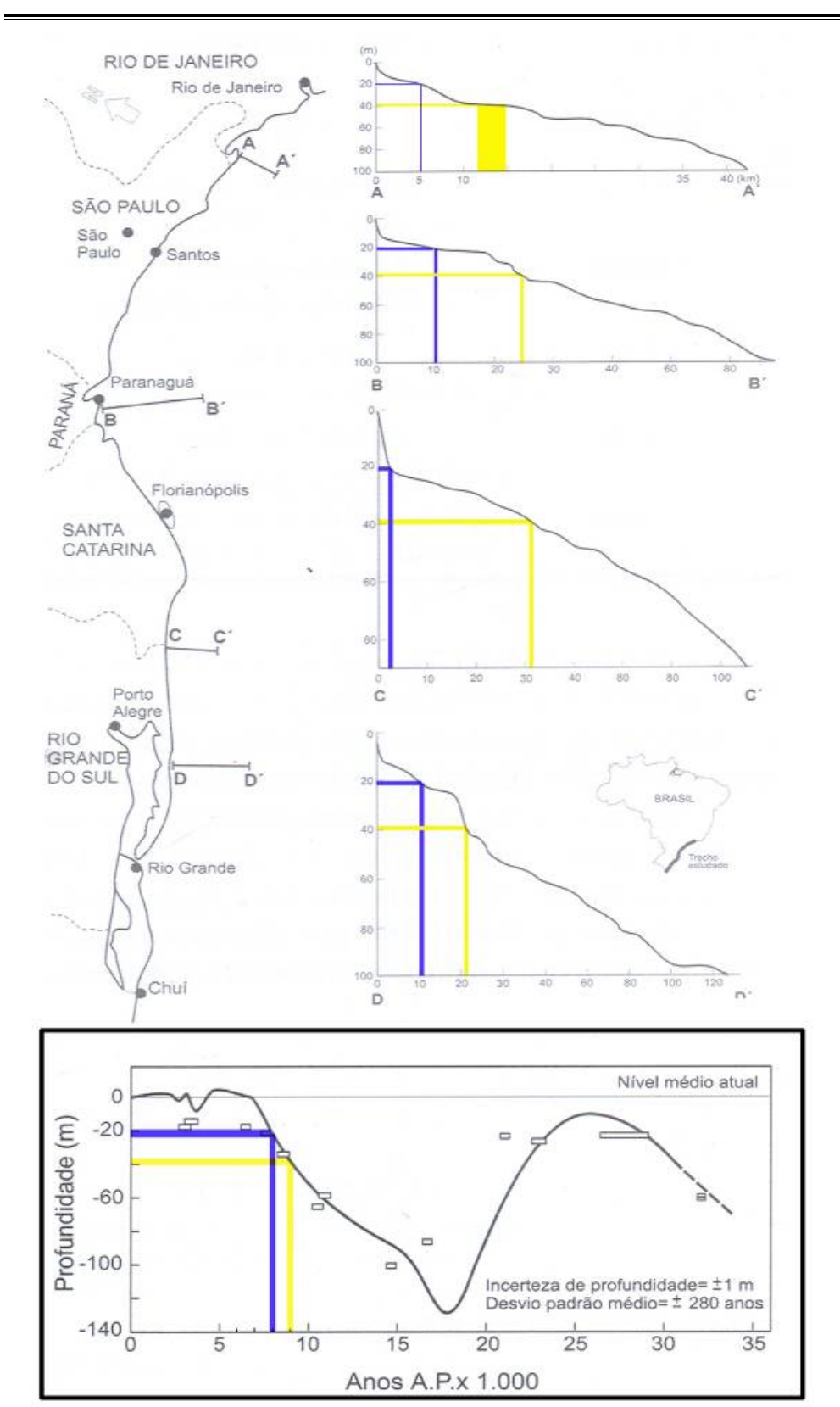

\footnotetext{
Figura 16: Correlação entre perfis batimétricos da plataforma costeira sul e sudeste com a curva de variações dos paleoníveis marinhos. (fonte CORRÊA, 1996, adaptado de figuras apresentadas por SUGUIO et al, 2005)
}

Finalmente um último aspecto a ser abordado refere-se à presença de leques aluvionares extensos como o do leque aluvionar do rio São João, posicionado no interior da baia de Guaratuba, que representa um dos maiores leques do litoral paranaense . Conforme BESSA 
et al (1997) as datas obtidas para amostras coletadas em leques próximos, como no caso dos leques aluviais do rio Colônia Pereira e do rio Cambará indicaram datas de 13.850 A.P. \pm 120 e 8.330 AP \pm 80 , respectivamente (Figura 17). A conformação do leque do rio Cubatão aparentemente sobre os depósitos paleoestuarinos da Baia de Guaratuba sugere, segundo ANGULO (1992), data holocênica para sua formação. Por sua vez, a relação do leque com os sambaquis georreferenciados na área da baía de Guaratuba (Figura 18) sugere condicionantes de trapeamento e dinâmica erosivo-deposicionais importantes para o estudo de sítios (Figura 19) situados próximos ao hipotético eixo São João Palmital .

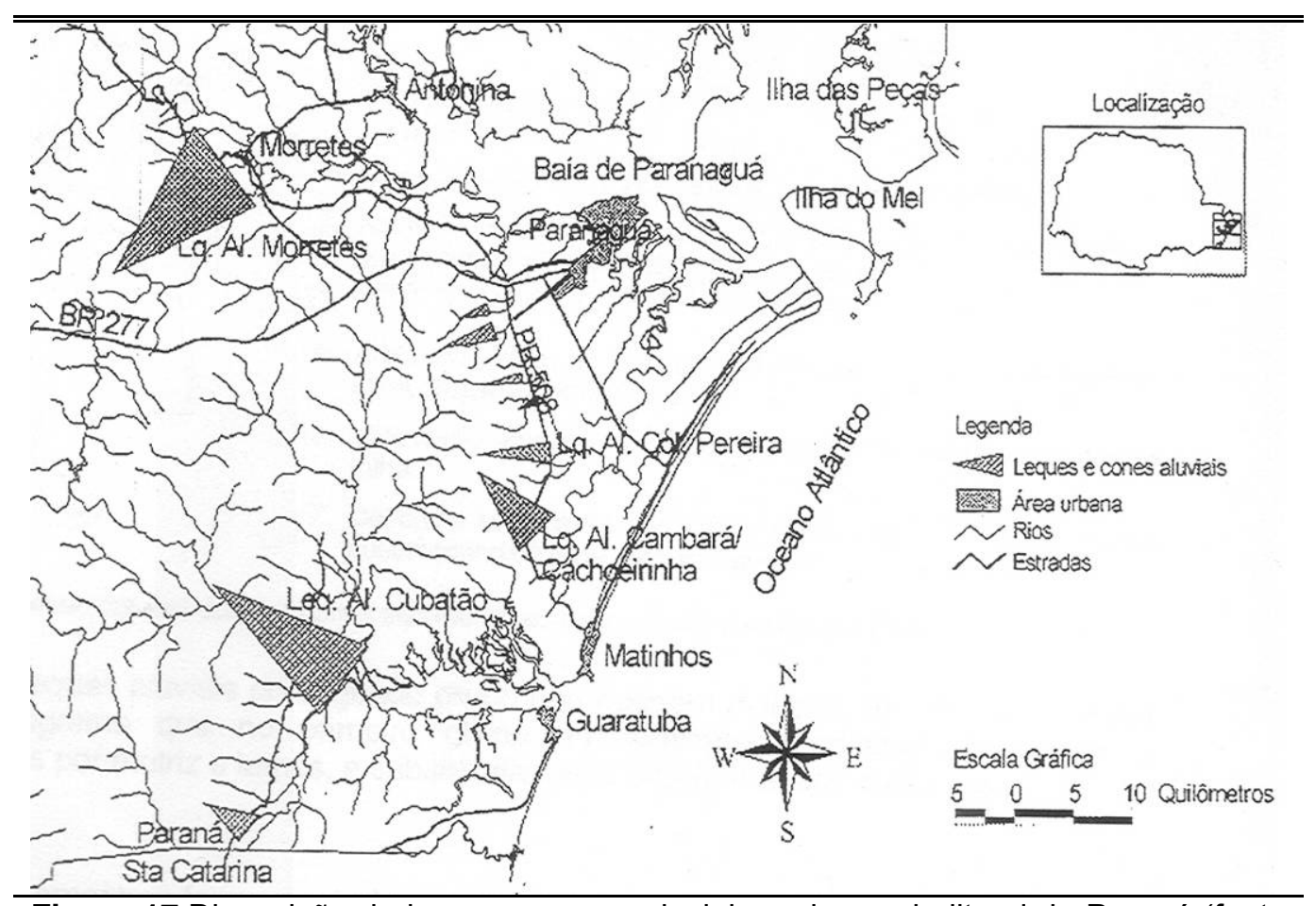

Figura 17:Disposição de leques e cones aluviais ao longo do litoral do Paraná (fonte BESSA, 1997) 


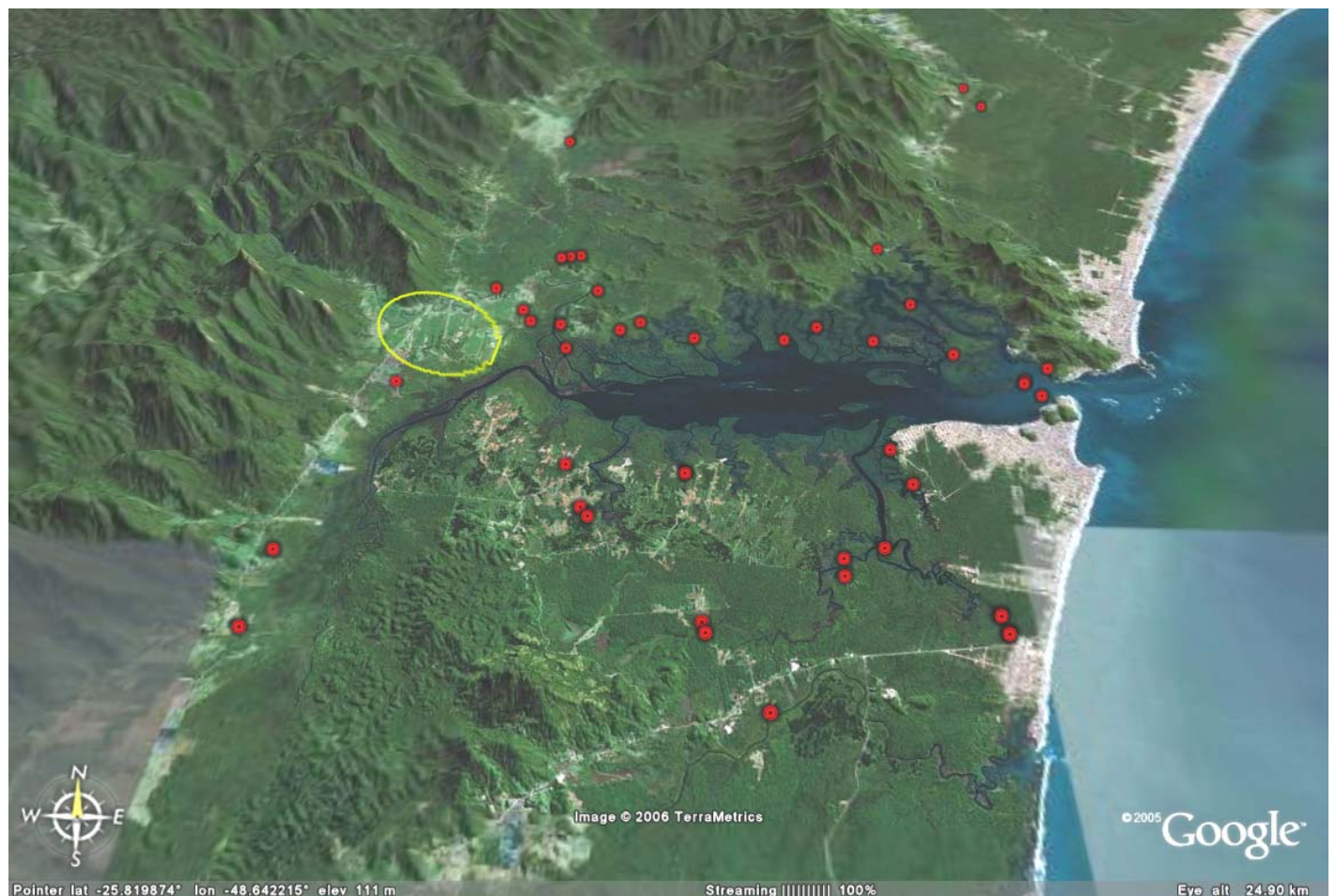

Figura 18:Disposição do leque aluvial do rio Cubatão e o posicionamento de sambaquis georreferenciados na área da baía de Guaratuba.

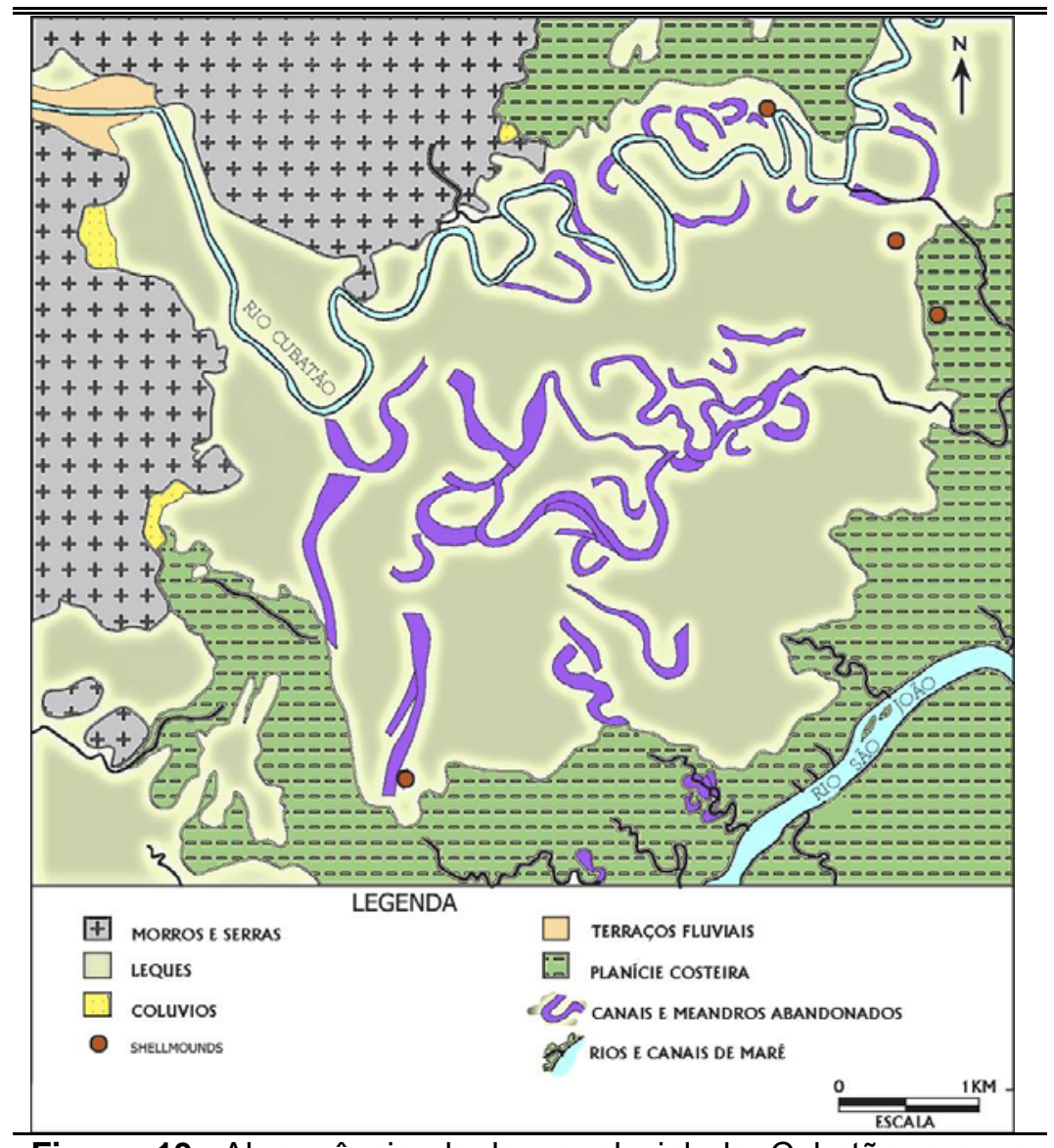

Figura 19: Abrangência do leque aluvial do Cubatão e seus diferentes ciclos de migração de meandros 


\subsection{AsPeCtos geraIS E O LEVANTAMENTO DE SAMBAQUIS NA BAIA DE GUARATUBA}

A Baía de Guaratuba localiza-se na porção sul da planície costeira do Estado do Paraná, entre as coordenadas $25^{\circ} 45^{\prime}$ e $26^{\circ} 00^{\prime}$ de latitude sul e entre $48^{\circ} 34^{\prime}$ e $48^{\circ} 50^{\prime}$ de longitude oeste, compreendendo ampla rede hidrográfica onde se destacam os rios Cubatão, São João e Boguaçu, além das demais drenagens provenientes da planície costeira e do complexo de vertentes da Serra do Mar. Possui uma área de $50,19 \mathrm{Km}^{2}$, apresentando seu eixo principal orientado no sentido leste-oeste, com extensão máxima $15 \mathrm{~km}$ e largura de aproximadamente $5 \mathrm{~km}$. A comunicação com o Oceano Atlântico é feita por uma única e estreita desembocadura (aproximadamente $500 \mathrm{~m}$ ), limitada por pontais rochosos. A maré da Baía é do tipo semidiurna com desigualdades diurnas e registros indicando alturas média de sizígia e quadratura de $1.5 \mathrm{~m}$ e $0.7 \mathrm{~m}$ respectivamente (SOARES et al. 1995).

A vegetação é constituída pela Floresta Ombrófila Densa (Floresta Atlântica) e ecossistemas associados (mangue, restinga e vegetação de altitude), conservada principalmente em Unidades de Conservação. A Baía de Guaratuba está inserida na APA (Área de Proteção Ambiental) de Guaratuba, compreendendo ainda em seu interior, outras Unidades de Conservação como o Parque Nacional Saint Hilaire-Lange e o Parque Estadual do Boguaçu.

\subsubsection{Histórico das principais pesquisas de enfoque geoarqueológico e geológico-evolutivos;}

Alguns critérios relacionados a distribuição espacial e cronológica dos sambaquis, variações no conteúdo malacológico, disponibilidade e proximidade de bancos de moluscos, bem como, o substrato geológico ao qual está assentado, têm sido amplamente utilizados como indicadores das oscilações do nível relativo do mar durante o Holoceno no Brasil (KRONE, 1908; LEONARDOS 1938; BIGARELLA, 1954; FAIRBRIDGE,1976; MARTIN ET AL. 1984; PROUS, 1991; FIGUTI, 1993; GASPAR, 2000). Entretanto, mais recentemente, tem havido debates entre geólogos costeiros (ANGULO \& LESSA, 1997, MARTIN et al. 1998, LESSA \& ANGULO, 1998), que apontam problemas interpretativos e restrições ao uso direto das informações geradas por sambaquis com esse propósito. Apesar da ainda discreta participação de arqueólogos nesta discussão, tais questões vem estimulando, conforme OLIVEIRA (2001:55), a retomada de pesquisas voltadas ao entendimento das razões culturais de implantação dos sítios, processos de construção e transformação pósdeposicionais. Outros pontos referem-se ao entendimento dos processos de migração, mobilidade/circulação e fixação de grupos pescadores-coletores-caçadores frente aos 
aspectos de dinâmica e evolução da linha de costa, permitindo a produção de dados de maior confiabilidade que permitam uma sinergia entre estudos arqueológicos e geocosteiros. Neste sentido, conforme GASPAR (2000:16) "a análise da evolução costeira tem resultado também em uma indispensável reconstituição ambiental, permitindo que se tenha uma noção da feição dos locais escolhidos pelos sambaquieiros para erigir os sítios." Contudo, os trabalhos sobre a evolução paleogeográfica são ainda escassos, destacando-se no Paraná e na região norte Catarinense os trabalhos de Bigarella (1946, 1954), os mapeamentos de FUCK et al. (1969), MARTIN et al. (1988) e ANGULO (1992, 2004) e, estudos da evolução das barreiras por LESSA et al. (2000), SOUZA et al. (2001) e SOUZA (2005). Entretanto, ainda "diversos aspectos da evolução paleogeográfica da região devem ser elucidados" (ANGULO et al., 2005).

Em termos de proposições explanatórias do ponto de vista "geoarqueológico", o litoral sul-sudeste compõe um histórico importante de associação entre estudos costeiros e pesquisas em sambaquis no Brasil. Como primeira referência está o estudo de Krone (1908) que postulou a associação entre o conteúdo malacológico dos sambaquis e as variações do nível do mar, implicando em relações de antiguidade dos sítios. Outro pioneiro foi BIGARELLA (1946, 1949; BIGARELLA et al. 1954, entre outros), que a partir da década de 40, aplicou abordagens geológicas e paleogeográficas à compreensão dos sambaquis e à evolução litorânea nos estados do Paraná e Santa Catarina. As informações sobre flutuações climáticas e marinhas apontadas pelo autor também favoreceram o desenvolvimento de explicações sobre aspectos de antiguidade, ocupação e subsistência de grupos sambaquianos e, hipóteses sobre a variabilidade composicional e dos vestígios culturais encontrados nesses sítios.

Sobre as formações geológicas onde são encontrados sambaquis Emperaire e LAMING (1954/56), por exemplo, procuraram estabelecer idades relativas de alguns sambaquis do Paraná e São Paulo, tomando por base a elevação do seu substrato em relação ao nível médio do mar. BIGARELLA (1954:208) estabelece os primeiros parâmetros em termos locacionais, correlacionando os sambaquis com 5 diferentes tipos de terrenos geológicos: a) margem de tabuleiros arenosos; b) ilhas arenosas ou areno-argilosas, em meio a terrenos pantanosos; c) sobre afloramentos rochosos; d) No meio de terrenos pantanosos e; e) no meio de terrenos arenosos. Outras classificações desta natureza foram formuladas por FAIRBRIDGE (1976) e SUGUIO (1993). MARTIN et al. (1984) corroboram a perspectiva de Bigarella (1954) ao considerarem que a determinação do substrato pode contribuir para estimativas do intervalo de tempo onde o sambaqui foi construído. Hurt e BLASI (1960:43) apresentaram uma classificação adicional, com base nas características atuais da linha de ação das águas marinhas: sambaquis localizados ao longo de bancos de rios que constantemente sofrem influência das marés; ao longo da linha d'água das baias; 
localizados em ilhas e; ao longo das praias oceânicas. Estes autores também abordaram aspectos sobre correlações entre os níveis altimétricos de antigas praias e a construção de sambaquis, considerando que mudanças na composição conchífera não estavam associadas a sua antiguidade, como apregoava Krone, mas seriam importantes indicadores de zonas ecológicas.

Quanto ao registro de sambaquis, no Paraná, os levantamentos de BIGARELLA (1950/51 a, b), RAUTH (1974 a, b), POSSE (1978), BLASI et al. (1987), MARTIN et al (1988), PARELADA e MACEDO (1987), PARELLADA (1989 a, b), ANGULO (1992), CHMYZ (com. pessoal, 1999) e BROCHIER $(2002,2004)$ indicam a ocorrência de 298 sítios dessa natureza, sendo que destes, somente 13 teriam sido objeto de pesquisas sistemáticas com escavações parciais. Para o litoral sul (que compreende a baía de Guaratuba) são pontuados 100 sambaquis, sendo que apenas três sítios foram escavados (Ilha dos Ratos, Araújo II e Matinhos II). As datações existentes para o Paraná (quadro 1) indicam que a construção de sambaquis abrangem um amplo período, deste aproximadamente 6.500 anos A.P. até 1500 anos A.P.

Quadro 3: Datações de sambaquis no Litoral Paranaense

\begin{tabular}{|c|c|c|c|c|}
\hline Sambaqui & Localização & Datação (anos A.P.) & Método & Referência \\
\hline Godo & $\begin{array}{l}\text { Baia de Antonina } \\
\text { (Baia } \\
\text { Paranaguá) }\end{array}$ & $\begin{array}{l}4.740 \pm 95 \\
4.500 \pm 190 \\
2.980 \pm 130\end{array}$ & Radiocarbônico (C14) & Rauth, 1974 \\
\hline Gomes & Baía de Paranaguá & $\begin{array}{l}4.877 \pm 64 \\
4.490 \pm 136\end{array}$ & Radiocarbônico (C14) & Rauth, 1969 \\
\hline $\begin{array}{l}\text { Guaraguaçu A } \\
\text { Guaraguaçu B }\end{array}$ & $\begin{array}{l}\text { Baía de Paranaguá } \\
\text { Baía de Paranaguá }\end{array}$ & $\begin{array}{l}4.220 \pm 200 \\
4.128 \pm 260\end{array}$ & $\begin{array}{l}\text { Radiocarbônico (C14) } \\
\text { Radiocarbônico (C14) }\end{array}$ & $\begin{array}{l}\text { Menezes, } 1968 \\
\text { Laming, } 1968\end{array}$ \\
\hline Ilha dos Ratos & Baia de Guaratuba & $1.540 \pm 150$ & $\begin{array}{l}\text { Radiocarbônico (C14) } \\
\text { (Gif) }\end{array}$ & Garcia, 1979 \\
\hline Macedo & Baía de Paranaguá & $\begin{array}{l}3.570 \pm 60 \\
3.357 \pm 58 \\
3.754 \pm 52 \\
3.677 \pm 61\end{array}$ & Radiocarbônico (C14) & Blasi, 1963 \\
\hline Porto & Baía de Paranaguá & $3.150 \pm 110$ & Radiocarbônico (C14) & Garcia, 1979 \\
\hline Porto Maurício & Baía de Paranaguá & $\begin{array}{l}6.030 \pm 130(1) \\
4.760 \pm 80(2) \\
4.540 \pm 90(2)\end{array}$ & $\begin{array}{l}\text { Radiocarbônico (C14) } \\
\quad(\text { SI-509 / SI-506) }\end{array}$ & $\begin{array}{l}\text { (1) Garcia, } 1979 \\
\text { (2) Rauth, 1969b }\end{array}$ \\
\hline Ramal & Baía de Paranaguá & $\begin{array}{l}6.540 \pm 105 \\
5.040 \pm 90\end{array}$ & $\begin{array}{l}\text { Radiocarbônico (C14) } \\
\text { (SI-1573 / SI-1572) }\end{array}$ & Garcia, 1979 \\
\hline São João & $\begin{array}{l}\text { Baia de } \\
\text { (Baia } \\
\text { Paranaguá) }\end{array}$ & $\begin{array}{l}4.960 \pm 110 \\
4.665 \pm 90\end{array}$ & Radiocarbônico (C14) & Rauth, 1974 \\
\hline Saquarema & Baía de Paranaguá & $\begin{array}{l}4.450 \pm 64 \\
4.384 \pm 64 \\
4.256 \pm 62 \\
3.965 \pm 66 \\
3.858 \pm 60\end{array}$ & Radiocarbônico (C14) & Hurt, 1964 \\
\hline Descoberto IV & Baía de Guaratuba & $4.500 \pm 190$ & $\begin{array}{c}\text { Radiocarbônico (C14) } \\
\text { (Bah.1275) }\end{array}$ & Martin et al., 1988 \\
\hline Almeida II & $\begin{array}{l}\text { Baia das } \\
\text { Laranjeiras (Baia de } \\
\text { Paranaguá) }\end{array}$ & $3.830 \pm 190$ & $\begin{array}{c}\text { Radiocarbônico (C14) } \\
\text { (Bah.1390) }\end{array}$ & Martin et al., 1988 \\
\hline Matinhos I & $\begin{array}{l}\text { Prox. Baía de } \\
\text { Guaratuba }\end{array}$ & $2.750 \pm 250$ & $\begin{array}{l}\text { Termoluminescência } \\
\text { (TL) (LACIVID-USP) }\end{array}$ & Chmyz, 2003 \\
\hline
\end{tabular}


Entretanto alguns levantamentos identificaram locais com presença de materiais culturais distintos dos sambaquis (BIGARELLA, 1950/51 a, b; RAUTH, 1963; CHMYZ, 1975, 1976, 1986; BLASI et al. 1987), que incluem a ocorrência sítios líticos, cerâmicos e históricos. De grande interesse são os poucos registros de tradições líticas ligadas ao planalto, como aqueles identificados no litoral central, no município de Paranaguá e no litoral sul, nos Municípios de Matinhos (CHMYZ, 1975, CHMYZ et al. 2003) e Guaratuba (BROCHIER, 2002). CHMYZ et al. (2003) interpretam as ocorrências recuperadas na década de 1970 no sambaqui de Matinhos, como vestígios de reocuparão desse sítio por caçadores-coletores do interior, portadores de pontas de projétil pedunculadas.

No levantamento de campo efetuado por BROCHIER (2002) foram escolhidos setores amostrais na APA de Guaratuba, notadamente aqueles com maior influência de atividades antrópicas recentes (identificados na carta de uso e ocupação dos solos). Outros setores pesquisados correspondem às faixas de terras próximas aos corpos d'água da baía de Guaratuba.

Os trabalhos constaram da vistoria de sítios arqueológicos indicados pela bibliografia e, da prospecção oportunística de vestígios culturais, principalmente em locais pouco conhecidos arqueológicamente.

Assim, foram plotados e avaliados 73 locais com presença de vestígios arqueológicos sendo que destes, 45 referem-se a sambaquis; 3 a sítios líticos; 3 a sítios cerâmicos indígenas (associados a tradição Itararé); 2 tipo "oficina lítica" (áreas de abrasadores, polidores e afiadores em suporte rochoso), 11 sítios cerâmicos históricos antigos (tradição Neobrasileira) e 2 tipo ruína histórica (ambos sub-recentes). Também ocorreram 7 pontos referendados como "indícios de interesse arqueológico", sendo caracterizados pela presença de vestígios isolados ou sem filiação cultural definida.

Também ocorreram muitas reocupações (mais de um tipo cultural no mesmo sítio) como é o caso da tradição Tupiguarani (3 ocorrências), observada nas camadas superficiais de sambaquis.

Os materiais arqueológicos encontrados freqüentemente referem-se a vestígios de pedra (refugo de lascamentos, ponta de projétil, artefatos polidos, pedras de fogueiras, bacias de polimento, etc.), vestígios cerâmicos (fragmentos de vasilhames indígenas, louças e telhas goivas, etc.), depósitos conchíferos e de terra preta e vestígios ósseos (de peixes, mamíferos, humanos), entre outros.

Os vestígios culturais foram visualizados na superfície do terreno, em abrigos rochosos, sob camadas de solos ou sedimentos ou mesmo de forma bem ressaltada na paisagem como é caso de muitos sambaquis. Os sítios estavam assentados sobre depósitos aluviais, coluviais 
e marinhos, tanto na encosta íngreme, quanto em ambientes de planície de maré. As áreas de ocorrência variaram de pontual até $190 \times 100 \mathrm{~m}$. No caso dos sambaquis foram verificadas desde acumulações rasas ao nível do solo até depósitos com aproximadamente $20 \mathrm{~m}$ de altura.

A constatação de diferentes configurações nos sítios arqueológicos remete a diversidade cultural, variação nas áreas de atividades (acampamentos, aldeias, áreas de obtenção de matéria prima, etc.), e a fatores geológicos (erosão, mudanças paleogeográficas) ou antrópicos (desconfiguração de sítios pelo uso e ocupação do solo).

Foram realizados estudos comparativos entre as coordenadas dos sítios plotados em campo (uso de GPS) e publicações anteriores. Os erros verificados variaram de 56 a 2575 metros, com média em torno em torno de $300 \mathrm{~m}$. Essas diferenças refletem possivelmente a utilização de uma base cartográfica ruim e a falta de equipamentos de precisão para o posicionamento geográfico.

Com base nas correlações acima foi possível identificar 33 novos sítios arqueológicos para a Baia de Guaratuba e imediações próximas, que somados aos 99 citados em bibliografia, totalizam 132 sítios arqueológicos. Dentre os novos, 12 são sambaquis; 11 sítios cerâmicos tipo Neobrasileiro; 3 cerâmicos tipo Itararé; 3 líticos; 2 histórico sub-recente. Também estão incluídos nesta listagem 2 sítios tipo "oficina lítica" junto a praia das Caieiras em Guaratuba que, embora existam indicações de sua existência, nunca tinham sido mapeados ou identificados como sítios arqueológicos.

Com base nos novos conhecimentos acima, foi elaborado um mapa de sítios arqueológicos da Baía de Guaratuba (Figura 20), tendo por referencias principais Bigarella (1954); Angulo (1992); Brochier (2002) e Chmyz (2007). 
MAPA GEOLÓGICO E DE SÍTIOS ARQUEOLÓGICOS DA BAÍA DE GUARATUBA - PR

Adaptado de Bigarella (1954); Angulo (1992) e Brochier (2002)

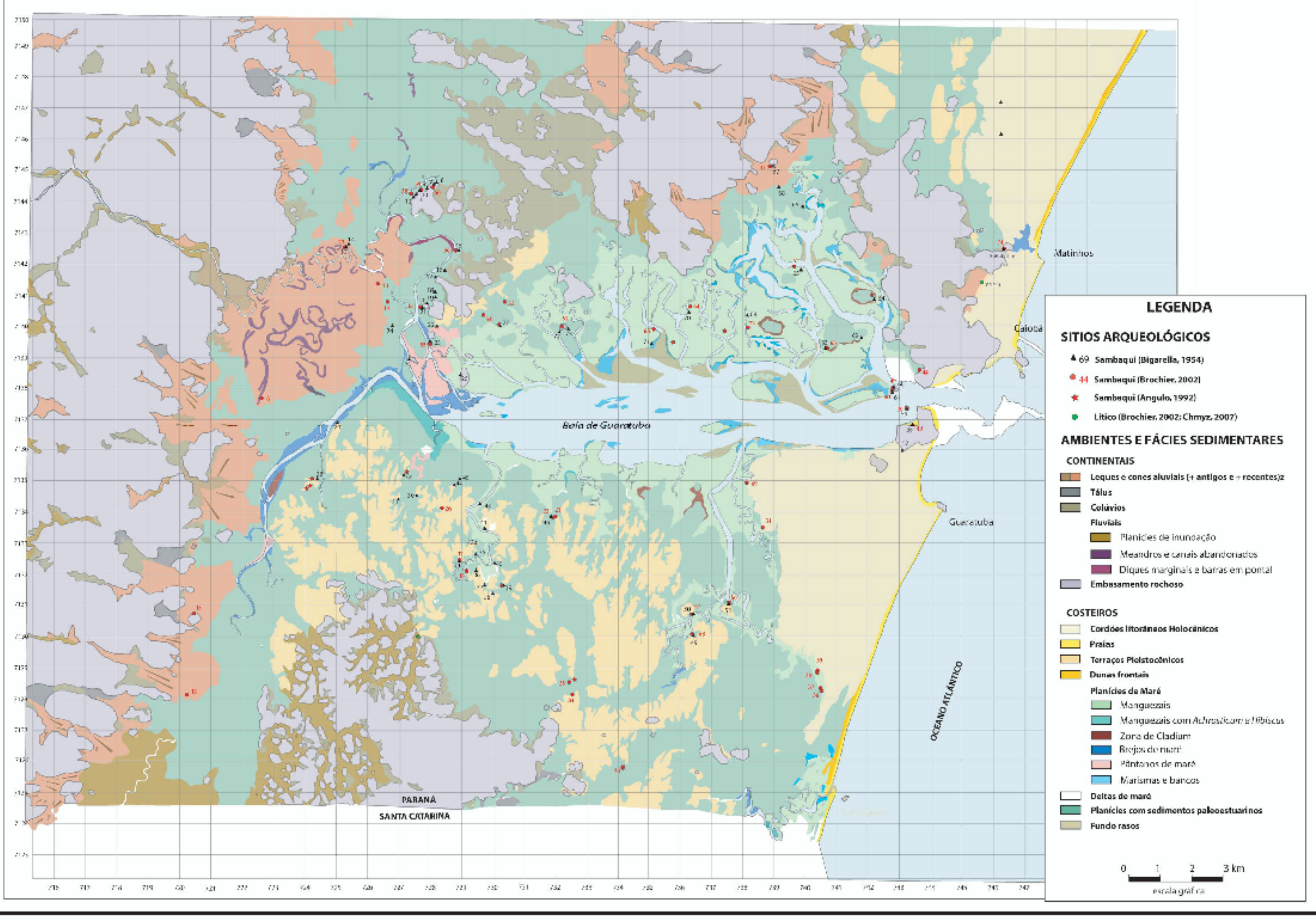




\subsection{A DinÂMICA SEDIMENTAR E EVOLUTIVA EM CARAgUATATUBA: UM CASO DE CONTROLE EM ZONAS DE TRAPEAMENTO}

\subsubsection{A Pesquisa de processos evolutivos e sítios profundos em Caraguatatuba}

Este item compreende a apresentação dos levantamentos prospectivos realizados pelo autor em conjunto com estudos de consultoria, relativos a dois projetos arqueológicos seqüenciais, a saber, "Projeto de Prospecção Arqueológica na área da Unidade de Tratamento de Gás de Caraguatatuba UTGCA-Petrobras" (SCIENTIA, 2007) e "Projeto de Prospecção Arqueológica Profunda, Monitoramento Arqueológico e Educação Patrimonial na Área Industrial da Unidade de Tratamento de Gás de Caraguatatuba -UTGCA" (ALASCA, 2008). O empreendimento em questão denominado "Unidade de Tratamento de Gás de Caraguatatuba (UTGCA)" constitui parte do Plano Estratégico da Petrobrás S.A. que tem por objetivo viabilizar o desenvolvimento do Campo de Mexilhão (jazida de gás descoberta em 2003, situada offshore na Bacia de Santos, constituindo a maior reserva brasileira de gás natural, com reservas estimadas de 400 bilhões de $\mathrm{m}^{3}$ ). Seu sistema de produção e escoamento de gás natural inclui: plataforma de produção, duto de escoamento até o continente, unidade de tratamento de gás e gasoduto de transporte. A área da UTGCA, situada junto à planície costeira de Caraguatatuba-SP constitui o local selecionado para a chegada do gás, desde o campo marítimo, permitindo a realização do processo de tratamento para posterior transporte até Taubaté-SP, via gasoduto.

Quanto à planície costeira de Caraguatatuba apresenta uma superfície de cerca de $12 \mathrm{~km}$ de extensão e $7 \mathrm{~km}$ de largura, constituindo uma área sedimentar disposta em meio a relevos íngremes e recortados da serra, mas que na seu contato com a linha de costa, forma um arco praial relativamente expressivo e que destoa das pequenas enseadas adjacentes. Esta planície constitui, portanto, a feição sedimentar mais expressiva entre São Sebastião e o limite como o Estado do Rio de Janeiro, embora seus depósitos quaternários ainda não sejam comparáveis com aqueles do litoral sul (Figura 21). Um mapa contendo as principais formações quaternários foi apresentada por Cruz (1974) onde podem ser distinguidos aspectos topográficos e morfológicos bem como as principais formações sedimentares superficiais (solo aluviais e coluvio-aluviais, areias marinhas e altos terraços, areias praiais, etc). Esta autora discute em profundidade os aspectos dos eventos ocorridos em 19 


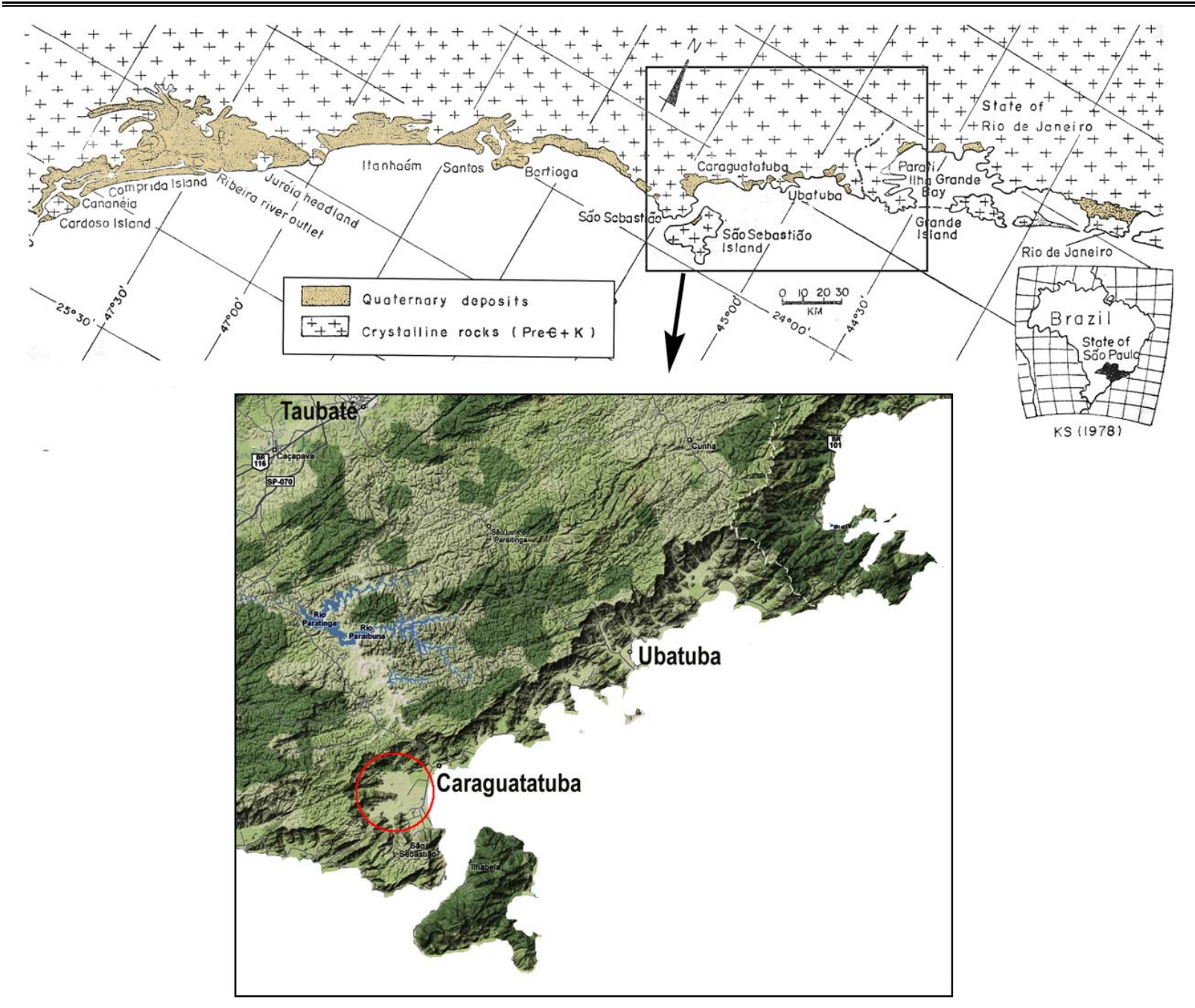

Figura 21: Mapa de distribuição dos depósitos quaternários na planície costeira do estado de São Paulo e a localização da planície costeira de Caraguatatuba, no local previsto para a futura instalação da UTGCA/Petrobrás.

Os projetos acima, embora ligados ao licenciamento ambiental de empreendimentos, ou seja, em um contexto de arqueologia de contrato, revelou-se promissor em termos de suas conseqüências sobre o entendimento das profundas mudanças geomórficas associadas ao levantamento de áreas de planícies costeiras, bem como, sobre a interpretação do registro arqueológico regional ao longo do litoral norte do estado de São Paulo. Tais estudos também foram de encontro com as perspectivas de controles geoarqueológicos e capeamento sedimentar de sítios em outras áreas da Costa Sul-Sudeste, como em Guaratuba (conforme item 5.1). Assim, a constatação da presença de pacotes sedimentares espessos ligados processos de descidas de massa e formação de leques aluvionares recentes em Caraguatatuba, possibilitou a indicação por parte do autor, da necessidade de implantação das medidas preventivas que se sucederam ao diagnóstico arqueológico. Em outro aspecto, permitiu visualizar as implicações desta pesquisa para analogias e inferência sobre situações similares encontradas em Guaratuba, visto que nesta ocorrem leques aluvionares presumivelmente de idade holocênica com potencial para o capeamento de 
sítios arqueológicos. Por fim, a pesquisa em Caraguatatuba constituiu uma investigação singular sobre os processos de recuperação de informações, das possibilidades de geração de "Não Informação" e das conseqüências interpretativas sobre a produção de conhecimento arqueológico neste setor da costa brasileira.

A área onde será instalada a UTGCA apresentou um contexto regional de aspectos ambientais, etno-históricos e arqueológicos extremamente favoráveis à ocorrência de vestígios materiais remanescentes de ocupações pré-coloniais e históricas. Entretanto, nos trabalhos de diagnóstico prévio (Scientia, 2006) não foram detectados quaisquer indícios de interesse arqueológico. Mesmo assim, por medida preventiva foi indicado um Programa de Prospecção Arqueológica Intensiva para a verificação detalhada da Área de Influência Direta (ADA) do empreendimento. Este programa seria implementado por meio de prospecções sistemáticas superficiais e subsuperficiais a fim de exaurir todas as possibilidades de ocorrerem bens arqueológicos sob risco de serem destruídos durante a execução das futuras obras.

Entretanto, ao averiguar a existência de novas informações geradas pelos estudos geológicos-geotécnicos da área, bem como, das medidas de engenharia tomadas para a implantação do empreendimento, o autor, em conjunto com o corpo-técnico-científico contratado para os trabalhos (Scientia, 2007) alertou de prontidão para as problemáticas arqueológicas surgidas em função desses novos condicionantes, a saber:

1) Uma documentação mais precisa sobre a espessura do pacote sedimentar advindo da catástrofe natural de 17 e 18 de março de 1967, ocorrida no município de Caraguatatuba, e que atingiu diferentes compartimentos ambientais, incluindo as encostas e sopés da Serra e Planície Costeira. O evento foi ocasionado por fatores interligados, dos quais pode-se destacar como fator deflagrador, o pronunciado volume de chuvas concentradas 41 , que propiciaram o desencadeamento de escorregamentos e processos de descidas de massa, incluindo corridas de detritos ('debris flows"), corridas de lama ("mud flows") e enchente com alta concentração de material sólido ("mud flood"). O IPT (Instituto de Pesquisas Tecnológicas do Estado de São Paulo), em estudo desenvolvido em Novembro de 2006 (após o diagnóstico arqueológico elaborado para o EIA do empreendimento) constatou que na área da futura UTGCA, os depósitos daquele evento apresentam espessuras que variavam entre médias de 1,6 e 1,8 metros no limite norte e, entre 2,1 a 2,2 no limite sul da área. No entanto, em outros pontos situados mais a montante (próximos a serra), tais camadas poderiam chegar a impressionantes 9 metros de espessura. Com o conhecimento

\footnotetext{
${ }^{41}$ Conforme Wolle, (1986 apud IPT, 2006:15) as chuva atingiram a marca de $586 \mathrm{~mm}$ em 48 horas o que representou cerca de $35 \%$ da pluviosidade anual da região.
} 
da projeção das iso-espessuras do pacote de sedimentos derivados das corridas de massa do evento de 1967 (Figura 22), constatou-se portanto, que as espessuras na área da UTGCA são, em geral, superiores àquelas atingidas pelas técnicas convencionais de prospecção arqueológica, criando, assim, um problema de incompatibilidade entre as técnicas utilizadas e sua eficácia frente aos objetivos da pesquisa (visto que só seria possível cobrir os depósitos recentes do evento).

2) Por outro lado, em função dos estudos geotécnicos e dos possíveis riscos de novas catástrofes ambientais na área da UTGCA, houve uma readaptação dos projetos de engenharia para as fundações da planta industrial. Esta nova mudança previu que, além da deposição de espessa camada de aterro sobre a atual planície fluvial, seriam utilizadas estacas de concreto cravadas de forma concentrada até o embasamento rochoso, atravessando pacotes sedimentares com até cerca de 30 metros de profundidade. Esta situação implicou no prognóstico de que as atividades técnicas de fundação poderiam afetar irreversivelmente potenciais camadas arqueológicas existentes em profundidades bem maiores que a do evento de 1967. 


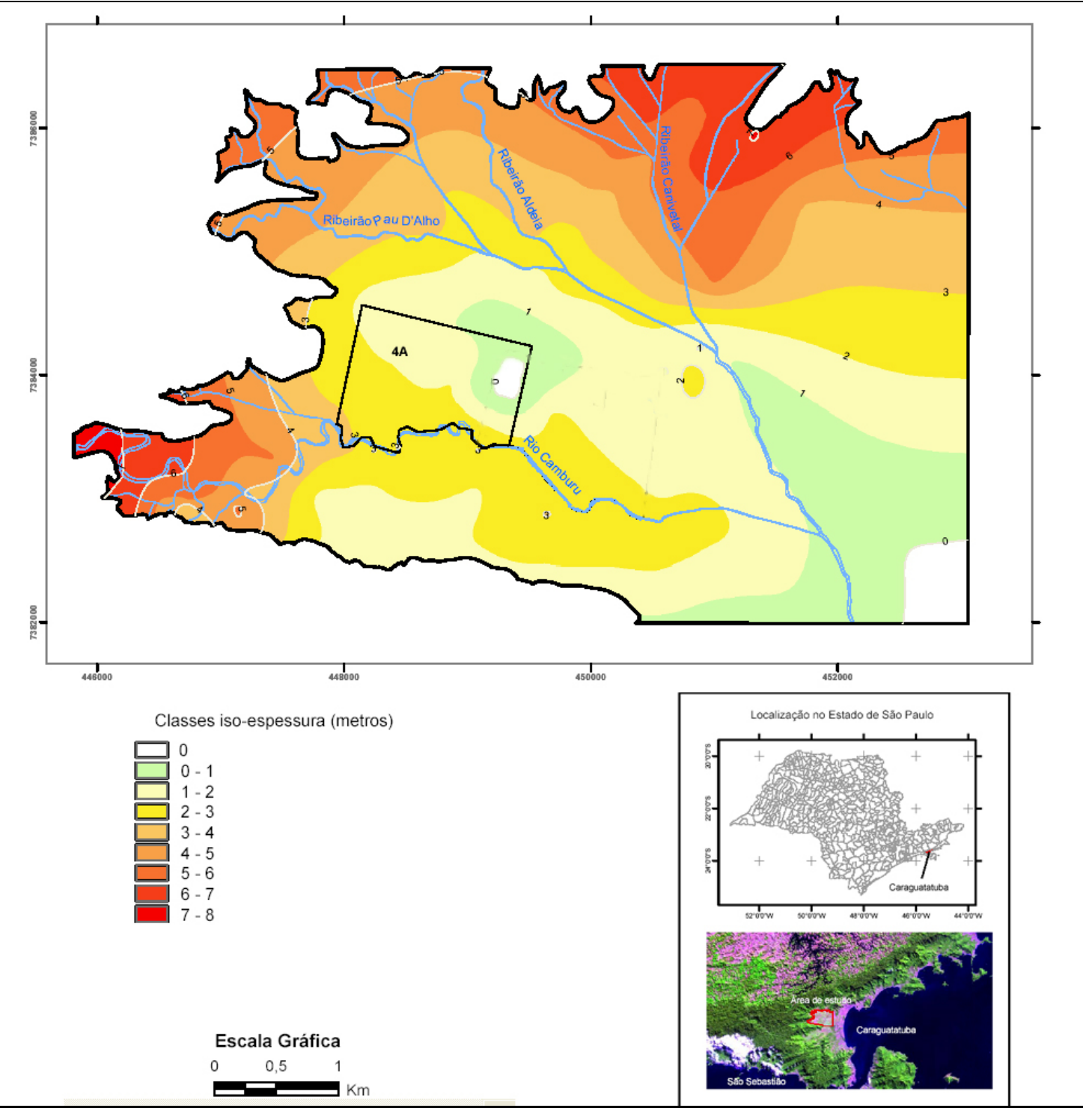

Figura 22: Mapa de Iso-espessura do depósito da corrida de detritos de 1967, na área da planície de Caraguatatuba, em local previsto para a instalação da UTGCA/Petrobrás (área 4A) (fonte: IPT, 2006, adaptado)

Cabe citar que a hipótese do segundo item levou em conta, não apenas as inferências anteriormente realizadas pelo autor sobre o potencial da ocorrência de sítios profundos em área costeiras (BROCHIER, 2001) mas também novas projeções e inferências tendo por base modelos morfoestratigráficos gerados para Costa Sul-Sudeste, mas principalmente, os perfis e datações de sedimentos argilo-orgânicos realizados por FÚLFARO et al. (1976), além dos modelos de evolução da formação da planície sedimentar de Caraguatatuba elaborados por Martin e Suguio (1978).

Quanto aos depósitos de subsuperfície, conforme FÚLFARO et al. (1976),

"a seqüência estratigráfica atravessada indica que, da base para o topo, há uma passagem de sedimentos francamente fluviais (vários ciclos) para sedimentos mistos de água salinas, com restos de conchas e fragmentos vegetais, sugerindo que a deposição ocorreu em um 
ambiente estuarino, (...) em direção ao topo, canais de maré instalados em zonas de planície de maré teriam sido substituídos por mangues, o que é evidenciado pela presença de argilas ricas em matéria orgânica e restos vegetais, além de turfas. Capeando a seção, ocorreriam barras arenosas representativas de antigas linhas-de-praia" (grifo nosso).

Informações importantes neste sentido referem-se a datações realizadas sobre conchas e madeiras que foram extraídas de sedimentos da Planície Costeira de Caraguatatuba (Quadro 4), que demonstram a existência de depósitos holocênicos sob grandes profundidades nessa área.

Os dados estratigráficos também apontam para a existência de cunhas de material clástico, atribuídas a escorregamentos de massa que ocorreram, conforme FÚLFARO et al. (1976), cinco vezes entre 8.000 e 3.300 anos A.P. A última ocorrência conhecida refere-se à catástrofe de 1967 em Caraguatatuba que, segundo CRUZ (1974), o fenômeno estaria ligado a processos climáticos, orográficos, fisiográficos e antrópicos, atuando em seus limiares.

Quadro 4: Dados relativos a datações de C14 na Planície Costeira de Caraguatatuba

\begin{tabular}{|c|c|c|c|}
\hline Amostra & Natureza & Posição do Antigo Nível (m) & $\begin{array}{l}\text { Idade em } \\
\text { Anos A.P. }\end{array}$ \\
\hline SP 05-2 & $\begin{array}{lcc}\text { Madeira } & \text { e } & \text { concha } \\
\text { (cota:15m/prof.:21m) } & \end{array}$ & $-16( \pm 1)$ & $8.030 \pm 150$ \\
\hline SP $05-1$ & 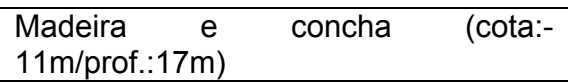 & $-12,5( \pm 1)$ & $8.950 \pm 220$ \\
\hline SP 02-2 & Madeira (cota:-15m/prof.:24,3m) & Depósitos continentais & $>35.000$ \\
\hline SP 02-1 & Madeira (cota: $+2,8 \mathrm{~m} /$ prof.: $6,5 \mathrm{~m}$ ) & Depósitos continentais & $3.320 \pm 100$ \\
\hline$A-300$ & Concha (1-2m de prof.) & Abaixo do atual (1-2m) & $6.745 \pm 170$ \\
\hline$A-302$ & Concha (1-2m de prof.) & Abaixo do atual (1-2m) & $6.725 \pm 170$ \\
\hline$A-290$ & $\begin{array}{lllll}\begin{array}{l}\text { Concha } \\
\text { praiais }) .\end{array} & \left(2^{\circ} \text { geração }\right. & \text { de } & \text { cristas } \\
\end{array}$ & Acima do atual (após $2^{\circ}$ máx. transgr.) & $2.565 \pm 90$ \\
\hline A - 291 & Concha superficie & Acima do atual & $640 \pm 80$ \\
\hline
\end{tabular}

Fonte: SOUZA, 1990, citando outros autores.

Por sua vez, Martin e Suguio (1978), apresentam os tipos de formações quaternárias de origem marinha e lagunar e um perfil morfoestratigráfico (Figura 23 ), modificado de Fulfaro et al .(op cit), tendo por base o resultado das sondagens e as datações radiométricas . Sugerem então um modelo de estágios evolutivos para explicar a origem da planície costeira. Neste modelo podemos destacar a incidência de depósitos lagunares interiorizados formados tanto após o máximo da transgressão Cananéia (120 ma), quanto após o máximo da transgressão Santos (5.100 anos AP). Em ambas, o mecanismo de formação desses depósitos argilo-orgânico e argilo-arenosos foi à presença de ilha-barreiras interiorizadas que, em conjunto com aspectos topográficos do substrato, isolaram zonas lagunares. Para o caso dos sistemas lagunares holocênicos, dois fragmentos de madeira coletados a partir de 
antigos depósitos de manguezais, atestariam segundo os autores, a presença de antigos níveis marinhos em - 12,5 $\pm 1 \mathrm{~m}$ e $-16 \pm 1 \mathrm{~m}$. Se esta interpretação estiver correta não apenas existiria a possibilidade da detecção de sítios sob os depósitos de 1967, mas sítios sobre antigas superfícies próximas a zonas lagunares, em datas de aproximadamente 8.000 anos (conforme curva proposta por CORREA, 1996)

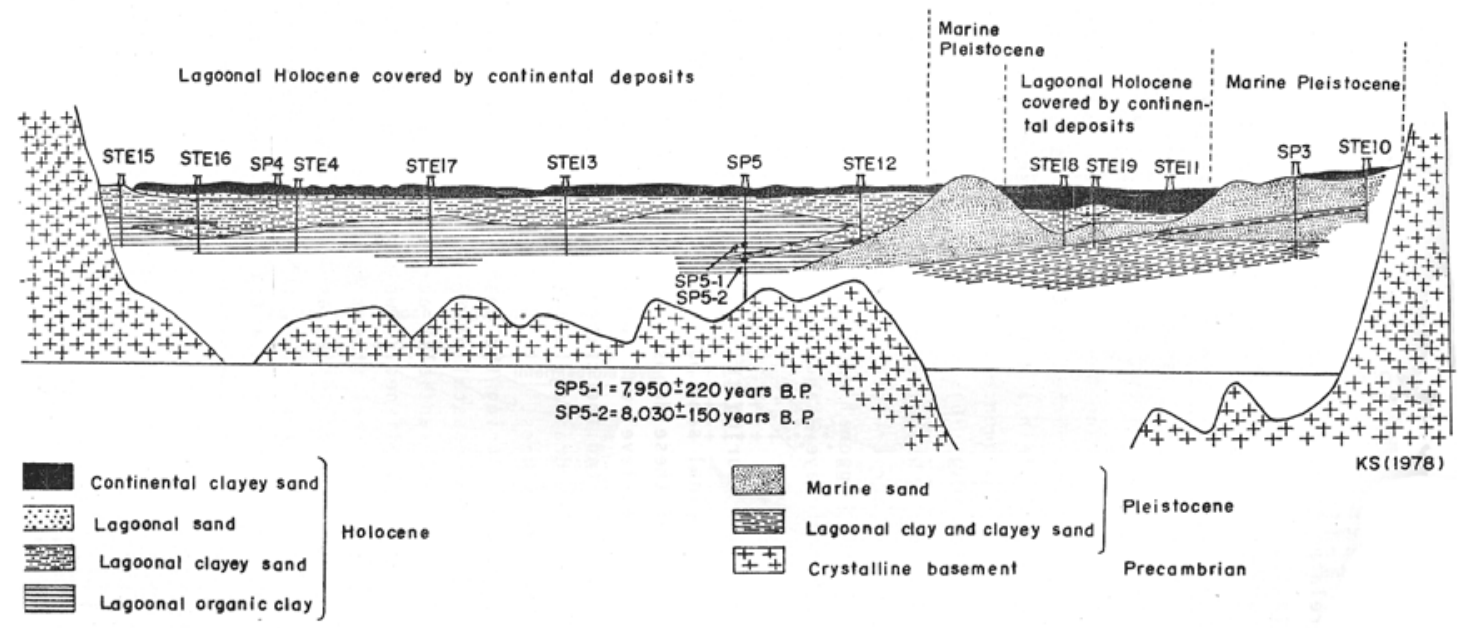

Figura 23: Modelo de perfil morfoestratigráfico elaborado por MARTIN; SUGUIO (1978), tendo por base aquele produzido por FÚLFARO et al. (1976)

Diante da situação exposta, houve por bem empreender as atividades prospectivas intensivas inicialmente previstas ${ }^{42}$, visto existirem áreas que não foram atingidas pelo evento de 1967 (como um morrote situado no extremo leste-nordeste da área) e; a possibilidade de ocorrerem variações na projeção de iso-espessuras, devido a diferenças de escala e objetivos entre os levantamentos geológicos e arqueológicos. Por sua vez, esses estudos estiveram focados também na verificação de elementos que permitissem visualizar alternativas e propostas capazes de atender as novas demandas surgidas (SCIENTIA, 2007).

\footnotetext{
${ }^{42}$ Medidas tomadas em reunião ocorrida na $9^{a} \mathrm{SR} / \mathrm{IPHAN} / \mathrm{SP}$, onde concluiu-se pela necessidade do prosseguimento das pesquisas já aprovadas pelo órgão, atentando desta vez, para avaliações mais pormenorizadas de campo, as quais pudessem resultar em recomendações adicionais a serem implementadas como condicionantes às licenças ambientais subseqüentes.
} 
Com os resultados das sondagens sistemáticas executadas na área da planície sedimentar, constatou-se que existem inúmeras evidências que comprovam as projeções feitas pelo IPT existindo, no entanto, uma variação importante. Esta se refere à ocorrência de área suavemente mais elevada (Figura 24, indicado como "aterro"), a cerca de 200 metros a sudoeste da base do morrote, no interior da área útil da UTGCA (planta industrial). No mapa de Iso-espessura do depósito de 1967 (Figura 22), este local está disposto quase que integralmente na projeção de 1-2 metros.

Ao findar dos trabalhos de prospecção arqueológica intensiva registraram-se, entre outros, a detecção de uma área possivelmente não afetada pelo evento de 1967, disposta no setor central da área da UTGCA, com limites à cerca de 200 metros a sudoeste da base do morrote, apresentando zonas de entorno favoráveis à detecção de vestígios (com áreas denominadas de faixas "a" e "b).

Com base nos resultados apresentados, e das novas circunstâncias constatadas, foi proposto a implantação de um Programa de Prospecções Arqueológicas Profundas, capaz não apenas de atravessar a camada de 1967, mas, também, prospectar estratos significativos dos sedimentos profundos subjacentes, e que serão atingidos pelo estaqueamento das fundações da UTGCA.

A locação das sondagens profundas apresentadas, compõem-se proposta estratificada com zonas determinadas pelo potencial arqueológico e variação nas profundidades de furos (Figura 24). Esta última compôs a versão final apresentada ao IPHAN (Scientia, 2007), tendo por justificativa a possibilidade da inclusão de novos critérios de avaliações e da determinação dos pontos a serem perfurados, da malha a ser escolhida e, da metragem total a ser realizada. 


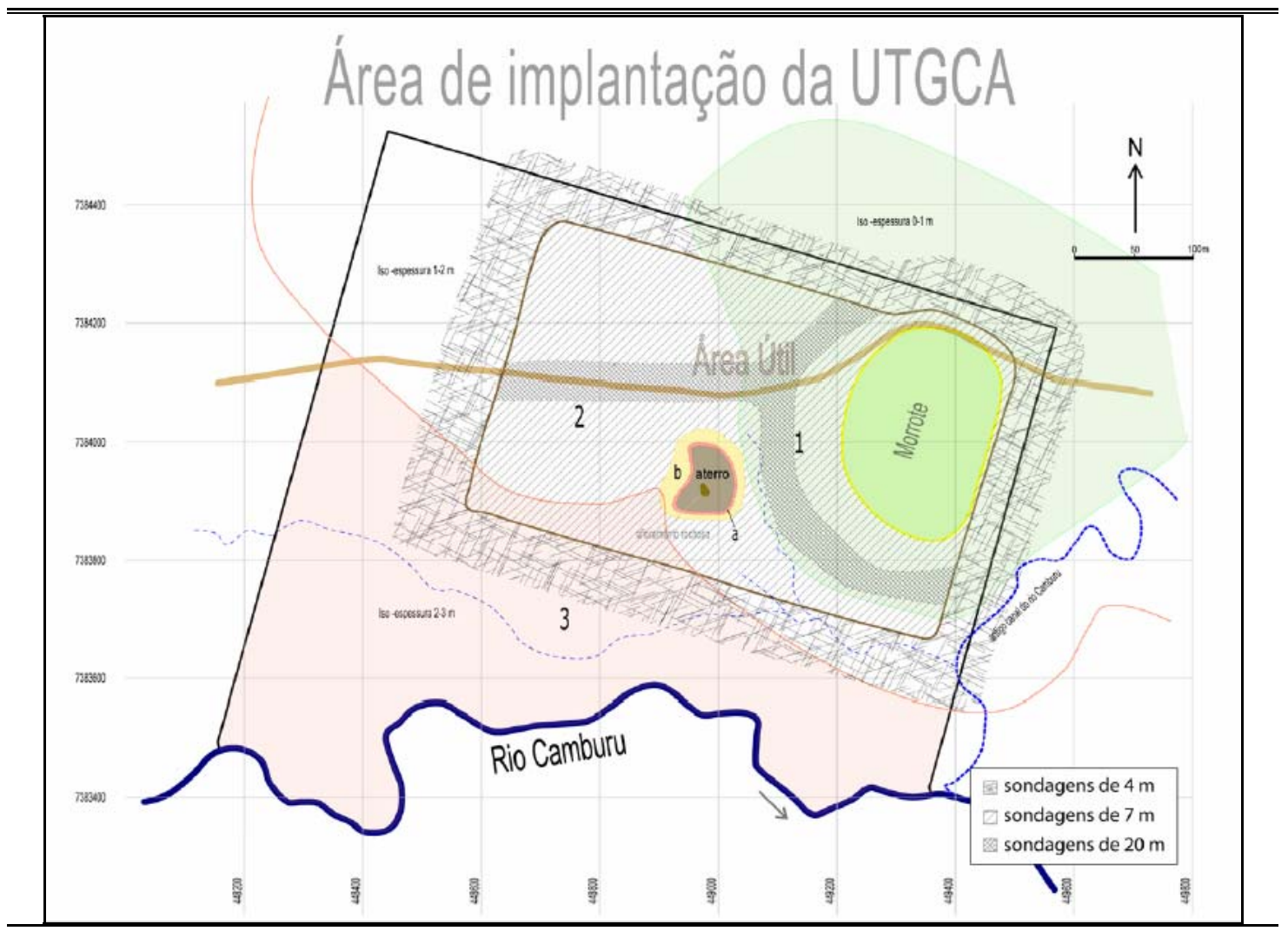

Figura 24: Proposta de prospecção subsuperficial. Sondagens de $4 \mathrm{~m}$ de profundidade (faixa de entorno); sondagens de $7 \mathrm{~m}$ de distribuídas na área útil (com atenção para as faixas "a" e "b" de entorno do aterro); e as sondagens de $20 \mathrm{~m}$ de profundidade (faixa mais escura). (Fonte: Scientia, 2007)

Quanto ao método de perfuração, as sondagens executadas pela EMAGE/LENC seguiu procedimentos similares àqueles utilizados em coleta de amostras de solos, conforme norma NBR 13895 - Construção de Poços de Monitoramento e Amostragem, e Procedimento de Amostragem de Águas Subterrâneas da CETESB (POP-EQSS). No entanto, devido as especificadas do estudo em questão, houveram pequenas variações na logística e nas manobras técnicas de retirada e controle dos testemunhos para as análises arqueológicas.

A sondagem rotativa consiste num sistema de perfuração moto mecanizado que age através de forças de penetração e rotação conjugadas para avanço em materiais de diferentes resistências mecânicas. As sondagens na área foram realizadas com diâmetro nominal øHW (furo com 99,23mm de diâmetro e testemunho com 76,20mm de diâmetro) (Foto 1). Também foram utilizadas as camisas de aço como amostradores, sendo neste caso retirados testemunhos de cerca de $100 \mathrm{~mm}$ de diâmetro (Foto 2). A amostragem foi feita por meio de barrilete-amostrador simples øHWG de forma contínua sem a presença de água. Os avanços serão feitos por meio de cravação roto-percussiva dos revestimentos até que se atinja a próxima cota de amostragem. A partir daí o processo se repete até o final do furo. A capacidade recuperação dos testemunhos variou dependendo das características geotécnicas, estratigráficas e litológicas dos substratos perfurados. Em geral as camadas 
argilosas e argilo-arenosas foram recuperadas integralmente. No entanto, para camadas arenosas, areno-granulosas ou mesmo areno-argilosas, a recuperação variou entre parcial e perda total.

Os testemunhos retirados do barrilete-amostrador foram acondicionados em tubo receptor plástico, bipartido, cujos segmentos (Fotos 3 e 4) foram utilizados para o transporte à bancada de corte (Foto 5), no registro lito-estratigráfico, nas analises arqueológicas e coletas de amostras in loco (Foto 6).

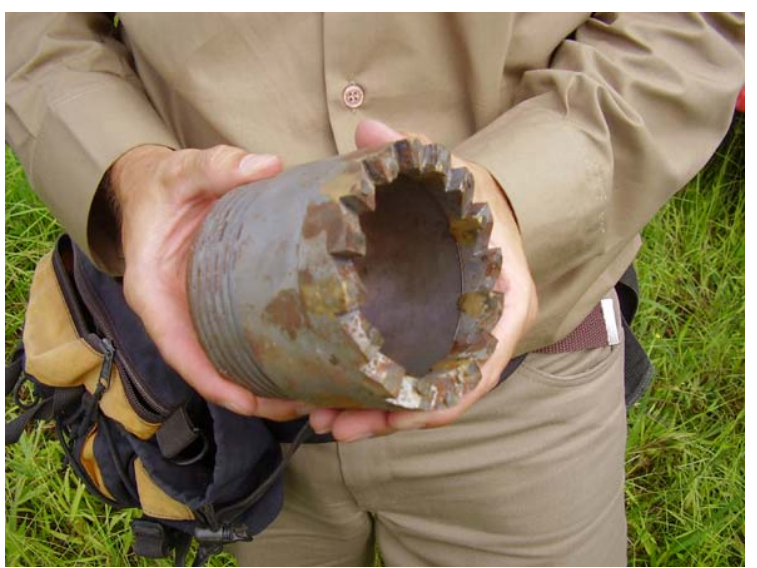

Foto 1 - Diâmetro da broca de perfuração do barrilete-amostrador.

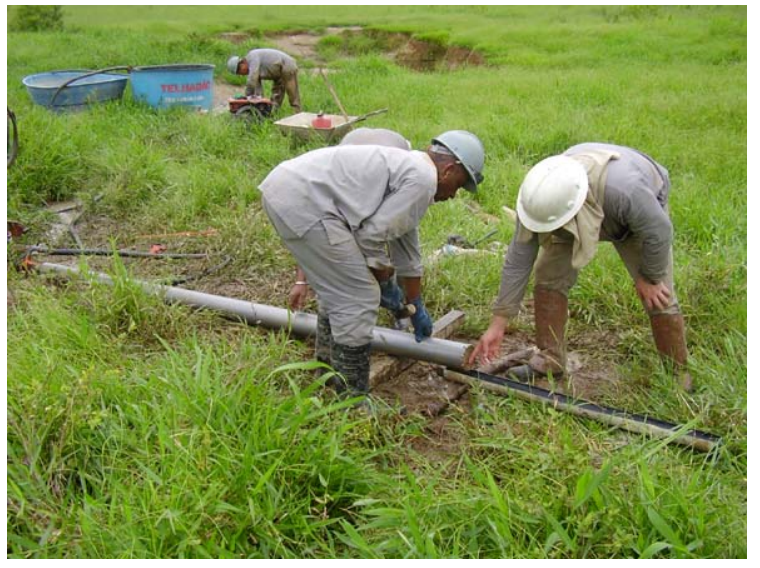

Foto 3 - Processo de retirada dos testemunhos, que são depositados sobre segmentos bipartidos de tubos de pvc rígido.

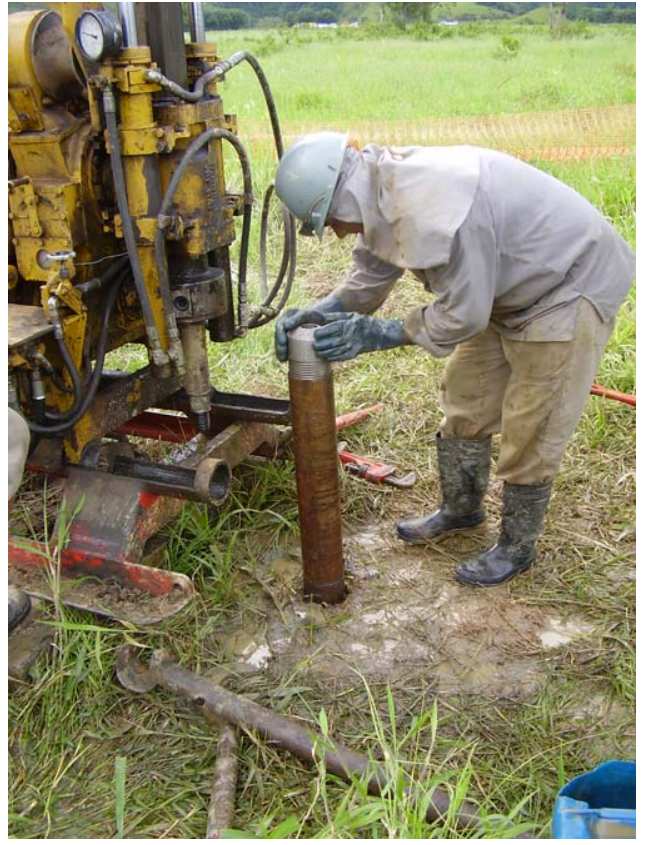

Foto 2 - Retirada de testemunhos de maior diâmetro $( \pm 100 \mathrm{~mm})$, com o uso de tubo utilizado para encamisar os furos.

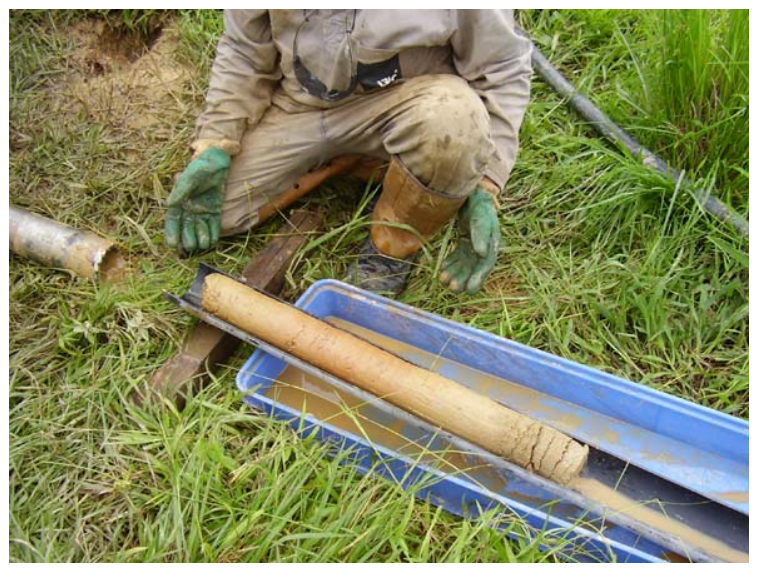

Foto 4 - Aspecto dos testemunhos de sondagem após acondicionamento em segmento de tubo de pvc rígido. 


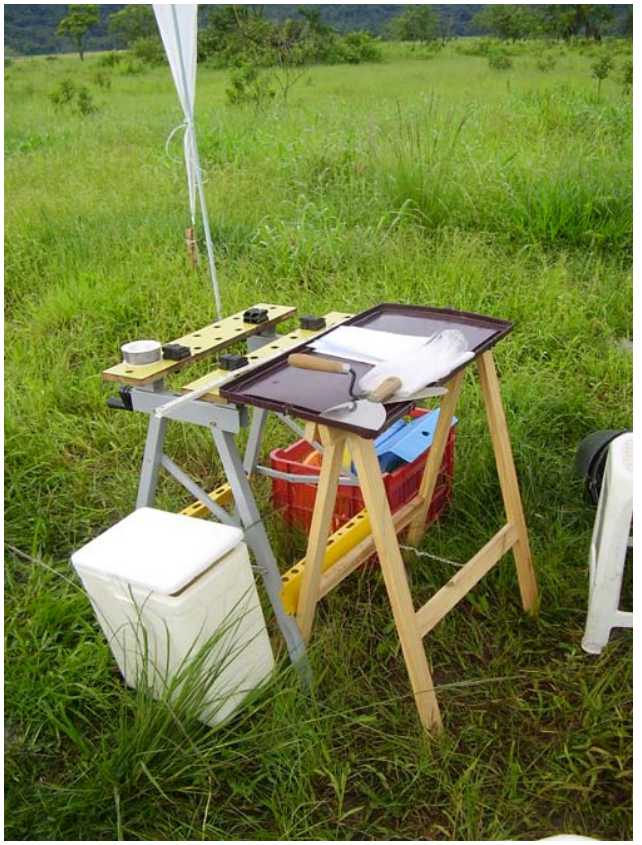

Foto 5- Bancada de corte, registro e coleta de amostras, utilizada nas analises arqueológicas dos testemunhos profundos.

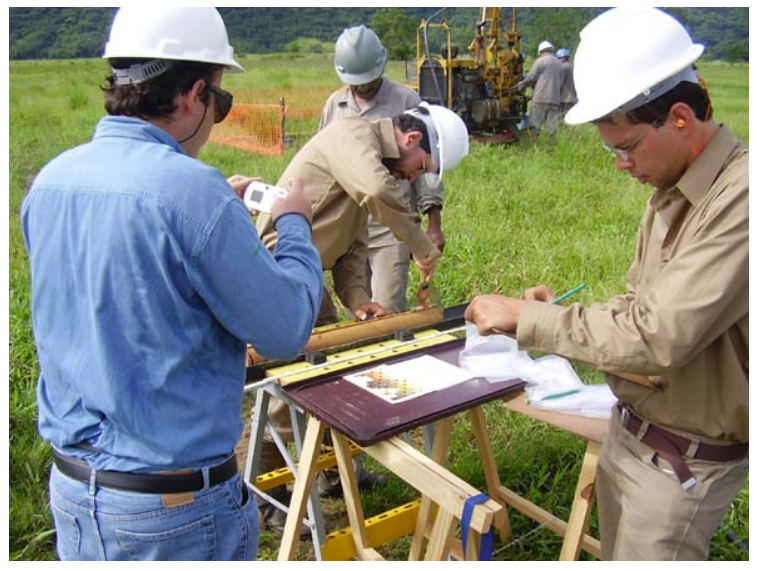

Foto 6 - Registro das atividades arqueológicas desenvolvidas sobre os testemunhos retirados das sondagens (visita técnica de engenheiro da Petrobrás).

Quanto às conclusões preliminares dos trabalhos realizados nesta etapa do Programa de Prospecção Arqueológica Profunda na área da UTGCA, os primeiros resultados obtidos vão de encontro às expectativas e decisões tomadas no decorrer das pesquisas de campo. Assim, embora sejam necessárias as avaliações laboratoriais voltadas para a detecção de micro-artefatos nas amostras recolhidas, já existem elementos de identificação de uma área de interesse arqueológico na área da UTGCA. O local foi detectado por uma das novas sondagens estabelecidas a partir do critério de "zonas estratificadas potenciais", denominada FXc-01. Esta sondagem foi realizada na lateral norte da pequena elevação central sob as coordenadas UTM (Sad 69) 23K 449000 / 7384050, cujo terreno está em cota aproximada de 7,40 m. O material arqueológico ocorreu no testemunho recuperado entre as profundidades de 2,10 e 3,25 metros (Fotos 7), sendo posteriormente confirmado entre cerca de 2,60 a 2,80 metros de profundidade. A primeira ocorrência, constituída por lasca descortiçada em diabásio/basalto (Foto 8), foi detectada no limite entre camada areno-argilosa de coloração cinza, levemente variegada e uma camada argilosa a argiloarenosa, de coloração predominantemente marrom-amarelo, variegada com manchas cinzas. Na camada inferior verificou-se ainda, a presença de restos vegetais carbonificados. Aparentemente, o material estaria disposto sobre colúvio, nas proximidades de antigos afloramentos rochosos, atualmente soterrados.

Posteriormente, no mesmo nível de detecção, foi possível perceber a existência de nova lasca, desta vez produzida em sílex (Foto 9). Com a vistoria cuidadosa dos níveis de 
ocorrência foi possível identificar outras 4 evidências em diabásio e quartzo hialino, também formadas por lascas descorticadas e possivelmente produzidas por percussão direta (Foto 10). Estas estavam distribuídas por cerca de $20 \mathrm{~cm}$ ao longo do perfil. Pelo número de lascas detectadas em um só furo de sondagem, estima-se que o mesmo tenha atravessado um sítio arqueológico de importante relevância científica. Considerando a descoberta dos macro-vestígios, todo o testemunho foi segmento em parcelas de $15 \mathrm{~cm}$, para ser recolhido como amostras para análise de micro-artefatos (Foto 11). Antes da coleta, no entanto, todo o sedimento foi verificado manualmente a fim de detectar novas ocorrências (Foto 12).
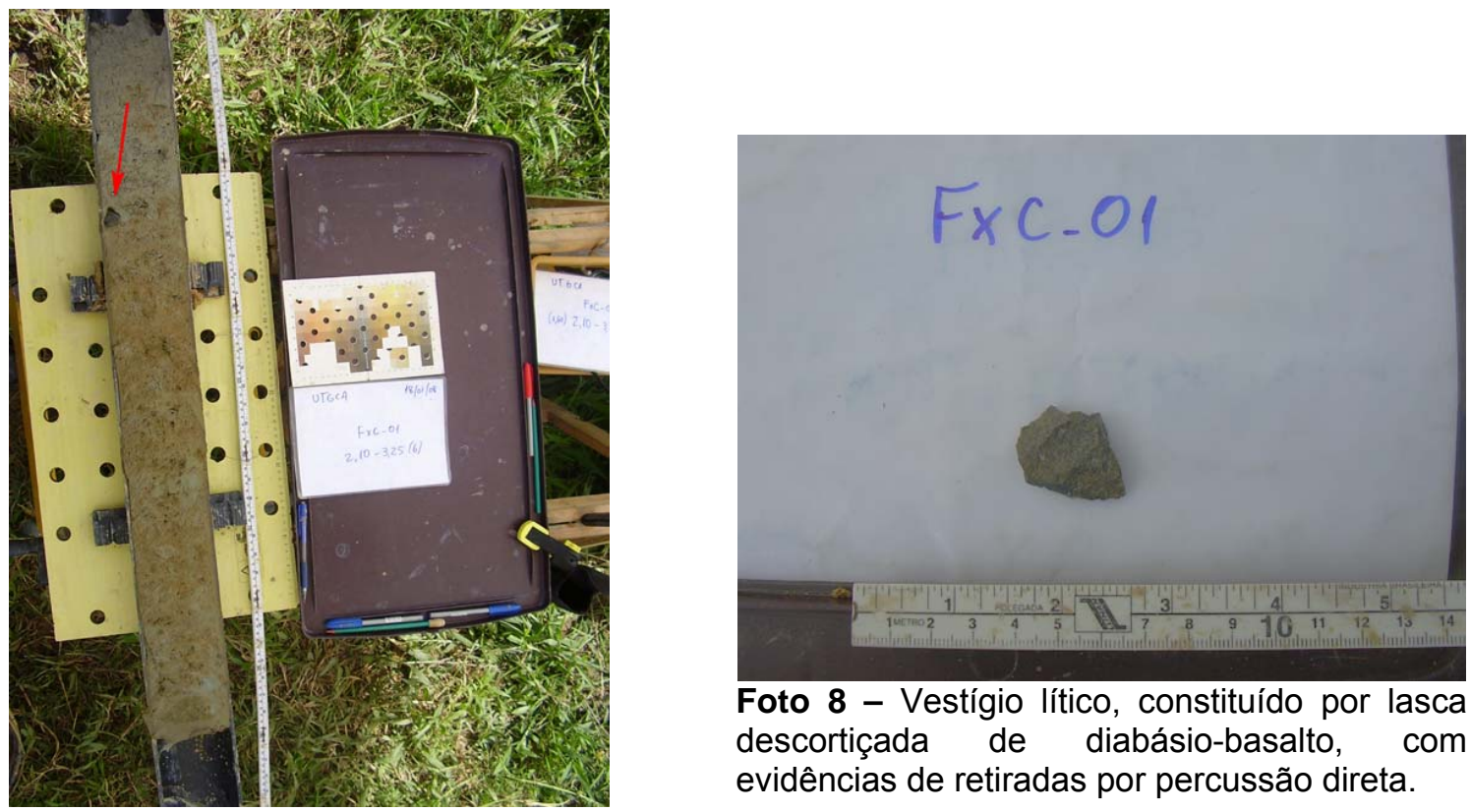

Foto 8 - Vestígio lítico, constituído por lasca descortiçada de diabásio-basalto, com evidências de retiradas por percussão direta.

Foto 7 - Testemunho da sondagem FXc-01 entre as profunidades 2,10 e 3,25 metros, com ocorrência do primeiro vestígio lítico.
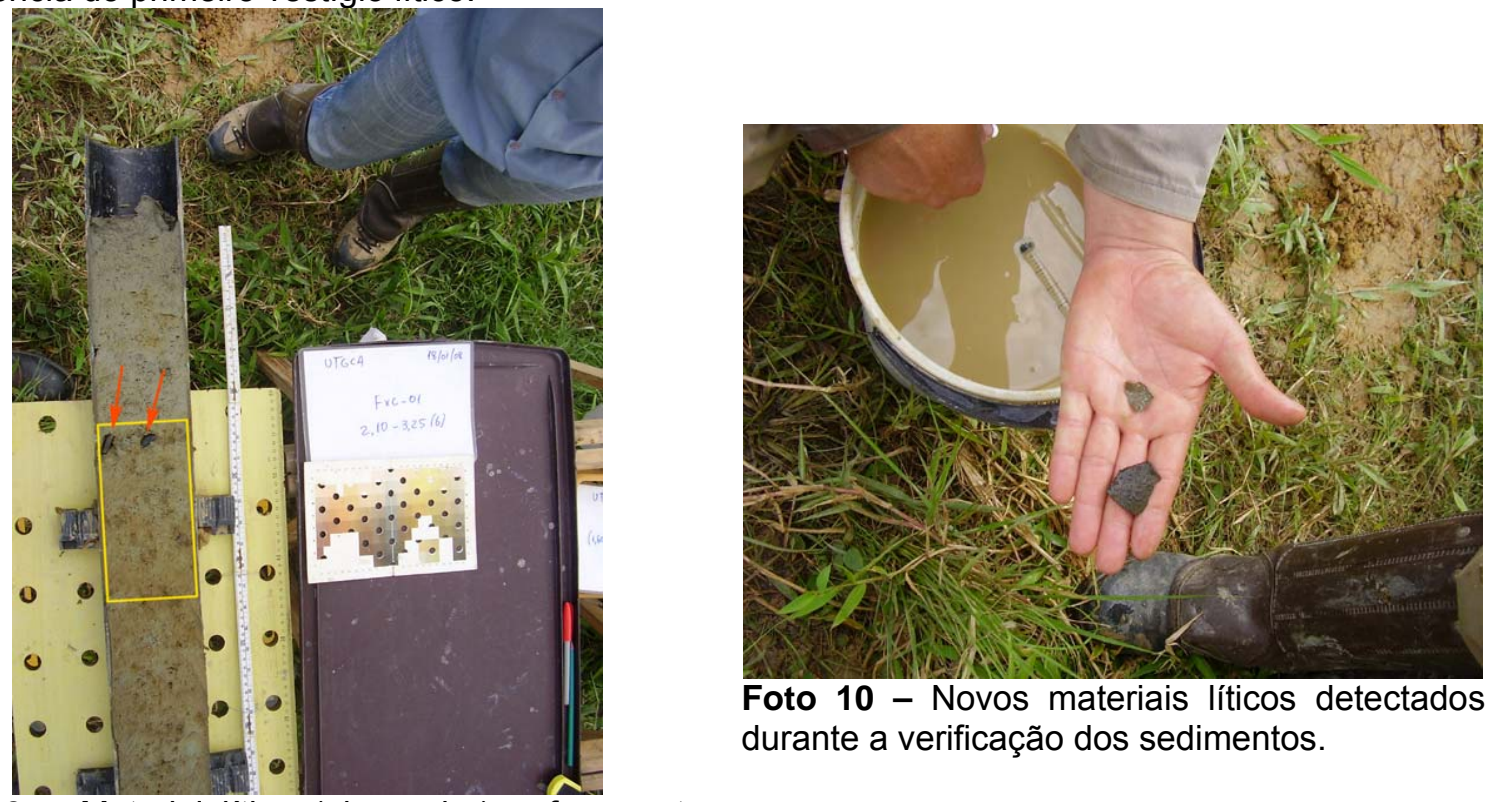

Foto 10 - Novos materiais líticos detectados durante a verificação dos sedimentos.

Foto 9 - Material lítico (abrasador) e fragmento cerâmico recolhidos nas atividade de retificação. 


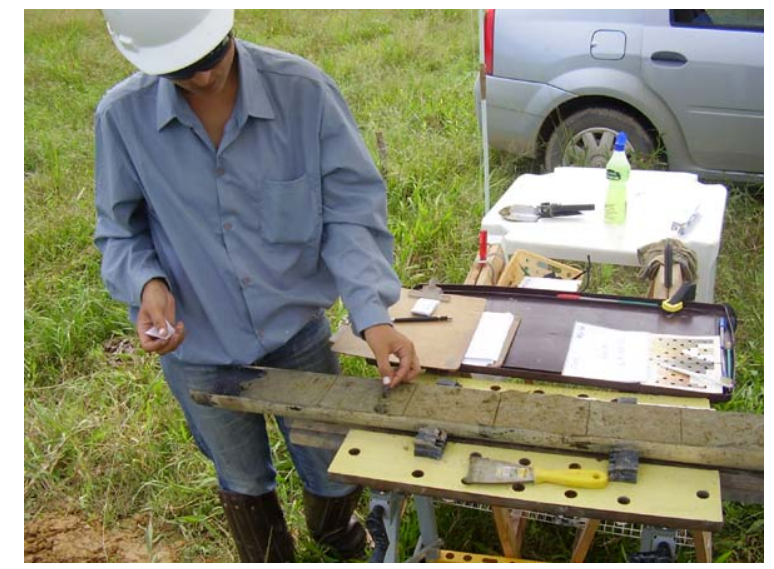

Foto 11- Segmentação do testemunho para coleta de amostras para micro-artefatos.

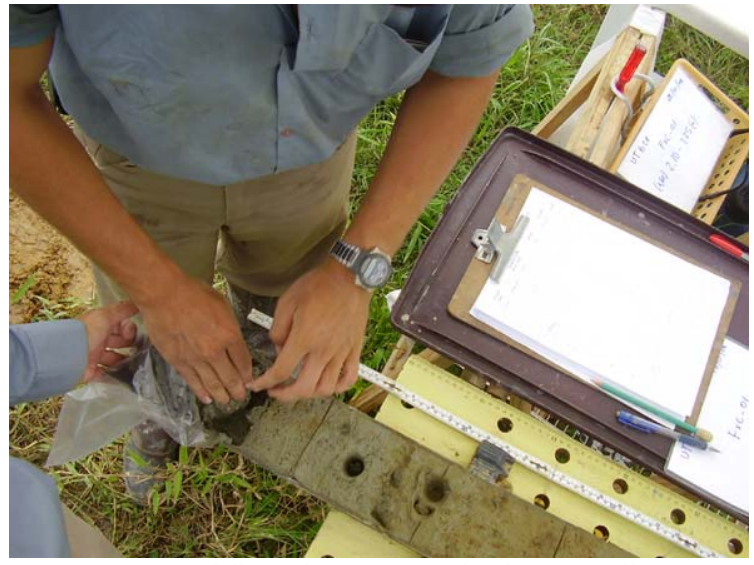

Foto 12 - Vistoria manual dos sedimentos antes da coleta, à procura de novas evidências.

A fim de confirmar o nível arqueológico, foi realizada nova sondagem rotativa e 5 tradagens com profundidades de até 4 metros. Em três delas foi obtido lascas alteradas de sílex, ou siltito silicificado, posicionadas no nível médio de 2,70 metros de profundidade. A execução das tradagens, no entanto, foi dificultada pela presença de lençol freático elevado (cerca de 1,5 metros) e ocorrência de camadas arenosas. Neste sentido foi utilizado também um amostrador tipo Shelby para recuperação de amostras arenosas logo abaixo do lençol freático. Neste caso, a avaliações foram feitas sobre a bancada de corte e registro. Finalmente, considerando a disposição pontos de identificação e o estabelecimento de zona de entorno de segurança, a área de ocorrência foi delimitada provisoriamente, procedendo o cercamento e isolamento do terreno em questão). O cercado realizado apresentou dimensões aproximadas de $25 \times 35$ metros.

Ao considerar a densidade relativa de lascas descortiçadas; a extensão preliminar de ocorrência; a diversidade litológica e; a presença de elementos inconteste de ação humana na produção dos vestígios detectados, infere-se a presença de sítio arqueológico lítico na área em questão. Esta caracterização implica no estabelecimento de medidas preventivas e mitigadoras cabíveis, visto o patrimônio arqueológico estar protegido pela Lei Federal $3924 / 1961$.

Deste modo, tendo atingido os objetivos indicados no Programa de Prospecção Arqueológica Profunda da UTGCA, o presente estudo permitiu o levantamento e prospecção das zonas consideradas de maior potencialidade arqueológica, a verificação in loco de macro-vestigios e a coleta de amostras para as análises de micro vestígios em laboratório. Por sua vez, permitiu a identificação de importante testemunho da cultura material disposto em profundidade próxima a 3 metros, indicando a existência de parcelas subsuperficiais capazes de conservar registros arqueológicos na área em questão. 


\section{A MODELAGEM DA INFORMAÇÃO E INCERTEZA NA GERAÇÃO DE UM MODELO DE FAVORABILIDADE DE SÍTIOS PROFUNDOS NA PLANÍCIE COSTEIRA DE GUARATUBA.}

Com base nos pressupostos e modelos morfoestratigráficos apresentados no capitulo anterior, bem como, nas informações advindas nos estudos realizados em Guaratuba e Caraguatatuba, foi elaborado um modelo conceitual diagramático que permite visualizar as principais inferências sobre o potencial de preservação e capeamento sedimentar de sítios arqueológicos na área de planície costeira e sistema estuarino de Guaratuba (Figura 25). A elaboração deste modelo, chamado aqui de "modelo de trapeamento de sítios" ainda que sujeito a inúmeras incertezas, é um passo fundamental no processo de seleção das informações e na escolha de um universo variável porém limitado de indicadores capazes de produzir conhecimento sobre o evento esperado. Certamente poderão existir variáveis não computadas, seja a favor ou contra a hipótese de preservação. Neste sentido, a noção de controles geoarqueológicos é válida, pois almeja a explicitação máxima dos condicionantes considerados, a possibilidade de inclusão da incerteza no modelo e, principalmente, condições de tratamento das informações processadas. Ou seja, através de métodos derivados das ciências da informação, pretende-se avaliar o grau de certeza e incerteza das variáveis escolhidas, por meio de situações envolvendo probabilidades condicionais (em função de eventos já conhecidos) e da inclusão e manipulação de novas variáveis de modo a verificar a validade do modelo para diferentes situações apresentadas (neste caso também é possível variar a escala das análises, mas que não será utilizado nesta proposição). Por fim, tais métodos irão propiciar a modelagem preditiva de áreas favoráveis capazes de serem testadas empiricamente, seja para determinar sua validade, condições de precisão e exatidão, ou ainda, para o levantamento de novos dados/informações visando o aprimoramento do modelo.

Quanto ao modelo de trapeamento de sítios, este foi elaborado visando o entendimento da ocupação de pescadores-coletores na baia de Guaratuba, mas que no entanto, também pode ser utilizado na perspectiva de identificação de sítios caçadores-coletores nessas áreas.

Apesar de apresentar relações e limites entre ambientes de forma simplificada, uma das vantagens está na adaptação de diferentes informações advindas de diferentes fontes, mas que convergem em situações favoráveis. Quanto as informações de origem geológica, foram utlizados o modelo morfoestratigráficos de LESSA et al (2000), e, VILLWOCK( 1994) para a área das barreiras. Nas áreas disposta a retaguarda dos terraços pleistocênicos compreendeu adaptações dos modelos elaborados por Martin e Suguio (1978), para a 
planície costeira de Caraguatatuba. Por sua vez, os levantamento batimétricos e de depósitos sedimentares encontrado no fundo da baia de Paranaguá e baia de Antonina foram utilizados para a visualização dos possíveis depósitos existentes no fundo da atual baia de Guaratuba.

Quanto aos modelos de preservação e capeamento sedimentar de sítios foram feitas adaptações dos modelo de Waters (1992) e Kraft et al (1983), ambos relacionados a situações de submersão No entanto. o de Waters foca mais na possibilidade de sítios associados a paelo-vales e canais, por isso, foi posicionado nas áreas adjacentes a serra. Quanto ao de Kraft e outros, é mais abrangente e foca principalmente sobre os diferentes ambientes paleoesturinos. Finalmente, quanto à possibilidade de capeamento por depósitos de leques holocênicos, são utilizados os dados verificados em Caraguatatuba, bem como as datações holocênicas fornecidas por Bessa (1997) para leques dispostos no litoral paranaense.

No modelo são apresentados a posição de sítios na atual superfície e sua correspondência com antigas superfícies, sendo aventadas as hipóteses de preservação ou destruição (incluindo neste a remobilização). Cinco são as situações favoráveis segundo este modelo: 


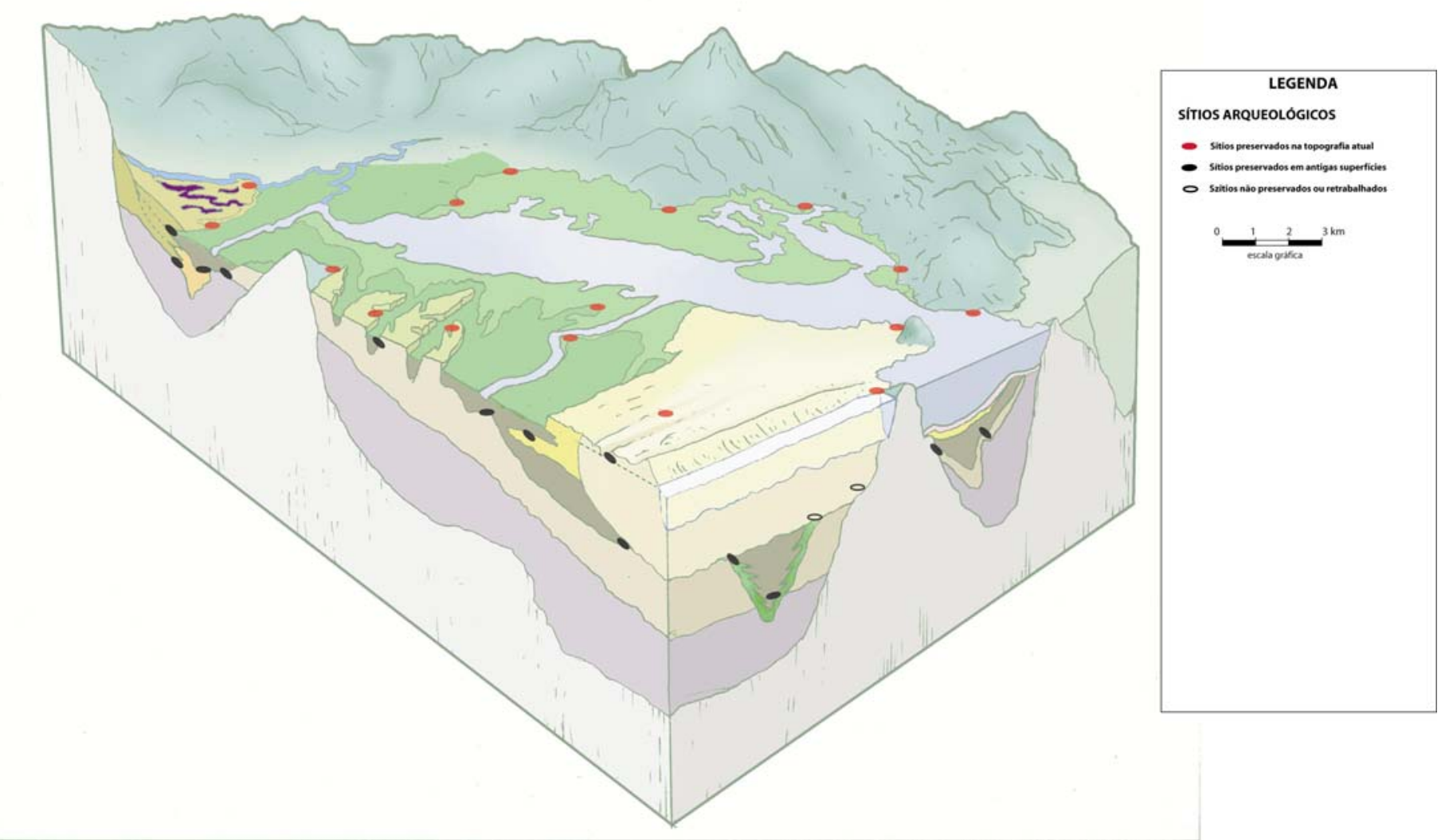

Figura 25:Modelo em forma de bloco diagrama indicando as diferentes situações estimadas para a localização de sítios encobertos na Baía de Guaratuba 


\subsection{A aPLICAÇÃo do RACIOCínIo PROBABILISTICO BAYESIANO NA GERAÇÃo de UM MODELO DE FAVORABILIDADE DE SítIOS ENCOBERTOS NA PLANÍCIE COSTEIRA DE GUARATUBA.}

Como visto no cap. 2, uma das característica do modelo Bayseano é a sua capacidade de lidar com um elevado conjunto de informações que constituem evidências ou inferências em favor de uma determinada proposição, hipótese ou evento. Como se verá adiante, regra de probabilidade condicional, poderá ser usada tanto para a determinação de um modelo explicativo (ou de diagnóstico) indicando valores de pesos para as variáveis estudadas, quanto para aplicação de um modelo preditivo, onde o conjunto de probabilidades condicionais podem ser utilizada para a avaliação de potencial e determinação de alvos.

\subsubsection{Pressupostos e descrição do Método}

A análise de tratamento da incerteza e a aplicação de modelos de raciocínio em sistemas baseados em conhecimento seguem neste tópico, os métodos propostos por Soares et al (2002) que aplicou o modelo probabilístico bayesiano na geração de mapas favorabilidade e suscetibilidade de eventos, que naquele caso focou a projeção de valores de probabilidade para o risco de escorregamentos na região de Campo Largo/PR (Soares;Soares; Fiori, 2002). Por sua vez, esses autores utilizaram a metodologia descrita por Agterberg (1989) e Rostirolla et al. (1998), acrescida de uma variação alternativa no modelo analítico-preditivo (Soares 2001b) inserindo a avaliação das incertezas associada ao mapeamento de indicadores (variáveis, evidências) favoráveis para a ocorrência do evento.

Neste sentido, a favorabilidade constitui:

uma avaliação quantitativa de expectativa da ocorrência deste evento, dada a presença ou ausência de uma série de indicadores a ele associados. A avaliação probabilística desta favorabilidade estima a probabilidade condicional de ocorrer relativamente à de não ocorrer o evento no domínio da variável e fora deste. Em seguida, o mesmo é feito com as outras variáveis. As sucessivas probabilidades condicionais são combinadas, de forma a estabelecer um escore final de probabilidade (Soares, 2000 inédito) de ocorrer o evento e de probabilidade de não ocorrer (Soares et al, op cit. p.62).

Assim, este tipo de análise pressupõe que a ocorrência dos eventos em questão, não apresenta causas únicas e determinativas, mas sim depende do resultado de uma combinação favorável de condições muitas das quais nem sempre estão acessíveis à 
investigação direta. Como proposta alternativa, é possível indicar as variáveis que apresentam relações ou expectativas de dependência com essas condições, e que a acumulação dessas observações e evidências (seja de forma explícita ou implícita) é que poderá revelar uma relação mais forte com a ocorrência do evento.

Por sua vez, como visto no item 2.3.1 diferentes fontes de incerteza, imprecisão e incompletude estão agregadas tanto à descrição de fatos observacionais como nos conceitos, e que argumentos voltados ao diagnóstico ou a determinação de uma proposição ou outra, não são inequívocos ou não ambíguos. Torna-se necessário abrir espaço para considerar ao menos, três tipos de incerteza: 1) aquela associada à evidência (E); 2) associada à proposição/inferência $(P) ; 3)$ associada à relação entre evidência e proposição (se E então P) (Soares; Perdoncini, 1999, p. 86).

Assim, tendo em conta o caráter cumulativo das evidências e a inserção da incerteza nos três domínios acima, torna-se possível a utilização de uma abordagem probabilística por meio do teorema de Bayes (probabilidade condicional) onde,

(...) calcula-se quanto uma evidência presente modifica a probabilidade original de ocorrência dos eventos relativamente à condição da evidência ausente. De forma homóloga, estas relações foram utilizadas para avaliar a probabilidade condicional nos espaços em que a presença da evidência ou do evento é incerta ou inexistente (Soares, op cit., p.59).

Seguindo o raciocínio de Soares (op cit, p. 62), pela regra de Bayes a ocorrência de um indicador $E$, altera a probabilidade prévia de ocorrer um evento $H$, num espaço $X$, por um fator igual à probabilidade da existência de $E$ dada à ocorrência do evento:

$P(H / E)=p(H) \cdot p(E / H)$

onde $p(E / H)$ é o fator modificador da probabilidade do evento $p(H)$

Entretanto, neste mesmo espaço de probabilidade, concorrem " $\mathrm{p}(\mathrm{H})$ ", " $\mathrm{p}(\mathrm{nH})$ " (inexistência de $\mathrm{H}$ ) e " $\mathrm{p}(\mathrm{iH})$ " (incerteza de $\mathrm{H}$ ) e sua soma é 1. De forma homóloga, temos:

$\mathrm{P}(\mathrm{nH} / \mathrm{E})=p(\mathrm{nH}) \cdot \mathrm{p}(\mathrm{E} / \mathrm{nH})$

$P(i H / E)=p(H) \cdot p(E / i H)$

A razão das probabilidades e seus espaços complementares constitui a Chance (Ch) de ocorrência do tipo de condição estabelecida. Nestes termos:

$C h(H / E)=[p(H) / 1-p(H))] \cdot[p(E / H) /(1-p(E / H))$ 


$$
\begin{aligned}
& \mathrm{Ch}(\mathrm{nH} / \mathrm{E})=[\mathrm{p}(\mathrm{nH}) / 1-p(n \mathrm{H}))] \cdot[\mathrm{p}(\mathrm{E} / \mathrm{nH}) /(1-p(E / H)) \\
& \mathrm{Ch}(\mathrm{iH} / \mathrm{E})=[\mathrm{p}(\mathrm{iH}) / 1-p(\mathrm{iH}))] \cdot[\mathrm{p}(\mathrm{E} / \mathrm{iH}) /(1-p(E / \mathrm{iH}))
\end{aligned}
$$

Por sua vez, com relação a $E$, as mesmas 6 relações podem ser estabelecidas para o domínio da não ocorrência de $E$ ("nE") e de E incerto ("iE"). Assim,

Os dois fatores do segundo membro, a chance prévia e o fator modificador, de cada relação, podem ser obtidos pelo conjunto de observações, de tal forma que as chances do evento podem ser determinadas para cada domínio do indicador E1, passando esta a constituir uma chance prévia que é usada para a determinação no domínio de E2 e sucessivamente para os domínios dos diversos indicadores. (Soares, ibdem) (griffo nosso)

$$
\begin{aligned}
& \mathrm{Ch}(\mathrm{H} / \mathrm{E}, \mathrm{nE}, \mathrm{iE})=\mathrm{Ch}(\mathrm{H}) . \mathrm{Fs}, \mathrm{n}, \mathrm{i}_{1} . \mathrm{Fs}, \mathrm{n}, \mathrm{i}_{2} . \mathrm{Fs}, \mathrm{n}, \mathrm{i}_{3} \ldots \mathrm{Fs}, \mathrm{n}, \mathrm{i}_{\mathrm{n}} \\
& \mathrm{Ch}(\mathrm{nH} / \mathrm{E}, \mathrm{nE}, \mathrm{iE})=\mathrm{Ch}(\mathrm{nH}) . \mathrm{Fs}, \mathrm{n}, \mathrm{i}_{1} . \mathrm{Fs}, \mathrm{n}, \mathrm{i}_{2} . \mathrm{Fs}, \mathrm{n}, \mathrm{i}_{3} \ldots \mathrm{Fs}, \mathrm{n}, \mathrm{i}_{\mathrm{n}} \\
& \mathrm{Ch}(\mathrm{iH} / \mathrm{E}, \mathrm{nE}, \mathrm{iE})=\mathrm{Ch}(\mathrm{iH}) . \mathrm{Fs}, \mathrm{n}, \mathrm{i}_{1} . \mathrm{Fs}, \mathrm{n}, \mathrm{i}_{2} . \mathrm{Fs}, \mathrm{n}, \mathrm{i}_{3} \ldots \mathrm{Fs}, \mathrm{n}, \mathrm{i}_{\mathrm{n}}
\end{aligned}
$$

Onde Fs,n,i representa os fatores modificadores para cada condição do indicador (presente, ausente ou incerto, respectivamente para cada indicador).

Tendo-se a chance a posteriori calculada para as diversas condições do evento $(H$, onde já se sabe que evento ocorre; $\mathrm{nH}$, onde já se sabe que não ocorre e; $\mathrm{iH}$, onde existe a dúvida sobre sua existência ou não), e considerando que a probabilidade do evento e seu complemento soma 1 (ou seja, são mutuamente excludentes, na medida que tendo $\mathrm{H} \mathrm{e}$ tendo $\mathrm{nH}$, é possível conhecer $\mathrm{iH}$ ) calcula-se o valor de probabilidade de cada condição do evento.

Como exemplo do método, temos uma área amostral (domínio investigativo) divida em celas iguais (condição de observação não viciada), cada qual representando uma fração do universo total de celas consideradas (casos discretos do universo=1). Em seguida serão inferidas algumas variáveis (indicadores) que apresentam relações ou expectativas de dependência com a ocorrência do evento (para o caso de se procurar a ocorrência do evento). Em cada cela, serão verificadas as condições de existência, não existência e ambiguidade de cada indicador considerado, mas também onde ocorrem e não ocorrem eventos já conhecidos.

De forma similar às considerações apontadas por Rostirolla et al. (1998 p.8), nos primeiros estágios da quantificação, as subáreas (celas) do espaço amostral que revelam conter 
eventos conhecidos, são marcadas como áreas de controle e representadas em termos de suas coordenadas geográficas e de valores em termos da influência de determinadas variáveis em contribuir ou não para a existência do evento. Tendo um modelo de ocorrência do evento, o peso pode ser calculado a partir das freqüências com os quais as variáveis diagnósticas se associam aos eventos conhecidos.

Ainda neste sentido, os dois principais estágios de avaliação consistem na seleção dos indicadores e à sua ponderação em termos do quanto satisfazem as condições de necessidade e suficiência envolvidas na predição do evento. Como ressaltam os autores, a necessidade e suficiência das variáveis são as mais importantes propriedades utilizadas na quantificação de favorabilidade.

Para que haja a compreensão exata dos resultados da quantificação, torna-se necessário esclarecer melhor esses dois conceitos fundamentais. No quadro abaixo, são apresentados algumas definições gerais e exemplos:

Quadro 5: Definições gerais e exemplos das condições de necessidade e suficiência da variáveis (fonte: Soares et al., 2002, adaptado)

\begin{tabular}{|c|c|c|}
\hline Condições & SUFICIENCIA & NECESSIDADE \\
\hline Definição geral & $\begin{array}{l}\text { - uma variável é tanto mais suficiente quanto } \\
\text { maior a proporção do evento em que ela está } \\
\text { presente; } \\
\text { - } \quad \text { a condição de suficiência de uma variável é } \\
\text { satisfeita quando a probabilidade da existência do } \\
\text { evento é aumentada com a existência da variável; } \\
\text { - A suficiência mede a veracidade de "se E é } \\
\text { verdade, então H também é verdade" }\end{array}$ & $\begin{array}{l}\text { - } \quad \text { uma variável é dita mais necessária quanto } \\
\text { mais ela está ausente onde o evento não ocorre; } \\
\text { - } \quad \text { a condição de necessidade da variável é } \\
\text { satisfeita quando a probabilidade de não } \\
\text { existência do evento é aumentada com a não } \\
\text { existência da variável; } \\
\text { - A necessidade é uma medida da veracidade } \\
\text { da afirmação "se E é falsa então H não é } \\
\text { verdade" }\end{array}$ \\
\hline $\begin{array}{l}\text { Exemplos } \\
\text { arqueológicos }\end{array}$ & $\begin{array}{l}\text { A existência de lâminas de machado de pedra com } \\
\text { moradores de uma determinada área é um indício } \\
\text { suficiente da probabilidade da existência de sítios } \\
\text { arqueológicos nesta área. } \\
\text { Qual a chance desta variável ser suficiente? }\end{array}$ & $\begin{array}{l}\text { Se não houver depósitos sedimentares do mesmo } \\
\text { período das ocupações caçadoras coletoras, } \\
\text { então provavelmente não haverá sítios enterrados } \\
\text { relativos a essas ocupações; } \\
\text { Qual a chance desta variável ser necessária? }\end{array}$ \\
\hline
\end{tabular}

O modelo probabilístico depende de um modelo que correlacione as características esperadas do evento, quanto às condições de necessidade e suficiência dos indicadores, independentemente de relações genéticas previamente verificadas. Assim, a proposta de geração de um mapa de favorabilidade para a preservação e detecção de sítios encobertos na planície costeira de Guaratuba / PR terá por base o modelo geral de trapeamento de sítios (Figura 25) e a ocorrência de sambaquis dispostos em sua atual superfície (conforme mapa da Figura 20 ). Deste modo associa-se à existência ou previsão de ocorrência de um "evento arqueológico" com a associação de elementos geomórficos ou fatores geológicos passíveis de respostas do tipo aporte sedimentar=preservação de sítio. Assim a probabilidade de sua ocorrência ou descoberta será representada em um mapa através de limiares de probabilidades condicionais (Soares, 2002 p.62). 


\subsubsection{Técnicas utilizadas e seleção dos indicadores}

O método constou inicialmente da delimitação de uma área piloto existente na área da planície costeira e baia de Guaratuba, onde será testado o modelo preditivo. Esta área não envolveu todos os compartimentos apresentados no mapa da Figura 20 . O motivo para esse recorte se deve a fatores interpretativos (que serão vistos no capítulo seguinte) e a restrições de tempo no processamento dos dados e informações. Neste sentido; procurouse focalizar àquele setor considerado com as melhores chances da ocorrência do evento de preservação arqueológica e ao mesmo tempo, que permitisse indicar situações favoráveis de detecção. Assim foi focalizada uma área mais interna da planície costeira, situada a oeste e sul das águas da baia de Guaratuba, que acompanha os cursos dos rios São João, Cubatão e Descoberto, cuja característica principal está na presença de extensos depósitos paleolagunares em associação com diferentes ambientes geomórficos e sedimentares

$\mathrm{Na}$ avaliação da potencialidade da preservação de sítios, tanto as evidências indicadoras quanto os eventos (preservação) precisam ser conhecidos em um mesmo espaço amostral a partir de observações não viciadas de casos discretos deste espaço (Soares, op cit, p.61)

As condições de necessidade e suficientica de cada indicador (E), foi feita tendo em vista as probabilidade prévias de cada cela em função das condições do evento conhecido e, através das relações de probabilidade de cada condição de indicador em cada cela, tendo em conta o número total de celas amostradas. O estabelecimento de "celas" segue os princípios da análise probabilística condicional onde as celas que contém sítios preservados são consideradas como um subconjunto do conjunto total de dados (insere deste modo, a influência do fator área/domínio investigativo e sua representatividade sobre as conclusões da pesquisa).

Tendo em conta a caracterização, a distribuição dos diversos indicadores e da ocorrência de sítios arqueológicos conhecidos foi feita por meio de uma malha regular de observações georreferenciadas (Soares, 2002, p.70) com 196 celas alinhadas pela grade UTM (Figura 26) contendo cada uma dimensões de $1 \mathrm{~km} \times 1 \mathrm{~km}$ (área de $1.000 .000 \mathrm{~m}^{2}$ ), sendo que no total as celas cobrem uma área de $196 \mathrm{~km}^{2}$. Para o registro das observações, dois tipos de planilhas foram construídas: a primeira contendo conhecimento sobre a existência ou não de eventos conhecidos em cada cela da área amostral; e o segundo, as matrizes geradas pela verificação dos indicadores e seus estados (E, nE, Ei) avaliados nas mesmas 196 celas. O valor de georreferência de cada cela correspondeu às coordenadas $\mathrm{x}$ e y do ponto central. Para indicar a presença, ausência ou incerteza (ambigüidade) de cada evento (Tabela 1) ou variável (Tabela 2), foi atribuído o valor $1,-1$ ou 0 respectivamente. 


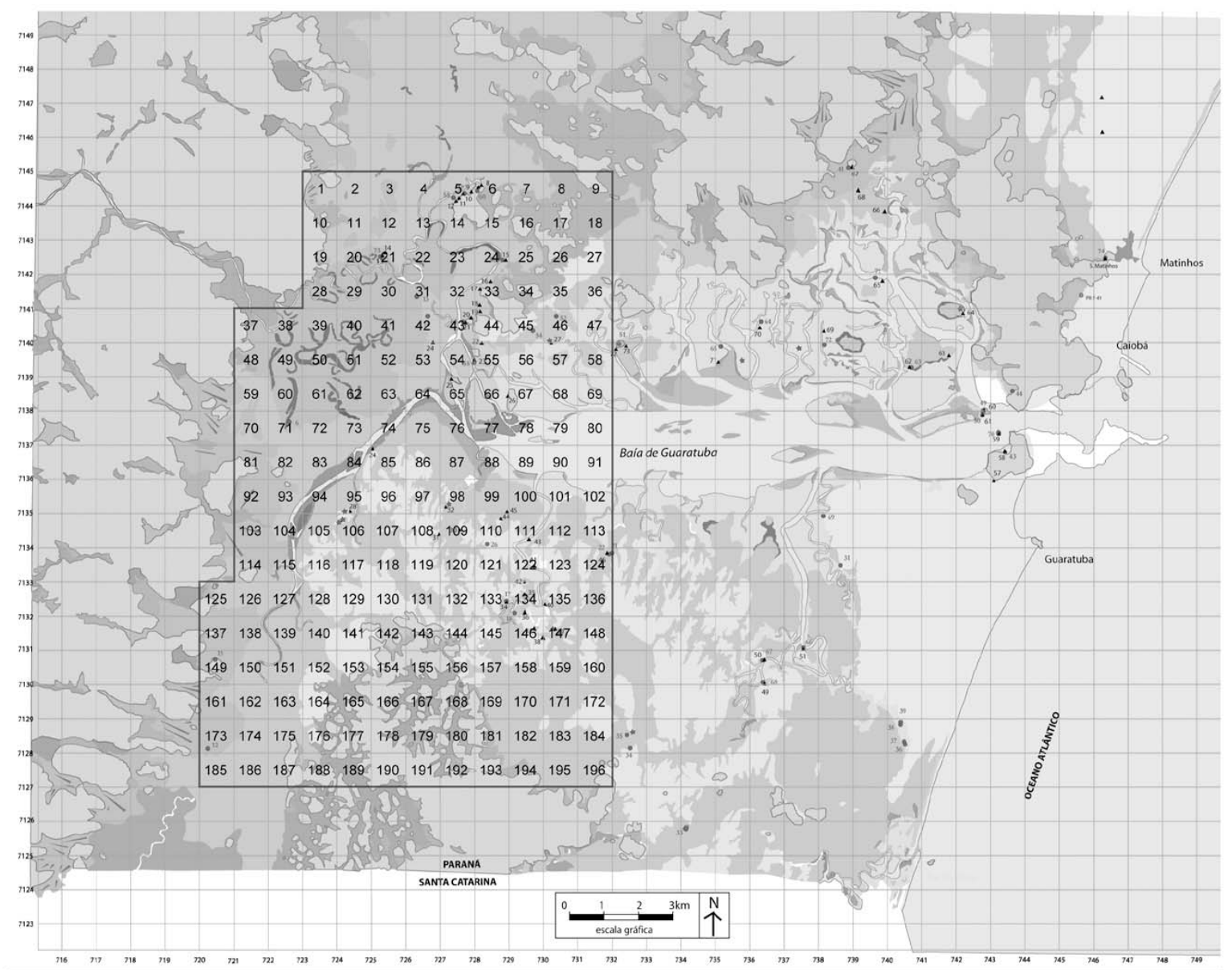

Figura 26:Área piloto onde será desenvolvido o modelo preditivo com a numeração das celas de observação (1 km x $1 \mathrm{~km})$

Tabela 1: Exemplo de tabela contendo o diagnóstico de casos conhecidos ou desconhecidos por cela, com quatro colunas; a quarta é se a ocorrência (o evento procurado) existe no local.

\begin{tabular}{|c|c|c|c|}
\hline Celas & Coord. X & Coord. Y & 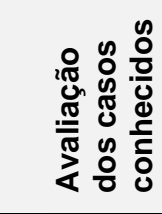 \\
\hline 1 & 723.5 & 7144.5 & -1 \\
\hline 2 & 724.5 & 7144.5 & -1 \\
\hline 3 & 725.5 & 7144.5 & 0 \\
\hline 4 & 726.5 & 7144.5 & -1 \\
\hline 5 & 727.5 & 7144.5 & 1 \\
\hline 6 & 728.5 & 7144.5 & 1 \\
\hline 7 & 729.5 & 7144.5 & 1 \\
\hline 8 & 730.5 & 7144.5 & -1 \\
\hline
\end{tabular}


Tabela 2: Exemplo da construção da segunda planilha contendo o diagnóstico espacial dos diferentes indicadores por cela

\begin{tabular}{|c|c|c|c|c|c|c|c|c|c|}
\hline cela & Coord. X & Coord. Y & $\begin{array}{l}\frac{\overline{0}}{4} \\
\frac{\pi}{0} \\
\frac{d}{\pi} \\
\frac{0}{1} \\
\frac{0}{1}\end{array}$ & $\begin{array}{l}\frac{d}{\vec{g}} \\
\frac{\mathrm{d}}{\mathrm{d}} \\
\frac{\mathrm{d}}{\sigma} \\
\frac{1}{\mathrm{~N}}\end{array}$ & 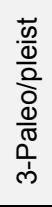 & 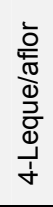 & 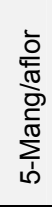 & 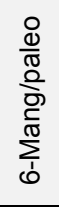 & 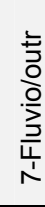 \\
\hline 1 & 723.5 & 7144.5 & 1 & 1 & -1 & 1 & -1 & -1 & -1 \\
\hline 2 & 724.5 & 7144.5 & 1 & -1 & -1 & -1 & -1 & -1 & 0 \\
\hline 3 & 725.5 & 7144.5 & -1 & 0 & -1 & -1 & -1 & -1 & -1 \\
\hline 4 & 726.5 & 7144.5 & -1 & -1 & -1 & -1 & -1 & 0 & 1 \\
\hline 5 & 727.5 & 7144.5 & 1 & -1 & -1 & -1 & 0 & -1 & 1 \\
\hline 6 & 728.5 & 7144.5 & 1 & -1 & -1 & -1 & -1 & -1 & 1 \\
\hline 7 & 729.5 & 7144.5 & 1 & 0 & -1 & -1 & -1 & -1 & 1 \\
\hline 8 & 730.5 & 7144.5 & 1 & 0 & -1 & -1 & -1 & -1 & 0 \\
\hline
\end{tabular}

O primeiro passo foi verificar a ocorrência de eventos conhecidos em cada cela de $1 \mathrm{~km} 2$. Considerou-se neste caso, que a presença de um ou mais sambaquis em uma cela é um registro do evento que se procura, ou seja, evento de preservação arqueológica. Nesta análise, o número de sambaquis por cela e as condições atuais de preservação de cada sítio não foram considerados como elemento distintivo ${ }^{43}$. Assim, nas 196 celas foram observados 32 casos de ocorrência do evento $(P)$. Para a atribuição das não ocorrências $(\mathrm{nP}=-1)$ e incertezas ( $\mathrm{P}=0$ ) adotou-se duas possibilidades: 1) que as celas restantes fossem consideradas ambíguas (valor 0) em relação a ocorrência ou não ocorrência de sambaquis. Neste caso a ambigüidade representaria um valor de probabilidade de $50 \%$ de ocorrer e $50 \%$ de não ocorrer $\mathrm{P}$; 2) foi inserido um novo conhecimento no sistema, através da atribuição daquelas celas nas quais foi inferida uma "certeza" de não ocorrência (-1) de sambaquis preservados (como no caso de celas ocupadas por morros elevados). Com a inserção desse conhecimento no sistema, são modificadas as probabilidades prévias de cada condição de evento em cada cela, gerando um mapa distinto de chances do evento. Assim foi possível gerar distribuições diferenciadas de probabilidade condicional permitindo sua comparação e tomadas de decisão sobre as melhores expectativas detecção de alvos 44

\footnotetext{
${ }^{43}$ Mas que no entanto, podem ser futuramente incluídos como fator de conhecimento destinado a melhorar a análise das condições do evento no modelo.

${ }^{44} \mathrm{~A}$ possibilidade da constante inclusão de novos conhecimentos de forma independente à ordem de processamento, é uma das grandes vantagens no uso de modelos de sistemas dinâmicos baseados
} 
Quanto à seleção dos indicadores foram utilizadas variáveis geomórficas, geológicas e hipotéticas consideradas com alguma probabilidade de dependência com existência do evento de preservação. A segui serão descritos os indicadores potenciais utilizados e sua justificação:

1) Relações de contato entre substratos potencialmente "selantes" : Tomou por base a observação dos tipos de contato entre depósitos sedimentares/substrato apresentados em cada cela, bem como, a inferências sobre a energia e evolução estratigráfica dos ambientes envolvidos em cada tipo de depósito. Este tipo de classificação baseou-se em uma investigação prévia sobre os tipos presentes no entorno de cerca de 80 sambaquis em Guaratuba. Assim, diferentemente das classificações de substratos, esta análise voltou a caracterização do depósitos de entorno (cerca de $1 \mathrm{~km}$ ) e suas relações estratigráficas

Assim primeiramente considerou-se que os depósitos associados ambientes estuarinos de planicies de maré e planícies de sedimentos paleoestuarinos constituem os tipos litológicos selantes mais aptos a preservação de sitios. Esta análise reconhece que possam existir fácies de canais de maré ou fundos rasos associados, que ao contrário são elementos desfavoráveis ao evento..Outro elemento selante refere-se a depósitos aluvionares, seja aqueles relativos a ocorrência de leques aluviais seja, os depósitos fluviais. Considerando a posição da área piloto e o mapa geológico, não foi considerado a situação de depósitos eólicos.

Os tipos selecionados

Tipo 1: Depósitos paleoestuarinos em contato com afloramentos rochosos e colúvios (Paleo laflor)

Tipo 2: Depóstios paleoestuarinos em contato com leques aluvionares (Paleo / leque)

Tipo 3: Depósitos paleoestuarinos em contato com terraço pleistocênico (Paleo / pleist)

Tipo 4: Depósito de leque aluvial sobre afloramento (Leque / aflor)

Tipo 5: Depósitos de planícies de maré (mangue) em contato com afloramentos ou colúvios (mangue / aflor)

Tipo 6: Depósitos de planícies de maré (mangue) em contato depósitos paleoestuarinos (mangue / paleo)

em conhecimento (como em programas de Inteligência Artificial) daqueles gerados por meio de modelos dinâmicos puramente empíricos e analógicos. No entanto, é bom frisar, que isto não diz nada sobre a validade ou relevância desses novos conhecimentos na resolução dos problemas considerados. 
Tipo 7: Depósitos fluviais ou fluvio lagunares em contato com os demais depósitos ou afloramentos (Flúvio / outros)

2) Direção dos contatos litológicos mais antigos capazes de formar áreas protegidas à retaguarda. Na escala considerada de análise (celas de $1 \mathrm{~km}$ ) tais lineamento apresentam também alguma correspondência com supostas direções de paleovales, ou antigos lineamento de cordões litorâneos

Ao considerar a direção média dos lineamentos litorâneos sugestivo de corresponder a frentes de embate do ondas por ação de ventos. Foi considerado neste caso o angulo de $20^{\circ}$ (N20E) como eixo tranversal, e portanto, com maior sombra. Com base neste eixo, foi determinado quatro tipos de variações nos ângulos conforme a Figura 27

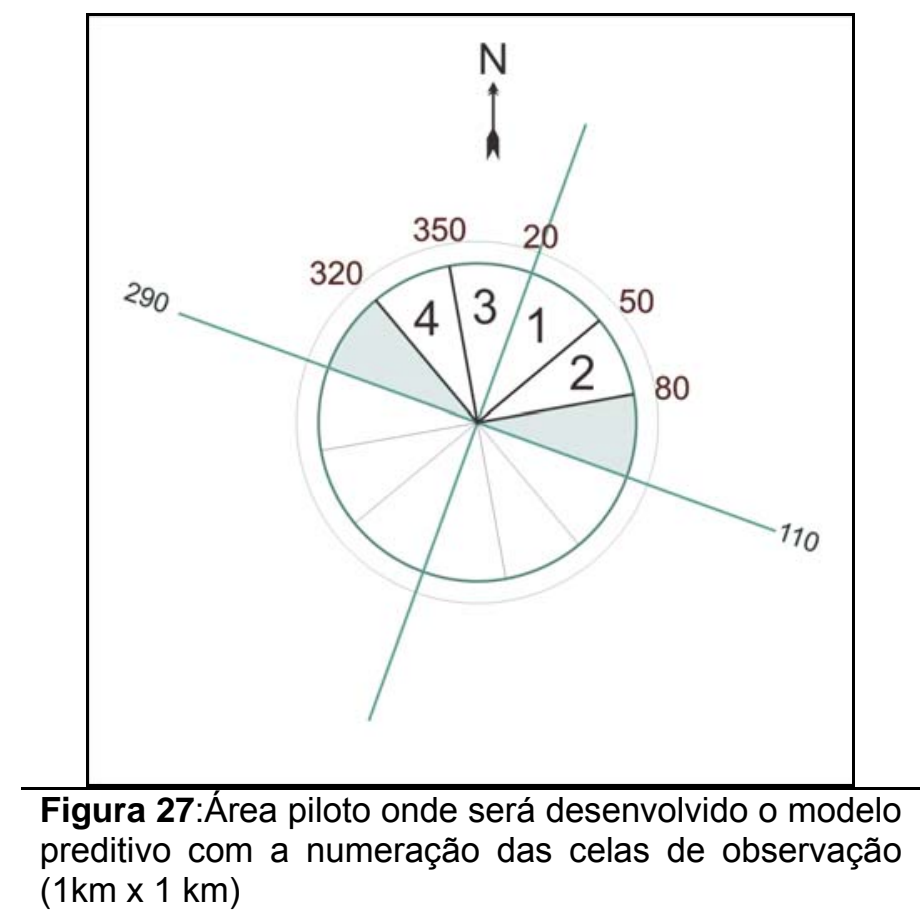

Tipo 8 - s(020-050)

Tipo 9 - s(050-080)

Tipo 10 - s(350-020)

Tipo 11 - s(320-350)

3) foi indicado uma variável (denominada de Tipo 12) como índice de preservação. O índice de preservação leva em conta o tamanho e número de canais existentes por cela, bem como a presença de elementos que sugerem menor erosão em termos como a manutenção de terraços pleistocênicos, a presença de leques aluvionares (maior aporte sedimentar.) etc 
4) Presença de Células de contenção de sedimentos em situações de refração de embate de ondas ou correntes (Figura 28) Tais células ao contrario, dos alinhamento de sombra independem da posição ou direção onde se encontram.

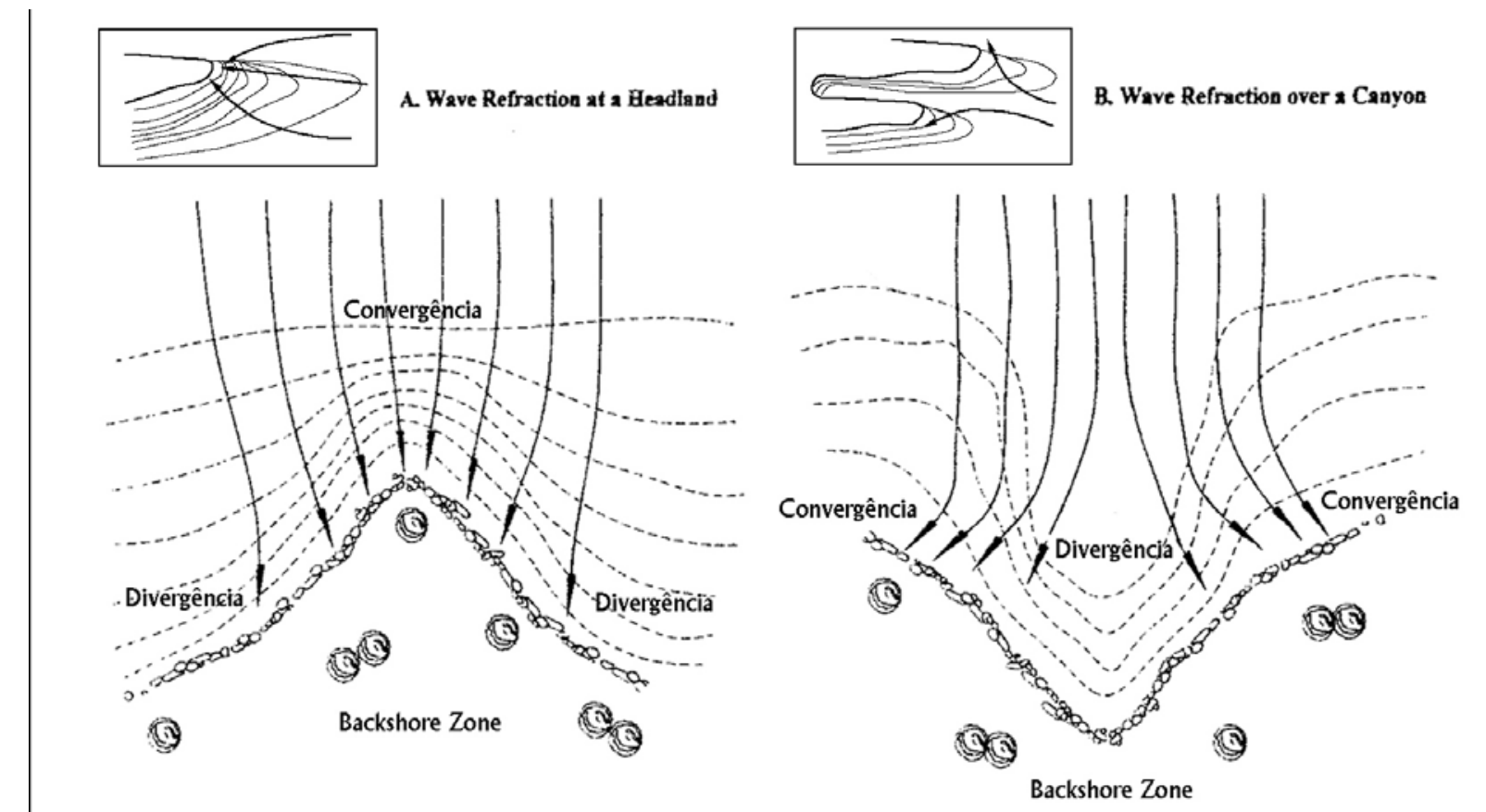

Figura 28:Área piloto onde será desenvolvido o modelo preditivo com a numeração das celas de observação $(1 \mathrm{~km} \times 1 \mathrm{~km})$

Tipo 13 - -c.cont - existência de células de contenção: variável de que indica apenas se existem células favoráveis à contenção de sedimentos nas selas de observação; Esta variável também foi considerada por apontar a situação de não existência de célula.

5) número de células de contenção número de células: variável que tem por objetivos estabelecer quais celas apresenta maior numero de situação de células e se tais situações correspondem a melhores condições de preservação

Tipo 14 - cont(7-10) - varia de 7 a 10 células por cela de observação

Tipo 15 - -cont $(\geq 11)$ - mais de 11 células por cela de observação

6) feições de sustentação: associada a feições tais como barras em pontal ou promontórios, onde depósitos mais antigos apresentam saliências convexas sugestivas de locais preservados

Tipo 16 - -c.cont - existência de células de contenção

Tipo 17 sust(3-5) número de feições de sustentação

Tipo 18-sust( $(\geq 6)$ número de feições de sustentação 
7) Tipo 19-pal vale - inferência sobre antigos paleo vales com base em cálculos de distancia média e mapas hiposométricos

\subsubsection{Determinação dos pesos e aplicação do modelo probabilístico}

Para a estimativa de favorabilidade dois passos são considerados necessários: 1) a determinações dos pesos de cada indicador, a partir das relações de freqüências entre indicadores e eventos conhecidos; 2) aplicação do modelo probabilistico, que permitirá avaliar as condições de favorabilidade de cada cela, de modo que se possa verificar o maior risco do evento ocorrer mesmo naquelas celas favoráveis mas que ainda não contém o evento (Soares, 2002, p. 70).

Seguindo Chung et al. (1992) e Rostirolla et al (1998), na determinação de pesos é considerado como altamente necessárias $[P(H / E)=$ máximo] aquelas variáveis que na sua maioria estão fortemente associadas ao evento e, altamente suficientes $[P(H / E)=$ Maximo] aquelas variáveis que podem ou não estar associadas, mas quando presentes fornecem forte evidência da ocorrência do evento (Figura 29). Deste modo um indicador de ocorrência ampla e situado fora dos eventos conhecidos poderá ser considerado no peso, assim como um indicador que não influência na ocorrência desses eventos, poderá ser classificado pelo ponderador, como um critério diagnóstico forte da ocorrência de novos eventos.

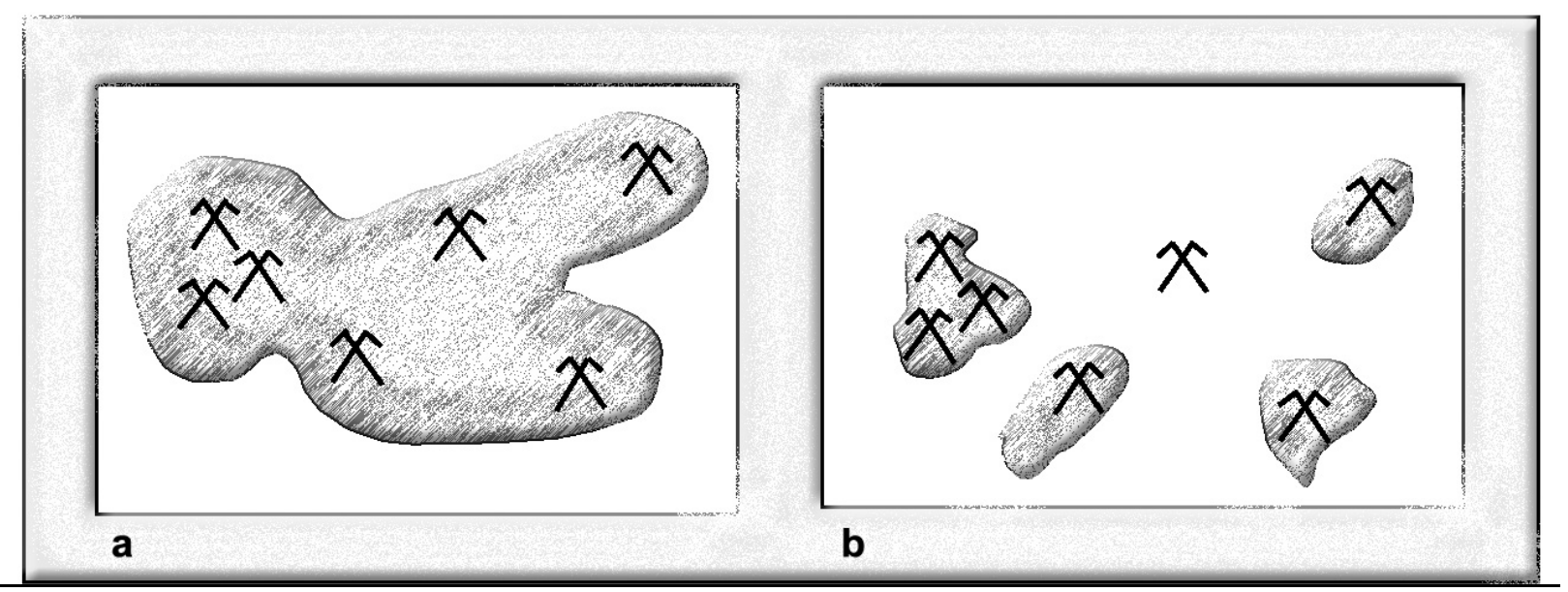

Figura 29:Representação empírica das condições de necessidade (a) e suficiência (b), com os símbolos representando os eventos e áreas rachuradas a distribuição da variável (indicador) considerada

Cabe citar, que conforme Soares (comunição pessoal) esta é a situação mais simples de entrada, existindo ainda outras formas. A mais complexa é por grupos e inclui um arquivo modelo, para o tipo ideal de evento (como no caso de um sistema petrolífero, por exemplo), mais uma avaliação da confiabilidade das evidências.

Segundo as formulas apresentadas no item 7.1.1, a Chance (razão entre as probabilidades e seus espaços complementares) de cada condição do evento $(\mathrm{H}, \mathrm{nH}, \mathrm{iH})$ poderá ser 
determinada pelo calculo de um valor de chance prévia multiplicado pelo cálculo da probabilidade das condições de cada indicador ( $E, n E, i E)$ avaliado em cada cela. Conforme Soares (op cit, p.71) a chance prévia é a razão entre a probabilidade de ocorrer e a de não ocorrer, independentemente de qualquer fator. No entanto, ambos os valores serão estimados pela probabilidade experimental, observada a partir de eventos já ocorridos (a posteriori). Neste caso, entretanto, o valor calculado não é o valor ideal pois não inclui toda a probabilidade de ocorrer. Torna-se necessário admitir uma chance prévia maior que aquela resultante das observações ${ }^{45}$. Os programa Anfavin (Soares, 1999a) e Belin (Soares, 1999b) que são usados para ajuste e calibração do modelo permitem admitir uma situações valores de chance prévia maiores a serem utilizados

\subsubsection{Resultados}

Como visto foram verificados 32 casos de ocorrências de sambaquis nas 196 celas da área amostral no setor interno da Baia de Guaratuba. Foram consideradas então e possibilidades para as 164 celas restantes: 1) que fosse informado que nas nas celas restantes o evento (sambaquis) não existe (-1). Neste sentido, o método exposto por Agterberg foi modificado para calcular a ambiguidade $(-1=0)$ dessas afirmações perante a ocorrência ou não dos indicadores. O resultado pode ser visto

Neste caso a ambigüidade representaria um valor de probabilidade de $50 \%$ de ocorrer e $50 \%$ de não ocorrer $\mathrm{P}$; 2) foi inserido um novo conhecimento no sistema, através da atribuição daquelas celas nas quais foi inferida uma "certeza" de não ocorrência (-1) de sambaquis preservados (como no caso de celas ocupadas por morros elevados).

Com o calculo de pesos e das probabilidades (Quadro 6, tabela 3, Anexo 1) foi gerado o mapa da Figura 30 e, com a inserção de novos conhecimentos e técnicas distintas, foram gerados os mapas da Figuras 31.

\footnotetext{
${ }^{45}$ O programa Anfabin (Soares 1999) que é usado para ajuste e calibração do modelo permite admitir diferentes situações de valores de chance prévia a serem utlizados
} 
EVIDENCIAS (1 modelo)

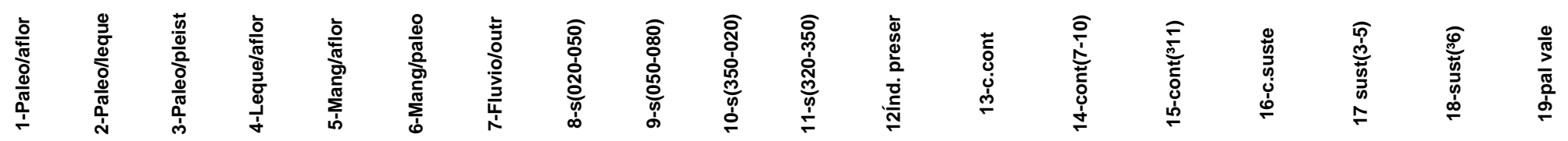

PROBABILIDADE PREVIA DE E.

PROBABILIDADE DE P DADO E:.....

PROBABILIDADE DE P DADO nE:....

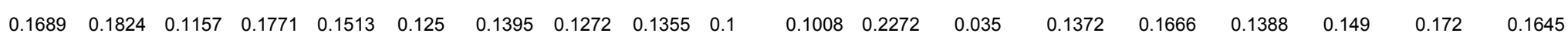

PROBABILIDADE DE P DADO E,nE:.

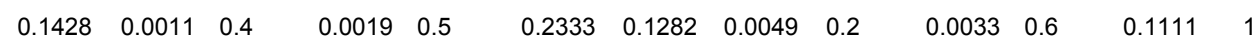

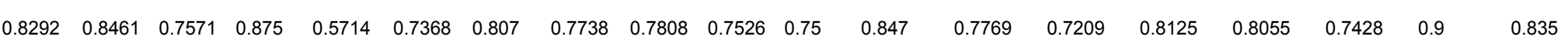

PROBABILIDADE DE nP DADO E: ...

$\begin{array}{lllllllllllllllllllll}0.8571 & 1 & 0.6 & 1 & 0.5 & 0.7666 & 0.8717 & 1 & 0.8 & 1 & 0.4 & 0.8888 & 1 & 1 & 1 & 0.75 & 1 & 1 & 0.8\end{array}$

PROBABILIDADE DE nP DADO E,nE:

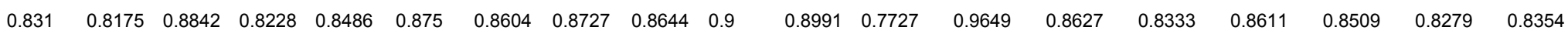

PROBABILIDADE DE nP DADO nE: .

$\begin{array}{lllllllllllllllllllll}0.0002 & 0.0002 & 0.0001 & 0.0006 & 0.0014 & 0.0002 & 0 & 0.0001 & 0.0001 & 0.0001 & 0.0001 & 0.0001 & 0 & 0.0002 & 0.0006 & 0.0001 & 0.0002 & 0.0009 & 0.0001\end{array}$

PROBABILIDADE DE P,nP DADO E:..

$\begin{array}{lllllllllllll}0.0014 & 0.0011 & 0.0019 & 0.0019 & 0.0024 & 0.0003 & 0.0002 & 0.0049 & 0.0019 & 0.0033 & 0.0019 & 0.0002 & 1\end{array}$

1

PROBABILIDADE DE P,nP DADO E,nE:

PROBABILIDADE DE P,nP DADO nE:

\section{Tabela 3}

METODO:

AGTERBERG

CHANCE PREVIA

0,202454 


\begin{tabular}{|c|c|c|c|c|c|}
\hline \multicolumn{6}{|l|}{ Quadro 6} \\
\hline EVIDÊNCIA & $\begin{array}{c}\mathrm{LN}(\mathrm{E})=\mathrm{Log} \\
\mathrm{P}(\mathrm{P} / \mathrm{nE}) / \mathrm{p}(\mathrm{nP} / \mathrm{nE}) \\
\text { Necessidade }\end{array}$ & $\begin{array}{c}L S(E)=\log \\
P(P / E) / p(n P / E) \\
\text { Suficiência }\end{array}$ & $\begin{array}{c}\operatorname{LAS}(E)=\log \\
\text { AMBIG-S }\end{array}$ & AMBIG-N & $\begin{array}{c}\mathrm{COM}(\mathrm{E})= \\
\mathrm{LS}(\mathrm{E})-\mathrm{LN}(\mathrm{E}) \\
\text { Contraste }\end{array}$ \\
\hline 13-c.cont & -17169 & 0.3491 & 0.0003 & 0.0001 & 20660 \\
\hline 5-Mang/aflor & -0.1268 & 13096 & 0.0606 & 0.0123 & 14364 \\
\hline $11-\mathrm{s}(320-350)$ & -0.5907 & 0.4986 & 0.0909 & 0.0123 & 10893 \\
\hline $10-\mathrm{s}(350-020)$ & -0.6000 & 0.4842 & 0.0003 & 0.0184 & 10842 \\
\hline 6-Mang/paleo & -0.3487 & 0.5676 & 0.2121 & 0.1411 & 0.9163 \\
\hline 3-Paleo/pleist & -0.4365 & 0.4602 & 0.0606 & 0.0184 & 0.8967 \\
\hline $14-\operatorname{cont}(7-10)$ & -0.2410 & 0.6482 & 0.0003 & 0.0001 & 0.8892 \\
\hline $8-\mathrm{s}(020-050)$ & -0.3280 & 0.3673 & 0.0003 & 0.0123 & 0.6953 \\
\hline 17 sust(3-5) & -0.1447 & 0.5364 & 0.0003 & 0.0001 & 0.6811 \\
\hline $9-\mathrm{s}(050-080)$ & -0.2551 & 0.3268 & 0.0303 & 0.0245 & 0.5819 \\
\hline 16-c.suste & -0.2273 & 0.1759 & 0.1212 & 0.0736 & 0.4032 \\
\hline 7-Fluvio/outr & -0.2219 & 0.1665 & 0.1515 & 0.2086 & 0.3884 \\
\hline $15-\operatorname{cont}\left({ }^{3} 11\right)$ & -0.0122 & 0.1309 & 0.0003 & 0.0001 & 0.1431 \\
\hline 1-Paleo/aflor & 0.0039 & 0.0168 & 0.0303 & 0.0368 & 0.0129 \\
\hline
\end{tabular}




\begin{tabular}{|c|c|c|c|c|c|}
\hline 19-pal vale & -0.0275 & -0.0246 & 0.1212 & 0.0982 & 0.0028 \\
\hline 2-Paleo/leque & 0.0973 & -0.1075 & 0.0003 & 0.0552 & -0.2048 \\
\hline 4-Leque/aflor & 0.0614 & -0.3487 & 0.0003 & 0.0307 & -0.4101 \\
\hline 12́nd. preser & 0.3735 & -0.1145 & 0.1515 & 0.2454 & -0.4879 \\
\hline 18-sust( $\left.{ }^{36}\right)$ & 0.0260 & -0.6000 & 0.0003 & 0.0001 & -0.6260 \\
\hline
\end{tabular}

Pelo calculo dos indicadores verifica-se os seguintes resultados:

- Indicador 13 (melhor discrimina) são reentrancias concavas capazes de aprisionar sedimentos; a

- Indicador 6 (ambigua para indicar) refere-se a associação mangue/paleoestuarino que em geral apresenta muitos canais (que é um fator negativo);

- Indicador 12 (ambiqua para indicar que não tem) é um indice de preservação que está associado inversamente a presença de canais. Sua ambiguidade se deu pelo fato de que muitos sambaquis (sitios costeiros) estão próximos de canais;

- Indicador 10 (ausência indica que não tem; presença não indica nada) é uma direção que indica "sombra" formada na retaguarda de afloramentos rochosos. O fato de aparecer este indicador pode representar tanto a preferência pela ocupação deste compartimento ambiental, quanto à baixa incidência de processos erosivos (que permitiram preservar os sítios em detrimento de outros). 


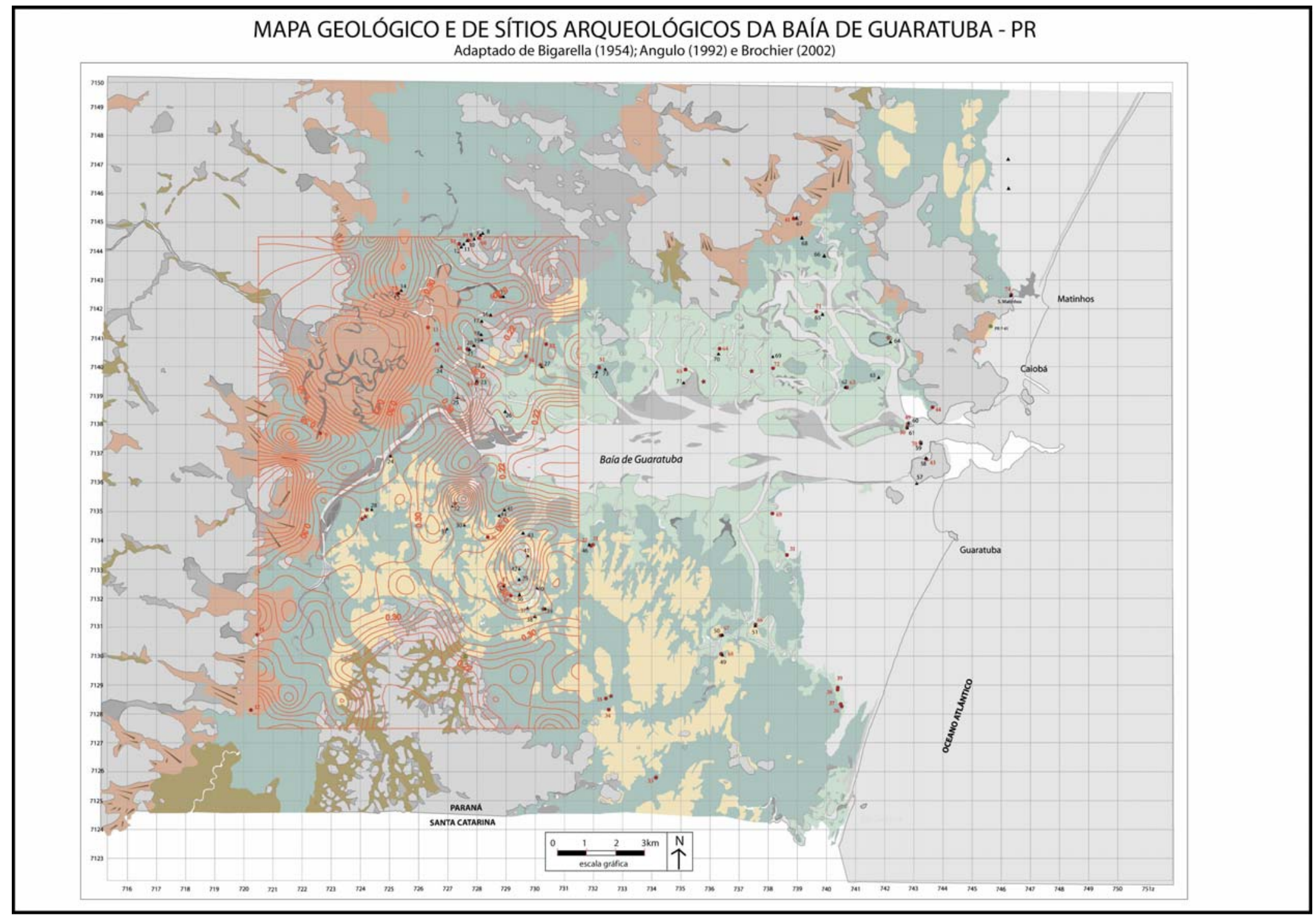

Figura 30 

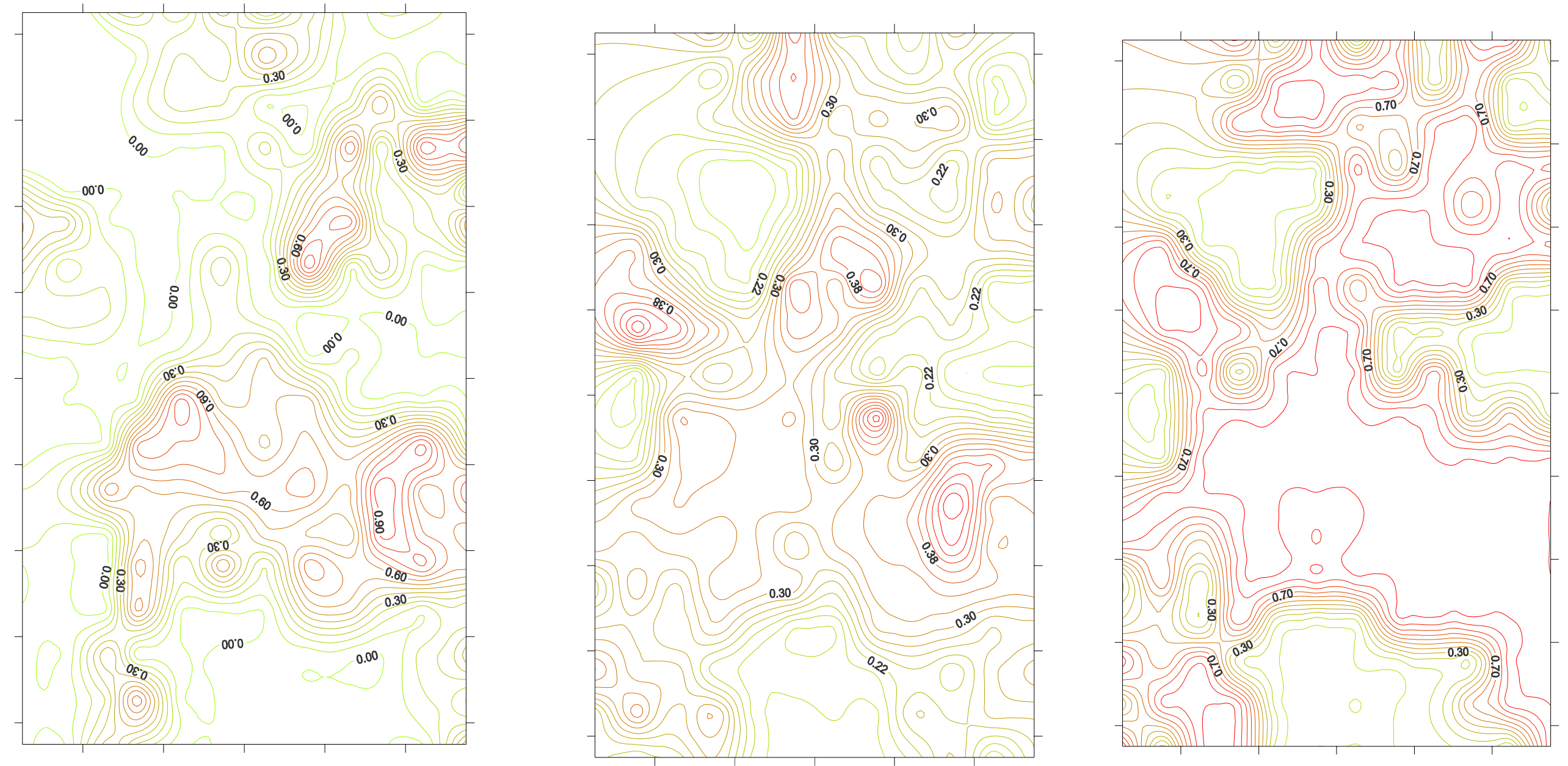

Figura 31 


\section{REFERÊNCIAS BIBLIOGRÁFICAS}

AB'SABER, A. Brasil: Paisagens de Exceção. O Litoral e o Pantanal Mato-Grossense: patrimônios básicos. Cotia, SP: Ateliê Editorial, 2006.

ANDREATTA, M. D.; MENEZES, M. J. Dados parciais das pesquisas no sambaqui B do Guaraguaçu. Revista do Museu Paulista, São Paulo, n.22, p. 135-165, 1975.

ANGELINI, R. Bases para a aplicação da teoria da informação em ecossistemas, com ênfase na ascendência. Acta Scientiarum. Maringá, v. 24, n. 2, p. 275-283, 2002

ANGULO, R. J.; ARAÚJO, A.D. 1996 Classificação da Costa Paranaense com Base na sua Dinâmica, como Subsídio à Ocupação da Orla Litorânea. Boletim Paranaense de Geociências, 44:7-17. Curitiba, PR

ANGULO, R.J. 1992 Geologia da planície costeira do Estado do Paraná, Tese de Doutoramento, 334p., IG/USP. São Paulo,

ANGULO, R.J. 2004. Mapa do litoral do Estado do Paraná. Boletim Paranaense de Geociências, Curitiba, v. 55, n. 1, p. 16-30, 2004.

ANGULO, R.J.; LESSA, G. C 1997 The Brazilian Sea-Leavel Curves: a Critical Review with Emphasis on the Curves from the Pranaguá and Cananéia Regions. Marine Geology, Netherlands: Elsevier Science, 140:141-166.

ANGULO, R.J.; LESSA, G. C; SOUZA, M.C de A. 2005. A critical review of the mid- to late Holocene sea-level fluctuations on the eastern brazilian coastline. Quaternary Science Reviews, Londres, p.121, 2005.

ANGULO, R.J.; SUGUIO, K. Re-evaluation of the maxima of the Holocene sea-level Palaeogeography, Palaeoclimatology, Palaeoecology, Volume 113, N 2, February 1995, pp. 385393(9).

APA GUARATUBA. Zoneamento Ecológico-Econômico e Plano de Manejo da Área de Proteção Ambiental (APA) de Guaratuba-PR. Instituto Ambiental do Paraná (IAP)/Diretoria de Biodiversidade e Áreas Protegidas (DIBAP)/PRÓ-ATLÂNTICA (Convênio Brasil-Alemanha) e SILVICONSULT ENGENHARIA LTDA. Curitiba, 2002.

ARAÚJO, A. G. M. As geociências e suas implicações em teoria e métodos arqueológicos. Rev. do Museu de Arqueologia e Etnologia, São Paulo, suplemento 3, p. 35-45, 1999.

ASCHER, R. Time's Arrow na the Archaeology of a Contemporary Community. In Settlement Archaeology. Edited by K. C. Chang, pp.43-52. National Press Books, Palo alto.1968

AZEVEDO, M. de A. Informação e interpretação: uma leitura teórico-metodológica. Perspect. ciênc. inf., Belo Horizonte, v.9 n.2, p. 122-133, jul./dez. 2004.

BEHLING, H. \& NEGRELLE, R. Late Quaternary tropical rain forest and climate dynamics from the Atlantic lowland in southern Brazil. Quaternary Research, v.53, p.369-377.

BESSA, Jr. O.; SUGUIO, K.; ANGULO, R.J. Leques aluviais quaternários do litoral paranaense. In: CONG. ASSOC. BRAS. EST. QUAT., 6, Curitiba. Resumos Expandidos... ABEQUA, Curitiba, PR. 1997

BIGARELLA, J. Variações climáticas no Quaternário Superior do Brasil e sua datação radiométrica pelo método do carbono 14. Paleoclimas. Universidade de São Paulo. São Paulo,1:1-22. 1971.

BIGARELLA, J.J. 1946 Contribuição ao estudo da planície litorânea do Estado do Paraná. Arquivos de Biologia e Tecnologia, 1:75-112. Curitiba, PR.

BIGARELLA, J.J. 1949 Nota Prévia sobre a Composição dos Sambaquis do Paraná e Santa Catarina. Arquivos de Biologia e Tecnologia, IBPT 4:95-106. Curitiba, PR.

BIGARELLA, J.J. 1950/51a Contribuição ao estudo dos sambaquis no Estado do Paraná I, Regiões adjacentes às Baías de Paranaguá e Antonina. Arquivos de Biologia e Tecnologia. Curitiba: IBPT, 5-6: 231-292. Curitiba, PR. 
BIGARELLA, J.J. 1950/51b Contribuição ao estudo dos sambaquis no Estado do Paraná II, Regiões adjacentes à Baía de Guaratuba. Arquivos de Biologia e Tecnologia. Curitiba: IBPT, 5/6:293-314. Curitiba, PR.

BIGARELLA, J.J. 1954 Os sambaquis na evolução da paisagem litorânea sul-brasileira. Arquivos de Biologia e Tecnologia, 9:199-221. Curitiba, PR.

BIGARELLA, J.J. 1959 O sambaqui da llha dos Ratos. Anhembi, 33(89):483-490. Curitiba, PR.

BIGARELLA, J.J. 1971 Variações climáticas no Quaternário Superior do Brasil e sua datação radiométrica pelo método do Carbono 14. Paleoclimas 1:1-22. Inst. Geogr. USP. São Paulo, SP.

BIGARELLA, J.J. 1976 Considerações a respeito das variações de nível do mar e datações radiométricas. Cadernos de Arqueologia, 1:105-117. Museu de Arqueologia e Artes Populares. Paranaguá, PR.

BIGARELLA, J.J. 1991 Matinho: Homem e Terra - Reminiscências... Matinhos:PMM/ADEA, 212p.

BIGARELLA, J.J. Contribuição ao estudo dos sambaquis no Estado do Paraná I, regiões adjecentes às baías de Paranaguá e Antonina. Arquivos de Biologia e Tecnologia. Curitiba, n.5/6, p. 231-292, 1950/51a.

BINFORD, L. A Consideration of Archaeological Research Design. American Antiquity, v. 29, n.4, p. 425-441, 1964.

BINFORD, L. A. Archaeological Perspectives. In: New Perspectives in Archaeology ed by S.R. Binford and L.R. Binford, pp. 5-32 Aldine, Chicago. 1968.

BINFORD, L.R. A Consideration of Archaeological Research Design. American Antiquity, Vol. 29, No. 4 (Apr., 1964), pp. 425-441.

BINFORD, L.R. Archaeology as Anthropology. American Antiquity, Vol. 28, No. 2. (Oct., 1962), pp. 217-225.

BINFORD, L.R. Em busca do Passado. Publicações Europa-América, Portugal. 304p, 1983.

BLASI, O; GAISSLER, M.; PONTES F. A; MACEDO, C.; PARELLADA, C.I.; MARANHÃO, M.F. Projeto de Cadastramento, pesquisa e proteção de sítios arqueológicos na região de Guaraqueçaba. Relatório Interno CNPq/IPARDES, Curitiba, 1987. 60 p.

BLUM, M.D.; ABBOTT, J.T.; VALASTRO, S. Evolutions of Landscapes on the Double Mountain Fork of the Brazoa River, West Texas; Implications for Preservation and Visibility of the Archaeological Record. Geoarchaeology: An International Journal, 7(4):339-370. 1992

BRANDT R. W.; VAN DER EEEUW, S. E; VAN WIJNGAARDEN-BAKKER, L. H. Transformations in a Dutch estuary: research in a wet landscape. World Archaeology, Vol. 16, No. 1, Coastal Archaeology. (Jun., 1984), pp. 1-17.

BRANDT, R.; GROENEWOUDT, B.J.; KVAMME K.L. An experiment in archaeological site location: modelling in the Netherlands using GIS techniques. World Archaeology 2, 268-282. 1992

BROCHIER, L. L. e MIGUEL, R.. O efeito dos processos erosivos e intempéricos sobre sítios arqueológicos situados na faixa de depleção do reservatório da UHE Capivari-Cachoeira-PR. Anais da XI Reunião Científica da Sociedade de Arqueologia Brasileira (Resumos), Rio de Janeiro, RJ. 2001.

BROCHIER, L. L. Relatório técnico de levantamento de recursos arqueológicos para o Plano de Manejo e Zoneamento Ecológico e Econômico da APA Guaratuba. Curitiba, 2002. 90p. Não Publicado.

BROCHIER, L.L. Diagnóstico e manejo de recursos arqueológicos em Unidades de Conservação: uma proposta para o litoral paranaense. 2004. 165f. Dissertação (Mestrado) Faculdade de Filosofia, Letras e Ciências Humanas, Universidade de São Paulo, São Paulo. 2004.

BROCHIER, Laércio L. O uso de Controles Geoarqueológicos: perspectivas para o estudo e caracterização de áreas arqueológicas na baía de Guaratuba. Anais da XI Reunião Científica da Sociedade de Arqueologia Brasileira (Resumos), Rio de Janeiro. 2001.

BROOKS, M.J.; TAYLOR, B.E.; GRANT, J. A. Carolina Bay Geoarchaeology and Holocene Landscape Evolution on the Upper Coastal Plain of South Carolina. Geoarchaeology: An International Journal, 11(6):481-504. 1996 
BROWN, A. G. Alluvial Geoarchaeology: Floodplain Archaeology and Environmental Change. Cambridge Manuals in Archaeology. Cambridge University Press, 1997.

BUCKLAND, Michael. Information as thing. Preprint of an article published in the Journal of the American Society of Information Science 42:5 (June 1991): 351-360.site: http://www.ischool.berkeley.edu/ buckland/thing.html consultado em 20/03/2007.

BUTZER, K. W. Geo-archaeology in practice. Reviews in Anthropology, v. 4, p.125-131, 1977.

CALDARELLI S.B; SANTOS, M. C. M. dos. Arqueologia de contrato no Brasil. Antes de Cabral: Arqueologia Brasileira I. Revista USP, São Paulo, n. 44, p. 52-73, dez./fev.1999-2000.

CAPURRO, Rafael. Epistemologia y ciência de la informacion. In: ENCONTRO NACIONAL DE PESQUISA EM CIÊNCIA DA INFORMAÇÃO, 5., 2003, Belo Horizonte. Anais... Belo Horizonte: Escola de Ciência da Informação da UFMG, 2003. 1 CD-ROM.

CHANG, K.C. Setlement Archaeology. California, Palo Alto. 1968.

CHIBENI, S. S. A Inferência Abdutiva e o Realismo Científico. Cadernos de História e Filosofia da Ciência, série 3, 6 (1): 45-73, 1996.

CHMYZ, I 1986 A Formação de Sambaquis em Período Histórico no Estado do Paraná. Arqueologia. Curitiba: CEPA/UFPR, 5:103-111.

CHMYZ, I. 1976 A ocupação do litoral dos Estados do Paraná e Santa Catarina por povos ceramistas. Estudos Brasileiros, 1(1):79-143. Curitiba, PR.

CHMYZ, I. A ocorrência de sítio arqueológico com pontas-de-projétil no Litoral Paranaense. Nota Prévia sobre o sítio PRP31: Ribeirão, In: Anais da Academia Brasileira de Ciências. Rio de Janeiro: n. 47, p. 81-89, 1975. Suplemento

CHMYZ, I. A tradição Tupiguarani no litoral do Estado do Paraná. Revista do Círculo de Estudos Bandeirantes. Curitba, n. 16, setembro, 2002. p. 71-95.

CHMYZ, I. SGANZERLA, E. M.; CHMYZ, J.C.G. Novas contribuições para o estudo do Sambaqui de Mantinhos, no Estado do Paraná. Arqueologia, Número especial, Curitiba, v. 1, p. 1-55, 2003.

CLARKE, D. L. Archaeology: the loss of innocence. Antiquity, n. 46, p. 6-18, 1973.

CLARKE, D. L. Arqueología Analítica. ediciones bellaterra, s.a., Barcelona 1984 (1968). Segunda edição.

CLARKE, D. L. Review of: explanation in archaeology. Antiquity, n. 46 pp.237-39.1972

COELHO NETTO, J. T. Semiótica, informação e comunicação. Debates. Semiótica. Editora Perspectiva. São Paulo, SP, .2003. 217.

COLANGELO, A. C. Carta de Feições Mínimas, XIV Congresso Brasileiro de Cartografia, p 375380. Gramado, RS. 1989

COLANGELO, A. C. Modelo de Feições Mínimas, ou das Unidades Elementares de Relevo: um suporte cartográfico para mapeamentos geoecológicos. Revista do Departamento de Geografia, 10:29-40. USP/FFLCH. São Paulo, SP. 1996.

COLANGELO, A. C. Movimentos de massa e evolução geomorfoógica das vertentes marginais no lago de barragem do Paraibuna - SP, 1990. Dissertação - Mestrado em Geografia (Geografia Física).Universidade de São Paulo, USP, Brasil, 1990.

COLLINS, M. B. The Sources of Bias in Processual Data: Na Appraisal. In Sampling in archaeology, edite by jJames W. Mueller, pp. 26-32. University of Arizona Press, Tucson. 1975.

COPEL (Companhia Paranaense de Energia Elétrica). Estudo de viabilidade Técnica Econômica e Ambiental - Usina Hidrelétrica Guaratuba, Bacia do Rio Cubatão, PR. Curitiba, volumes I e II, 1997.

CORREIA, J. C. F. Duas concepções de informação: Shannon e Weaver e Wiener. Novembro 15, 2005 http://a-informacao.blogspot.com/2005/11/duas-concepes-de-informao-shannon-e.html

COUTO, C. DE P. O pleistoceno sul-americano e as migrações humanas pré-históricas. In: Préhistória Brasileira. São Paulo, Instituto de Pré-História da Universidade de São Paulo, 1968., p.3-39.

COWGILL, G. L. Some Sambpling and Reliability Problems in archaeology. In Archéologie et calculateurs: problèmes semiologicques et mathématiques. colloques Internationaux du Centre 
National de la Recherche Scientifique. Editions du Centre National de la Recherche Scientifique, Paris, 1970. pp. 161-175

CRUZ, O. A Serra do Mar e o litoral na área de Caraguatatuba. São Paulo: Instituto da Faculdade de Filosofia, Universidade de São Paulo. 181p. (Série Teses e Monografias, 11). 1974.

CRUZ, O; COUTINHO, P.N.; DUARTE, G.M.; GOMES, A.M.B. Brazil. In: bird, E.CF. \& Schwartz, M.L. (eds). The world's coastline. New York: Van Nostrand Reinhold Co. p.85-91. 1985.

DANIELS, S. G. H. Research design models. In Models in archaeology, edited by D.L.Clarke. London: Methyen. Pp. 201-229.

DIAS JR., O. A tradição Itaipu, costa central do Brasil. In: Meggers, B. (ed). Prehistoria Sudamericana - Nuevas perspectivas, Taraxacum Washington, Chile, 1992. pp.161-176

DIAS Jr., O. Resultados preliminares do segundo ano de Pesquisas no Estado do Rio de Janeiro. In: Programa Nacional de Pesquisas Arqueológicas. Museu Paraense Emílio Goeldi, Belém, pp. 119129 (Pubs. Avulsas, 10) 1969.

DIAS JR., O.; CARVALHO, E. Tradição Itaipu (RJ) Discussão de tópicos a proposta de um modelo teórico. Revista do CEPA, 17(20), Santa Cruz do Sul:157-166. 1990

DUNNEL, R.C. Methodological Issues in American Artifact Classification. Advances in Archaeological Method and Theory; vol. 9; pp. 149-207; 1986.

DUNNELL, R. C; DANCEY, W. S. The Siteless Survey: A Regional Scale Data Collection Strategy. In: SCHIFFER, M. (ed.). Advances in Archaeological Method and Theory, v. 6, p. 267-287, 1983.

DUNNELL, R.C. Systematics in Prehistory. New York: The Free Press, 1971, 214pp.

DUTRA, L.H. de A. Introdução à teoria da ciência. $2^{\circ}$ edição. Florianópolis: Editora da UFSC, 2003. 150p.

EMPERAIRE, J. \& LAMING, A. 1954/56 Les sambaquis de la côte méridionale du Brésil, campagnes de fouilles. Journal Société des Americanistes, 45:5-163. NS, Paris.

EMPERAIRE, J. \& LAMING, A. Les sambaquis de la côte méridionale du Brésil, campagnes de fouilles. Journal Société des Americanistes. NS, Paris, n.45, p. 5-163, 1954/56.

EVANS, C; MEGGERS, B. J. Guia para prospecção arqueológica no Brasil. Belém: Museu Paraense Emílio Goeldi, 1965.

FAUGHT, M.K.; DONOGHUE, J.F. Marine Inundated Archaeological Sites and Paleofluvial Systems: Examples from a Karst-Controlled Continental Shelf Setting in Apalachee Bay, Northeastern Gulf of Mexico. Geoarchaeology: An International Journal, 12(5):417-458. 1997.

FERNANDES R. M. S.; AZEVEDO, T S. Teoria da Informação e suas Aplicações em Compressão e Aleatoriedade. Projeto do curso de Estatística e Probabilidade. Programa de Engenharia de Sistemas e Computação (PESC) do Instituto Alberto Luiz Coimbra de Pós-graduação e Pesquisa de Engenharia (COPPE) da UFRJ. Rio de Janeiro, maio de 2006. Disponível no site: www.ravel.ufrj.br/arquivosPublicacoes/cos702_Rafael_Tiago.pdf

FERNANDES, J. L. Os sepultamentos do sambaqui de Matinhos. In: XXXI Congresso Internacional de Americanistas São Paulo: Ed. Anhembi, v.2, 1955. p. 579-602,

FERNANDES, J.L. 1955 Os sepultamentos do sambaqui de Matinhos. In: CONGRESSO INTERNACIONAL DE AMERICANISTAS (31, 1954, São Paulo). Anais..., p.579-602. São Paulo, SP

FIDALGO, A.. Os Quadros da Incerteza. Uma abordagem aos conceitos de Informação e Redundância.. In: José Manuel Santos e João Carlos Correia (orgs). Teorias da comunicação, Covilhã: Universidade da Beira Interior, 2004, p.15-28.

FISH, P. Pesquisa de Arqueologia Regional em Ambiente Florestal. A Represa Wallace: Um Estudo de Caso. In: Workshop de Métodos Arqueológicos e Gerenciamento de Bens Culturais. Florianópolis: 1993.

FOGAÇA, E. A tradição itaparica e as indústrias líticas pré-cerâmicas da Lapa do Boquete (Minas Gerais - Brasil). Revista do Museu de Arqueologia e Etnologia, $n^{\circ}$ 5. São Paulo: USP. 1995. p. 145-158.

FRODEMAM. R. L. Geological reasoning: geology as an interpretive and historical science. Geol. Soc. Am. Bull., v.107, n.8, p.960-968 1995. 
FÚLFARO, V.J. et al. Escorregamentos de Caraguatatuba: expressão atual e registro na coluna sedimentar da planície costeira adjacente. In: CONGRESSO BRASILEIRO DE GEOLOGIA DE ENGENHARIA, 1976. Anais... Rio de Janeiro: ABGE, 1976. v. 2, p. 341-350.

GALLAY, Alain. L'Archeologie Demain. Paris, Pierre Belfont, 1986

GÁNDARA, M.. "La vieja nueva arqueología": Boletín de Antropología Americana 2 y 3. 1981 p. 59-97 (primeira parte) p.99-160 (segunda parte).

GARCIA dos SANTOS, L. Predação high tech, biodiversidade e erosão cultural: O caso do Brasil. (text not edited) consulta no site http://www.ces.uc.pt/emancipa/research/pt/ft/biosocio.html em 20/02/2007.

GASPAR, M. D. Sambaqui: Arqueologia do litoral brasileiro. Rio de Janeiro: Jorge Zahar, 89p.2000.

GASPAR, M. D.; Blasis, Paulo De. Construção de Sambaqui" Anais da VI Reunião Científica da Sociedade de Arqueologia Brasileira, 1992

GASPAR, M.D. Análise de datações radiocarbônicas dos sítios de pescadores, coletores e caçadores. Bol. do Museu Paraense Emílio Goeldi - Ciência da Terra. Belém: MPEG, 8:81-91, 1996.

GASPAR, M.D. Aspectos da organização social de um grupo pescador-coletor-caçador: Região compreendida entre a llha Grande e o delta do Paraíba do Sul. Rio de Janeiro. Tese de Doutoramento em Arqueologia. USP. São Paulo, 1991.

GLADFELTER, B. G. Developments and Directions in Geoarchaeology. Advances in Archaeological Method and Theory, n.4, p. 343-364, 1981.

GLADFELTER, B. G. Geoarchaeology: the geomorphologist and Archaeology. American Antiquity, v.42, n. 4, p. 519-538, 1977.

GORDON, J. \& SHORTLIFFE, E. H. The Dempster-Shafer Theory of Evidence. In: Rule-based expert systems. New York, Addison-Wesley, 1984.p.272-29, 1984.

GOULD, Richard A. Recovering the Past. University of New Mexico Press, 1990.

GOULD, Stephen Jay. Lance de dados. A idéia de evolução de Platão a Darwin. Tradução Sergio Moraes Rego. Rio de Janeiro: Record, 2001.

GRUZA, V.V. ROMANOVSKIY, S.I. - 1985 - The principle of actualism and logic in Understanding the Geologic Past. Int.Geol. Rev. 17 (2).

GUCCIONE. M.J; SIERZCHULA M.C.; LAFFERTY III, R.H.; KELLEY D. Site Preservation along an Active Meandering and Avulsing River: The Red River, Arkansas. Geoarchaeology: An International Journal, Vol. 13, n.5, 475-500.1998;

GUIMARÃES, M.B.C. A ocupação da Região dos Lagos, RJ: Sistema de assentamento e relações intersocietais entre grupos sambaquiandos e grupos ceramistas tupinambá e da tradição Una. 2007. 355f. Tese (Doutorado) - Museu de Arqueologia e Etnologia da Universidade de São Paulo, São Paulo. 2007.

HASSAN, F. A. Geoarchaeology: The Geologist and Archaeology. American Antiquity, v.44, n. 2, p. 267-270, 1979.

HASSAN, F. A. Sediments in Archaeology: Methods and Implications for Palaeoenvironmental and Cultural Analysis. Journal of Field Archaeology, n. 5, p.197-213, 1978.

HURT, W.R.; BLASI O. O sambaqui do Macedo (A.52.B), Paraná. Arqueologia, Curitiba: Cons. Pesq. UFPR, n.2, p.1-98, 1960.

IPT (Instituto de Pesquisas Tecnológicas). Análise de risco de processos de movimentos de massa e estudos para determinação de cota máxima de inundação para subsidiar a escolha entre as alternativas locacionais $3^{\mathrm{a}}, 4^{\mathrm{a}}$ e $4 \mathrm{~B}$ da Unidade de Tratamento de Gás do gasoduto Mexilhão, Caraguatatuba, SP. Relatório Técnico n.90 643 - 205. Novembro de 2006. (arquivo digital para consulta)

KAHNEMAN, D. \& TVERSKY, A. Judgement under uncertainty. Cambridge University Press, Cambridge. 280p. 
KANT, I. Critica da Razão Pura. Tradução de Valeriao Rohden e Udo Baldur Moosburger. Serie Os Pensadores. São Paulo: Nova Cultural (ed), 1999.

KASHIMOTO E. M. O uso de variáveis ambientais na detecção e resgate de bens pré-históricos em áreas arqueológicamente pouco conhecidas. In: CALDARELLI, S. B. (org.) Atas do Simpósio sobre Política Nacional do Meio Ambiente e Patrimônio Cultural, 1996. Goiânia: Instituto Goiano de PréHistória e Antropologia, 1997. p. 91-94.

KEEGAN, W.F \& MITCHEL, S.W. Possible allochthonous Lucayan Arawak artifact distributions, Bahama Islands. J. Field Arch. 13:255-258. 1986

KELLOGG, D. C. How Has Coastal Erosion Affected the Prehistoric Settlement Pattern of the Boothbay Region of Maine? Geoarchaeology: An international Journal, Vol.10, n.1, pp. 65-83. 1995.

KERN, Arno A. Pescadores-coletores pré-históricos do litoral norte do Rio Grande do Sul. In: Documentos. São Leopoldo. Instituto Anchietano de Pesquisas, 1989.

KIPNIS, R. O uso de modelos preditivos para diagnosticar recursos arqueológicos em áreas a serem afetadas por empreendimentos de impacto ambiental. In: CALDARELLI, S. B. (org.) Atas do Simpósio sobre Política Nacional do Meio Ambiente e Patrimônio Cultural, 1996. Goiânia: Instituto Goiano de Pré-História e Antropologia, 1997. p. 34-40.

KIPNIS, R.; SCHEEL-YBERT, R. Arqueologia e Paleoambientes. In: Souza, Suguio; Oliveira; Oliveira (org). Quaternário do Brasil. ABEQUA: Ribeirão Preto: Holos Editora, 2005 (382p. il.) 2005, p. 343362.

KRAFT, J. C. ; BELKNAP, D. F.; KAYAN, I. Potentials of discovery of human occupation sites on the continental shelves and nearshore coastal zone. In: MASTERS, P. M.; FLEMMING, N. C.(Org). Quaternary coastlines and Marine Archaeology. New York: Academic Press, 1983. p. 87-120.

KRONE, R. Informações ethnográficas do Valle do Rio Ribeira do Iguape, de Esploração do Rio Ribeira do Iguape, 2n. Edição: 23-24. Comissão do Estado de São Paulo, 1914.

KUHN, T.S. The Structure of Scientific Revolutions. Chicago: University of Chicabo Press. 1970

LACTEC/CEHPAR,. EIA-Rima das Estações de Tratamento de Esgoto de Matinhos e Pontal do Paraná. Instituto de Tecnologia para o Desenvolvimento - LACTEC e Centro de Hidráulica e Hidrologia Professor Parigot de Souza - CEHPAR. Curitiba, 2001

LAKATOS, E.M; MARCONI, M.A. Metodologia Científica. 4 ed. São Paulo: Atlas, 2004.

LEONOV, G.P. - Historicism and Actualism in Geology - 1971 - Int. Geol. Rev. 13 (4)

LESSA Guilherme Camargo; ANGULO, Rodolfo José; Giannini, Paulo César Fonseca: Araújo, A.D. Stratigraphy and Holocene evolutiona of a regressive barrier Ins south brasil. Marine Geology, amsterdan, v.165, n.1-4, p.87-108, 2000.

LESSA, Guilherme Camargo; ANGULO, Rodolfo José. Oscillations Or Noto Oscillations, That Is The Question - Reply. Marine Geology, Amsterdan, v. 150, p. 189-196, 1998

LESSA, Guilherme Camargo; ANGULO, Rodolfo José. A proposed Model for the Stratigraphy and Evolution of the Paranaguá Coastal Plain - Paraná, Brazil. Anais do V Congresso da ABEQUA, 1995

LEWIS, R.B. Sea-Level Rise and Subsidence Effects on Gulf Coast Archaeological Site Distributions. American Antiquity, 65(3):525-541. 2000

LIMA, T. A. Em busca dos frutos do mar: os pescadores-coletores do litoral centro-sul do Brasil. Antes de Cabral: Arqueologia Brasileira II. Revista USP, São Paulo, n. 44, p. 270-327, dez./fev.1999/2000.

LIMA, T.A. Dos Mariscos aos Peixes: um Estudo Zooarqueológico da Mudança de subsistência na Pré-História do Rio de Janeiro. Tese (Doutoramento em Arqueologia) - Faculdade de Filosofia, Letras e Ciências Humanas / Universidade de São Paulo. 691p.

MACHADO, L. C. Resultados de pesquisas bioculturais em populações humanas pré-históricas do litoral do Rio de Janeiro. Boletim do Instituto de Arqueologia Brasileira (IAB), ํำ12, 2006.

MAGALHÃES, Gildo. Introdução à metodologia científica: caminhos da ciência e da tecnologia - São Paulo: Ática, 2005. 263p.

MALPICA, J. A.; MENA, J.; PEDRAZA, J.. Fusion de information com la teoría de la evidencia para la extracción de objetos cartográficos de imágenes aéreas. Actas del Seminario Anual de Automática, Electrónica Industrial e Instrumentación, 1, 511-514. 2002. 
MALPICA, J.A.; ALONSO, M.C.; SANZ, M.A. Dempster-Shafer Theory in geographic information systems: a survey. Expert Systems with Applications 32 (2007) 47-55

MARTIN, L. ; SUGUIO, K. . Excursion route along the coastline between the town of Cananéia (State of São Paulo) and Guaratiba outlet (State of Rio de Janeiro). In: 1978 International Symposium on Coastal Evolution in the Quaternary, 1978, São Paulo, SP. Special Publication, 1978. v. 2. p. 1-95.

MARTIN, L.; MORNER N. A.; FLEXOR, J.M.SUGUIO, K.; Fundamentos e reconstrução de antigos níveis marinhos do Quaternário. Universidade de São Paulo, Instituto de Geociências. Boletim IGUSP. Publicação Especial, n.4, 1986 161p São Paulo, SP.

MARTIN, L.; SUGUIO, K.; FLEXOR, J.M. 1984. Informações adicionais fornecidas pelos sambaquis na reconstrução de paleolinhas de praia quaternária: exemplos da costa do Brasil. Revista de PréHistória 6:128-47.

MARTIN, L.; SUGUIO, K.; FLEXOR, J.M. E AZEVEDO, A.E.G. 1988 Mapa geológico do quaternário costeiro dos estados do Paraná e Santa Catarina com texto explicativo, Boletim do DNPM, n.18, 40p.(série geologia básica). Brasília, DF.

MASI, M. A. N. De. Mobilidade de caçadores-coletores pré-históricos da costa Sulbrasileira. Ilha de Santa Catarina, um estudo de caso. In: Arno Alvarez Kern e Klaus Hilbert (org.) Arqueologia do Brasil Meridional. Anais da XI Reunião científica da Sociedade de arqueologia Brasileira - SAB. Coleção Arqueologia Virtual. Pontifícia Universidade Católica do Rio Grande do Sul, Porto Alegre, 2002.

MASTERS, P. M.; FLEMMING, N. C.(Org). Quaternary coastlines and Marine Archaeology. New York: Academic Press, 1983.

MENDES, J.C. Conheça a pré-história brasileira. São Paulo, Ed, da Universidade de São Paulo e Ed. Polígono. 172p. 1970.

MENDONÇA DE SOUZA, A. Pré-História fluminense. Rio de Janeiro, INEPAC/SEEC. 88p, 1981.

MENEZES, M.J. ANDREATTA, m. Os sepultamentos do sambaqui "B" do Guaraguaçu. In: O homem antigo na América. São Paulo: Inst. Pré-História USP, p.5-20, 1971.

MENEZES, M.J. Notas parciais sobre pesquisas realizadas no litoral do Paraná. Pesquisas: Antropologia. São Leopoldo, n.18, p. 53-64, 1968.

MENEZES, M.J. O sambaquis "B" do Guaraguaçu na paisagem litorânea do estado do Paraná. Tese de Livre-docência. Curitiba: UFPR, 1976.

MISSIAEN, T.; WARDELL, N.; DIX, J. Subsurface imaging and sediment characterisation in shallow water environments - Introduction to the special volume. Marine Geophysical Researches (2005) 26:83-85.

MORIN, E. A epistemologia da complexidade. In: Morin, E. \& Lê Moigne, J-L. A inteligência da complexidade. São Paulo: Peirópolis, 2000.

MORIN, E. O método 1: a natureza da natureza. Trad. llana Heineberg _ Porto Alegre : Sulina, 2005, 2 edição 480p.

MUEHE, D. O litoral Brasileiro e sua Compartimentação. In: Cunha, S.B.da; Guerra, A.J.T. (org). Geomorfologia do Brasil. Rio de Janeiro: Bertrand Brasil, 1998, pp.273-349

NEVES W.1984 AO meio ambiente e a definição de padrões de estabelecimento e subsistência de grupos caçadores-coletores: o caso da bacia do alto Guareí, SP. Revista de PréHistória, 6:175-180. USP. São Paulo, SP.

NEVES W. A. 1988 Paleogenética dos grupos pré-históricos do litoral sul do Brasil (Paraná e Santa Catarina) Pesquisas: Antropologia, 43:1-178. São Leopoldo, RS.

OLIVA, Alberto. Filosofia da Ciência. Rio de Janeiro: Jorge Zahar Ed., 2003.

OLIVEIRA, A. M. S. Depósitos tecnogênicos e assoreamento de reservatórios. Exemplo do reservatório de Capivara, rio Paranapanema, SP/PR. Tese (Doutorado) - Faculdade de Filosofia, Letras e Ciências Humanas, Departamento de Geografia, Universidade de São Paulo, São Paulo, 1994.

OLIVEIRA. M.S.C. Os Sambaquis da Planície Costeira de Joinville, Litoral Norte de Santa Catarina: Geologia, Paleogeografia e Conservação In Situ. 2000. 310 p. Dissertação (Mestrado 
em Geografia) - Departamento de Geociências, Universidade Federal de Santa Catarina, Florianópolis, 2000.

OLIVEIRA. M.S.C.; HORN FILHO, N. O. De Guaratuba a Babitonga: uma contribuição geológicoevolutiva ao estudo da espacialidade dos sambaquianos no litoral norte catarinense. Rev. Do Museu de Arqueologia e Etnologia, São Paulo, 11:55-75, 2001.

ORSSICH, A. \& ORSSICH, E. 1956 Stratigraphic Excavations in the Sambaqui of Araujo II, Paraná, Brasil. American Antiquity, 21(4):357-369.

ORSSICH, A. 1977a 1977b Observações arqueológicas em sambaquis. Cadernos de Arqueologia, 2:61-67. Museu de Arqueologia e Artes Populares de Paranaguá-UFPR. Paranaguá, PR.

ORSSICH, A. 1977a 1977c Traços de habitação nos sambaquis. Cadernos de Arqueologia, 2:69-72. Museu de Arqueologia e Artes Populares de Paranaguá-UFPR. Paranaguá, PR.

ORSSICH, A. 1977a O sambaqui do Araújo II, nota prévia. Cadernos de Arqueologia, 2:11-60. Museu de Arqueologia e Artes Populares de Paranaguá-UFPR. Paranaguá, PR.

ORSSICH, A. A propósito de sepulturas em sambaquis. Cadernos de Arqueologia, Museu de Arqueologia e Artes Populares de Paranaguá-UFPR, n.2, p.73-76, 1977d.

PACHECO, Leila M S. Informação e Contexto. Uma análise arqueológica. Dissertação (Mestrado) em Ciência da Informação da Universidade Federal do Rio de Janeiro. Rio de Janeiro, 1992. 116p.

PATRIK, L. D. Is there an archaeological record? In Advances in archaeological method an theory, Vol.8, edited by M.B. Schiffer, pp.27-62. Academic Press, Orlando. 1985.

PEIRCE, Charles Sanders. Semiótica e filosofia. São Paulo, Cultrix, Editora Universidade de São Paulo, 1975.

PENG, Y. \& REGIA, J.A. 1987; A Probabilistic causal Model for Diagnostic Problem Solving, IEEE Transactions on Systems Man and Cibernetics, Vol SMC-17

PEROTTO, F. S; VICARI R. M..Modelagem do conhecimento, sistemas especialistas e o projeto SEAMED. Revista eletrônica de Iniciação científica. SBC (Sociedade Brasileria de Computação).Porto Alegre, Ano 1 Vol 1 N.1, 2001. Site http://www.sbc.org.br/ visitado em 27/09/2006.

PINHEIRO, L. V. R.; LOUREIRO, J.M.M. Traçados e limites da ciência da informação. Ciência da Informação, vol. 24, n.1, 1995

POPPER, Karl. "Ciência: Conjecturas e Refutações". In Conjecturas e Refutações. $2^{\mathrm{a} e d . ~ B r a s i ́ l i a: ~}$ Editora da UnB, 1982.

POSSE, Z.C.S. 1978 A população pré-histórica do litoral paranaense, vista através de sambaquis. Dissertação de mestrado, Dep. Hist. UFPR, 175p. Curitiba, PR.

PROUS, A. 1992. Arqueologia Brasileira. Editora Universidade de Brasília, Brasília.

RAPP, G.; HILL, C. L. Geoarchaeology: The Earth-Science Approach to Archaeological Interpretation. New Haven: Yale University Press. 1998.

RAUTH, J.W. Escavação arqueológica no sambaqui do Guaraguaçu II, S.28.R, Paranaguá, Revista de Antropologia. Paranaguá, n.2, p.27-196, 1974b.

RAUTH, J.W. Nota prévia sobre a escavação arqueológica do sambaqui do rio Godo. In: PRONAPA, Resultado preliminares, 1968/69. Publicações Avulsas, Museu Paraense Emílio Goeldi, n.13 p.7598, 1969b.

RAUTH, J.W. Nota prévia sobre a escavação do rio Jacareí. In: PRONAPA, Resultado preliminares, 1969/70. Publicações Avulsas, Museu Paraense Emílio Goeldi, n.26 p.91-104, 1974a

RAUTH, J.W. Nota prévia sobre a escavação do rio São João. In: PRONAPA, Resultado preliminares, 1966/67. Publicações Avulsas Museu Paraense Emílio Goeldi, n.10 p.75-93, 1969a.

RAUTH, J.W. Nota prévia sobre a escavação do sambaqui do Porto Maurício. In: PRONAPA, Resultado preliminares, 1965/66. Publicações Avulsas Museu Paraense Emílio Goeldi, n.6, p.4754, 1967.

RAUTH, J.W. Nota prévia sobre o Sambaqui do Ramal. In: PRONAPA, Resultado preliminares, 1968/69. Publicações Avulsas, Museu Paraense Emílio Goeldi, n.15 p.115-128,1971. 
RAUTH, J.W. Notas arqueológicas sobre a formação de um sambaqui na llha das Cobras. Boletim do Dep. Antrop. da Faculdade de Paranaguá. Paranaguá, n.1, p.1-8, 1963.

RAUTH, J.W. O sambaqui de Saquarema (S.10.B-Paraná-Brasil). Boletim do Cons. Pesq. UFPR. Curitiba, 1962. 75p.

RAUTH, J.W. O sambaqui do Gomes, S. 11.B. Arqueologia, Curitiba: Cons. Pesq. UFPR n.4, 100p., 1968.

RICKLIS, R.A.; BLUM M.D. The Geoarchaeological Record of Holocene Sea Level Change and Human Occupation of the Texas Gulf Coast. Geoarchaeology, An International Journal, 12(4):287314. 1997

ROOSEVELT, A.C.; DOUGLAS, J.; BROWN, L. The Migrations and Adaptations of the First

ROSTIROLLA, S.P. Análise de incertezas em sistemas petrolíferos. Revista Brasileira de Geociências, 29(2):261-270, 1999.

ROSTIROLLA, S.P.; SOARES, P.C.; CHANG, H.K. Bayesian and Multivarite Metrhods Applied to Favorability Quantification in Recôncavo Basin and Ribeira Belt, Brazil. Nonrenewable Resources, Vol 7, No. 1, 1998.

SANTOS R. L.; OHATA, A. T.; CRUSCO, N.; QUINTANILHA, J. A. . A teoria da incerteza aplicada a classificação de imagens de satélite. In: XXI Congresso Brasileiro de Cartografia, 2003, Belo Horizonte. XXI Congresso Brasileiro de Cartografia, 2003.

SANTOS, M. dos. A problemática do levantamento arqueológico na Avaliação de Impacto Ambiental. Dissertação (Mestrado) - Faculdade de Filosofia, Letras e Ciências Humanaas, Universidade de São Paulo, Museu de Arqueologia e Etnologia, São Paulo, 2001.

SCHIFFER, M. B \& SKIBO, J. The Explanation of Artifact Variability. American Antiguity; 62(1): pp.2750; 1997.

SCHIFFER, M. B.; SULLIVAN, A. P.; KLINGER, T. C. The design of archaeological surveys. World Archaeology, v.10, n.1, p. 1-28, 1978.

SCHIFFER, M.B. Archaeological Context and Systemic Context. American Antiquity, 37:156-165. 1972

SCHIFFER, M.B. Behavioral archaeology. New York: Academic Press, 1976.

SCHIFFER, M.B. Formation Processes of the Archaeological Record. Salt Lake City: University of Utah Press, 1987. 428p.

SCHIFFER, M.B. The structure of archaeological theory. American Antiquity, 53 (3):461-485. 1983.

SCHMITZ, P. I. Áreas arqueológicas do Litoral e do Planalto do Brasil. Revi. do Museu de Arqueologia e Etnologia, S. Paulo, 1:3-20, 1991

SCHMITZ, P. I. Caçadores e coletores da Pré-História do Brasil. Instituto Anchietano de Pesquisas. UNISINOS. São Leopoldo, RS, 1984.

SCHMITZ, P. I. Contribuiciones a la prehistoria de Brasil. Pesquisas, Antropologia, v. 32, 1981.

SCIENTIA CONSULTORIA CIENTÍFICA. Diagnóstico Arqueológico e Histórico-Cultural da área da Unidade de Tratamento de Gás de Caraguatatuba (UTGCA), município de Caraguatatuba, SP. São Paulo, SCIENTIA, 2006.

SCIENTIA CONSULTORIA CIENTÍFICA. Levantamento Arqueológico Na Faixa de Depleção Do Reservatório da UHE Caconde, SP/MG. Scientia Consultoria Científica, Relatório Final. São Paulo, 2004. 139p.

SCIENTIA CONSULTORIA CIENTÍFICA. Projeto de Prospecção Arqueológica na área da Unidade de Tratamento de Gás de Caraguatatuba (UTGCA), município de Caraguatatuba - SP. São Paulo, SCIENTIA Consultoria, 2007.

SEARS, W.H. \& SULLIVAN, S.D. Bahamas prehistory. Am. Antiq. 43:3-25.1978.

SERRANO, A. The sambaquis of the brasilian coast. In: Steward, J. H. ed. Handbook of South American Indians. New York, Cooper Square. p.401-7. 1963.

SHANNON, C. e WEAVER, W. The mathematical theory of communication. Urbana, Univ. of Illinois Press, 1949. 
SILVA, A. de B. Sistemas de Informações Georeferenciadas. Conceitos e fundamentos. Campinas, SP: Editora da Unicamp, 1999. (coleção Livro-Texto).

SILVEIRA, J.D. Morfologia do litoral. In: Brasil, a terra e o homem. (Ed) A. de Azevedo, São Paulo, p.253-305. 1964.

SOARES, C.R.; ANGULO, R.J.; LESSA G.C. 1997 Roteiro da excursão ao litoral do Estado do Paraná: Morfodinâmica de ambientes atuais, evolução da planície durante o quaternário e problemas de erosão costeira. Publicação Especial n.2. VI Congresso da ABEQUA e Reunião sobre o Quaternário da América do Sul. Curitiba, PR.

SOARES, C.R.; BORZONE, C.A.; SOUZA, J.R.B. 1996Variações morfológicas e

SOARES, P. C. Incertezas no raciocínio geológico: um ensaio. Boletim Paranaense de Geociência, n.48, p.71-88. Curitiba: Editora da UFPR, 2000.

SOARES, P. C. SOARES, A.P.;FIORI, A.P. Raciocínio probabilístico aplicado à suscetibilidade de escorregamentos: um estudo de caso em Campo Largo, Paraná, Brasil. Boletim Paranaense de Geociências, n.51, p.59-76, 2002. Editora UFPR.

SOARES, P. C.; PERDONCINI, L. C. Incerteza e combinação de evidências: a questão do diamentes do rio Tibagi-PR (Brasil). Revista Brasileira de Geociências, 29(3):307-312, 1999.

SOUZA FILHO, Edvard E. de. Aspectos da Geologia e Estratigrafia dos depósitos sedimentares do rio Paraná entre Porto Primavera (MS) e Guaira (PR). Tese de doutoramento. Programa de PósGraduação em Geologia Sedimentar. Universidade de São Paulo, São Paulo, 1993.

SOUZA, Alfredo A.C.M. Pré-História Fluminense. Instituto Estadual do Patrimônio Cultural, Secretaria Estadual de Educação e Cultura. Rio de Janeiro, 1981, 102pp

SOUZA, C. R.de G. Considerações sobre os processos sedimentares quaternários e atuais na região de Caraguatatuba, litoral norte do Estado de São Paulo. 1990. 334 p. Dissertação (Mestrado) - Instituto Oceanográfico da USP, 1990. São Paulo, 1990. 334 p.

SOUZA, Maria Cristina de; ANGULO, Rodolfo José; PESSENDA, L.C. r. Evolução paleogeográfica da planície costeira de Itapoá, litoral norte de Santa Catarina. Revista Brasileira de Geociências, São Paulo, v.31, n.2, p. 223-230, 2001.

STEIN, J.K. Scale in archaeology, geosciences, and geoarchaeology. Geological Society of América. Special Paper, 283, 1993, in: Effects of Scale on archaeological and Geoscientific Perspectives, edited by Julie K. Steins and Angela R. Linse

SUGUIO, K; ANGULO, R.J. CARVALHO, A. M.; CORRÊA, I.C.S.; TOMAZELLI, L.J.; WILLWOCK, J.A.; VITAL, H. Paleoníveis do mar e paleolinhas de costa. In Souza et al (Ed.) Quaternário do Brasil. Ribeirão Preto, Holos Editora, 2005. p.114-129.

SULLIVAN, A. P. Inference and evidence in archaeology: a discussion of the conceptual problems. Advances in Archaeological Method and Theory, n. 1, p. 183-222, 1978.

TEIXEIRA, J. L. C. A malha paralela no Levantamento arqueológico regional: um estudo de caso na planície litorânea do Norte Capixaba - Brasil. 2002. 153p. Dissertação (Mestrado) Museu de Arqueologia e Etnologia. Faculdade de Filosofia, Letras e Ciências Humanas, Universidade de São Paulo, São Paulo. 2002.

TENÓRIO, M. C. . Identidade cultural e origem dos sambaquis. Revista do Museu de Arqueologia e Etnologia, v. 14, p. 169-178, 2004.

TENÓRIO. M. C. Estabilidade do grupos litorâneos pré-históricos: uma questão para ser discutida. In: Beltrão, M et al. (org). Arqueologia do Estado do Rio de Janeiro. Niterói: Arquivo Público do Estado do Rio de Janeiro, 1995. 136p. il.

TERRENATO, N.; AMMERMAN, A. J. Visibility and Site Recovery in the Cecina Valley Survey, Italy. Journal of Field Archaeology, v. 23, 1996.

TRIGGER, B. G. História do Pensamento Arqueológico. São Paulo: Odysseus Editora, 2004.

TRUJILLO FERRARI, A. Metodologia da ciência. 2. e 3. ed. Rio de Janeiro: Kennedy, 1974.

UCHÔA, J.Q.; PANONTIM, S. M.; NICOLETTI, M. DO C. Elementos da Teoria de Evidência de

Dempster-Shafer (Apresentação de Trabalho/Seminário). texto retirado do site http://www2.dc.ufscar.br/ carmo/relatorios/dempster.pdf em 05/10/2008.

VAN FRAASSEN, B.C. A imagem científica. São Paulo: Editora UNESP, 2007, pp 376. 
VAN FRAASSEN, B.C. The Scientific Image. Oxford, Clarendon Press, 1980.

VILLWOCK, J.A. A costa brasileira: geologia e evolução. Notas Técnicas, 7:38-49, CECA/IG/UFRGS, Porto Alegre, RS.1994.

WATERS, M.R. Principles of Geoarchaeology: a North American Perspective. Tucson: The University of Arizona Press, 1992. 399p.

WATERS, M.R.; KUEHN, D. The Geoarchaeology of place: The Effect of Geological Processes on the Preservation and Interpretation of the Archaeological Record. American Antiquity, v.61, n. 3, p. 483497, 1996.

WESTLEY, Kieran; DIX, Justin. Coastal environments and their role in prehistoric migrations. Journal of Maritime Archaeology, (2006) 1:9-28.

WILL , R.T.; CLARK, J.A..Stone artifact movement of impoundment shorelines: a case study from Maine. American Antiquity 61:499-519. 1996.

Wright, L.D.;Thom, B.G. Coastal depositional landforms: a morphodynamic approach. Progress in Physical Geography 1977 1: 412-459. 


\section{ANEXO 1}

TABELA 4:

\begin{tabular}{|c|c|c|c|c|c|c|c|c|c|}
\hline & $\mathrm{P}[\mathrm{C}]$ & $\mathrm{Pa}[\mathrm{C}]$ & $\mathrm{Pn}[\mathrm{C}]$ & $\mathrm{P}[\mathrm{C}]+\mathrm{Pa}[\mathrm{C}]$ & $\mathrm{C}$ & $\mathrm{P}[\mathrm{C}]$ & $\mathrm{Pa}[\mathrm{C}]$ & $\mathrm{Pn}[\mathrm{C}]$ & $\mathrm{P}[\mathrm{C}]+\mathrm{Pa}[\mathrm{C}]$ \\
\hline 1 & 0,2696 & 0 & 0,7304 & 0,2696 & 99 & 0,0454 & 0,2121 & 0,7425 & 0,2575 \\
\hline 2 & 0,0082 & 0,1515 & 0,8403 & 0,1597 & 100 & 0,0164 & 0,1515 & 0,8321 & 0,1679 \\
\hline 3 & 0,4041 & 0,0003 & 0,5956 & 0,4044 & 101 & 0,0428 & 0,1515 & 0,8057 & 0,1943 \\
\hline 4 & 0,0057 & 0,3333 & 0,661 & 0,339 & 102 & 0,0082 & 0,1515 & 0,8403 & 0,1597 \\
\hline 5 & 0,3172 & 0,1515 & 0,5313 & 0,4687 & 103 & 0,0027 & 0,1212 & 0,8761 & 0,1239 \\
\hline 6 & 0,0255 & 0,1515 & 0,823 & 0,177 & 104 & 0,0645 & 0 & 0,9355 & 0,0645 \\
\hline 7 & 0,1518 & 0,273 & 0,5752 & 0,4248 & 105 & 0,7433 & 0 & 0,2567 & 0,7433 \\
\hline 8 & 0,1187 & 0,273 & 0,6083 & 0,3917 & 106 & 0,7325 & 0,1515 & 0,116 & 0,884 \\
\hline 9 & 0,032 & 0,1215 & 0,8465 & 0,1535 & 107 & 0,674 & 0,1515 & 0,1745 & 0,8255 \\
\hline 10 & 0,0065 & 0,1515 & 0,842 & 0,158 & 108 & 0,4393 & 0 & 0,5607 & 0,4393 \\
\hline 11 & 0,2362 & 0 & 0,7638 & 0,2362 & 109 & 0,6236 & 0 & 0,3764 & 0,6236 \\
\hline 12 & 0,1687 & 0,1515 & 0,6798 & 0,3202 & 110 & 0,4393 & 0 & 0,5607 & 0,4393 \\
\hline 13 & 0,5741 & 0 & 0,4259 & 0,5741 & 111 & 0,5791 & 0 & 0,4209 & 0,5791 \\
\hline 14 & 0,2861 & 0,2124 & 0,5015 & 4985 & 112 & 0,911 & 0,1515 & $-0,0625$ & 1,0625 \\
\hline 15 & 0,0192 & 0 & 0,9808 & 0,0192 & 113 & 0,2272 & 0,1515 & 0,6213 & 0,3787 \\
\hline 16 & 0,0869 & 0,0909 & 0,8222 & 0,1778 & 114 & 876 & 0,6 & 0,1761 & 0,8239 \\
\hline 17 & 0,0017 & 0 & 0,9983 & 0,0017 & 115 & 0,6255 & 0,0303 & 0,3442 & 0,6558 \\
\hline 18 & 0,0401 & 0,1218 & 0,8381 & 0,1619 & 116 & 0,5012 & 0,2727 & 0,2261 & 0,7739 \\
\hline 19 & 0,1011 & 0 & 0,8989 & 0,1011 & 117 & 0,5361 & 0,1515 & 0,3124 & 0,6876 \\
\hline 20 & 0,2707 & 0,1515 & 0,5778 & 0,4222 & 118 & 0,6236 & 0 & 0,3764 & 0,6236 \\
\hline 21 & 0,232 & 0 & 0,768 & 232 & 119 & & 0,1212 & 0,2494 & 0,7506 \\
\hline 22 & 0,0092 & 0,2121 & 0,7787 & 0,2213 & 120 & 013 & 0,2121 & 0,0866 & 0,9134001 \\
\hline 23 & 0,0089 & 0,2121 & 0,779 & 0,221 & 121 & 0,5267 & 0,2121 & 0,2612 & 0,7388 \\
\hline 24 & 0,1844 & 0,3333 & 0,4823 & 0,5177 & 122 & 0,9671 & 0 & 0,0329 & 0,9671 \\
\hline 25 & 0,5023 & 0 & 0,4977 & 5023 & 123 & 651 & 0,1515 & 0,2834 & 0,7166 \\
\hline 26 & 0,0015 & 0,303 & 0,6955 & 0,3045 & 124 & 0,8054 & 0 & 0,1946 & 0,8054 \\
\hline 27 & 0,0768 & 0,3636 & 0,5596 & 4404 & 125 & 316 & 0,1515 & 0,7169 & 0,2831 \\
\hline 28 & 0,0017 & 0 & 0,9983 & 0017 & 126 & 242 & 0,2727 & 0,7031 & 0,2969 \\
\hline 29 & 0,0026 & 0 & 0,9974 & 0026 & 127 & 194 & 0 & 0,9806 & 0,0194 \\
\hline 30 & 0,0015 & 0 & 0,9985 & 0,0015 & 128 & 0,4898 & 0,303 & 0,2072 & 0,7928 \\
\hline 31 & 0,2477 & 0,3333 & 0,419 & 0,581 & 129 & 0,3734 & 0,0303 & 0,5963 & 0,4037 \\
\hline 32 & 0,0298 & 0,3636 & 0,6066 & 0,3934 & 130 & 643 & 0,1215 & 0,7142 & 0,2858 \\
\hline 33 & 0,7117 & 0,4848 & $-0,1965$ & 1965 & 131 & 0,4808 & 0 & 0,5192 & 0,4808 \\
\hline 34 & 0,1035 & 0 & 0,8965 & 1035 & 132 & 399 & 0 & 0,5601 & 0,4399 \\
\hline 35 & 0,8622 & 0 & 0,1378 & 0,8622 & 133 & 142 & 0,1818 & 0,404 & 0,596 \\
\hline 36 & 0,8902 & 0,1515 & $-0,0417$ & 1,0417 & 134 & 382 & 0 & 0,0918 & 0,9082 \\
\hline 37 & 0,0031 & 0 & 0,9969 & 0,0031 & 135 & 0,6898 & 0 & 0,3102 & 0,6898 \\
\hline 38 & 0,0026 & 0 & 0,9974 & 0,0026 & 136 & 0,5443 & 0,0303 & 0,4254 & 0,5746 \\
\hline 39 & 0,0017 & 0,1515 & 0,8468 & 0,1532 & 137 & 0,001 & 0 & 0,999 & 0,001 \\
\hline 40 & 0,0017 & 0,1515 & 0,8468 & 0,1532 & 138 & 0,0485 & 0,4848 & 0,4667 & 0,5333 \\
\hline 41 & 0,0027 & 0,1212 & 0,8761 & 0,1239 & 139 & 0,0055 & 0,2121 & 0,7824 & 0,2176 \\
\hline 42 & 0,0339 & 0,1515 & 0,8146 & 0,1854 & 140 & & 0,3333 & 0,0476 & 0,9524 \\
\hline 43 & 0,4043 & 0,3939 & 0,2018 & 0,7982 & 141 & 0,1729 & 0,0909 & 0,7362 & 0,2638 \\
\hline 44 & 0,4767 & 0,3636 & 0,1597 & 0,8403 & 142 & 0,5803 & 0 & 0,4197 & 0,5803 \\
\hline 45 & 0,1158 & 0 & 0,8842 & 0,1158 & 143 & 0,1624 & 0,303 & 0,5346 & 0,4654 \\
\hline 46 & 0,264 & 0,2424 & 0,4936 & 0,5064 & 144 & 0,7121 & 0 & 0,2879 & 0,7121 \\
\hline 47 & 0,0164 & 0,1515 & 0,8321 & 0,1679 & 145 & 0,5493 & 0 & 0,4507 & 0,5493 \\
\hline 48 & 0,4025 & 0 & 0,5975 & 0,4025 & 146 & 0,6294 & 0,1518 & 0,2188 & 0,7812001 \\
\hline 49 & 0,0026 & 0 & 0,9974 & 0,0026 & 147 & 0,8331 & 0,606 & $-0,4391$ & 1,4391 \\
\hline
\end{tabular}




\begin{tabular}{|c|c|c|c|c|c|c|c|c|c|}
\hline 50 & 0,0026 & 0 & 0,9974 & 0,0026 & 148 & 0,6236 & 0 & 0,3764 & 0,6236 \\
\hline 51 & 0,0026 & 0 & 0,9974 & 0,0026 & 149 & 0,007 & 0 & 0,993 & 0,007 \\
\hline 52 & 0,0207 & 0 & 0,9793 & 0,0207 & 150 & 0,0244 & 0,3636 & 0,612 & 0,388 \\
\hline 53 & 0,0593 & 0 & 0,9407 & 0,0593 & 151 & 0,0186 & 0,5157 & 0,4657 & 0,5343 \\
\hline 54 & 0,5723 & 0,1515 & 0,2762 & 0,7238 & 152 & 0,6147 & 0,3636 & 0,0217 & 0,9783 \\
\hline 55 & 0,7524 & 0,0606 & 0,187 & 0,813 & 153 & 0,0216 & 0,1212 & 0,8572 & 0,1428 \\
\hline 56 & 0,1876 & 0,303 & 0,5094 & 0,4906 & 154 & 0,0142 & 0,1515 & 0,8343 & 0,1657 \\
\hline 57 & 0,1888 & 0,1515 & 0,6597 & 0,3403 & 155 & 0,0142 & 0,1515 & 0,8343 & 0,1657 \\
\hline 58 & 0,5372 & 0,1515 & 0,3113 & 0,6887 & 156 & 0,4501 & 0,0303 & 0,5196 & 0,4804 \\
\hline 59 & 0,022 & 0 & 0,978 & 0,022 & 157 & 0,4595 & 0,1515 & 0,389 & 0,611 \\
\hline 60 & 0,1378 & 0,2727 & 0,5895 & 0,4105 & 158 & 0,2536 & 0 & 0,7464 & 0,2536 \\
\hline 61 & 0,0015 & 0 & 0,9985 & 0,0015 & 159 & 0,1014 & 0,3636 & 0,535 & 0,465 \\
\hline 62 & 0,0017 & 0,1515 & 0,8468 & 0,1532 & 160 & 0,1755 & 0,1515 & 0,673 & 0,327 \\
\hline 63 & 0,2757 & 0,3939 & 0,3304 & 0,6696 & 161 & 0,0302 & 0,1515 & 0,8183 & 0,1817 \\
\hline 64 & 0,0194 & 0 & 0,9806 & 0,0194 & 162 & 0,0154 & 0 & 0,9846 & 0,0154 \\
\hline 65 & 0,8525 & 0 & 0,1475 & 0,8525 & 163 & 0,4302 & 0,5151 & 0,0547 & 0,9453 \\
\hline 66 & 0,0922 & 0,1212 & 0,7866 & 0,2134 & 164 & 0,0463 & 0,0909 & 0,8628 & 0,1372 \\
\hline 67 & 0,3601 & 0,1515 & 0,4884 & 0,5116 & 165 & 0,0195 & 0,0909 & 0,8896 & 0,1104 \\
\hline 68 & 0,0021 & 0,1515 & 0,8464 & 0,1536 & 166 & 0,0305 & 0 & 0,9695 & 0,0305 \\
\hline 69 & 0,0021 & 0,1515 & 0,8464 & 0,1536 & 167 & 0,0305 & 0 & 0,9695 & 0,0305 \\
\hline 70 & 0,2069 & 0,1515 & 0,6416 & 0,3584 & 168 & 0,0305 & 0 & 0,9695 & 0,0305 \\
\hline 71 & 0,1544 & 0 & 0,8456 & 0,1544 & 169 & 0,0209 & 0,0303 & 0,9488 & 0,0512 \\
\hline 72 & 0,0231 & 0,1515 & 0,8254 & 0,1746 & 170 & 0,001 & 0 & 0,999 & 0,001 \\
\hline 73 & 0,0244 & 0,3636 & 0,612 & 0,388 & 171 & 0,1863 & 0 & 0,8137 & 0,1863 \\
\hline 74 & 0,1856 & 0 & 0,8144 & 0,1856 & 172 & 0,405 & 0 & 0,595 & 0,405 \\
\hline 75 & 0,0417 & 0 & 0,9583 & 0,0417 & 173 & 0,0154 & 0 & 0,9846 & 0,0154 \\
\hline 76 & 0,01 & 0,1212 & 0,8688 & 0,1312 & 174 & 0,0303 & 0 & 0,9697 & 0,0303 \\
\hline 77 & 0,0026 & 0 & 0,9974 & 0,0026 & 175 & 0,2565 & 0,4242 & 0,3193 & 0,6807 \\
\hline 78 & 0,0052 & 0,3939 & 0,6009 & 0,3991 & 176 & 0,7121 & 0 & 0,2879 & 0,7121 \\
\hline 79 & 0,0026 & 0 & 0,9974 & 0,0026 & 177 & 0,034 & 0,1515 & 0,8145 & 0,1855 \\
\hline 80 & 0,0026 & 0 & 0,9974 & 0,0026 & 178 & 0,0142 & 0,1515 & 0,8343 & 0,1657 \\
\hline 81 & 0,0017 & 0 & 0,9983 & 0,0017 & 179 & 0,0164 & 0,1515 & 0,8321 & 0,1679 \\
\hline 82 & 0,0269 & 0 & 0,9731 & 0,0269 & 180 & 0,0142 & 0,1515 & 0,8343 & 0,1657 \\
\hline 83 & 0,0057 & 0,2727 & 0,7216 & 0,2784 & 181 & 0,0208 & 0,2733 & 0,7059 & 0,2941 \\
\hline 84 & 0,1272 & 0 & 0,8728 & 0,1272 & 182 & 0,0197 & 0,1515 & 0,8288 & 0,1712 \\
\hline 85 & 0,2515 & 0,606 & 0,1425 & 0,8575 & 183 & 0,1377 & 0,1515 & 0,7108 & 0,2892 \\
\hline 86 & 0,4393 & 0 & 0,5607 & 0,4393 & 184 & 0,0741 & 0,1515 & 0,7744 & 0,2256 \\
\hline 87 & 0,0068 & 0,1515 & 0,8417 & 0,1583 & 185 & 0,05 & 0,1515 & 0,7985 & 0,2015 \\
\hline 88 & 0,0947 & 0 & 0,9053 & 0,0947 & 186 & 0,0026 & 0 & 0,9974 & 0,0026 \\
\hline 89 & 0,0026 & 0 & 0,9974 & 0,0026 & 187 & 0,4025 & 0 & 0,5975 & 0,4025 \\
\hline 90 & 0,0026 & 0 & 0,9974 & 0,0026 & 188 & 0,2247 & 0,0006 & 0,7747 & 0,2253 \\
\hline 91 & 0,0026 & 0 & 0,9974 & 0,0026 & 189 & 0,034 & 0,1515 & 0,8145 & 0,1855 \\
\hline 92 & 0,0012 & 0 & 0,9988 & 0,0012 & 190 & 0,0142 & 0,1515 & 0,8343 & 0,1657 \\
\hline 93 & 0,0463 & 0,2121 & 0,7416 & 0,2584 & 191 & 0,0142 & 0,1515 & 0,8343 & 0,1657 \\
\hline 94 & 0,0948 & 0 & 0,9052 & 0,0948 & 192 & 0,0142 & 0,1515 & 0,8343 & 0,1657 \\
\hline 95 & 0,8493 & 0,2121 & $-0,0614$ & 1,0614 & 193 & 0,0208 & 0,2733 & 0,7059 & 0,2941 \\
\hline 96 & 0,4399 & 0 & 0,5601 & 0,4399 & 194 & 0,0208 & 0,2733 & 0,7059 & 0,2941 \\
\hline 97 & 0,4945 & 0,1515 & 0,354 & 0,646 & 195 & 0,0013 & 0,1515 & 0,8472 & 0,1528 \\
\hline 98 & 0,5496 & 0,0909 & 0,3595 & 0,6405 & 196 & 0,5034 & 0 & 0,4966 & 0,5034 \\
\hline
\end{tabular}

